\title{
DINÅMICA SEDIMENTAR DO LITORAL NORTE PARANAENSE E EXTREMO SUL PAULISTA
}

\author{
Dissertação apresentada como requisito \\ parcial à obtenção do grau de Mestre. \\ Curso de Pós-Graduação em Geologia, \\ Departamento de Geologia, Universidade \\ Federal do Paraná. \\ Orientador: Prof. Rodolfo José Angulo \\ Co-orientadores: Prof. Moysés Gonzales Tessler \\ Prof. Paulo César Fonseca Giannini
}




\section{DINÂMICA SEDIMENTAR DO LITORAL NORTE PARANAENSE E EXTREMO SUL PAULISTA}

Dissertação aprovada como requisito parcial para obtenção do grau de Mestre no

Curso de Pós-Graduação em Geologia Ambiental da Universidade Federal do Paraná, pela Comissão formada pelos professores:

Orientador: Prof. Rodolfo José Angulo

Depto. de Geologia, UFPR

Prof. Lauro Júlio Calliari

Lab. Oceanografia Geológica-Depto. de Geociências, FURG

Prof. Michel Michaelovitch de Mahiques

Depto. Oceanografia Física-Inst. Oceanográfico, USP

Curitiba, 21 de março de 1997 


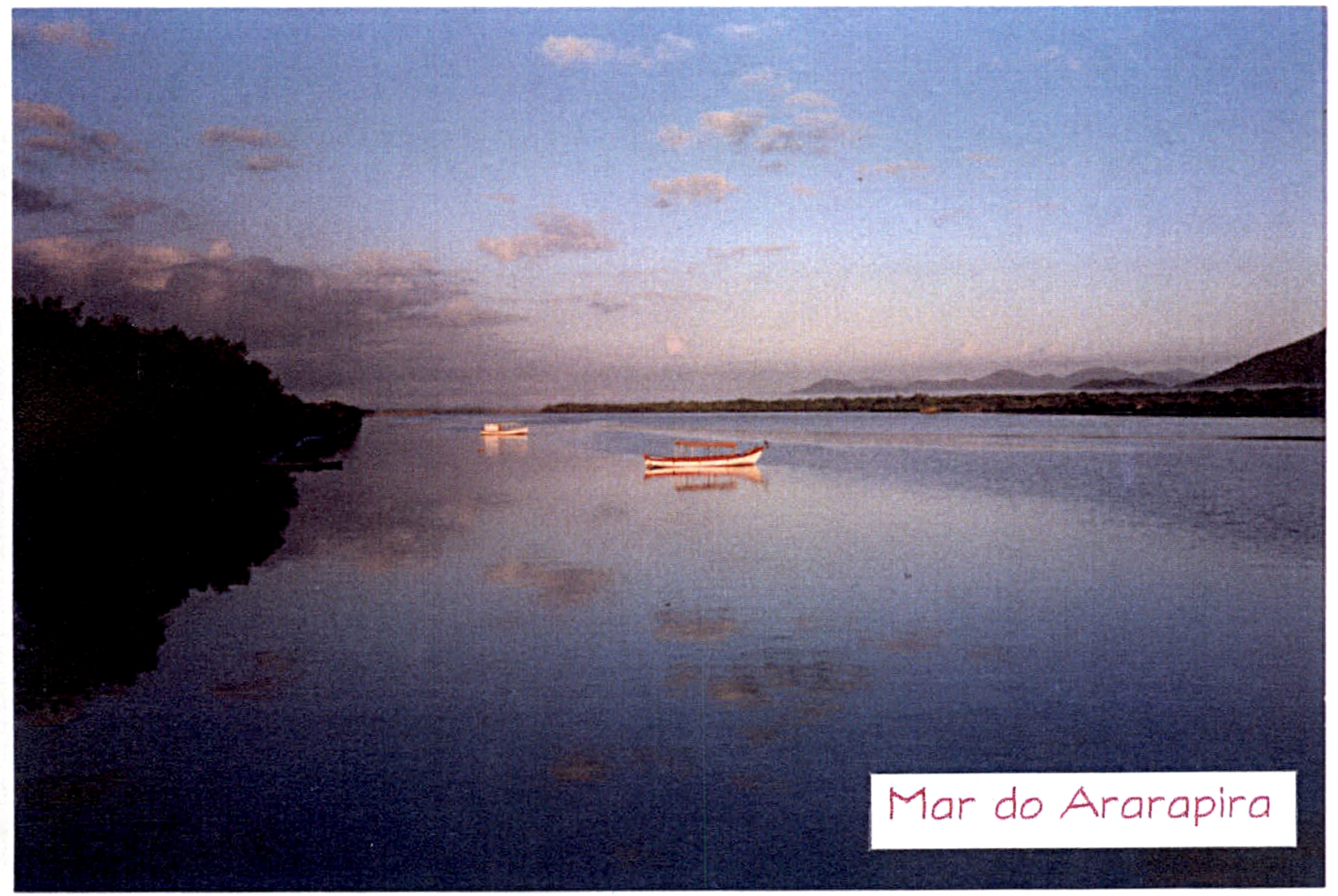

A Livia e Pedro, a raiz e o fruto. 


\section{AGRADECIMENTOS}

Ao orientador deste trabalho, Prof. Rodolfo José Angulo, agradeço a paciència, atenção e bom humor que acompanharam o desenvolvimento desta dissertação; e aos coorientadores Prof. Paulo César Fonseca Giannini pela correção minuciosa e Prof. Moysés Gonzales Tessler pelas valiosas observações. Agradeço também ao Prof. Armando Márcio Coimbra (DPE-IG-USP), co-orientador da parte inicial do trabalho.

Um agradecimento muito especial a Ricardo de Camargo pelo enorme auxilio e participação e também pelas discussões extremamente construtivas.

Às pessoas do Centro de Estudos do Mar-UFPR, pela participação em todas as etapas deste trabalho, em especial ao Prof. Carlos Roberto Soares pelo auxilio nas práticas de campo; a Márcia Salete Bernini e Sirlei Ghizi de Oliveira, do Laboratório de Oceanografia Geológica pelo auxilio com as análises granulométricas; aos barqueiros Sr. Carlito, Abraão e Josias, pelo grande companheirismo e aos voluntários Alfredo Araújo, Fernando Brandão Pilati, Eduardo Just Graeml, Cláudio Barcelos Silva, Jeferson Guimarães e Luciano Pohl, sem os quais teriam sido inviáveis e menos agradáveis os trabalhos de campo.

A Elaine Aparecida da Silva Sinfrônio, do Laboratório de Sedimentologia/DPE-IGUSP, agradeço o auxílio na separação de minerais pesados e a Jackeline Kogut, do Departamento de Geologia-UFPR, o auxílio na descrição e contagem destes. A Rita Parisi Conde do Laboratório de Informática/IG-USP, pela confecção dos slides para apresentação da dissertação.

Agradeço ao Centro de Estudos do Mar-UFPR pelo apoio logístico e em particular, ao Laboratório de Oceanografia Geológica/CEM-UFPR pela viabilização das jornadas de campo; ao Departamento de Gelogia-UFPR; ao Laboratório de Estatística-UFPR; ao IPARDES pelo empréstimo de fotos aéreas; ao Instituto de Geociências-USP pela concessão de utilização dos Laboratórios de Sedimentologia e de Microscopia e ao Departamento de Ciências Atmosféricas/IAG-USP pelas facilidades obtidas para a elaboração da versão final da dissertação.

Agradeço à CAPES pela concessão de Bolsa de Mestrado, e ao $\mathrm{CNPq}$ (processo $\mathbf{n}^{\circ}$ 522079/95-4) e ao Projeto Evolução Geológica e Mineralização-3, FINEP/PADCT-UFPR (nº $6591030300)$ pelo apoio financeiro. 


\section{SUMÁRIO}

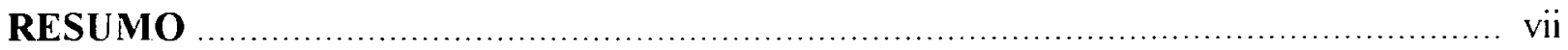

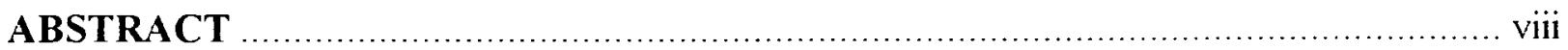

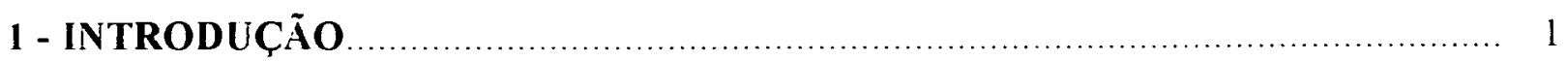

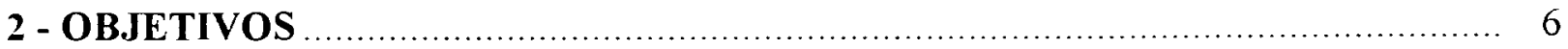

3 - CARACTERIZAÇÃO GERAL COM BASE EM TRABALHOS ANTERIORES .. 8

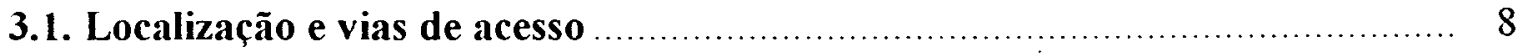

3.2. Áreas de Reserva Ambiental ........................................................ 10

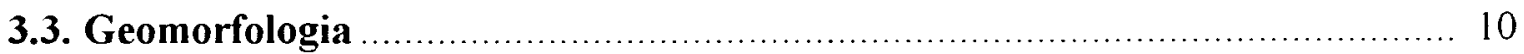

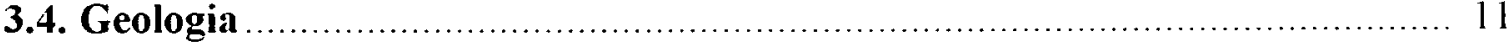

3.5. Ondas e correntes de deriva litorânea ............................................... 18

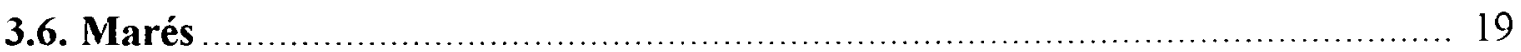

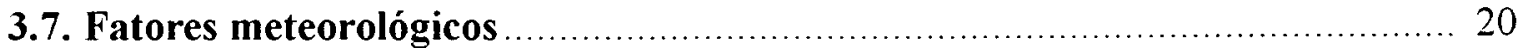

4 - MATERIAIS E MÉTODOS

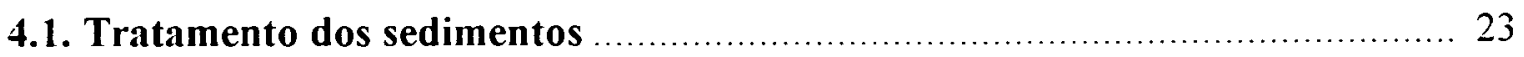

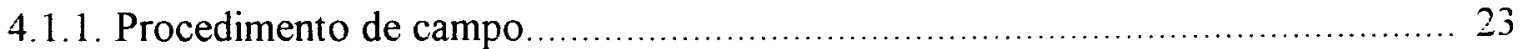

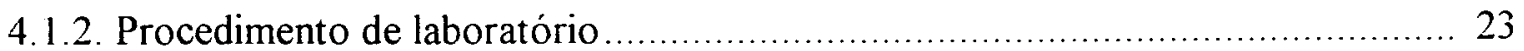

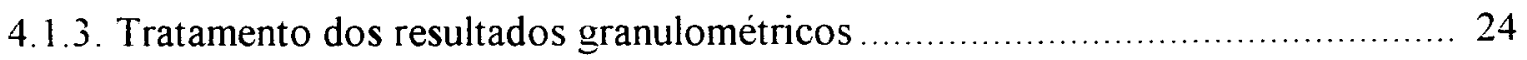

4.2. Dinâmica da Barra do Ararapira …................................................. 26

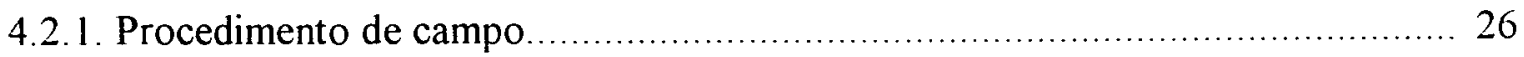

4.2.2. Tratamento dos resultados dos levantamentos topográficos ...................... 27

5 - TRABALHOS ANTERIORES SOBRE MIGRACÃO

LATERAL DE DESEMBOCADURAS LAGUNARES ............................... 29 


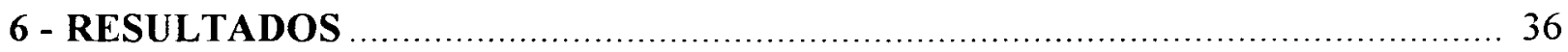

6.1. Distribuição dos parâmetros granulométricos ............................................. 36

6.2. Distribuição dos minerais pesados .......................................................... 42

6.3. Monitoramento das margens da Barra do Ararapira .................................. 46

6.3.1. Margem Ilha do Superagüi - Série S65E _............................................... 48

6.3.2. Margem Ilha do Superagüi - Série N45E …………………..................... 51

6.3.3. Margem Ilha do Superagüi - Série N05W …………................................. 53

6.3.4. Margem Ilha do Superagüi - Esporão de direção S62W …………………….... 55

6.3.5. Margem Ilha do Cardoso - Série N32W ................................................. 57

6.3.6. Margem Ilha do Cardoso - Série S52W .................................................. 59

6.3.7. Margem Illa do Cardoso - Série S22W ..................................................... 61

6.4. Considerações sobre a variação topográfica

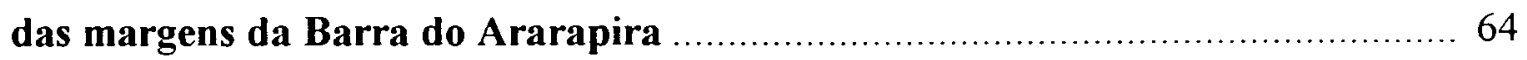

6.5. Monitoramento dos Estreitos no Esporão Arenoso do Ararapira .................. 66

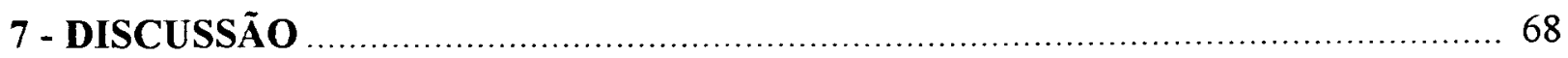

8 - CONCLUSÕES

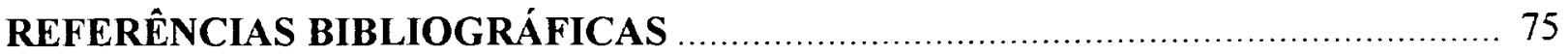

ANEXOS

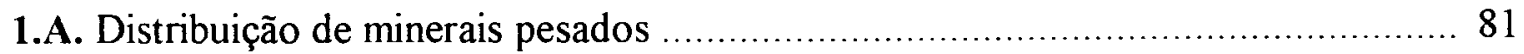

1.B. Localização dos pontos amostrados ............................................................ 83

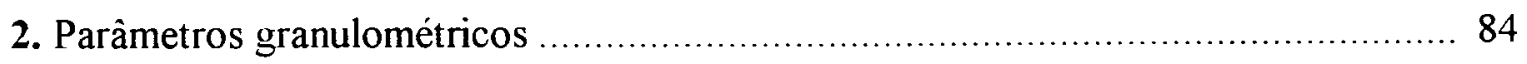

3. Análise estatistica da granulometria ……………….................................... 90

\section{PRANCHAS DE FOTOGRAFIAS}

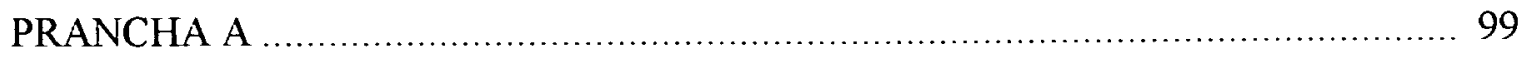

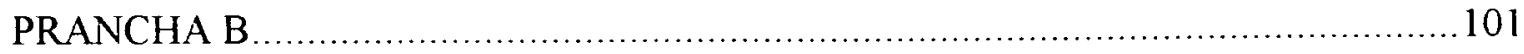

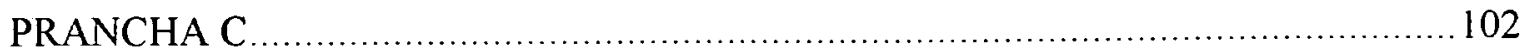




\section{RESUMO}

O estudo da dinâmica sedimentar do litoral norte paranaense e extremo sul paulista foi elaborado através dos seguintes métodos: análise granulométrica e mineralógica das areias das praias do Ararapira (SP), Deserta (PR) e da llha das Peças (PR), com o objetivo principal de identificar tendência na distribuição das características sedimentologicas; e o monitoramento da dinâmica da desembocadura lagunar do Ararapira (SP/PR), através do levantamento topográfico periódico das margens da desembocadura e acompanhamento da erosão nas margens do corpo lagunar do Ararapira. Esta desembocadura lagunar apresenta uma migração anômala, no sentido contrário ao da corrente de deriva litorànea longitudinal. $\mathrm{O}$ sentido predominante da corrente de deriva é para NE e está relacionado à passagem de frentes frias. A ausência prolongada deste efeito meteorológico causa variações temporárias no padrão de ondas, que induzem à inversão no sentido da corrente de deriva. Considerando-se esta inversão, são sugeridos dois modelos de circulação das correntes de maré e dos sedimentos, na desembocadura lagunar do Ararapira, que atuando alternadamente provocariam a migração desta no sentido inverso ao da corrente de deriva, ou seja para SW. Quando o sentido da deriva é para $\mathrm{NE}$, os processos que atuam na margem erosiva da desembocadura, durante a maré vazante, são semelhantes aos que ocorrem na margem côncava de um meandro, sendo as areias depositadas no delta de deriva litorânea. No entanto, quando ocorre a inversão no sentido da deriva, as areias que formam o delta de deriva litorânea são erodidas pela ação das ondas e depositadas, durante a maré enchente, na margem que está em processo de acresção. Estas areias seriam depositadas nesta margem em decorrência do bloqueio da deriva, pelo fluxo da corrente de maré vazante (efeito molhe hidráulico). As margens do corpo lagunar do Ararapira apresentam pontos de erosão, principalmente na margem localizada no esporão que separa o corpo lagunar do oceano, podendo com o avanço deste processo, ocorrer uma ruptura que originaria uma nova desembocadura. Este fato, juntamente com a progressiva elongação do corpo lagunar devido ao crescimento lateral do esporão do Ararapira, levaria à abertura de uma nova desembocadura mais a NE da atual e ao assoreamento de parte do corpo lagunar localizado entre as duas desembocaduras, a antiga e a recente. A inversão periódica do sentido da corrente de deriva litorânea longitudinal faz-se sentir também na distribuição dos parâmetros granulométricos das areias das praias. Este fato, aliado a um aporte constante de sedimentos às praias não permitem a identificação de um modelo conhecido de distribuição das características granulométricas. As três praias apresentaram, no entanto, uma melhora na seleção dos grãos e um incremento nos valores do índice ZTR no sentido NE, coincidente com o sentido da corrente de deriva predominante. 


\begin{abstract}
The study of sedimentary dynamics of north litoral of Paraná state and the extreme of south litoral of São Paulo state was done using the following methods: grain-size and mineralogical analysis of sandy samples from Ararapira (SP), Deserta (PR) and Ilha das Peças (PR) beaches, in order to identify trends in sedimentary characteristics distribution, as well as the monitoring of Ararapira's lagoonal mouth (SP/PR) dynamics, with periodic topographic data sets of mouth's margins and compaining erosion on internal lagoonal margins. This lagoonal mouth shows an anomalous migration, against the longshore current. The dominant direction of longshore current is NE and it's related to cold fronts passages. The long absense of this meteorological effect causes temporary changes on wave features, yielding to an inversion of longshore current. Considering this inversion, two circulation models of tidal currents and sediments are suggested to Ararapira's lagoonal mouth, which act alternately to induce the mouth migration on the opposite sense of longshore current, to SW. With NE longshore current, the acting processes on the erosive margin, during ebb tide, seem those ones on concave margins of meandering rivers, and the sand is deposited on the longshore drift delta. However, when longshore current inverts, the sand forming the longshore drift delta are eroded through wave action and deposited, during flood tides, on the growing margin. This sand is deposited at this margin because of drift blocking by ebb tide currents. The Ararapira's lagoonal margins show critical erosion portions, mainly at the internal margins of the sandy barrier that separates coastal lagoon and ocean, and this erosion process can let to new lagoonal mouth. This fact together with progressive elongation of the coastal lagoon caused by lateral sandy barrier growth, would let to the oppening of a new mouth toward NE of the actual one, and the filling of the coastal lagoon portion located between the two mouths. The periodic invertion of longshore current direction is also detected on grain-size parameters distribution along the beaches. This fact compained by a constant sediment source do not allow a pattern identification of grain-size distribution. The three beaches shown however a better grain sorting and an increase of ZTR index towards dominant longshore current direction.
\end{abstract}




\section{1 - INTRODUÇÃO}

No ambiente costeiro, marés, correntes geradas por marés, ondas, correntes geradas por ondas e ventos são os principais agentes naturais provocadores da retirada, transporte e deposição de sedimentos ao longo da costa. As amplitudes de maré determinam o montante de sedimentos disponiveis para entrar no sistema de transporte litoràneo (Taggart \& Schwartz, 1987). Em regiões com alta amplitude de maré, a energia é distribuída sobre uma faixa mais larga de litoral, sendo menos suscetível à erosão costeira do que regiões com pequena amplitude (Rosen, 1977 apud Taggart \& Schwartz, 1987). No entanto, quando há a coincidência de tempestades com a maré cheia de sizigia (marés meteorológicas ou storm surges) a erosão pode ser amplificada mesmo nas regiões com alta amplitude de maré (Calliari,L.J.; Lab. Oc. Geol/Dep. Geoc.-FURG, comunicação pessoal).

A incidência oblíqua das ondas à praia provoca a formação de uma corrente paralela à costa, denominada corrente de deriva litorânea longitudinal, responsável pelo principal meio de transporte de sedimentos ao longo da costa. O sentido da deriva pode ser inferido através de vários tipos de indicadores. São eles (Taggart \& Schwartz, 1987): largura, inclinação e forma das praias; morfologia de falésias marinhas; distribuição mineralógica e granulométrica dos sedimentos; distribuição de áreas de erosão e acresção, devido a alguma estrutura que interrompa a deriva; migração de canais e desenvolvimento de esporões.

Pode ocorrer a segmentação, ao longo da costa, da corrente de deriva litorânea, formando-se células de deriva com distintas direções (Stapor \& May, 1983). A indicação das células de deriva litorânea podem ser mascaradas por alguns fatores como, por exemplo: influxos constantes de sedimentos por escarpas sob processos erosivos ou descarga fluvial; variação no àngulo de aproximação das ondas; intervenção humana (Taggart \& Schwartz, 1987); intervalo de amostragem pequeno ou gradiente nos parâmetros granulométricos também pequeno (Gao \& Collins, 1991).

Os indicadores granulométricos funcionam seguindo-se o princípio de que os grãos mais grossos (mais pesados) somente são remobilizados por correntes geradas por ondas de alta energia, normalmente produzidas por tempestades, enquanto que os sedimentos mais finos (mais leves) podem ser transportados também por ondas de baixa energia que atuam constantemente na costa (McLaren, 1981) 
A distribuição dos tamanhos das partículas possibilita, segundo Gao \& Collins (1991): a) a identificação do ambiente deposicional do sedimento; b) a identificação do mecanismo predominante que controla o movimento dos sedimentos; c) o isolamento de modos de transporte de sedimentos e d) a compreensão dos processos de transporte e deposição (Vilas Boas \& Bittencourt, 1992). Os principais parâmetros granulométricos considerados como bons indicadores de tendências são o diâmetro médio (usualmente utilizando-se a escala phi), o desvio padrão (seleção) e a assimetria (McLaren, 1981).

Existe uma série de fatores que altera a mineralogia original de uma rocha exposta, como: intemperismo da rocha-fonte, intemperismo do material desprendido da rocha-fonte, abrasão mecânica durante o transporte, seleção hidráulica durante a deposição (que se reflete na tendência de cada mineral em concentrar-se numa determinada fração granulométrica), diagênese (Morton \& Smale, 1990) e ainda fenômenos pós-deposicionais como a dissolução intraestratal (Tessler, 1988). Durante o processo de destruição da rocha-fonte, alguns minerais vão sendo totalmente decompostos e alguns resistem até o depósito. Dentre estes encontramse os minerais pesados, que apresentam um alto grau de resistência ao intemperismo químico e físico. Eles são os acessórios das rochas de composição arenosa apresentando-se com concentração média entre $0,1 \%$ e $1 \%$ (Pettijohn, 1975).

A assembléia atual do depósito é uma função da composição da rocha-fonte e da estabilidade dos minerais. Portanto, espera-se que ao longo do trajeto entre a rocha-fonte e o depósito, seja possível a identificação de alguns ambientes e processos atuantes sobre os sedimentos, através das concentrações de minerais instáveis e estáveis, ou seja, através da maturidade mineralógica do sedimento.

A região em estudo abrange uma desembocadura lagunar, denominada Barra do Ararapira, que possui a peculiaridade de migrar no sentido oposto ao da deriva litorânea (Tessler, 1988). Por este fato, será dada ênfase ao estudo da dinâmica das margens desta desembocadura.

As desembocaduras lagunares são feições morfológicas, associadas a sistemas ilhasbarreira, que conectam corpos aquosos semi-confinados com o oceano, e separam lateralmente duas feições arenosas ou uma feição arenosa de um corpo rochoso próximo à costa (Reineck \& Singh, 1975). 
Generalizando, pode-se dizer que as desembocaduras lagunares são canais originados por ondas de tormenta, que rompem a barreira do sistema ilha-barreira; mantidos pelas correntes de maré e correntes fluviais, formadas pela descarga da bacia hidrográfica (Nichols \& Allen, 1981); que podem migrar ou sofrer estrangulamento e obstrução devido a ação das correntes de deriva litorânea (Isla, 1984). Caso ocorra a obstrução da desembocadura, a região lagunar, como todas as regiões semi-confinadas, tem tendência ao assoreamento (Besnard, 1950 apud Tessler \& Furtado, 1983).

A dinâmica das desembocaduras depende principalmente do regime hidráulico (correntes de maré, correntes de deriva litorànea e ondas), e secundariamente do suprimento de sedimentos e da litologia e topografia do substrato (Moslow, 1983). Estes fatores são responsáveis pela possivel migração lateral da desembocadura e feições associadas, e crescimento lateral da ilha-barreira. Esta migração lateral normalmente ocorre no sentido da corrente de deriva litorânea, pela deposição na margem a montante da desembocadura e erosão da margem a juzante (FitzGerald, 1988).

A gênese das desembocaduras lagunares, no Brasil, estaria associada às variações do nível médio do mar (Suguio \& Martin, 1978). A fase regressiva após a Transgressão Cananéia teria escavado os vales, que seriam, posteriormente, "afogados" pela Transgressão Santos, formando os corpos lagunares. A descarga de água fluvial nos corpos lagunares (Reddering, 1983), a vazão de água do corpo lagunar para o oceano (Nichols \& Allen, 1981) e a ação das ondas nas barreiras que protegem estes corpos, seriam os responsáveis pela abertura e manutenção das desembocaduras

A alternância das direções de fluxo da maré leva à formação de acumulações arenosas, nos pontos terminais da desembocadura, denominadas, respectivamente, de delta de maré enchente, no interior do corpo lagunar, e delta de maré vazante, na porção oceânica (Davis, 1994) (Fig.1.1).

O delta de maré vazante representa uma acumulação de sedimentos resultante da desaceleração da corrente de maré vazante; estes sedimentos são posteriormente retrabalhados pela ação das ondas durante os periodos de maré alta (Davis, 1994). Outro fator para a formação do delta de vazante é a obstrução dos sedimentos transportados pela corrente de deriva litorânea, pelo fluxo da maré vazante (efeito molhe hidráulico) (Tessler, M.G.; IO-USP, comunicação pessoal). 


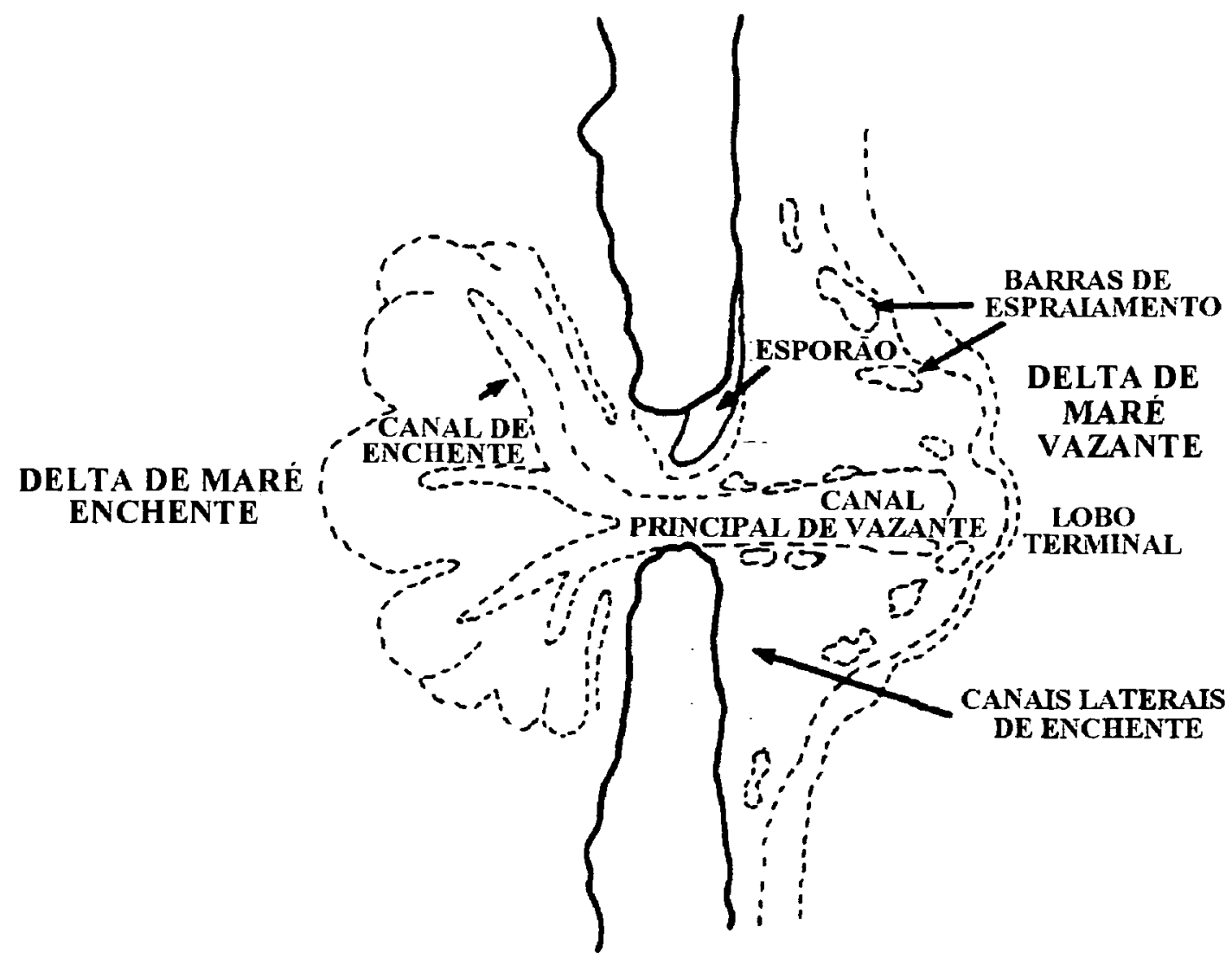

Figura 1.1. Representação esquemática de canal e deltas de maré e feições associadas (Davis, 1994).

O delta de maré enchente forma-se pela deposição das areias, quando ocorre a expansão da corrente de maré enchente após passar pela desembocadura adentro (Carter, 1988). Esta deposição ocorre sob a forma de uma plataforma de enchente, assumindo uma feição de rampa. No delta de maré enchente ocorrem ondulações orientadas no sentido do fluxo (Davis, 1994). A morfologia do delta de maré enchente pode ser o de uma parábola com concavidade voltada para o oceano, ou pode apresentar-se também, como vastos corpos arenosos lobados ou multilobados, em regiões de micromaré (Moslow \& Heron, 1994).

A desembocadura e, principalmente o delta de maré vazante, apresentam uma configuração diferente de acordo com o predomínio da ação das correntes de maré ou das ondas (e, como consequência, da corrente de deriva litorânea) (Fig.1.2). A corrente de deriva litorânea longitudinal, associadas a regimes de micro-maré, faz com que os canais sejam efềmeros na sua natureza mas responsáveis por grande parte do retrabalhamento da coluna sedimentar da ilha-barreira adjacente (Moslow \& Heron, 1994). 

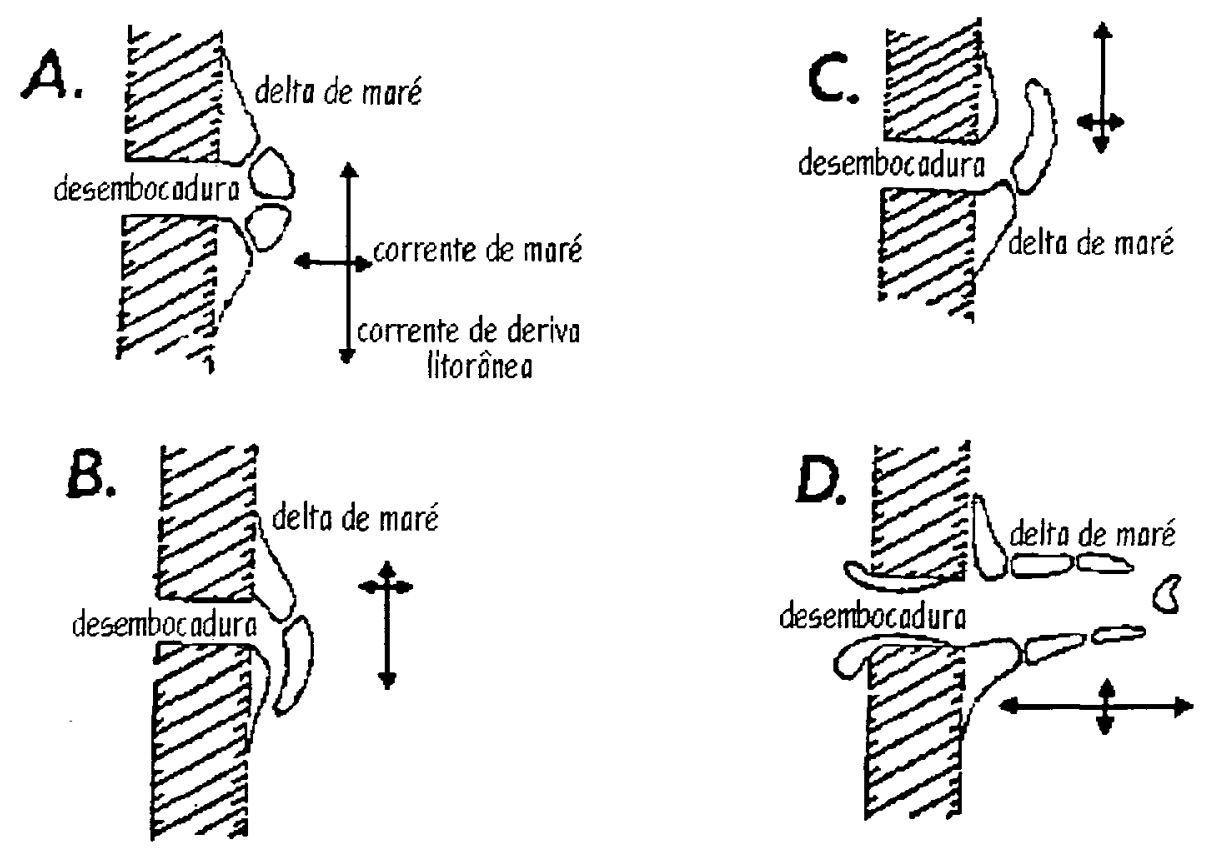

Figura 1.2. Variação na morfologia dos deltas de maré vazante (Oertel, 1985).

A zona litorànea provida de ambientes abrigados como lagunas, baías e estuários merece uma atenção especial pois geralmente constitui área de grande interesse para fins náuticos, turísticos, recreativos, pesqueiros e de obras de engenharia. É também, uma região rica em ecossistemas naturais. O estudo da migração das desembocaduras tem, além de um valor científico, grande aplicação no gerenciamento costeiro. Mudanças nas características da maré e no padrão de ondas, acompanhada da migração de canais e até de sua obstrução, produzem uma série de alterações no corpo aquoso atrás da barreira (Giese, 1988). 


\section{2- OBJETIVOS}

Por ser o ambiente litorâneo uma zona onde ocorre uma forte interação de processos continentais e costeiros, pretende-se com este trabalho contribuir para um melhor entendimento dos registros que a ação do mar causa na praia, através de um estudo de processos e fatores dominantes que controlam a dinâmica de praias e de desembocaduras lagunares.

Um dos objetivos deste estudo é a realização de uma caracterização sedimentológica das praias localizadas no extremo SW da Ilha do Cardoso (SP), e na porção oceânica das ilhas do Superagüi (PR) e das Peças (PR), através de análises granulométricas de amostras igualmente espaçadas ao longo das praias e da distribuição quantitativa e qualitativa de minerais pesados em amostras localizadas nos extremos e na porção mediana destas. Dispondo dos gradientes longitudinais nas características granulométricas e mineralógicas, buscar-se-á identificar eventuais tendências nas distribuições, a fim de correlacioná-las com as características hidrodinâmicas costeiras da região.

Outro objetivo deste trabalho é fazer o acompanhamento da dinâmica da Barra do Ararapira (SP/PR). Esta feição morfológica corresponde a uma desembocadura lagunar que apresenta uma migração anômala, no sentido contrário ao da deriva litorânea (Tessler, 1988).

A fim de se complementar o conjunto de informações durante o período de monitoramento, com o objetivo de se tentar estabelecer a relação entre a variação no ângulo de aproximação das ondas, e por conseguinte no sentido da corrente de deriva litorânea longitudinal à costa, e a distribuição de parâmetros granulométricos e minerais pesados ao longo das praias citadas, foi feito um levantamento das passagens de frentes frias, características dos ventos e fases da maré. Este levantamento proporcionou inferências do campo de ondas em determinadas situações, baseadas em um regime de ondas já observado anteriormente.

Foi também analisada a influência das características hidrológicas, como ondas e marés, e também a passagem de frentes frias, nos processos erosivos e acrescionais das margens da Barra do Ararapira a fim de se identificar o mecanismo de migração desta. 
A migração da Barra do Ararapira causa o crescimento lateral de uma das margens. Esta margem corresponde ao esporão do Ararapira, que assume uma configuração de barreira de um "sistema ilha-barreira" (Oertel, 1985). Foi acompanhada a evolução de alguns pontos deste esporão, que apresentam indícios de erosão na margem voltada para o corpo lagunar, localizada atrás da barreira.

O objetivo do acompanhamento dos processos erosivos nas margens do corpo lagunar foi o de apresentar uma estimativa do tempo necessário para a abertura de outra desembocadura, localizada na parte mais estreita do esporão do Ararapira e a consequiente obstrução da desembocadura atual, com base em modelos já existentes sobre este tipo de migração de desembocaduras. 


\section{3 - CARACTERIZAÇÃO GERAL COM BASE EM TRABALHOS ANTERIORES}

\subsection{Localização e vias de acesso}

A região de estudo abrange as seguintes feições costeiras (Fig.3.1.1): a praia localizada no extremo SW na Ilha do Cardoso (SP) que corresponde ao Esporão do Ararapira; o corpo lagunar localizado atrás do esporão, denominado Mar do Ararapira; a desembocadura do corpo lagunar, denominada Barra do Ararapira e as praias oceânicas das ilhas do Superagüi (Praia Deserta) e das Peças, localizadas no litoral norte paranaense.

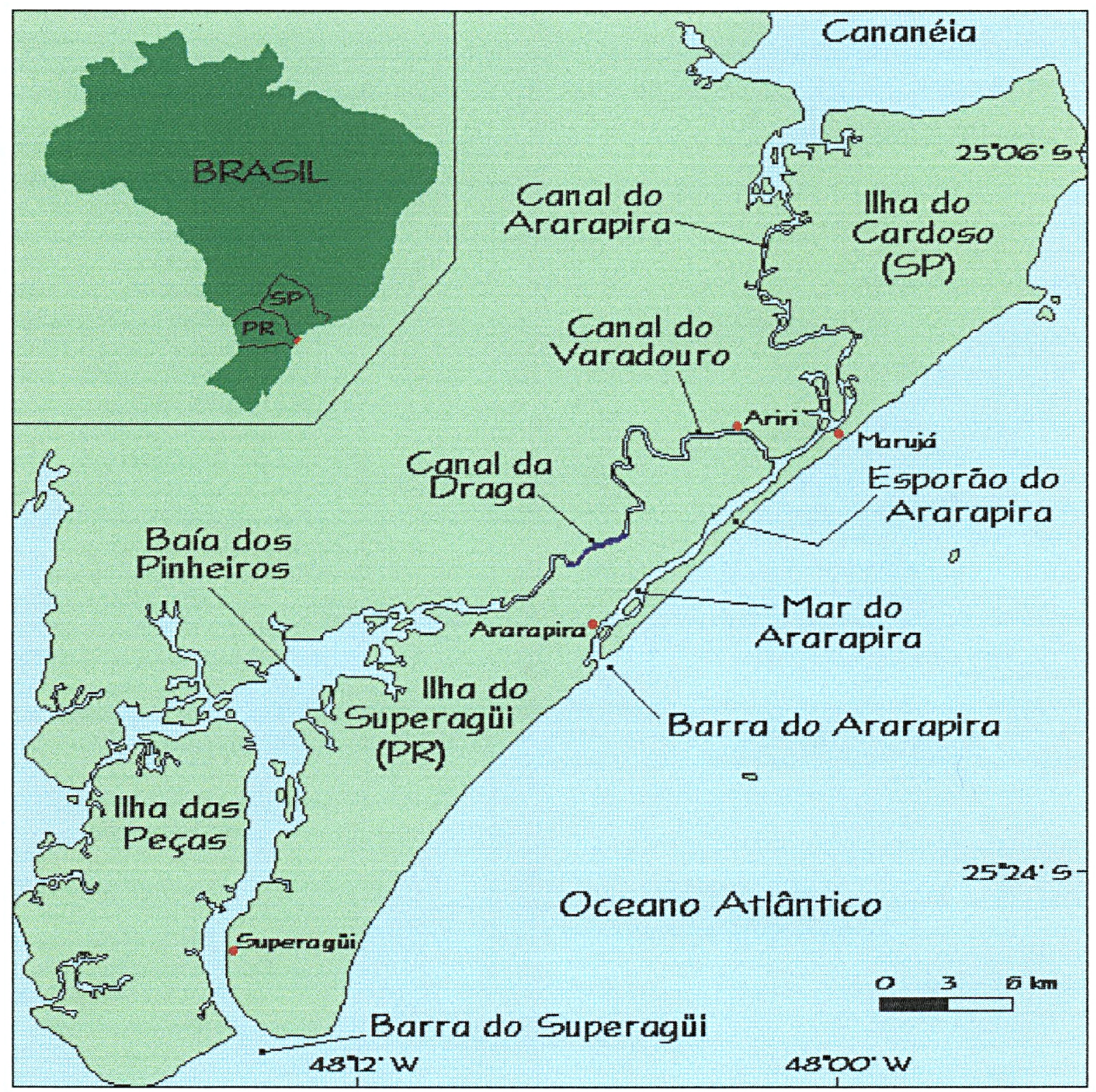

Figura 3.1.1. Mapa de localização da área em estudo 
O Mar do Ararapira é um corpo aquoso, alongado, levemente meandrante, com orientação SSW-NNE, paralelo à linha de costa atual (Foto 3.1.1-Prancha A), localizado entre a planicie costeira paranaense e sul paulista, que serve como divisor político costeiro entre os Estados de São Paulo e Paraná. A NW, é limitado pela planície costeira do Superagüi (PR), e a SE, pelo esporão arenoso do Ararapira (SP), o qual é denominado Enseada da Baleia, em sua porção oceânica.

O esporão do Ararapira constitui a porção meridional da Ilha do Cardoso e possui um comprimento em torno de $20 \mathrm{~km}$ e largura média de aproximadamente $400 \mathrm{~m}$, o que faz com que o conjunto se assemelhe a um "sistema ilha-barreira" (Figura 3.1.1).

O Mar do Ararapira comunica-se com o oceano através da Barra do Ararapira, localizada a SW (Foto 3.1.2-Prancha $\mathrm{A}$ ); com a região lagunar de Cananéia, através do Canal do Ararapira, e com o complexo estuarino da Baía dos Pinheiros, através do Canal do Varadouro. Este canal possui uma porção artificial com extensão aproximada de $3 \mathrm{~km}$, aberta na década de 50, denominado Canal da Draga.

A SW da Barra do Ararapira tem-se a planície costeira do Superagüi, que apresenta largura máxima de $5 \mathrm{~km}$ e uma praia com extensão aproximada de $30 \mathrm{~km}$, denominada Praia Deserta. A planície costeira do Superagüi passou a ser considerada como ilha após a abertura do Canal da Draga.

A Ilha das Peças localiza-se a SW da Ilha do Superagüi e é separada desta pelo Canal do Superagüi, apresentando uma praia oceânica com menos de $5 \mathrm{~km}$ de comprimento.

O Mar do Ararapira será aqui considerado como uma laguna costeira do tipo "Plataforma Interna Barrada", por se aproximar da classificação de Lankford (1977). De acordo com o autor, este tipo de laguna costeira deve apresentar as seguintes características: uma depressão na zona costeira, abaixo do nivel médio de maré alta, com permanente comunicação com o mar, mas protegida deste por uma barreira arenosa produzida por ondas/correntes; deve possuir também idade inferior a 5000 anos, orientação paralela à costa, batimetria rasa, e ocorrer em planícies costeiras de relevo suave.

O acesso à Barra do Ararapira se dá exclusivamente por meio de embarcação, preferencialmente pelo interior das baías e canais ou por mar aberto, somente em períodos de mar calmo. 
As localidades mais próximas são: I) Marujá (SP), localizado no esporão do Ararapira; II) Ariri (SP), nas margens do Canal do Varadouro e III) Cananëia (SP), a norte da Ilha do Cardoso. Os dois últimos locais permitem acesso até o trecho Curitiba-São Paulo da rodovia BR-116 e balsas da DERSA fazem a cabotagem para Marujá e outras vilas da região.

\section{2 Áreas de Reserva Ambiental}

Toda a porção do litoral norte paranaense faz parte da Área de Proteção Ambiental (APA) de Guaraqueçaba, declarada em 1985. A criação de APAs tem por finalidade "assegurar o bem-estar das populações humanas e conservar e melhorar as condições ecológicas locais" (Ipardes, 1990).

O Parque Nacional do Superagüi está inserido na APA de Guaraqueçaba como uma unidade protetora do ambiente desde 1989 e tem por finalidade "resguardar atributos excepcionais da natureza, conciliando a proteção integral da flora, da fauna e das belezas naturais, com a utilização para objetivos educacionais, recreativos e científicos, sendo neles proibida qualquer forma de exploração dos recursos naturais" (Ipardes, 1990). Este parque abrange a Ilha do Superagüi (área aproximada de 11000ha) e a Ilha das Peças (área de 10400ha), sendo que as duas possuem uma série de sítios arqueológicos como sambaquis e ruínas de construção civil.

A APA Cananéia-Iguape-Peruíbe foi criada em 1984 e ampliada em 1985. Ainda não regulamentada, encontra-se em fase de elaboração do Plano de Gestão e definição do Zoneamento Ecológico-Econômico. Localiza-se no litoral sul paulista, pertencendo ao Complexo Estuarino-Lagunar Iguape-Cananéia, rico em manguezais, sítios arqueológicos e espécies ameaçadas de extinção (Sepe, 1996).

O esporão do Ararapira, localizado na Ilha do Cardoso, faz parte do Parque Estadual do Jacupiranga (SP), que é uma das Unidades de Conservação Ambiental criada dentro da APA Cananéia-Iguape-Peruibe.

\subsection{Geomorfologia}

A planicie costeira do Paraná apresenta uma direção aproximada de seu eixo maior, NE-SW, com $90 \mathrm{~km}$ de comprimento, largura máxima (distância da linha de costa até o sopé da 
serra) de $55 \mathrm{~km}$ na região próxima a Paranaguá. As alturas, na planície costeira, não ultrapassam $20 \mathrm{~m}$ acima do nivel médio do mar.

Esta planície é recortada por complexos estuarinos como as baías de Guaratuba, a SW, de Paranaguá e das Laranjeiras, mais ao centro, e dos Pinheiros, um pouco mais a NE. Apresenta morros e colinas isolados e um grande número de ilhas, entre elas as ilhas do Mel, das Peças e do Superagüi. As zonas marginais das baías e canais da porção NE da planície costeira são constituídas de mangues e baixios semi-submersos.

A morfologia dos rios é bem distinta; na serra eles se apresentam encaixados, com padrão retilíneo e planícies aluviais estreitas, e na planície, apresentam-se meandrantes, com planicies aluviais bastante largas. Os rios, à medida que se aproximam da linha de costa, vão tendo os raios dos meandros diminuídos, até que apresentam amplas curvas, típicas de rios com influência da maré. Estes rios indicam, aproximadamente, até que porção da planície costeira, houve a influência da última transgressão marinha (Angulo, 1992).

As praias do litoral norte paranaense e extremo sul paulista são retilíneas, separadas por desembocaduras estuarinas e lagunares. São delimitadas, em direção ao continente, por um cordão de dunas frontais que, nesta porção do litoral, atingem alturas de $2 \mathrm{~m}$, recoberto por vegetação, que varia de arbustiva a rasteira. A Praia Deserta, na Ilha do Superagüi, é cortada por uma série de pequenos riachos que provêm, na sua maioria, de rios encaixados nos vales inter-cordões da planície costeira, paralelos à praia (Foto 3.3.1-Prancha $\mathrm{A}$ ).

\subsection{Geologia}

A planicie costeira paranaense e sul paulista caracteriza-se pela composição arenosa, formada durante regressões marinhas Quaternárias (Angulo, 1992). Esta planície é interrompida por uma série de sistemas estuarino-lagunares, mangues e pontões do embasamento Pré-Cambriano.

O embasamento é composto por granitos, gnaisses, xistos e diabásios. Em algumas porções chega a alcançar o mar, mas em quase toda sua extensão é encontrado apenas na porção serrana, afastada da costa.

A geologia da planície costeira paranaense vem sendo estudada por uma série de autores, sendo o trabalho mais recente de sintese, o elaborado por Angulo (1992). 
Segundo o autor, a cobertura sedimentar cenozóica, que forma praticamente toda a planície costeira, é composta por sedimentos continentais e marinhos. Os sedimentos continentais podem ser subdivididos em: a) sedimentos da Formação Alexandra, provenientes de fluxo gravitacional de detritos (ortoconglomerados) e de lama (paraconglomerados), com idade do Mioceno Inferior ou Médio; b) leques e cones aluviais que se originam nas porções onde o rio perde declividade, como na passagem da montanha para a planície, sendo caracteristicos sedimentos de grande variedade granulométrica como cascalhos com seixos e matacões em matriz areno-argilosa; c) depósitos de tálus formados pela queda de detritos; d) colúvios associados a vertentes; e e) sedimentos fluviais com idades que vão desde o PlioPleistoceno até o Holoceno.

Os sedimentos marinhos estão sub-divididos em: a) planície costeira com cordões litorâneos que se caracteriza, em sua maior parte, por sedimentos arenosos finos e muito finos que apresentam estratificações cruzadas de baixo àngulo, cruzada tabular acanalada e estratificação truncada por ondas; esta planície tem altitude em torno de $10 \mathrm{~m}$ acima do nivel médio do mar e apresenta, na porção mais interna, terraços aplainados e na mais externa, os cordões litorâneos paralelos a sub-paralelos dispostos em feixe; e b) sedimentos estuarinos.

Segundo Angulo (1992), a planicie costeira com cordões litorâneos apresenta uma série de ambientes de sedimentação atuais associados (Figura 3.4.1). São eles: a) praias; b) depressões intercordões constituidas por áreas alagadas e vegetadas e c) dunas frontais que formam cordões dunares de 20 a $80 \mathrm{~m}$ de largura com altura máxima de $6 \mathrm{~m}$, mais bem desenvolvidos no sul do Estado.

As praias do litoral sul paranaense são constituidas de areias finas e médias, bem selecionadas, com assimetria predominantemente negativa (Bigarella et al., 1966). A praia da Ilha das Peças apresenta areias finas (diâmetro médio de 0,157mm), muito bem selecionadas (desvio padrão de 0,26), com assimetria positiva e curvas de distribuição granulométrica leptocúrticas (Bigarella et al., 1978). Ainda segundo trabalho dos mesmos autores, a porção da praia localizada no extremo sul da Iha do Superagüi apresenta também areias finas, porém um pouco mais grossas do que na Ilha das Peças $(0,187 \mathrm{~mm}$ ), muito bem selecionadas (desvio padrão de 0,33 ), com assimetria negativa e curvas de distribuição granulométrica meso a leptocúrticas. 
rios e canais

planície costeira

planície costeira com cordões

litorâneos

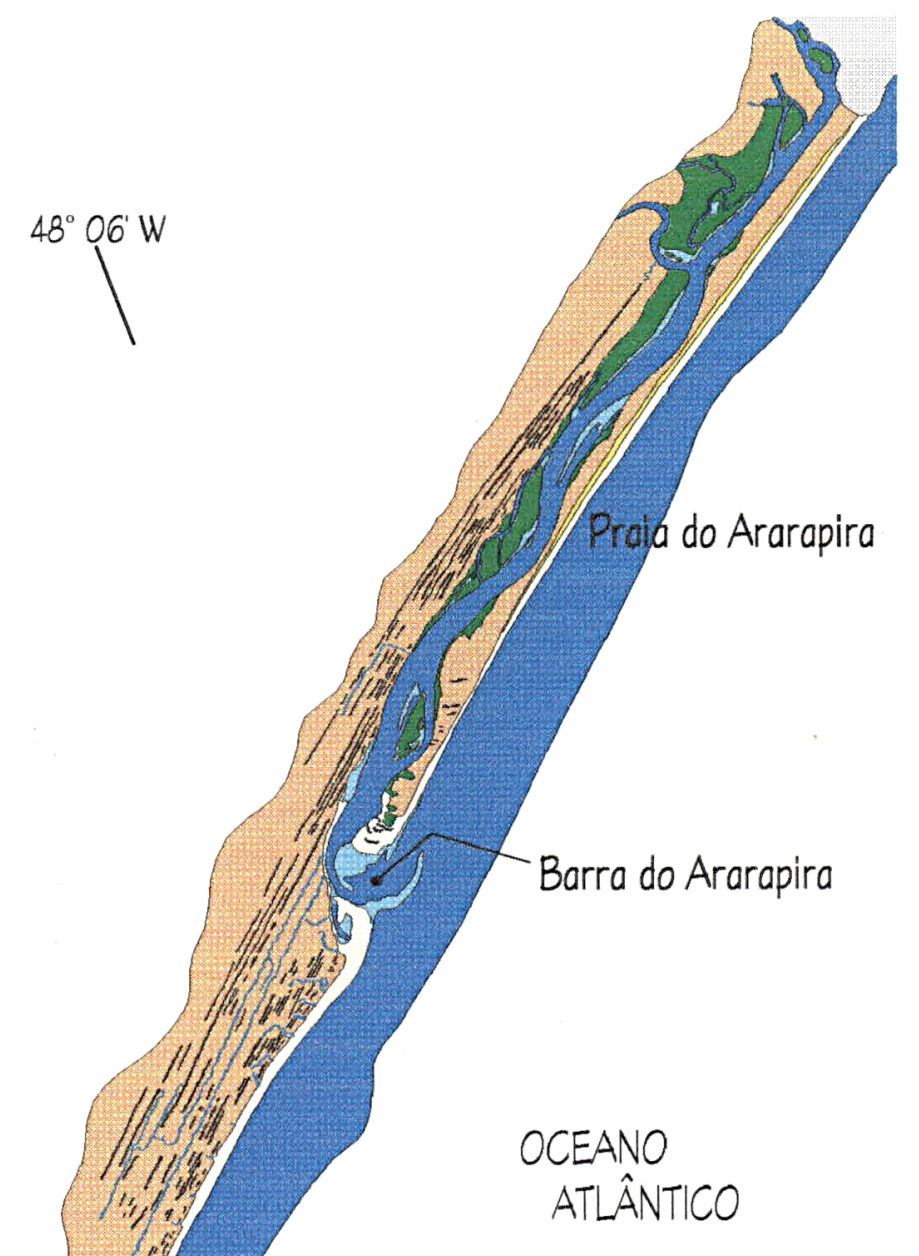

$25^{\circ} 19^{\prime}$

if Proid Deserta

$\stackrel{3 \quad 6 \mathrm{~km}}{\mathrm{O}}$

costão rochoso

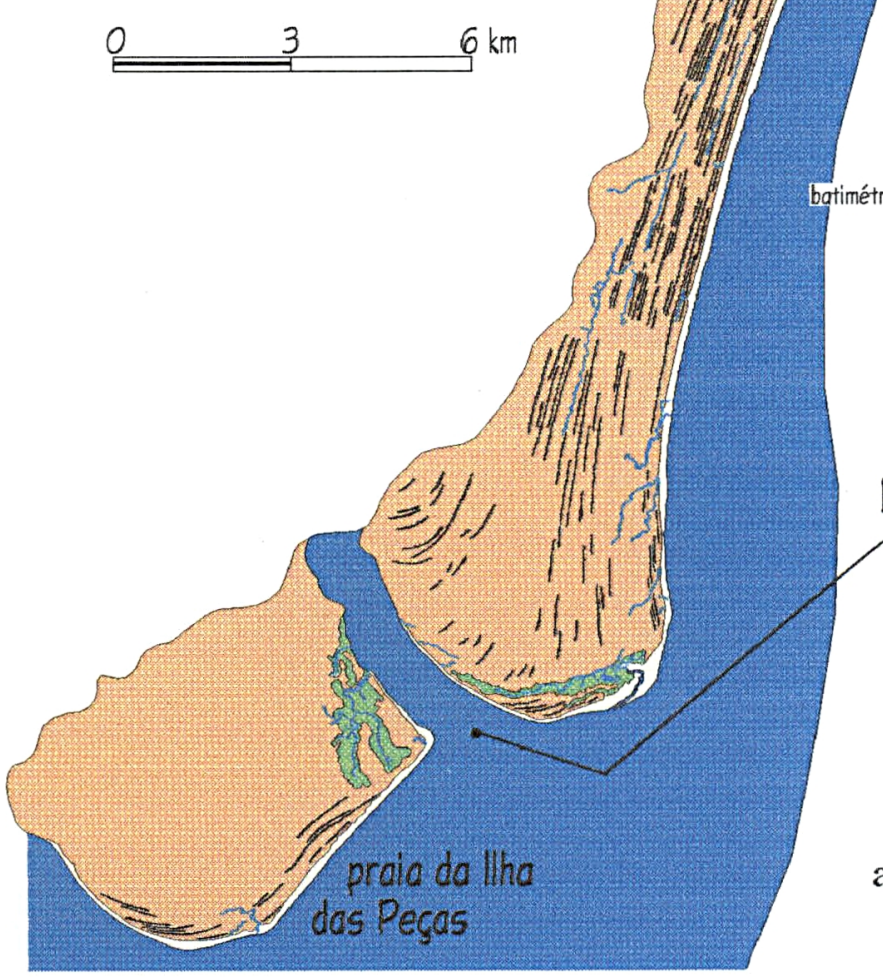

Barra do Superagüi

Figura 3.4.1. Ambientes de sedimentação atuais do litoral norte paranaense e extremo sul paulista. Mapa construído a partir do levantamento aerofotogramétrico de 1980. (modificado de Angulo, 1992) 
Segundo Angulo (1992), os sedimentos estuarinos estão compartimentados em: a) internos aos estuários, ocorrendo em canais principais; fundos médios; fundos rasos ou baixios, com profundidades de 2 metros em relação ao nível médio do mar, estes compostos por bancos areno-argilosos e marisma que se formam em áreas de sombra da corrente de maré vazante, atrás de ilhas, peninsulas e foz de rios e canais de maré que deságuam nas baias; canais de maré e planícies de maré; nestes últimos, pode-se fazer uma distinção das várias zonas em função dos ecossistemas, que são condicionados pela altitude com relação à maré, por fatores climáticos, pelo aporte de água doce e taxa de sedimentação, sendo compostos por sedimentos arenosos, argilo-arenosos e argilo-arenosos com grânulos, seixos ou conchas e apresentando teores variáveis de matéria orgânica; b) externos, localizados na entrada dos estuários, subdivididos em canais de maré e deltas de maré, estes últimos formados por depósitos arenosos associados às desembocaduras, como por exemplo, as entradas do Mar do Ararapira, do Canal do Superagüi e das baías de Paranaguá e Guaratuba; os deltas de maré podem ser identificados em fotografias aéreas, quando estão em pouca profundidade ou pelo padrão de arrebentação de ondas; e c) paleoestuarinos, compostos predominantemente por areias, com uma porcentagem mais alta de finos do que na planície costeira com cordões litorâneos, são amplamente distribuídos pela planície compondo áreas planas, baixas e com ausência de feições lineares; possuem idade holocênica, sendo pleistocênica somente no Canal do Varadouro.

A evolução geral da planície costeira paranaense, reconstituída por Angulo (1992), inicia-se após a formação de leques por fluxos de lama e detritos, provenientes de um relevo semelhante à Serra do Mar, num clima mais seco que o atual originando os sedimentos da Formação Alexandra.

Segundo o mesmo autor, as regiões onde os sedimentos continentais se apresentam muito dissecados indicam mudanças no nível de base e datam do Plio-Pleistoceno, enquanto que os pouco dissecados datam do Quaternário indiviso. Existem evidências de que durante o máximo da Transgressão Cananéia ( $\sim 20.000$ anos A.P.) o nivel relativo do mar estava situado a $8 \pm 2$ metros (Suguio \& Martin, 1978) aproximando-se do sopé da Serra do Mar. Este fato provocou, segundo Angulo (1992), o isolamento de áreas lagunares por ilhas barreira, principalmente na porção NE do Estado. Durante a fase regressiva seguinte, houve a formação de cordões litorâneos sucessivos e com o mar baixo, instalaram-se dois tipos de padrões de 
drenagem que dissecaram a planície costeira. Um instalado nos limites dos morros e da planície costeira, do qual são encontradas hoje apenas evidências, e outro, paralelo aos cordões, que hoje se apresentam na forma de vales afogados (Angulo, 1992).

Durante a Transgressão Santos, no Paraná, o mar alcançou, na fase máxima, 4 metros acima do nivel atual ( -5.100 anos A.P.) (Suguio et al., 1985 in Angulo, 1992) (Fig.3.4.2). Na fase seguinte, alcançou 2,5 metros acima do nivel atual ( $\sim 3.600$ anos A.P.), formando, segundo Angulo (1992), ilhas barreira no centro e sul do litoral. 


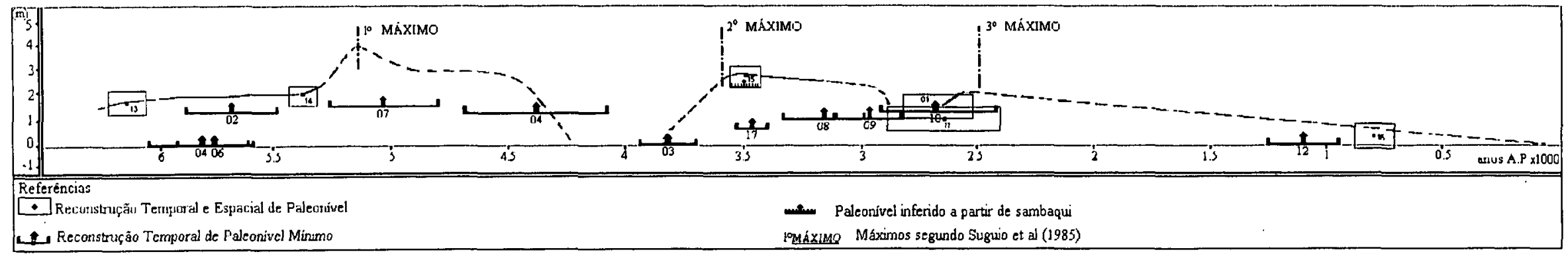

Figura 3.4.2. Curva de variação relativa do nível do mar no litoral do Paraná durante os últimos 6.500 anos A.P.

(Suguio et al., 1985 apud Angulo, 1992). 
A existência de distintas etapas transgressivas nos últimos 7.000 anos A.P. sugere oscilaçōes secundárias do nível do mar ( -4.000 e -2.900 anos A.P.) discutidas por Angulo \& Lessa (1996). Os autores sugerem uma curva contínua de abaixamento do nível do mar desde o máximo da Transgressão Santos (Fig.3.4.3). Como consequência deste abaixamento formouse uma série de cordões litorâneos (Foto 3.4.1-Prancha A) que vêm progradando até hoje. O abaixamento do nível do mar também converteu fundos rasos (baixios) em planícies de maré (Angulo, 1992). A partir dai, a configuração da linha de costa era semelhante à atual ocorrendo apenas variações associadas à dinâmica das desembocaduras.

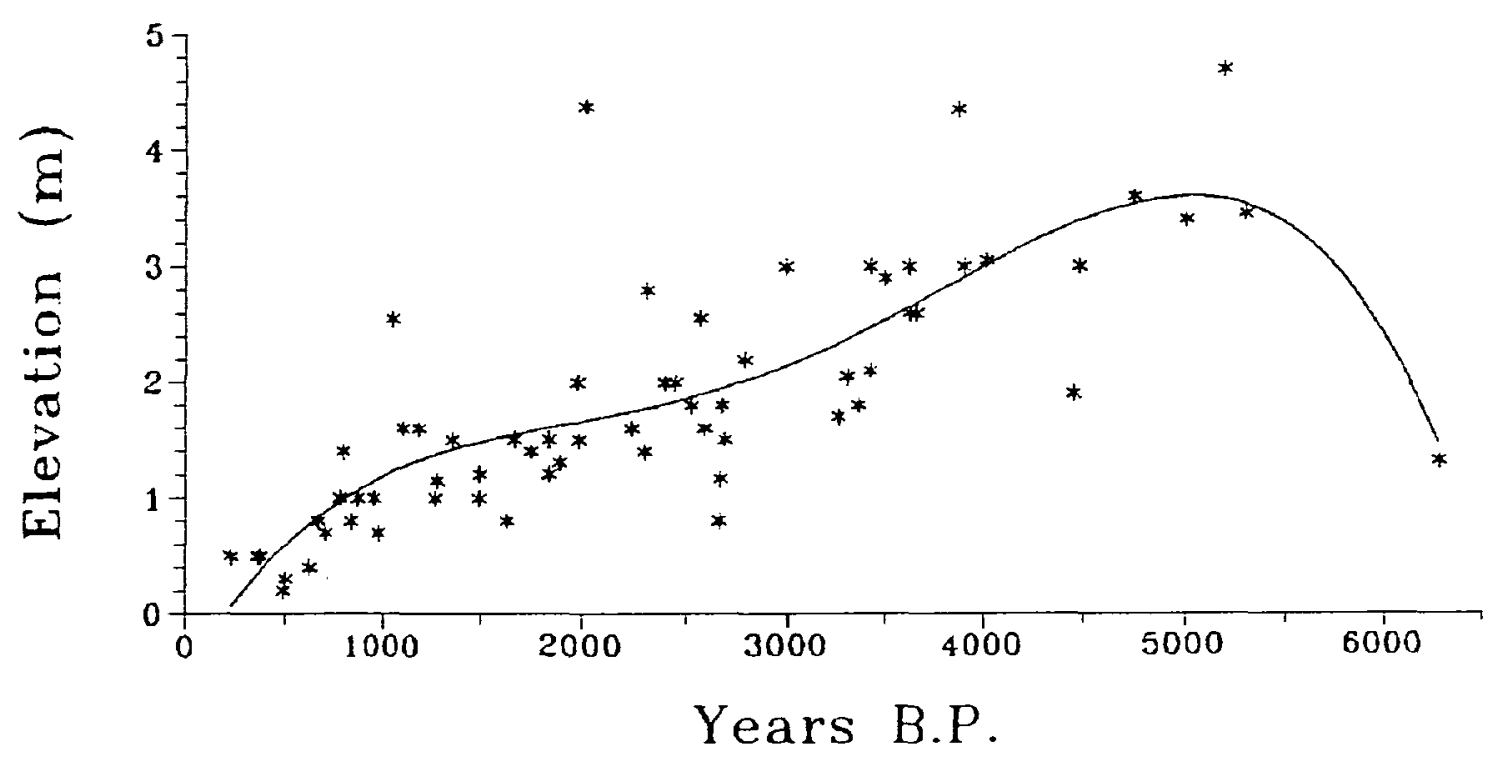

Figura 3.4.3. Elevação e idades das amostras de tubos de vermetideos coletadas ao longo da costa brasileira (Angulo \& Lessa, 1996)

Segundo Suguio \& Tessler (1992), a existência dos cordões litorâneos poderia indicar que o efeito da deriva não é dominante, mas é forte o suficiente para gerar o crescimento dos cordōes para o norte, como indicam os alinhamentos dos esporões recurvados, encontrados na Ilha Comprida, no litoral sul do Estado de São Paulo.

A desembocadura do Canal do Superagüi (Barra do Superagüi-Fig.3.1.1) sofreu um recuo da linha de costa na margem SE da Ilha das Peças de $1.300 \mathrm{~m}$ no período de 1952 a 1980. Já a desembocadura do Mar do Ararapira (Barra do Ararapira-Fig.3.1.1) sofreu um deslocamento para SW de $1.200 \mathrm{~m}$ no período de 1953 a 1980 (Angulo, 1992). 
Segundo Angulo (1995), as desembocaduras dos complexos estuarinos no litoral paranaense apresentam barras submersas e semi-submersas semelhantes a deltas de maré vazante. Os deltas de maré enchente, no entanto, não estão presentes. Ocorrem apenas, feições que apresentam evidências de terem sido originadas por correntes de maré enchente.

\subsection{Ondas e correntes de deriva litorânea}

No litoral do Paraná faltam dados sobre parâmetros de ondas. As únicas observações existentes são de medições feitas pela Portobrás, no período de agosto a dezembro de 1982, através de um ondógrafo instalado entre Praia de Leste e a Ilha de Currais. Os dados mostraram dois trens de ondas dominantes, provenientes das direções $N 74^{\circ}$ e $N 147^{\circ}$, relacionados às direções ENE e SSE/SE respectivamente (Portobrás, 1983). Neste mesmo levantamento, observou-se que as ondas mais altas vêm do quadrante SE (Tab.3.5.1).

\begin{tabular}{|c|c|c|c|c|c|}
\cline { 2 - 6 } \multicolumn{1}{c|}{} & AGO & SET & OUT & NOV & DEZ \\
\hline altura máxima (m) & 2,35 & 3,95 & 3,2 & 2,65 & 3,5 \\
\hline altura significativa (m) & 1,58 & 2,54 & 2,04 & 1,49 & 2,13 \\
\hline período médio (seg) & 16,53 & 10,73 & 12,0 & 9,8 & 12,0 \\
\hline direção & - & $112^{\circ}$ & $133^{\circ}$ & $140^{\circ}$ & $123^{\circ}$ \\
\hline
\end{tabular}

Tabela 3.5.1. Valores de altura, período e direção de ondas no período compreendido entre 21/08/82 a 21/01/83 (Portobrás, 1983). Obs. A altura significativa é definida como a altura média de $1 / 3$ das ondas mais altas e é o parâmetro utilizado nos cálculos de energia.

As direções citadas na Tabela 3.5.1. referem-se a dois sistemas distintos de geração de ondas: a direção $\mathrm{N}^{\circ} 4^{\circ}$ é gerada pela atuação dos ventos associados ao anticiclone tropical do Atlântico Sul (centro de alta pressão), caracterizando ondas bastante regulares e não tão intensas, enquanto a direção $N 147^{\circ}$ se relaciona à passagem de sistemas meteorológicos os quais podem ocasionar a formação de "ondas de tempestade" (Portobrás, 1983).

Sabe-se que a incidência obliqua das ondas na costa cria uma corrente de deriva litorânea longitudinal. Tendo em vista a direção da linha de costa e as direções das ondas dominantes citadas acima, pode-se esperar a ocorrência alternada de correntes de deriva litorânea com sentidos contrários.

Apesar da falta de medições de correntes na região costeira em estudo, alguns trabalhos feitos por Bigarella et al. (1966), Angulo (1992), Tessler \& Mahiques (1993) e 
Soares et al. (1994) assumem a corrente de deriva como sendo predominantemente de sul para norte, com base na orientação de feições morfológicas costeiras, nas últimas décadas.

Mais recentemente, foi feita uma experiència através do lançamento de garrafas de deriva, das duas desembocaduras da baía de Paranaguá. Algumas garrafas foram desviadas para o sul, porém a maior frequência de recuperação das garrafas se deu no litoral norte do Paraná e sul de São Paulo, indicando que o fluxo principal das correntes de deriva litorànea é na direção norte (Marone et al., 1995).

\subsection{Marés}

A maré no litoral paranaense e sul paulista, assim como em outras regiões do país, é do tipo semi-diurna com desigualdades diurnas, isto é, ocorrem duas preamares e duas baixamares por dia, cujas amplitudes são sensivelmente diferentes. As amplitudes normais são do tipo micro-maré (em torno de 1,5 metros).

Por vezes, no litoral paranaense as marés podem apresentar alterações na sua amplitude devido a fatores meteorológicos, como por exemplo, a passagem de frentes frias com ventos fortes provenientes do quadrante sul atuando por um tempo superior a 20 horas (Camargo, R.; IAG-USP comunicação pessoal) (Fig.3.6.1). Este tipo de fenômeno é chamado maré meteorológica, provocado $90 \%$ pela tensão de cisalhamento do vento sobre a superficie do mar. Seu efeito mais significativo ocorre em zonas litorâneas e embaiamentos, devido ao empilhamento de água na costa, sendo comumente acompanhado de episódios erosivos e destrutivos (Marone \& Camargo, 1994 e Calliari et al., 1996).

Em periodos com ausência de sistemas meteorológicos dominantes, quando existem somente as circulações locais do tipo brisa maritima, a oscilação do nível médio da maré não atinge valores anòmalos (Fig.3.6.1)

Cabe ressaltar que não necessariamente a atuação de ventos fortes na costa causa a elevação do nível médio da maré, provavelmente associado à curta duração destes ventos (Fig.3.6.1). Da mesma forma pode-se observar um aumento deste nivel sem que haja nenhum registro costeiro de ventos fortes. Este fato indica que o sistema meteorológico atuou sobre o oceano e a elevação do nível médio da maré foi detectada na costa (Marone \& Camargo, 1994). 

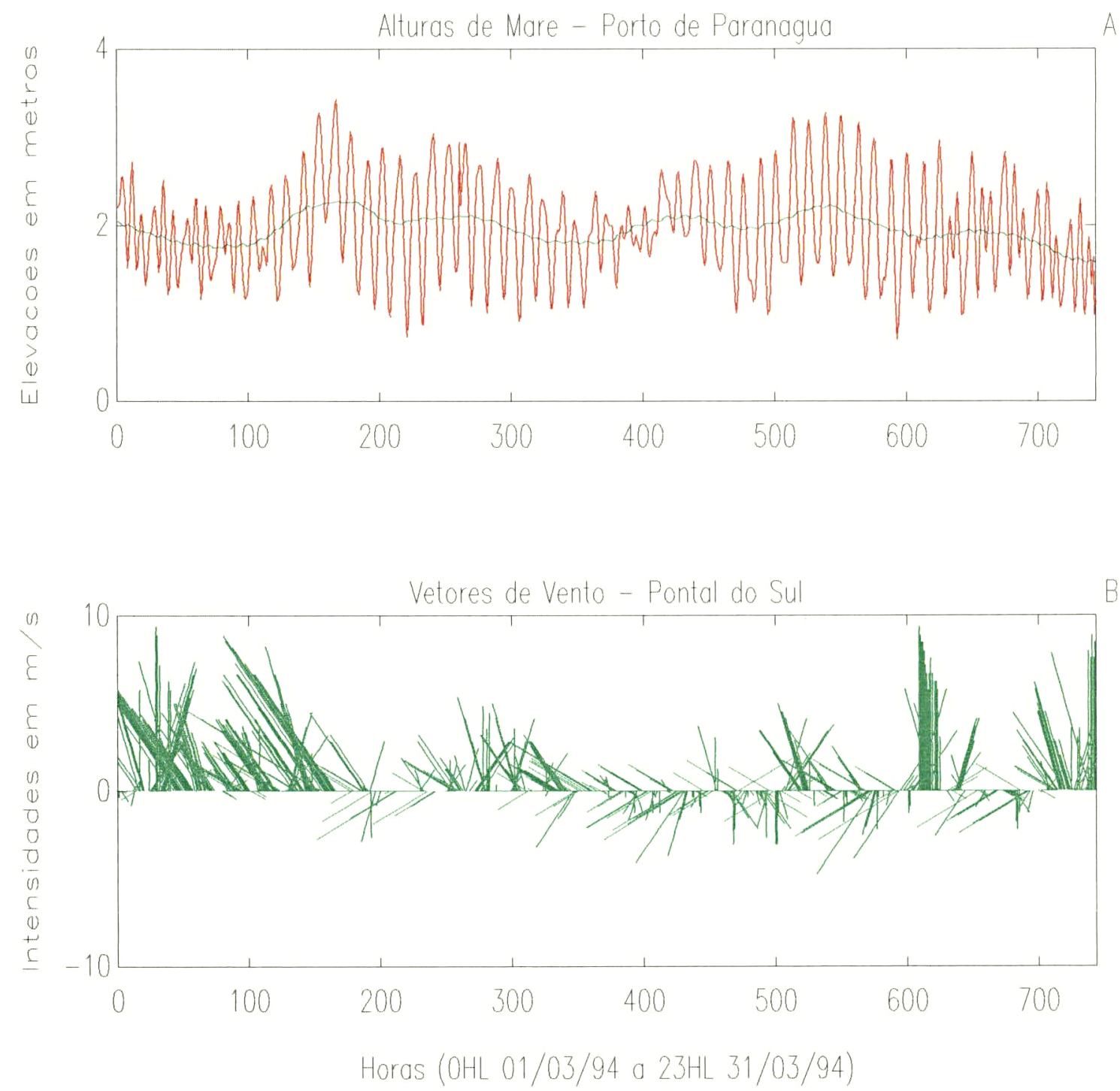

Figura 3.6.1. A. Alturas de maré no Porto de Paranaguá - PR, vermelho - valores horários e verde - valores filtrados com médias móveis de 72 horas, no mês de março de 1994 (Fonte: Administração dos Portos de Paranaguá e Antonina - APPA); B. Vetores de vento, na região de Pontal do Sul - PR, no mês de março de 1994. Obs. As barras no lado positivo do eixo das ordenadas representam os ventos provenientes do quadrante sul e do lado negativo, do quadrante norte (Fonte: Laboratório de Física Marinha - Centro de Estudos do Mar - UFPR). Exemplos: em torno da hora 170, observa-se a elevação do nível médio da maré associada à passagem de uma frente fria; em torno da hora 400, observa-se a atuação de brisa marítima sem aumento do nível médio da maré e em torno da hora 630 , observa-se a atuação de ventos fortes de curta duração, não causando a elevação do nível médio da maré.

\subsection{Fatores Meteorológicos}

A fim de analisar as condições meteorológicas durante o período de monitoramento da dinâmica das margens da Barra do Ararapira, foi feito um levantamento, junto à Climanálise (1994/1995), das passagens de frentes frias na região, e dos dados mensais de precipitação 
estimados para a área, a partir das observações de Pontal do Sul (PR), Paranaguá (PR) e Cananéia (SP).

As chuvas que ocorrem no litoral paranaense são do tipo ciclônico, orográfico e de convecção (Ipardes, 1990). Na planície litorânea a precipitação anual é em torno de $2500 \mathrm{~mm}$ (Ipardes, 1990). As estações mais chuvosas são verão e outono, quando os índices pluviométricos chegam a atingir picos de até $100 \mathrm{~mm} / \mathrm{dia}$, e as mais secas são inverno e primavera (Portobrás, 1988)

O levantamento das condições meteorológicas foi complementado com alguns valores característicos dos ventos, obtidos em Pontal do Sul (PR) através de uma estação meteorológica automática do Laboratório de Física Marinha do Centro de Estudos do Mar Universidade Federal do Paraná (LFM/CEM-UFPR) (Fig.3.6.1.B). Foram considerados os ventos provenientes do quadrante sul, com velocidades próximas ou superiores a $6 \mathrm{~m} / \mathrm{s}$ e com duração não inferior a 20 horas (Tab.3.7.1). Os ventos que registram velocidades em torno de $6 \mathrm{~m} / \mathrm{s}$ nas estações meteorológicas induzem a velocidades, próximo à superfície, de aproximadamente $4 \mathrm{~m} / \mathrm{s}$, sendo esta velocidade suficiente para uma ação efetiva no transporte de areia (Angulo, 1992).

Os ventos que apresentam as características observadas na Tabela 3.7 .1 são considerados moderados quanto à capacidade de elevar o nível médio do mar, causando o aprisionamento de água dentro do corpo lagunar. Cabe ressaltar ainda que não foram apresentados aqui eventos ocorridos em oceano aberto, que poderiam causar a elevação do nível relativo do mar, como passagem de frentes frias distantes da linha de costa, que não são detectadas pelas estações meteorológicas, mas causam empilhamento de água na região litorânea (Marone \& Camargo, 1994).

Segundo Tessler (1988), a coincidência dos períodos em que cessam os ventos decorrentes da passagem de frentes frias, ocorrendo portanto a liberação da água aprisionada dentro do corpo lagunar, e a ocorrência de maré de sizígia, causa a liberação de um volume maior de água. Este fato ocasiona o aumento no fluxo da maré vazante, aumentando assim, o poder erosivo nas margens da desembocadura. Considerando-se esta informação foi feito um levantamento dos períodos correspondentes da maré conforme a fase da lua, durante os períodos das passagens das frentes frias monitoradas (Tab.3.7.1). 


\begin{tabular}{|c|c|c|c|c|c|c|}
\hline $\begin{array}{c}\text { data } \\
\text { do } \\
\text { início }\end{array}$ & $\begin{array}{c}\text { duração } \\
\text { do vento } \\
\text { (horas) }\end{array}$ & $\begin{array}{c}\text { máxima } \\
\text { intensidade do } \\
\text { vento }(\mathrm{m} / \mathrm{s})\end{array}$ & $\begin{array}{c}\text { direção de } \\
\text { proveniência do } \\
\text { vento }\end{array}$ & $\begin{array}{c}\text { fase } \\
\text { da } \\
\text { lua }\end{array}$ & maré & $\begin{array}{l}\text { pluviosidade } \\
\text { mensal } \\
(\mathrm{mm})\end{array}$ \\
\hline \multicolumn{7}{|l|}{1993} \\
\hline $21 / 09$ & 23.5 & 7.2 & SSE-SSW & $Q$ & quadrat. & 300 \\
\hline $24 / 09$ & 25.5 & 10.3 & SW-SSW & C & quadrat. & 300 \\
\hline $05 / 10$ & 30.5 & 13.0 & $S$ & & sizígia & 100 \\
\hline $25 / 10$ & 26.5 & 8.5 & $\mathrm{~S}$ & $(3$ & quadrat. & 100 \\
\hline $16 / 12$ & 27 & 10.7 & $S$ & & sizigia & 200 \\
\hline $20 / 12$ & 24.5 & 9.8 & S-SSE & & quadrat. & 200 \\
\hline \multicolumn{7}{|l|}{1994} \\
\hline $02 / 01$ & 21 & 9.8 & SSE & & sizigia & 350 \\
\hline $21 / 01$ & 23.5 & 8.5 & SE & & quadrat. & 350 \\
\hline $01 / 03$ & 59 & 9.4 & S-SE & 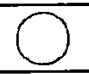 & sizigia & 350 \\
\hline $26 / 03$ & 30.5 & 9.4 & $\mathrm{~S}$ & & sizígia & 350 \\
\hline $11 / 05$ & 27 & 14.3 & SSW & & sizígia & $25-50$ \\
\hline $22 / 07$ & 21.5 & 11.2 & $S$ & & sizigia & 100 \\
\hline $16 / 08$ & 25 & 8.5 & $\mathrm{~S}$ & 7 & quadrat. & $<25$ \\
\hline $07 / 09$ & 22.5 & 8.5 & S-SSW & & sizigia & $<25$ \\
\hline $26 / 09$ & 33 & 9.4 & $S$ & D) & quadrat. & $<25$ \\
\hline $28 / 10$ & 32 & 9.8 & $\bar{S}$ & D) & quadrat. & $<25$ \\
\hline $18 / 11$ & 35 & 11.2 & SSE-SSW-SW & & sizígia & 250 \\
\hline $18 / 12$ & 22.5 & 11.6 & $\mathrm{~S}$ & ) & sizigia & 150 \\
\hline \multicolumn{7}{|l|}{1995} \\
\hline $10 / 01$ & 20 & 8.9 & S-SSW & ( & quadrat. & 200 \\
\hline $18 / 02$ & 25 & 11.6 & $\mathrm{~S}$ & 0 & sizígia & 300 \\
\hline
\end{tabular}

Tabela 3.7.1. Condições meteorológicas que caracterizam a passagem de frentes frias com ventos de duração superior a 20 horas, intensidade superior a $6 \mathrm{~m} / \mathrm{s}$, provenientes do quadrante sul, no litoral norte paranaense, no periodo de setembro de 1993 a maio de 1995 (as características do vento, maré e fases lunares foram fornecidas pelo LFM/CEM-UFPR e os dados de pluviosidade foram extraídos da Revista Climanálise - Boletim de Monitoramento e Análise Climática). 


\section{4 - MATERIAIS E MÉTODOS}

$\mathrm{Na}$ tentativa de se inferir o sentido da deriva e de se estabelecer a dinâmica dos sedimentos da área estudada foram utilizados os seguintes métodos: a análise granulométrica e mineralógica das praias do Ararapira, Deserta e da Ilha das Peças; e o estudo da migração lateral da Barra do Ararapira através de levantamentos topográficos periódicos nas margens desta e acompanhamento da erosão nas margens do corpo lagunar do Ararapira.

\subsection{Tratamento dos Sedimentos}

\subsubsection{Procedimento de Campo}

A primeira parte do trabalho foi realizada em julho de 1993, quando foram coletadas 178 amostras. Cada amostra incluiu areias desde a superficie a até $5 \mathrm{~cm}$ de profundidade, perfazendo um total de 200 gramas de material inconsolidado. Este material foi destinado à análise granulométrica e mineralógica.

A aproximadamente cada quilômetro, foram coletadas três amostras, uma na linha d'água, uma na base do cordão de dunas frontais e a outra a meia distância destas duas. $\mathrm{O}$ ponto de início da coleta foi a extremidade NE de cada uma das três praias (praia do Ararapira, Deserta e da ilha das Peças). Estas foram percorridas de bicicleta, marcando-se a distância com um hodômetro mecânico. As desembocaduras foram atravessadas de barco (Foto 4.1.1.1Prancha B).

\subsubsection{Procedimento de Laboratório}

Tendo em vista o fato de que as amostras são compostas em sua totalidade por areia quatzosa, não havendo portanto perda do material fino e não sendo necessário qualquer processo de desagregação, estas foram lavadas com água corrente para eliminação dos sais solúveis, segundo Bigarella et al. (1966), e secas em estufa a uma temperatura de $60^{\circ} \mathrm{C}$. Em seguida, foram subamostradas massas iniciais de 100 gramas para peneiramento através de vibração mecânica em rot-up durante 12 minutos. Foram utilizadas peneiras com intervalo de meio $\phi$ (phi), desde 4 a até $-0,5 \phi(0,062 \mathrm{~mm}$ a $2 \mathrm{~mm})$, sendo que as frações retidas em cada peneira foram pesadas em balança de precisão até a terceira casa decimal.

Para o estudo dos minerais pesados foram primeiramente escolhidas seis amostras, na linha de maré baixa do dia, localizadas nos extremos de cada praia. Depois, tendo em vista a necessidade de se adensar longitudinalmente os dados, foram feitas análises em mais sete 
amostras, incluindo então, porções mais ao centro de cada praia, o que totalizou treze amostras. Para a separação dos pesados foi utilizada a fração entre 3 e $3,5 \phi$, que, neste caso, corresponde à fração meio $\phi$ mais fina que a moda, conforme sugerido por Giannini (1993)

A separação foi feita, segundo método descrito por Carver (1971), em funis apropriados, submetendo-se as amostras a análise densimétrica com reagente analítico bromofórmio $\left(\mathrm{CHBr}_{3}\right)$ de densidade $2,89 \mathrm{~g} / \mathrm{cm}^{3}$, por corresponder aproximadamente ao limite entre as densidades dos minerais leves comuns (quartzo e feldspato) e os demais. Após esta etapa foi feita a lavagem do material com álcool doméstico, seguida da secagem em temperatura ambiente, dentro de uma capela de exaustão

Os minerais leves foram pesados em balança analítica de precisão até a segunda casa decimal a fim de se saber o teor de pesados contidos nesta fração e com os minerais pesados foram feitas lâminas para a identificação e contagem dos grãos ao microscópio. Antes da preparação das lâminas, foram retirados os minerais magnéticos (magnetita) atritando-se levemente a amostra, com os grãos espalhados, com imã de mão envolvido em saco plástico (Giannini, 1993)

A contagem dos grãos foi feita em microscópio petrográfico utilizando-se um contador acoplado. Foram contados 100 grãos ao longo de linhas paralelas, incluindo-se opacos e alteritos. Estes últimos são minerais que, segundo Van Andel (1958, apıd Giannini 1987), representam produtos de intemperismo de hornblenda, epidoto e piroxênio, em adiantado grau de alteração, não apresentando características de extinção e birrefringência bem definidas, o que dificulta assim, a identificação. Depois foi subtraída a quantia destes dois componentes e continuada a contagem até a totalização de, pelo menos, 100 minerais transparentes não micáceos (Galehouse, 1971) (Anexo 1).

\subsubsection{Tratamento dos resultados granulométricos}

Os valores de peso inicial e dos pesos de cada classe textural foram utilizados para cálculo de paràmetros estatísticos analíticos pela técnica dos momentos. Para isso, foi utilizado o programa MOMENTOS.WK1, criado em sistema Lotus-123 pelo Prof. Dr. Paulo César Fonseca Giannini (DEGEO-UFPR) (Anexo 2).

A distribuição dos valores de diâmetro médio, desvio padrão e assimetria foi interpretada estatisticamente através de diagramas de dispersão e de distribuição dos resíduos e análise de regressão linear (Anexo 3), a fim de se detectar tendências na distribuição espacial 
dos parâmetros granulométricos, com uma correlação definida entre os valores (Giannini \& Fernandes, 1984). Para tanto foram utilizados os softwares STATISTICA Statsoft (1993) e STATGRAPHICS Plus 7.1 (1994), respectivamente.

A análise de regressão linear foi feita entre as amostras da mesma linha de praia, para cada praia, separadamente. Nesta análise, cada valor de parâmetro granulométrico de cada amostra é comparado com o valor das amostras diretamente vizinhas.

O estudo da correlação entre os valores dos parâmetros granulométricos escolhidos foi feito utilizando-se o método de regressão linear e baseou-se nas seguintes etapas: 1) estudo dos diagramas de dispersão para identificar "células" de tendência e pontos com valores anômalos; estes foram retirados caso a anomalia persistisse nos três parâmetros granulométricos e caso os pontos correspondessem a valores anômalos também nos diagramas de distribuição dos resíduos; foram retirados também pontos muito próximos às desembocaduras, que estariam sob influência dos canais; 2) confirmação de que os resíduos (valor observado menos valor calculado ou erro de aproximação) apresentam uma distribuição normal (Bussab, 1988), neste caso a distribuição dos pontos no Diagrama de Probabilidade Normal deve aproximar-se a uma reta; este tipo de diagrama mostra o grau de dispersão dos valores dos parâmetros granulométricos em torno de uma reta que indica a tendência média destes valores; e 3) obtenção dos valores das variáveis que indicam uma correlação entre os pontos amostrados. As variáveis obtidas são:

- $\mathbf{n}=\mathrm{n}^{\underline{a}}$ de pontos ( $\mathrm{n}-1$, grau de liberdade);

- $\beta=$ inclinação da reta de equação $y=a+\beta x$;

- $\mathbf{p}=$ probabilidade de que a hipótese da inclinação da reta seja igual a zero, ou seja, de que os valores são todos iguais e que, portanto, não havendo variação, não há correlação entre as amostras $(0<p<1$, sendo que somente são considerados satisfatórios valores de $p<0,05)$, hipótese esta testada através da distribuição F de Snedecor (Landim, 1983);

- $\mathbf{R}=$ fator de correlação entre uma variável dependente (parâmetros granulométricos) e uma variável independente (distância longitudinal à praia) dos pontos $(0 \%<\mathrm{R}<100 \%)$. 


\subsection{Dinâmica da Barra do Ararapira}

A migração da desembocadura lagunar do Ararapira vem sendo observada desde 1953, data esta das primeiras fotos aéreas da região. Desde então, uma série de trabalhos foi publicada, com base em análises comparativas de levantamentos aerofotogramétricos.

O presente trabalho acompanhou a dinâmica das margens da desembocadura nos últimos três anos, aproximadamente, através de levantamentos topográficos.

\subsubsection{Procedimento de campo}

O acompanhamento da dinâmica da Barra do Ararapira foi feito através de levantamentos topográficos. Para tanto foram utilizados nível de precisão (Nikon AZ-2S), mira e trena (Foto 4.2.1.1-Prancha B).

No campo foram levantados sete perfis topográficos nas margens da desembocadura do Ararapira; quatro na margem localizada na Ilha do Superagüi, e três na margem da Ilha do Cardoso. Os perfis foram dispostos em padrão aproximadamente radial, a partir de marcos fixos locados em pontos da planície costeira (Fig. 4.2.1.1).

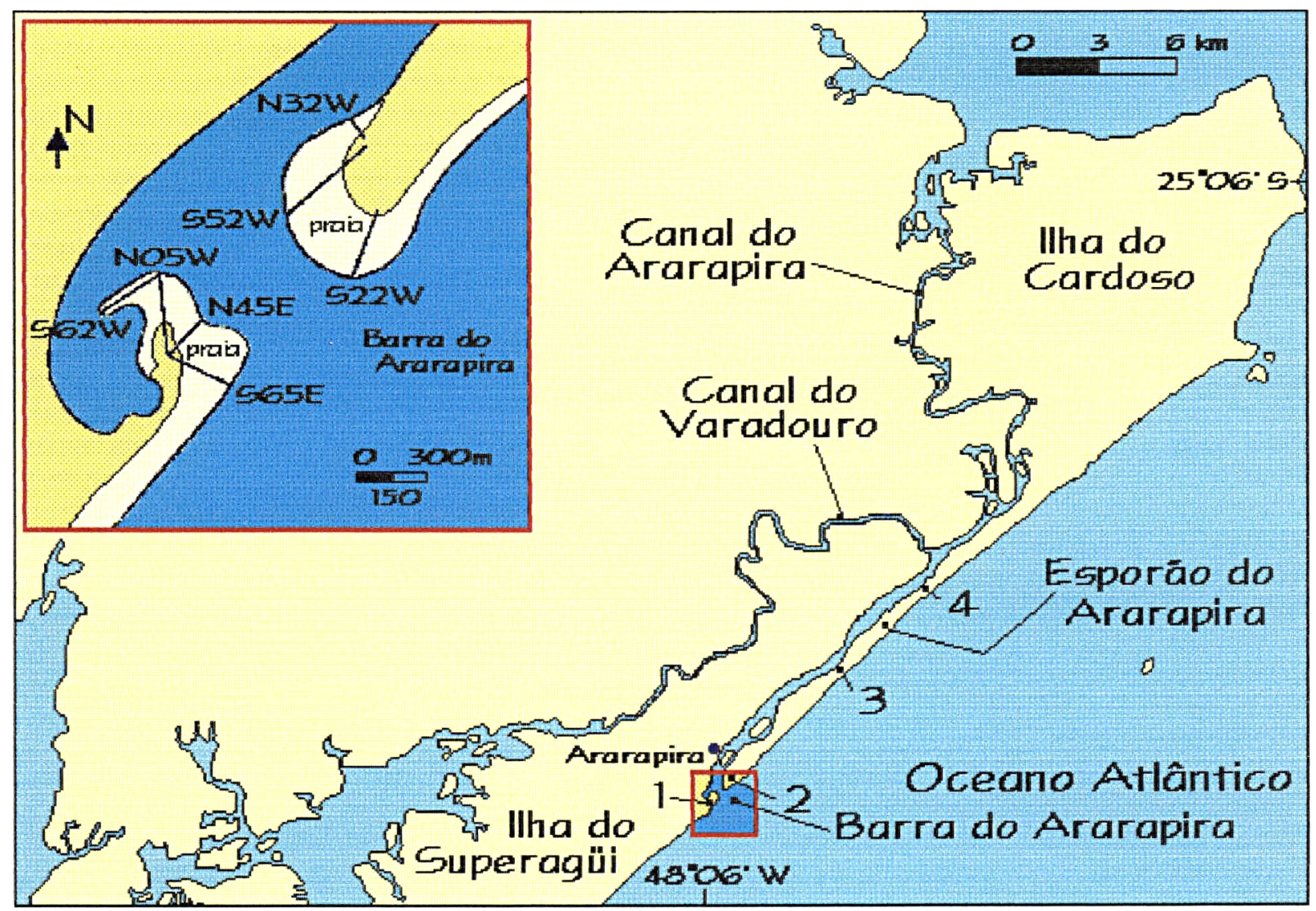

Figura 4.2.1.1. Mapa esquemático de localização dos pontos monitorados nas margens da desembocadura (pontos 1 e 2) e do corpo lagunar (pontos 3 e 4). 
Os perfis da margem da Ilha do Superagüi apresentam as seguintes direções: S62W (extremidade do esporão arenoso que delimita uma enseada), N05W (direcionado para o interior do corpo lagunar), N45E (direcionado para o interior da desembocadura) e S65E (direcionado para o oceano) (Fig.4.2.1.1). Os da margem Ilha do Cardoso estão direcionados para: N32W (para o interior do corpo lagunar) e os outros dois, S52W e $\mathrm{S} 22 \mathrm{~W}$, voltados para a desembocadura (Fig.4.2.1.1). Todos os perfis incluíram parte do campo de dunas, da planície costeira, e a praia até a linha d'água.

Os perfis foram feitos em cinco etapas, nas seguintes datas: 28/09/1993, 14/12/1993, 14/12/1994, 24/05/1995, 30/05/1996 e 31/05/1996. Infelizmente não foi possivel manter uma periodicidade nos levantamentos, devido ao dificil acesso à região.

$\mathrm{Na}$ parte mais estreita do esporão do Ararapira (Ponto 3 da Fig.4.2.1.1), foram levantados três perfis paralelos entre si (com uma distância de 30 metros entre eles) e transversais à linha de costa, abrangendo desde a falésia da margem do corpo lagunar até a linha de costa, no lado oceânico. Estes perfis também foram refeitos nas datas citadas anteriormente.

No estreito mais próximo à desembocadura do Canal do Varadouro (Ponto 4 da Fig.4.2.1.1) foi acompanhada a variação da distância entre um marco fixo e a falésia existente na margem do estuário, a partir do levantamento de 14/12/1993.

\subsubsection{Tratamento dos resultados dos levantamentos topográficos}

Os dados obtidos em campo foram plotados em software para a construção de gráficos que permitem a visualização da variação do relevo prajal e de suas feições morfológicas e para a construção de séries temporais que facilitam o acompanhamento da dinâmica de cada perfil. Para o cálculo dos volumes erodidos e depositados, primeiramente, foi criado um programa em linguagem FORTRAN para um ajuste no método de interpolação de valores, onde se considerou que cada perfil tinha um metro de largura. Após isto, foram calculados os volumes em cada trecho de praia utilizando-se o software SURFER (Golden Software, versão 5.01, 1993-94).

No cálculo dos volumes, teve-se o cuidado de comparar os valores apenas até o maior valor entre as cotas mínimas comum a todos os perfis. Por exemplo, se um perfil tinha o seu valor mínimo na cota relativa $-1 \mathrm{~m}$ e todos os outros prosseguiam até valores menores do que a batimetria de $-1 \mathrm{~m}$, a fim de se homogeneizar os valores, para poder efetuar uma comparação, os cálculos foram feitos somente até a cota relativa de $-1 \mathrm{~m}$ para cada perfil. 
Os volumes de erosão e acresção, extraídos da análise dos perfis, foram avaliados juntamente a uma série histórica da passagem de frentes frias no período, incluindo um levantamento dos índices de pluviosidade, direção e intensidade dos ventos e fases da maré e da lua (Tab.3.7.1). 


\section{5 - TRABALHOS ANTERIORES SOBRE MIGRAÇÃO LATERAL DE DESEMBOCADURAS LAGUNARES}

A migração lateral de desembocaduras e feições associadas normalmente ocorre no sentido da corrente de deriva litorânea, pela deposição na margem a montante da desembocadura, e erosão da margem a juzante.

Um modelo de migração lateral de desembocadura foi proposto por FitzGerald (1988) que supõe a "migração da desembocadura e quebra do esporão"

Este processo, segundo o autor, normalmente ocorre em canais rasos ( 3 a $4 \mathrm{~m}$ ). Nestes canais há uma constrição da desembocadura, pelo aporte de areia trazida pelas ondas e correntes de maré enchente, causando neste local um incremento na velocidade da água. Este fato aumenta o efeito de um "molhe hidráulico". O transporte litoràneo é então bloqueado, ocasionando a erosão de uma margem da desembocadura e deposição na outra, iniciando-se assim o processo de migração. Enquanto a desembocadura migra, vai deixando para trás uma série de cordões baixos e recurvados, separados por depressões pantanosas, posteriormente preenchidas por areias (Fig.5.1 tempo 1)

A migração da desembocadura resulta em uma elongação do corpo aquoso localizado atrás da barreira. Esta elongação produz, gradativamente, uma diminuição na eficiência do fluxo da maré entre o oceano e o corpo lagunar. Nestas condições, se o esporão a montante da desembocadura for quebrado (Fig.5.1 tempo 2), durante uma tempestade, por exemplo, o novo canal fornecerá um caminho mais curto de circulação de água e permanecerá aberto, enquanto que o antigo será fechado (fig. 5.I tempo 3).

Apesar do resultado final deste processo migratório ter originado uma desembocadura a montante da primeira, o processo ilustrado é típico de migração de desembocadura no sentido da corrente de deriva litorânea longitudinal. Casos de migração de desembocaduras e feições associadas no sentido contrário ao da corrente de deriva litorànea ocorrem quando o corpo aquoso dominante, localizado atrás da barreira, posicionar-se a jusante da desembocadura, em relação ao sentido da corrente de deriva litorânea. Neste caso as correntes de vazante, que fluem por este corpo, vão no sentido contrário ao da deriva. Este processo torna-se similar às condições de fluxo de um rio meandrante (FitzGerald, 1988). 

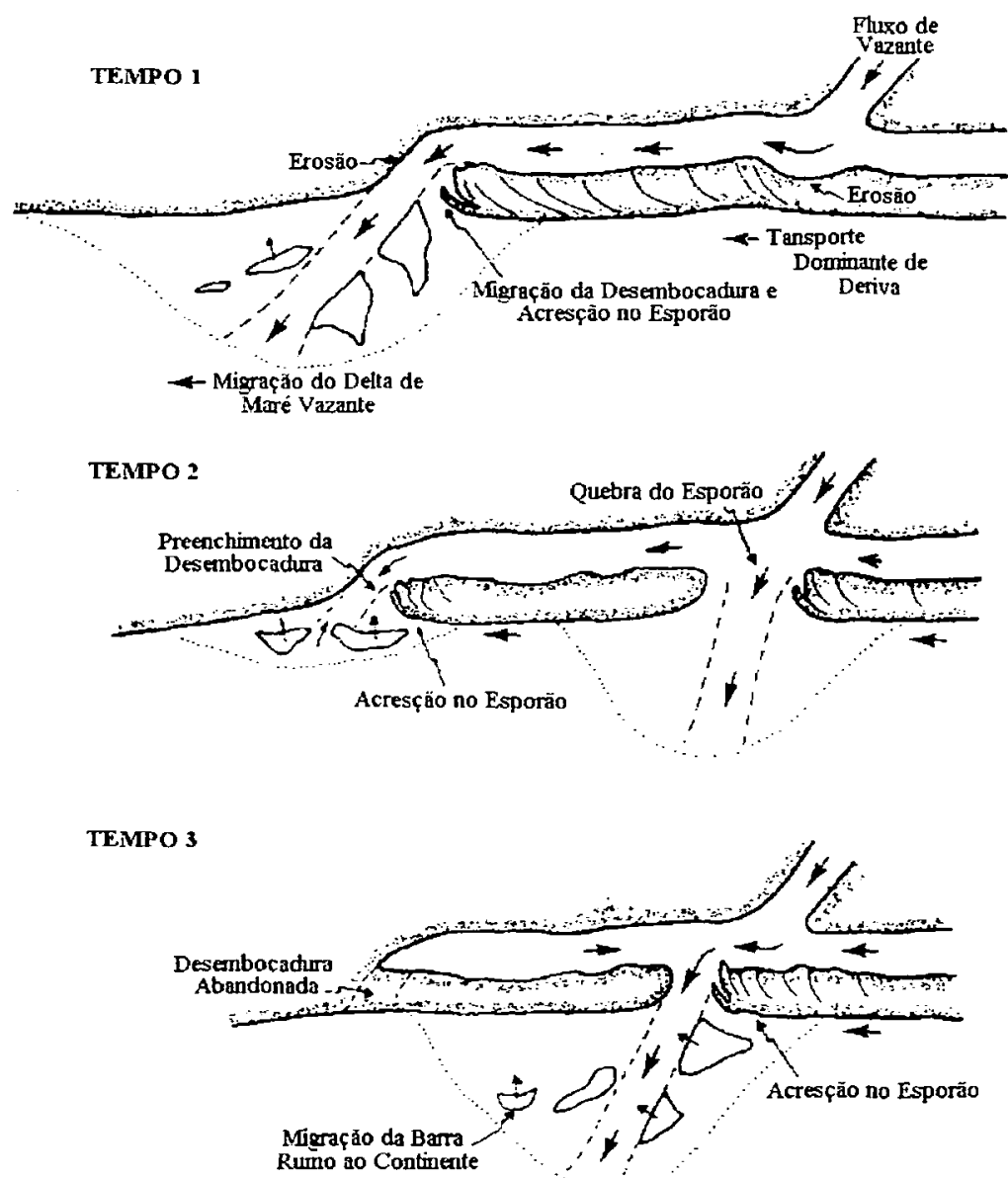

Figura 5.1. Modelo de "migração de desembocadura e rompimento do esporão" (FitzGerald, 1988).

Não são muitos os estudos sobre canais de maré que migram no sentido contrário ao da deriva. Num trabalho feito por Reddering (1983), foram observadas algumas características deste processo. São elas:

a) o fluxo de maré enchente, na desembocadura, é disperso enquanto que o de vazante se dá concentrado num canal principal, localizado próximo à margem situada a montante da desembocadura (Fig. 5.2);

b) o delta de maré vazante sofre uma grande inflexão devido à ação das correntes de deriva litorânea, sendo então denominado delta de deriva litorânea; este fato controla parcialmente o curso do canal de vazante, que influencia na direção de migração (Fig.5.2);

c) durante a maré enchente o depósito de delta de maré enchente funciona como tal, porém na maré vazante ele tem uma característica de barra em pontal como num sistema meandrante; 
d) o fluxo de maré vazante sofre uma aceleração na desembocadura devido ao estrangulamento desta e à inércia com que chega a este ponto, assumindo a posição preferencial do canal principal, adjacente à margem erosiva (margem localizada a montante da desembocadura) (Fig.5.2);

e) ao mesmo tempo ocorre uma célula de fluxo, caracteristica de fluxo helicoidal em meandros (Davis, 1983), que vai da borda para o meio do canal, jogando areia nos canais de maré enchente; este fato cria um padrão tridimensional que erode uma margem e deposita na outra (Aubrey \& Speer, 1983);

f) a migração é esporadicamente acelerada por reversões temporárias no sentido da corrente de deriva litorânea e durante enchentes fluviais (Reddering, 1983)

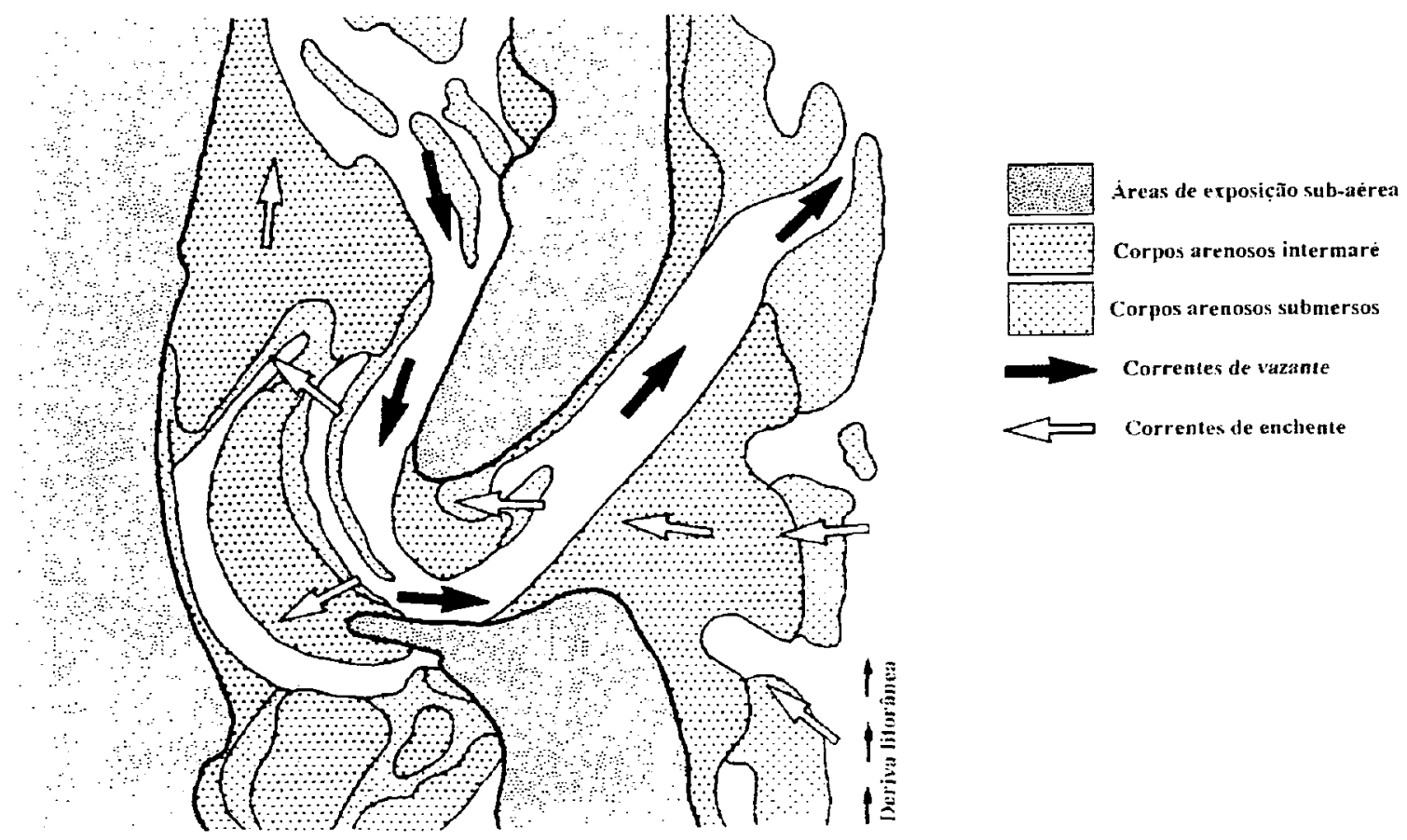

Figura 5.2. Padrão de circulação das correntes de maré e distribuição das areias (Reddering, 1983).

No Brasil, um exemplo de migração de desembocaduras no sentido contrário ao da deriva é a migração da Barra do Ararapira.

O primeiro trabalho feito sobre a região da Barra do Ararapira foi de Tessler (1988), através da superposição das fotos aéreas de $1953^{1}, 1963$ e 1981 que constatou a migração da

\footnotetext{
${ }^{3}$ As fotos consideradas como sendo de 1953 na realidade incluem um vôo feito em 1952 e outro feito em 1955 para completar algumas áreas não varridas pelo primeiro.
} 
barra para SW, sentido este, oposto ao da deriva litorânea (Fig.5.3). Segundo o autor, esta migração dá-se pela erosão da margem côncava, associada em continuidade lateral a uma feição do tipo pontão arenoso, que se desenvolve no rumo ENE, e progradação da margem oposta pelo crescimento de "ilhas arenosas". O processo de erosão da margem côncava apresenta-se semelhante ao padrão de um rio meandrante, em que os fluxos mudam de sentido de acordo com a maré. Já o mecanismo de bloqueio do transporte litorâneo pela corrente de maré vazante (molhe hidráulico) juntamente com a ação das ondas seriam responsáveis pelo crescimento do pontão arenoso e dos bancos de areia existentes na porção frontal à desembocadura.
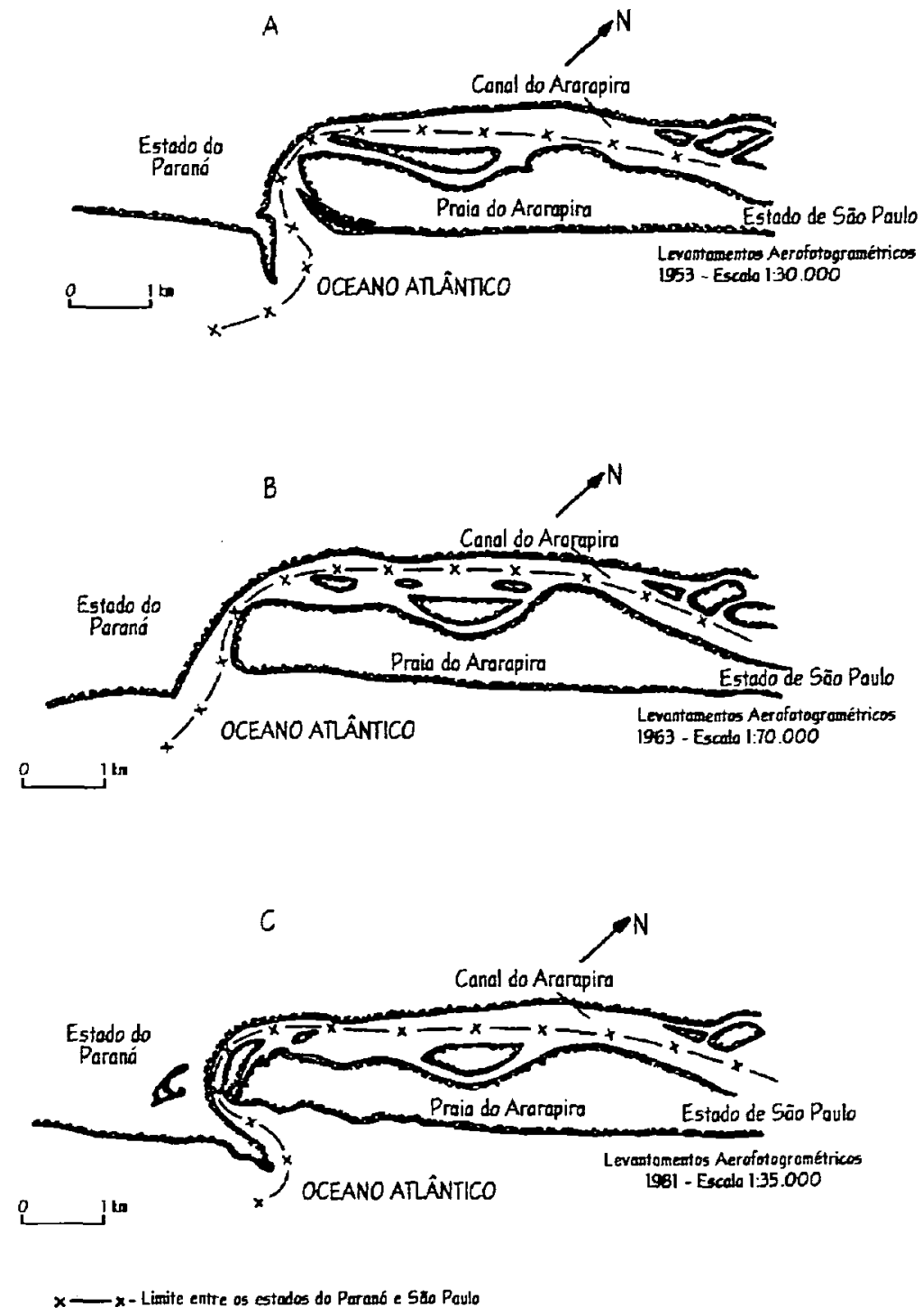

Figura 5.3. Evolução da desembocadura lagunar do Ararapira: (A) 1953, (B) 1963, (C) 1981. (Tessler \& Mahiques, 1993). 
O processo de erosão da margem còncava acentua-se após a passagem de frentes frias, pelo aumento do volume de água no interior dos sistemas lagunares, aprisionada por ventos de direções S-SE. Este evento atmosférico, somado às marés mais intensas, aumenta o fluxo da maré vazante que, juntamente com um maior transporte litorâneo, acelera os processos erosivos e deposicionais. Segundo Tessler \& Mahiques (1993), o pontão arenoso e os bancos submersos localizados em frente à desembocadura tenderiam a obstruí-la, porém durante os eventos de fortes marés vazantes estas areias seriam deslocadas rumo ao oceano e posteriormente seriam remobilizadas pela deriva litorânea e incorporadas à margem convexa da Barra do Ararapira.

Angulo (1992) também descreveu feições sedimentares encontradas nas imediações da Barra do Ararapira, que interpreta como um pequeno delta de maré vazante, em forma de arco, localizado na porção frontal do canal principal, em continuação ao pontão arenoso da margem còncava. Este delta estaria representado por barras submersas e semi-submersas.

A existència de uma plataforma semi-submersa no extremo do esporão do Ararapira, em forma de rampa, com dunas subaquosas que migram para o interior do Mar do Ararapira, poderia representar um delta de maré enchente ou feição associada (Angulo, 1992) (Fig.5.4), sugerindo que a circulação preferencial das correntes de maré enchente é pelo canal localizado a leste, entre a costa e o delta de maré vazante (Angulo, 1995).

A localização de barras desenvolvidas próximas à margem còncava e a circulação preferencial das correntes de maré enchente, próximas à margem convexa da desembocadura, indicam um transporte litorâneo predominante no sentido nordeste, aproximando a morfologia do delta ao tipo "dominado por ondas com transporte predominantemente numa direção" de Oertel (1975) (Angulo, 1995) (Fig.5.4 e Fig. 1.2-C). 


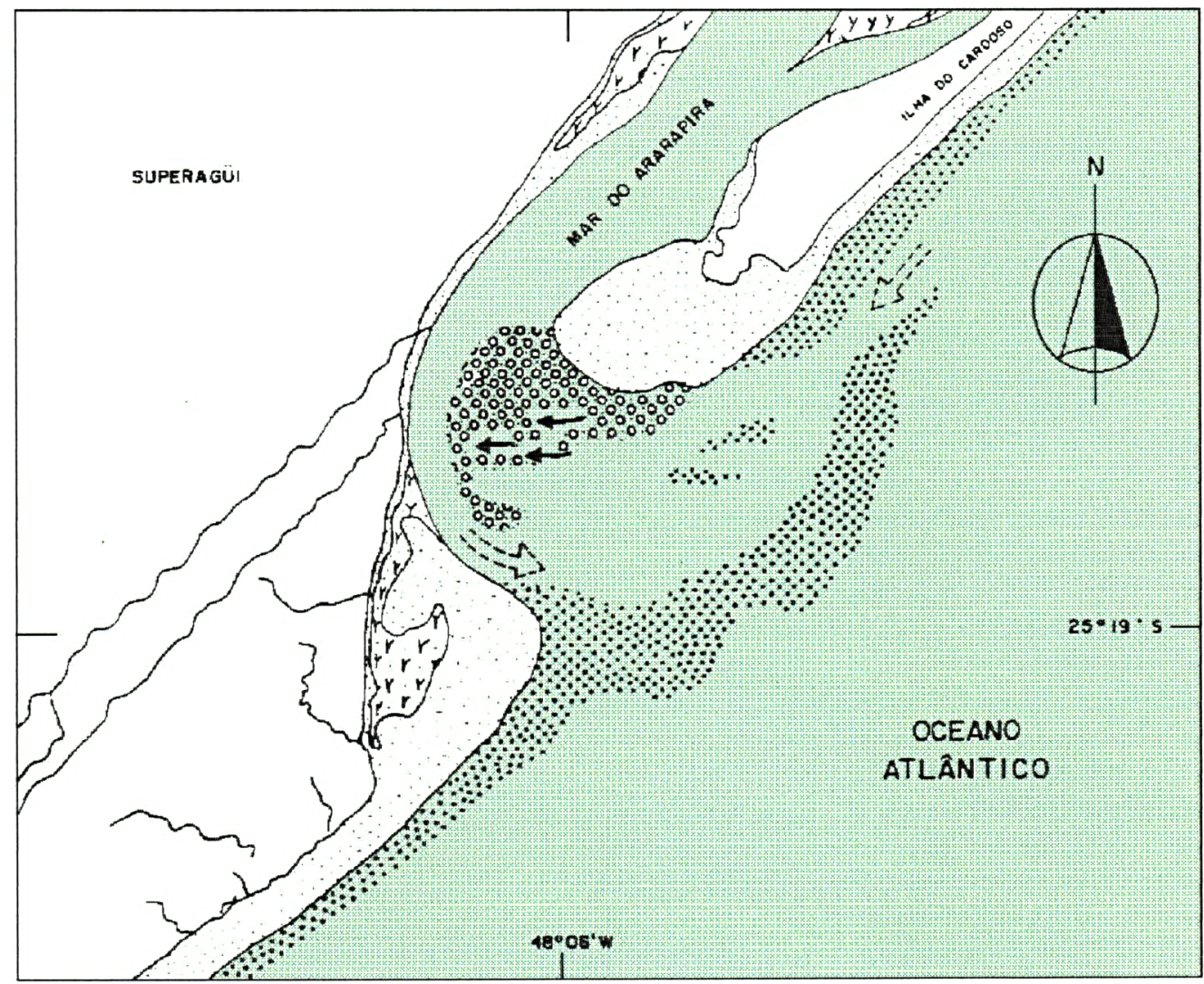

Referências

Escala

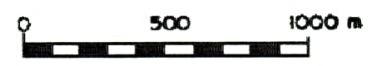

$\because \because \because$ Delta de more vazonte

$0 \%$ Formos associodas a correntes de mare enchente

Planicie costeiro

- Sentido de migracōo dos mega onduiaçōes

r.r. Bancos e fundos resos

Direcōo de corrente de maré inferida

L Fios e córregos

Figura 5.4. Delta de maré vazante e formas associadas às correntes de maré enchente na entrada do Mar de Ararapira, limite entre os

Estados do Paraná e São Paulo (Angulo, 1992).

Angulo (1992) faz uma constatação do sentido unidirecional de migração da barra, no período entre 1953 e 1980, de $1.200 \mathrm{~m}$ para SW (Fig.5.5). 


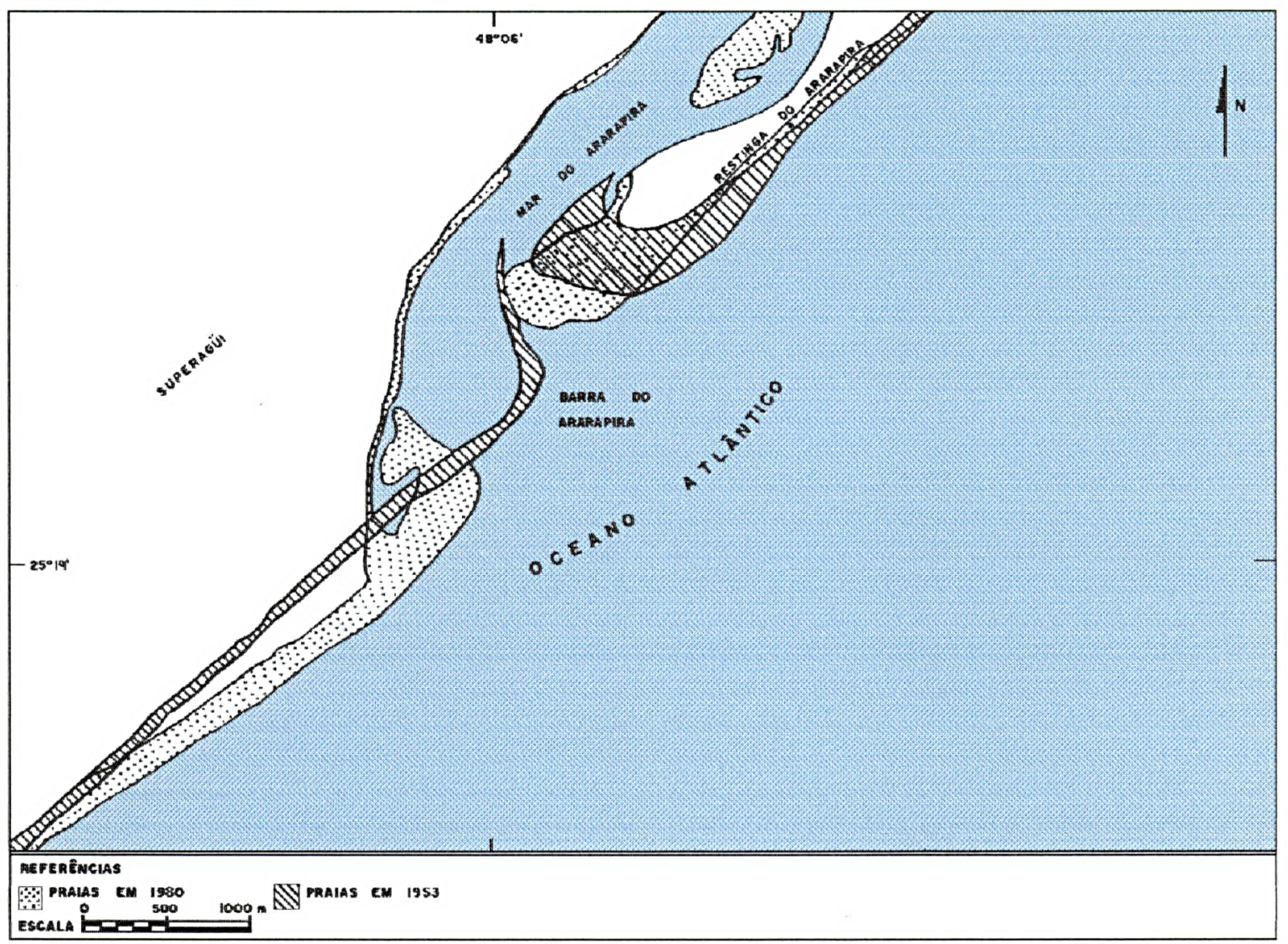

Figura 5.5. Variação na configuração da linha de costa na Barra do Ararapira, no período de 1953-1980 (Angulo, 1992).

Angulo (1993), num estudo sobre a ocupação urbana da linha de costa, observa a erosão de mais de 100 ha de planície costeira devido à migração da barra nos últimos 40 anos, forçando os moradores locais a deslocar suas residências e abandonar suas roças. Os problemas não têm sido maiores devido à baixa taxa de ocupação da área. 


\section{6 - RESULTADOS}

\subsection{Distribuição dos parâmetros granulométricos}

Com a finalidade de se tentar identificar qual a possível influência da corrente de deriva litorânea longitudinal e a ação das ondas e ventos sobre a distribuição dos sedimentos praiais, foi feita uma comparação das características granulométricas das areias, tanto na direção normal à praia, quanto longitudinal a esta. Para este fim foram amostrados os sedimentos de três linhas da praia. São elas: a base do cordão dunar voltada para a praia, a linha de preamar e a linha de baixa-mar.

As características granulométricas das praias estudadas são muito semelhantes, sendo que seus sedimentos são compostos por areias finas (média de diâmetro médio de 2,83 $\phi$ ), de acordo com a escala de Wentworth (1922), às vezes tendendo para termos mais finos, em algumas porções restritas das praias como na base do cordão dunar, e mais grossos, na linha de baixa-mar (Fig.6.1.1).

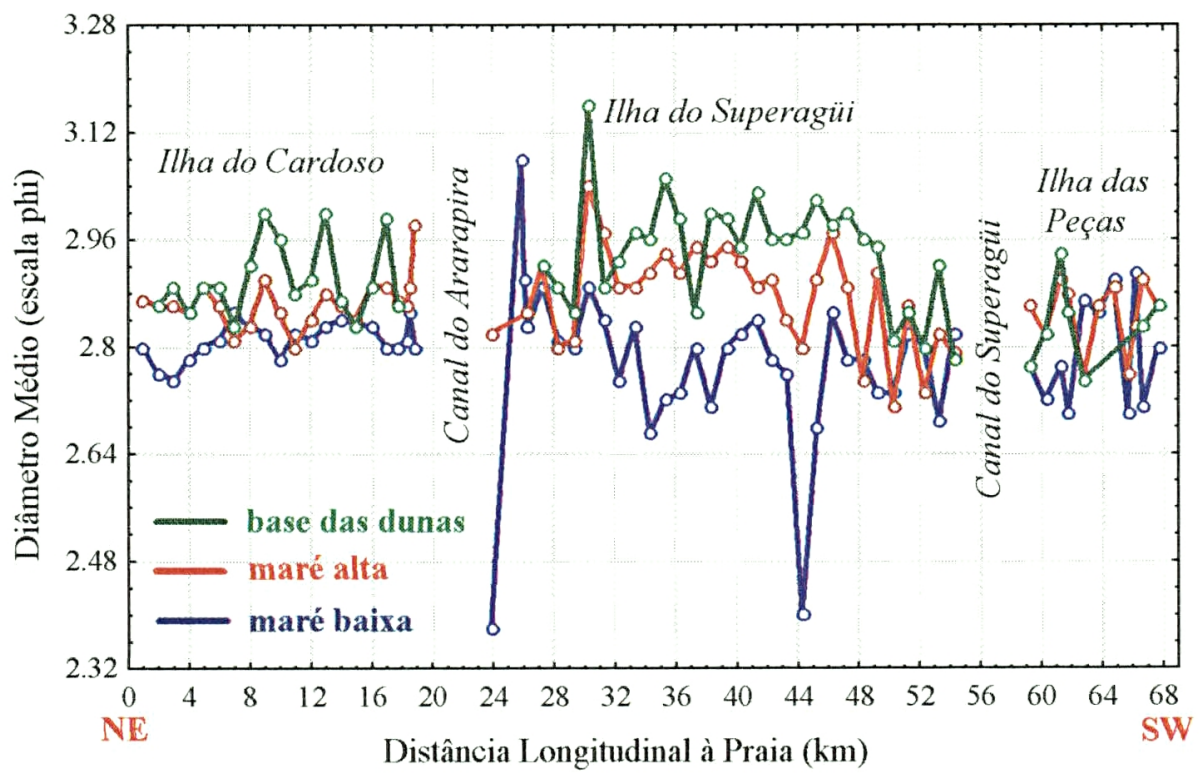

Figura 6.1.1. Distribuição dos valores de diâmetro médio $(\phi)$, nas três linhas amostradas, ao longo das praias nas ilhas do Cardoso, do Superagüi e das Peças.

Os valores de desvio padrão permitem caracterizar as areias das praias como muito bem selecionadas $(0,28$, em relação à média expressa em $\phi)$ na classificação nominal de Folk \& Ward (1957). Somente na linha de baixa-mar, da praia da Ilha do Superagüi, observa-se uma seleção um pouco mais pobre em relação às outras linhas e às outras praias (Fig.6.1.2). 


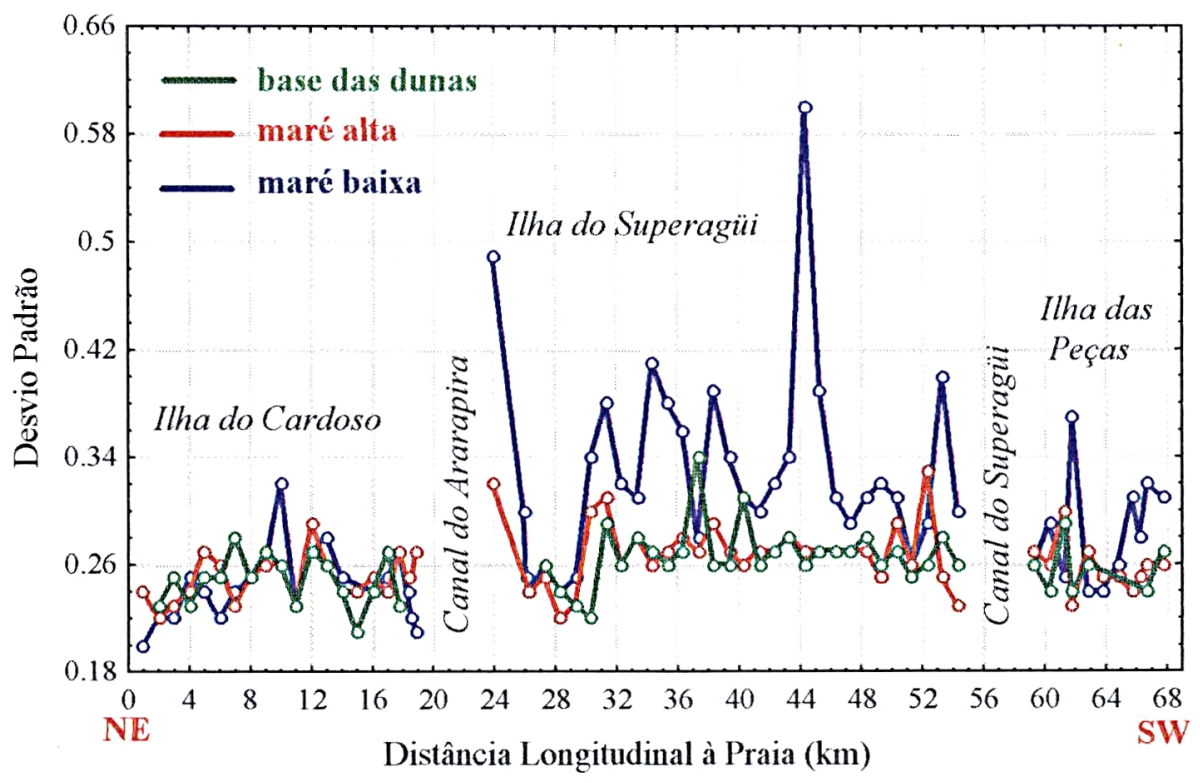

Figura 6.1.2. Distribuição dos valores de desvio padrão, nas três linhas amostradas, ao longo das praias nas ilhas do Cardoso, do Superagüi e das Peças.

Os valores de assimetria são os que mais diferem entre as três praias. O valor médio observado é aproximadamente $+0,07$, o que aproxima a distribuição da granulometria a uma distribuição normal de freqüências . Em linhas gerais, porém, a linha de baixa-mar apresenta os valores de assimetria mais negativos enquanto que as outras linhas tendem para assimetrias mais positivas (Fig.6.1.3)

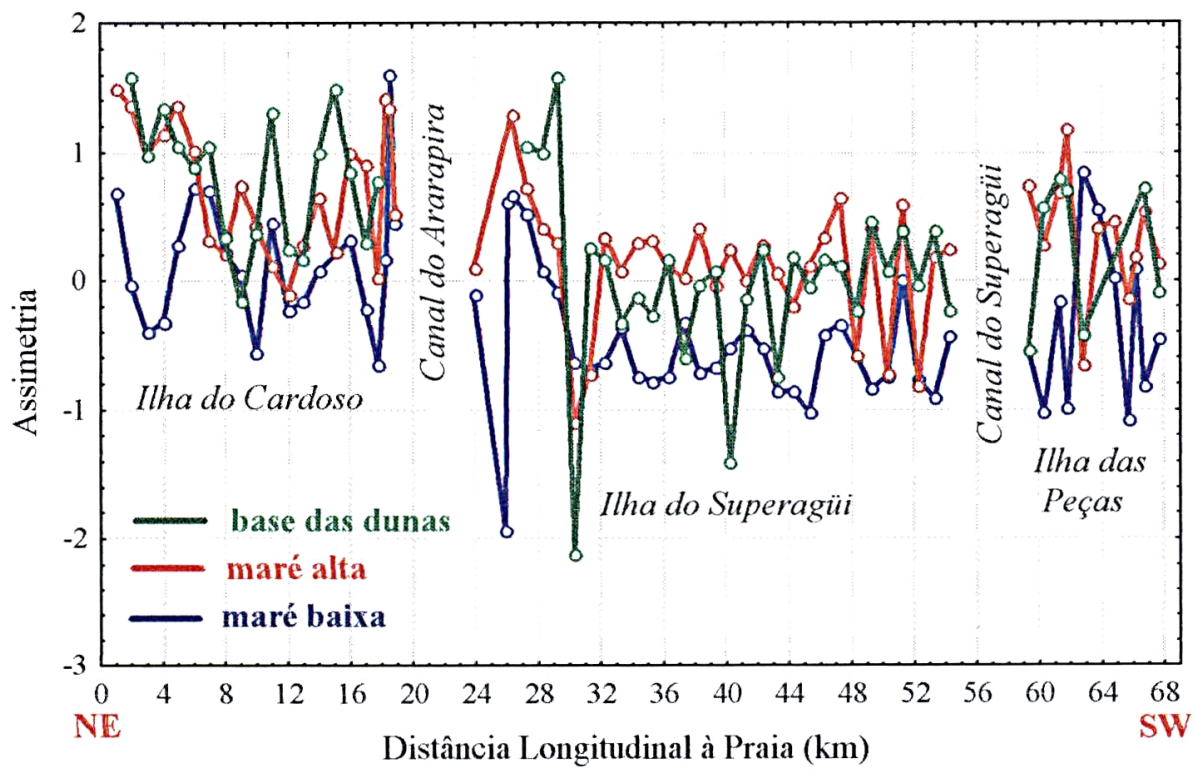

Figura 6.1.3. Distribuição dos valores de assimetria, nas três linhas amostradas, ao longo das praias nas ilhas do Cardoso, do Superagüi e das Peças. 
A medida de curtose média para as praias apresenta valor em torno de 5,14. caracterizando a curva de distribuição de freqüências da granulometria como leptocúrtica (Friedman \& Sanders, 1978). Estes valores sofrem um aumento na linha de baixa-mar e um decréscimo na base do cordão dunar (Fig.6.1.4).

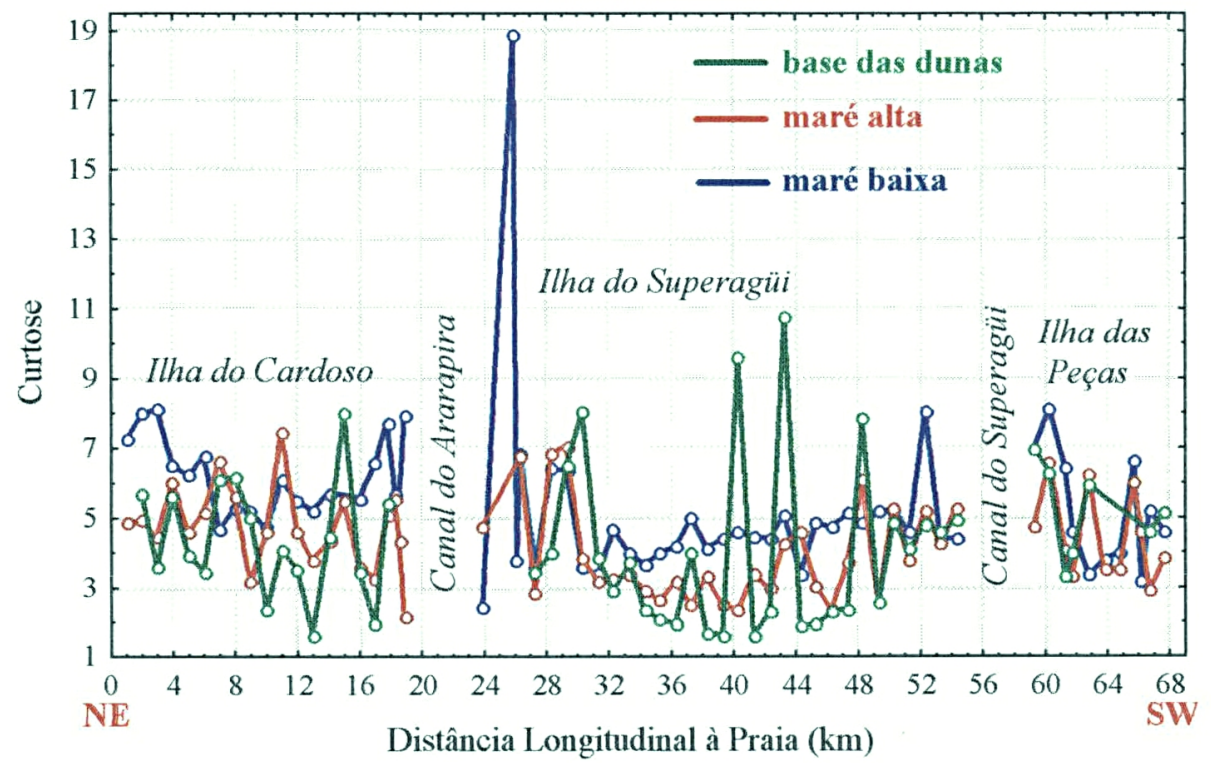

Figura 6.1.4. Distribuição dos valores de curtose, nas três linhas amostradas, ao longo das praias nas ilhas do Cardoso, do Superagüi e das Peças.

Na praia da Ilha do Cardoso as areias apresentam, em média, assimetria positiva nas três linhas estudadas, porém menos positiva na linha de baixa-mar. Estes valores indicam deșvios da normalidade no sentido de classes texturais mais grossas (Coimbra et al., 1991) na linha de baixa-mar (Tab.6.1.1).

\begin{tabular}{|c|c|c|c|c|c|}
\hline $\begin{array}{c}\text { Linha de } \\
\text { amostragem }\end{array}$ & $\begin{array}{c}\text { Diâmetro } \\
\text { Médio }(\phi)\end{array}$ & $\begin{array}{c}\text { Desvio } \\
\text { Padrão }\end{array}$ & Assimetria & Curtose & $\begin{array}{c}\text { Moda - Areia } \\
\text { Fina (\%) }\end{array}$ \\
\hline baixa-mar & 2,81 & 0,24 & $+0,14$ & 6,16 & 82,09 \\
\hline preamar & 2,86 & 0,25 & $+0,89$ & 4,85 & 76,10 \\
\hline $\begin{array}{c}\text { base do } \\
\text { cordão dunar }\end{array}$ & 2,90 & 0,25 & $+0,80$ & 4,31 & 69,49 \\
\hline
\end{tabular}

Tabela 6.1.1. Médias dos valores de cada parâmetro granulométrico dos sedimentos, nas três linhas amostradas, da praia da Ilha do Cardoso (SP).

$\mathrm{Na}$ praia da Ilha do Superagüi a assimetria difere bastante nas três linhas de amostragem. Na base do cordão dunar as areias apresentam-se aproximadamente simétricas. 
$\mathrm{Na}$ linha de preamar a assimetria é positiva e na linha de baixa-mar, é negativa, indicando o excesso de areias mais finas e mais grossas, respectivamente (Tab.6.1.2).

\begin{tabular}{|c|c|c|c|c|c|}
\hline $\begin{array}{c}\text { Linha de } \\
\text { amostragem }\end{array}$ & $\begin{array}{c}\text { Diâmetro } \\
\text { Médio }(\phi)\end{array}$ & $\begin{array}{c}\text { Desvio } \\
\text { Padrão }\end{array}$ & Assimetria & Curtose & $\begin{array}{c}\text { Moda - Areia } \\
\text { Fina (\%) }\end{array}$ \\
\hline baixa-mar & 2,79 & 0,34 & $-0,45$ & 4,83 & 77,72 \\
\hline preamar & 2,88 & 0,27 & $+0,11$ & 5,32 & 69,53 \\
\hline $\begin{array}{c}\text { base do } \\
\text { cordão dunar }\end{array}$ & 2,94 & 0,27 & $-0,05$ & 4,01 & 59,58 \\
\hline
\end{tabular}

Tabela 6.1.2. Médias dos valores de cada parâmetro granulométrico dos sedimentos, nas três linhas amostradas, da praia da Ilha do Superagüi (PR).

Na praia da Ilha das Peças a assimetria apresenta-se positiva na linha de preamar e base do cordão dunar e negativa na linha de baixa-mar, o que representa um desvio da normalidade no sentido de granulações mais grossas em direção à baixa-mar (Tab.6.1.3).

\begin{tabular}{|c|c|c|c|c|c|}
\hline $\begin{array}{c}\text { Linha de } \\
\text { amostragem }\end{array}$ & $\begin{array}{c}\text { Diâmetro } \\
\text { Médio }(\phi)\end{array}$ & $\begin{array}{c}\text { Desvio } \\
\text { Padrão }\end{array}$ & Assimetria & Curtose & $\begin{array}{c}\text { Moda - Areia } \\
\text { Fina (\%) }\end{array}$ \\
\hline baixa-mar & 2,79 & 0,29 & $-0,32$ & 5,16 & 78,68 \\
\hline preamar & 2,85 & 0,26 & $+0,34$ & 4,49 & 76,41 \\
\hline $\begin{array}{c}\text { base do } \\
\text { cordão dunar }\end{array}$ & 2,83 & 0,26 & $+0,25$ & 5,18 & 78,01 \\
\hline
\end{tabular}

Tabela 6.1.3. Médias dos valores de cada parâmetro granulométrico dos sedimentos, nas três linhas amostradas, da praia da Ilha das Peças (PR).

$\mathrm{Na}$ tentativa de correlacionar os valores dos parâmetros granulométricos, ao longo das praias estudadas, bem como avaliar a tendência na distribuição destes parâmetros, foi realizado o estudo de regressão linear.

O estudo de regressão linear na distribuição dos parâmetros granulométricos não se mostrou muito satisfatório, devido aos baixos valores de correlação entre os parâmetros granulométricos de amostras vizinhas, da mesma linha de praia. Os melhores valores de correlação obtidos, chegaram a pouco menos de $40 \%$.

Analisando-se primeiramente as praias em conjunto, observa-se, para as amostras da linha de baixa-mar, de SW para NE, um pequeno aumento no valor do diâmetro médio ( $\phi)$, portanto diminuição no tamanho dos grãos, um aumento na seleção e uma tendência para assimetrias mais positivas. Os valores de diâmetro médio, no entanto, apresentaram correlação 
inferior a $5 \%$, enquanto que os outros parâmetros apresentaram correlação em torno de $20 \%$. $\mathrm{Na}$ linha de preamar e no cordão de dunas frontais alguns valores de correlação atingiram $15 \%$, mas a maioria se manteve abaixo de $10 \%$.

Os sedimentos na linha de baixa-mar da praia da Ilha do Cardoso apresentaram-se, no sentido NE, mais grossos, melhor selecionados e com assimetria mais positiva, com valores de correlação inferiores a $5 \%$ para a assimetria e um pouco superiores a $30 \%$ para os outros parâmetros (Anexo 3, Tab. 3.1).

A análise de regressão linear para os parâmetros granulométricos, na linha de preamar, apresentou valores de correlação inferiores a $2 \%$ para o diàmetro médio; em torno de $10 \%$ para o desvio padrão; e aproximadamente $40 \%$ para a assimetria. Nesta linha de praia houve, no sentido NE, um pequeno aumento no tamanho dos grãos, melhoria na seleção e assimetria mais positiva (Anexo 3, Tab. 3.2). $\mathrm{Na}$ base do cordão dunar os valores de correlação mantiveram-se abaixo de 10\% (Anexo 3, Tab. 3.3).

$\mathrm{Na}$ praia da Ilha do Superagüi as três linhas apresentaram, no sentido NE, uma diminuição no tamanho dos grãos, um aumento na seleção e assimetria mais positiva. Porém os valores de correlação não foram satisfatórios para nenhuma das linhas amostradas, mantendo a maioria dos valores de correlação abaixo de 15\% (Anexo 3, Tab.3.4 a 3.6).

Os sedimentos da Ilha das Peças foram os que apresentaram os piores valores de correlação, que se mantiveram, na maioria, abaixo de 6\% (Anexo 3, Tab.3.7 a 3.9). Portanto não foi considerada a distribuição dos parâmetros granulométricos desta praia, para efeito de identificação de tendência.

McLaren \& Bowles (1985) criaram dois modelos básicos para a distribuição dos parâmetros granulométricos, em função da variação da energia de transporte do sedimento. São eles: a) a fração mais fina dos sedimentos da fonte seria erodida, transportada e completamente depositada, em ambiente de baixa energia, formando um depósito com sedimentos mais finos, melhor selecionados e com assimetria mais negativa em relação à área fonte; b) os sedimentos remanescentes da erosão, em ambiente de alta energia, devem apresentar granulometria mais grossa, melhor selecionamento e assimetria mais positiva quando comparado a um outro depósito considerado como fonte deste (Fig.6.1.5). Segundo os autores, a melhoria da seleção no sentido do transporte é a tendência mais universal. 


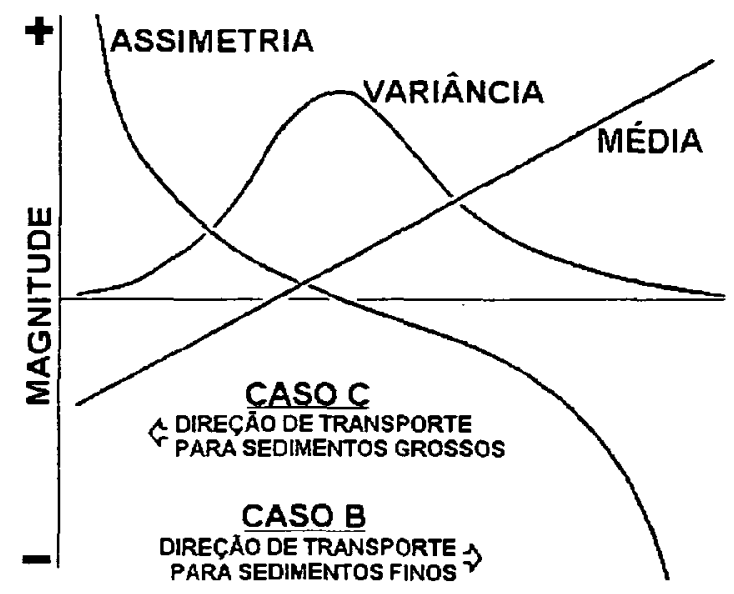

Figura 6.1.5. Sumário das mudanças nos parâmetros granulométricos $(\phi)$ que podem ocorrer numa dada direção de transporte (McLaren \& Bowles, 1985).

Alguns exemplos indicam ser o segundo modelo mais aplicável para o transporte de sedimentos pela deriva litorânea (Ruby, 1977 apud McLaren, 1981 e Bittencourt et al. 1992). Segundo Bigarella et al. (1978) o fluxo e refluxo das ondas, com capacidade desigual de transporte, produz a remoção dos sedimentos mais finos e concentração dos mais grossos. Porém, segundo Komar (1976) e Sunamura (1972 apud Taggart \& Schwartz, 1987), a remoção e transporte seletivo dos grãos, pela corrente de deriva litorânea, resulta num decréscimo do tamanho dos grãos dos sedimentos e melhoria na seleção no sentido da corrente.

A título de comparação com o modelo descrito por McLaren \& Bowles (1985), apenas a distribuição das areias na praia da Ilha do Cardoso apresentam uma tendência geral (Tabs.3.1, 3.2 e 3.3-Anexo 3) que seria representativa de uma distribuição condicionada ao efeito da deriva litorânea longitudinal para NE (Tab.6.1.4).

\begin{tabular}{|c|c|}
\cline { 2 - 2 } \multicolumn{1}{c|}{} & característica do sedimento \\
\hline \multirow{4}{*}{ Todas as praias } & mais fino \\
\cline { 2 - 2 } & assimetria mais positiva \\
\cline { 2 - 2 } Ilha do Cardoso & melhor selecionado \\
\cline { 2 - 2 } & mais grosso \\
\cline { 2 - 2 } Ilha do Superagüi & melhor selecionado \\
\cline { 2 - 2 } & mais fino \\
\cline { 2 - 2 } & melimor mais positiva \\
\hline
\end{tabular}

Tabela 6.1.4. Variação na característica dos sedimentos na direção NE. 


\subsection{Distribuição dos Minerais Pesados}

A observação da distribuição dos minerais pesados, ao longo das praias estudadas, teve por finalidade detectar a possivel concentração de minerais instáveis ou estáveis, ao longo das praias estudadas, na tentativa de se inferir o sentido do transporte de sedimentos pela corrente de deriva litorânea.

A assembléia mineralógica da fração pesada manteve-se qualitativamente constante nas três praias, havendo apenas uma certa variação na concentração dos minerais descritos. Todos os minerais encontrados apresentaram-se com grãos angulosos, exceto alguma porcentagem de zircão e turmalina que apresentaram grãos subarredondados a arredondados. Os minerais mais comuns encontrados são brevemente descritos a seguir:

-Zircão apresenta grãos incolores, alguns róseos, na maioria angulosos, ocorrendo poucos grãos arredondados;

-Turmalina é o mineral mais abundante, apresentando grãos pardos e amarelos; ocorre também a presença de grãos azuis; a forma varia de angulosa a arredondada;

-Rutilo ocorre com baixíssima concentração $(\sim 1 \%)$;

-Leucoxênio caracteriza um produto de alteração branco acinzentado da ilmenita (Deer et al., 1966) que deve ter passado pela separação por imã por já ter perdido suas propriedades magnéticas, ocorrendo apenas como mineral traço;

-Estaurolita apresenta alguns grãos com manchas negras na estrutura interna do mineral;

-Granada ocorre em algumas amostras da ilha das Peças em grãos com picoteamento; nas demais apresenta bordas lisas;

-Pistachita, do grupo dos epídotos, aparece como mineral bastante comum apresentando turvação na maioria dos grãos;

-Cianita, alguns poucos grãos de amostras da ilha do Cardoso apresentaram manchas negras na estrutura interna do mineral;

-Sillimanita apresenta em alguns grãos, manchas negras na estrutura interna do mineral; -Hornblenda;

-Hiperstênio apresenta-se, em sua maioria, com denteamento;

-Andaluzita, alguns grãos com manchas negras na estrutura interna do mineral 
Alguns minerais mais raros como monazita, scheelita e clorita tiveram sua ocorrência restrita à Ilha do Superagüi, enquanto que diopsidio foi encontrado somente na Ilha do Cardoso e barita foi encontrada nas ilhas do Cardoso e das Peças.

Da assembéia mineral encontrada nas praias estudadas, foi feita a separação entre minerais ultraestáveis, metaestáveis e instáveis, baseando-se nos trabalhos de Hubert (1971), Pettijohn (1975) e Wu (1981). Os minerais ultraestáveis correspondem ao índice ZTR, definido por Hubert (1962) como a soma das frequências percentuais de zircão, turmalina e rutilo, entre os componentes transparentes não micáceos.

\begin{tabular}{|c|c|}
\hline Estabilidade & Minerais \\
\hline \multirow{4}{*}{$\begin{array}{c}\text { ultraestáveis } \\
\text { (ZTR) }\end{array}$} & zircão \\
\cline { 2 - 2 } & turmalina \\
\cline { 2 - 2 } metaestáveis & rutilo \\
\hline \multirow{5}{*}{} & leucoxênio \\
\cline { 2 - 2 } & monazita \\
\cline { 2 - 2 } & estaurolita \\
\cline { 2 - 2 } & granada \\
\cline { 2 - 2 } & pistachita \\
\cline { 2 - 2 } & cianita \\
\cline { 2 - 2 } & opacos \\
\cline { 2 - 2 } & clorita \\
\hline \multirow{5}{*}{ instáveis } & sillimanita \\
\cline { 2 - 2 } & hornblenda \\
\cline { 2 - 2 } & diopsidio \\
\cline { 2 - 2 } & hiperstênio \\
\hline
\end{tabular}

Tabela 6.2.1. Identificação dos minerais segundo a estabilidade. Tabela baseada em Hubert (1971), Pettijohn (1975) e Wu (1981).

Tomando-se as três praias como um todo, não se observa nenhuma tendência à concentração de minerais, instáveis ou estáveis, nos extremos NE ou SW. Foi preciso portanto, considerar cada praia separadamente.

A distribuição dos minerais pesados em cada praia teve, de uma maneira geral, no sentido NE, um incremento no teor de minerais estáveis, e um decréscimo nos minerais instáveis (Anexo 1)

A distribuição do ZTR, nas amostras da Ilha do Cardoso, teve um pequeno incremento de valores no sentido NE. Dentre os minerais mais instáveis, a hornblenda e o hiperstênio tiveram uma pequena diminuição na sua concentração no sentido NE (Fig.6.2.1). 


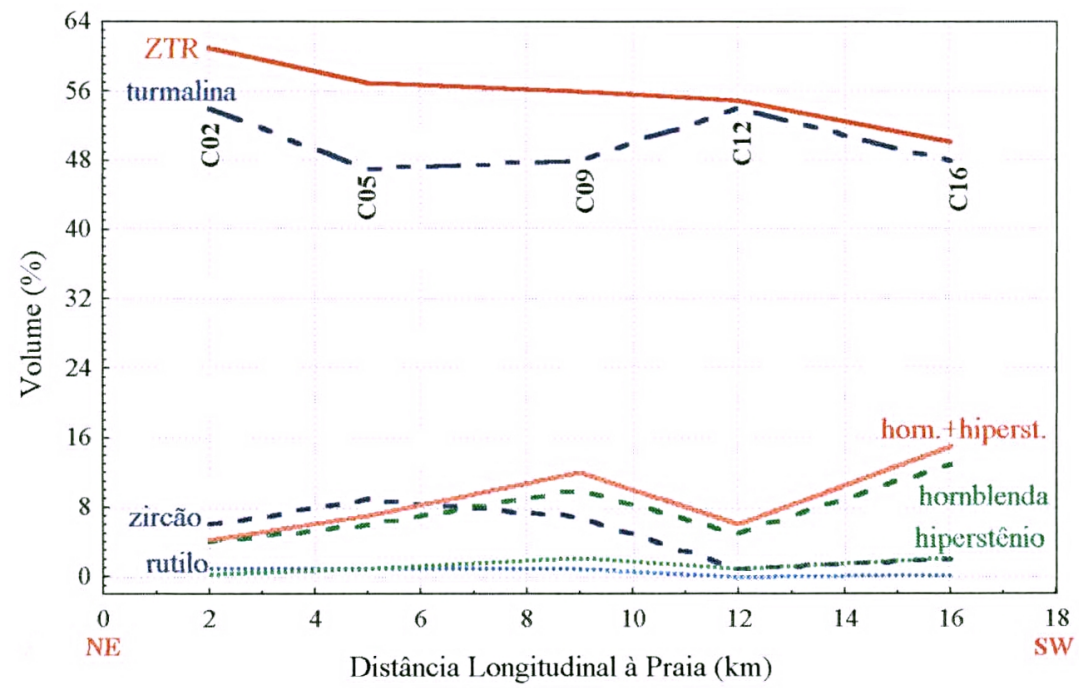

Figura 6.2.1. Gráfico de distribuição do ZTR e de alguns minerais instáveis, mais comuns nas amostras analisadas (hornblenda e hiperstênio), na praia da Iha do Cardoso. Os códigos $\mathrm{C} 02$, $\mathrm{C} 05$, etc. se referem à nomenclatura das amostras.

Na Ilha do Superagüi o índice ZTR também apresentou, como resultado final, um pequeno incremento de valores no sentido NE. Pode-se observar uma grande diminuição do índice no meio da praia, para depois voltar a crescer, porém mantendo um teor mais baixo do que no extremo SW desta (Fig. 6.2.2). A concentração da horblenda também foi decrescente, no sentido NE, apresentando apenas um súbito acréscimo no ponto mais a NE da praia, portanto mais próximo à Barra do Ararapira. Já o hiperstênio teve um decréscimo constante.

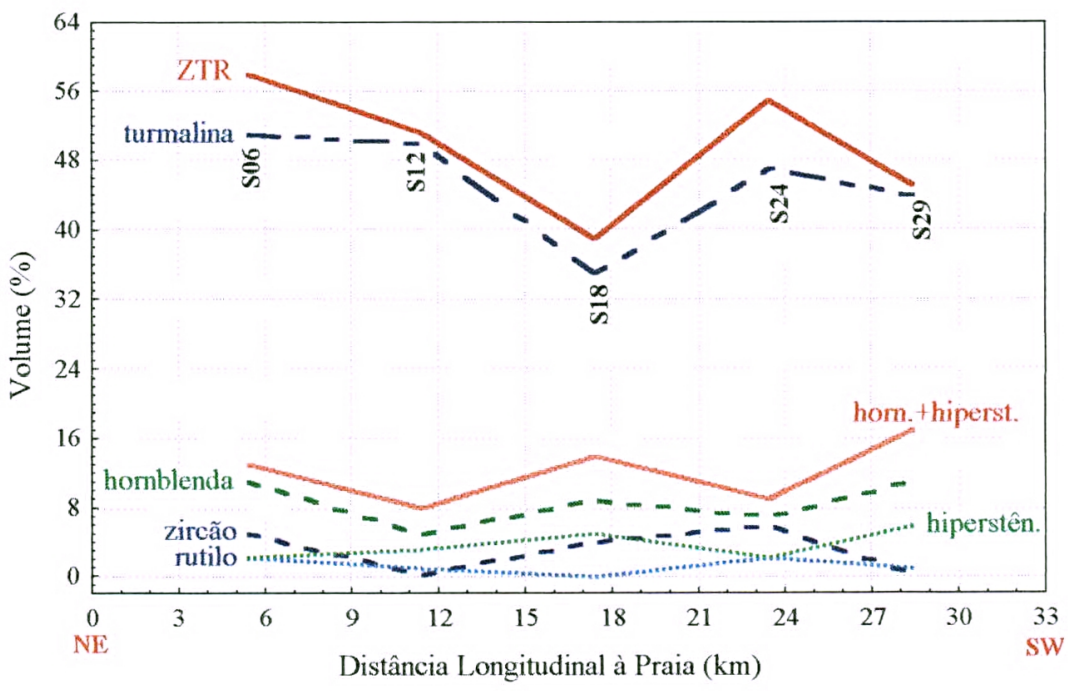

Figura 6.2.2. Gráfico de distribuição do ZTR e de alguns minerais instáveis, mais comuns nas amostras analisadas (hornblenda e hiperstênio), na praia da Ilha do Superagüi. Os códigos S06, $\mathrm{S} 12$, etc. se referem à nomenclatura das amostras. 
Na Ilha das Peças, as amostras escolhidas para a contagem e identificação dos minerais pesados estavam em pontos muito próximos. Mesmo assim, apresentaram um acréscimo de valores do índice ZTR na direção NE, apesar de uma concentração anômala de zircão no extremo SW da praia, e decréscimo na concentração dos minerais instáveis, porém com oscilações (Fig.6.2.3).

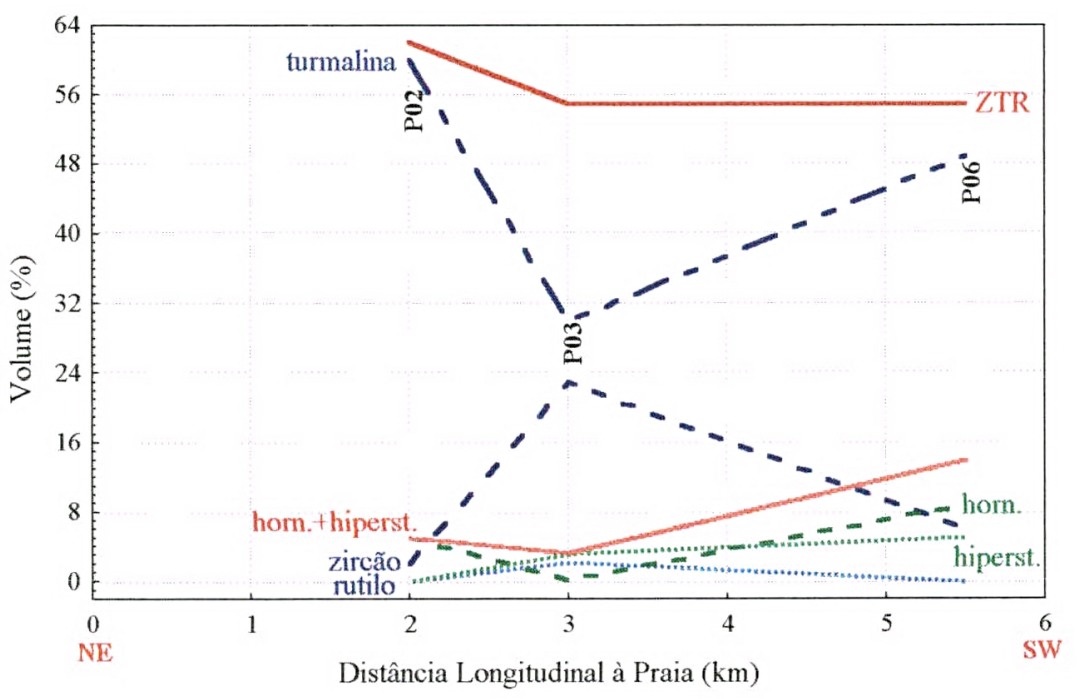

Figura 6.2.3. Gráfico de distribuição do ZTR e de alguns minerais instáveis, mais comuns nas amostras analisadas (hornblenda e hiperstênio), na praia da Ilha das Peças. Os códigos P02, P03 e P06 se referem à nomenclatura das amostras. 


\subsection{Monitoramento das margens da Barra do Ararapira}

As margens da Barra do Ararapira foram monitoradas através do levantamento de perfis, no período de setembro de 1993 a maio de 1996. Para tanto foram construídos quatro perfis na margem localizada na Ilha do Superagüi e três perfis, na margem localizada na Ilha do Cardoso (Fig.6.3.1)

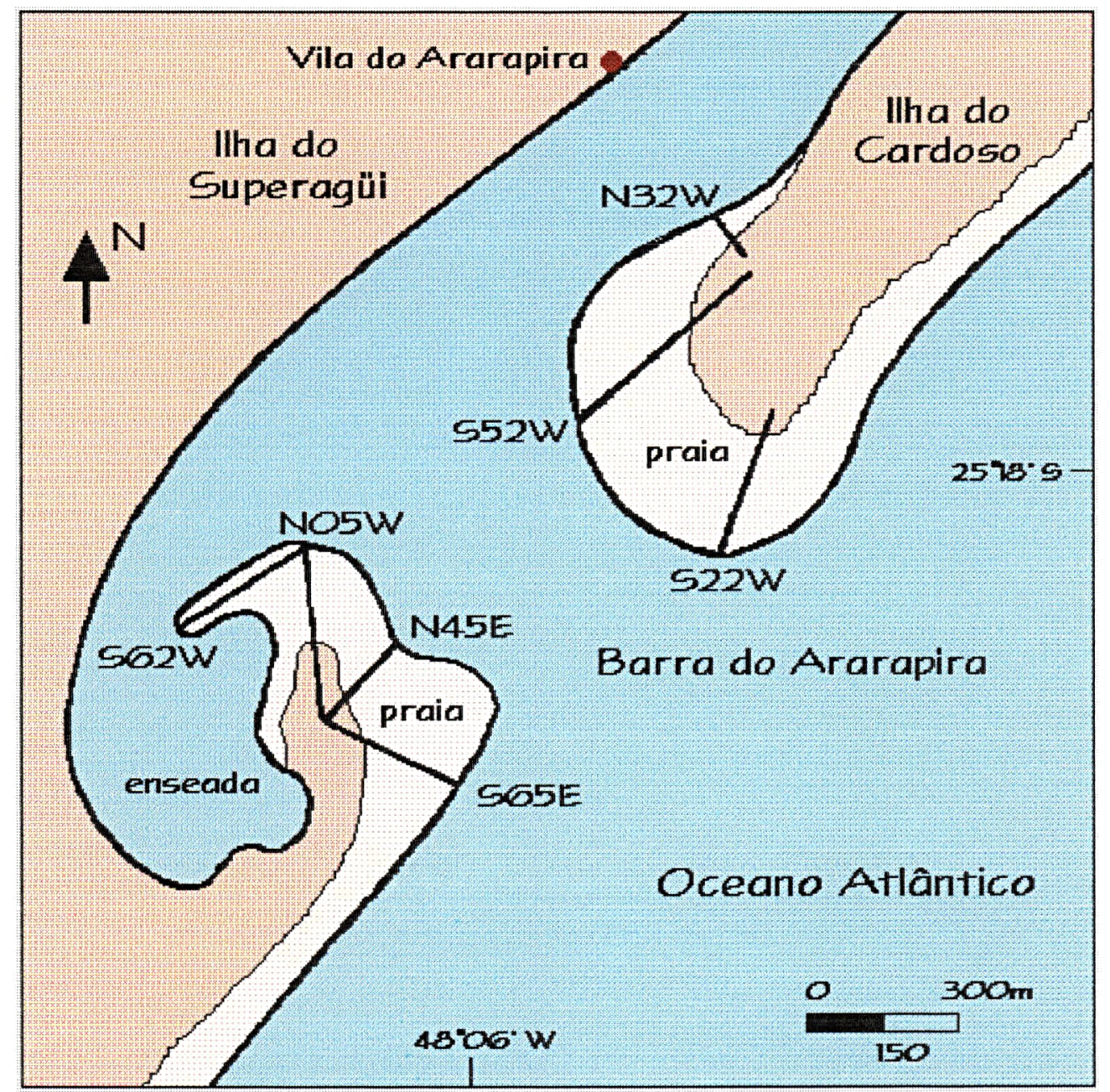

Figura 6.3.1. Mapa esquemático de localização dos perfis topográficos levantados nas margens da desembocadura lagunar do Ararapira.

No lado da Ilha do Superagüi, a margem da Barra do Ararapira assume a morfologia de um esporão recurvado. No acompanhamento da dinâmica desta margem, observou-se o crescimento de um esporão arenoso, localizado no extremo do esporão recurvado, que migrou para a porção interna da desembocadura, na direção $\mathrm{SW}$, encerrando assim, uma enseada (Foto 6.3.1-Prancha C). A evolução desta enseada torna cada vez mais estreita a faixa da 
planície costeira que une a extremidade da margem Ilha do Superagüi (esporão recurvado), onde foram levantados os perfis, com o restante da porção litorânea da ilha

Os perfis levantados na margem Ilha do Superagüi compreendem, em sua maioria, uma parte da planície costeira, recoberta por vegetação arbustiva densa, delimitada por um cordão dunar, até a antepraia.

A terminologia dos ambientes e subambientes litorâneos, utilizada para a descrição das variações morfológicas dos perfis, foi baseada no trabalho de Angulo (1996). Segundo o autor, a zona litorânea está dividida em pós-praia, antepraia e face litorânea (Fig.6.3.2). O limite entre a pós-praia e a costa são dunas ou falésias. A pós-praia apresenta declive mais acentuado e formação de bermas. O limite com a antepraia está entre o limite de espraiamento das ondas de preamar médio e o alcance máximo das ondas de tempestade ou de marés muito altas. A antepraia ocorre em seguida à pós-praia, em direção ao mar, e pode ser dividida em uma parte superior, de maior declive, denominada face praial e uma face inferior, de menor declive, com a ocorrência de canais e barras, denominada terraço de baixa-mar. A face litorânea viria em seguida à antepraia.

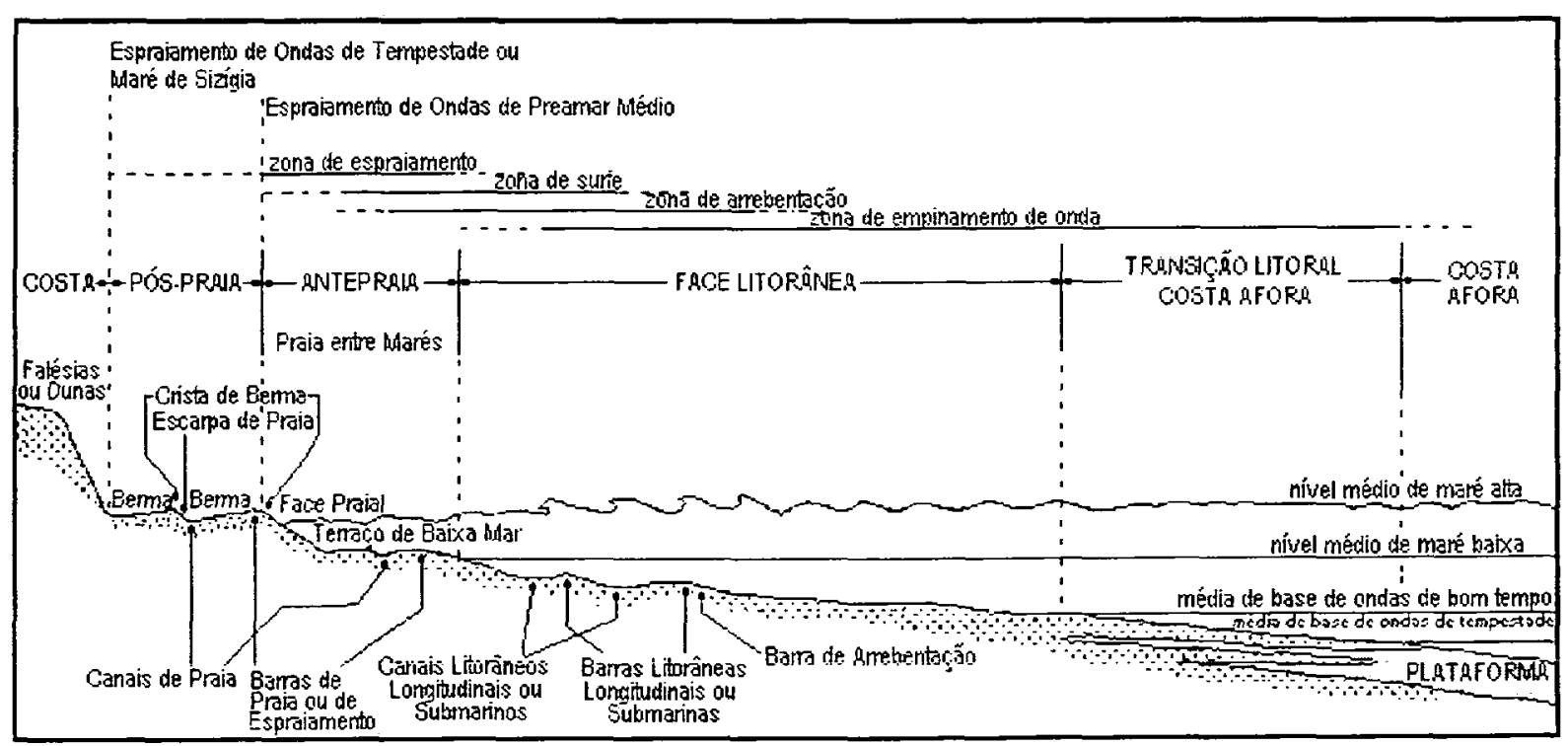

Figura 6.3.2. Perfil de ambientes e subambientes litoràneos clásticos dominados por ondas (Angulo, 1996).

$\mathrm{Na}$ margem Ilha do Cardoso os perfis abrangeram parte da planicie costeira, também recoberta por vegetação, limitada por um campo de dunas frontais, até a antepraia. Os dois 
perfis voltados para a desembocadura incluíram também, em alguns períodos, áreas parcialmente emersas, relacionadas com o delta de maré enchente.

\subsubsection{Margem Ilha do Superagüi - Série S65E}

A série de perfis com direção $\mathrm{S} 65 \mathrm{E}$, localizados na porção mais oceânica da Barra do Ararapira, do lado da Ilha do Superagüi (Fig.6.3.1), compreende uma parte da planície costeira, correspondente ao cordão dunar mais próximo à pós-praia, até a antepraia. $\mathrm{O}$ último perfil, levantado em maio de 1996, abrangeu também um canal de praia, do terraço de baixa mar.

Foi observada, através de fotos aéreas de abril de 1992, nas proximidades da área onde foi posteriormente levantada esta série de perfis, a presença de leques de sobrelavagem (Foto 6.3.1.1-Prancha C). Estes apresentam-se cortando parte dos cordões de dunas frontais e da vegetação, ambos localizados na planície costeira. A porção terminal destes leques atingiu a enseada localizada atrás do esporão recurvado que representa a margem Ilha do Superagüi.

A série de perfis levantados a partir de setembro de 1993 apresenta a seguinte sequência morfológica, em direção ao mar (Foto 6.3.1.2-Prancha C): a) cordão dunar frontal de $1,5 \mathrm{~m}$ de altura, recoberto por vegetação herbácea a arbustiva, de $50 \mathrm{~cm}$ aproximadamente; b) campo de dunas frontais, dômicas, isoladas, com altura variando de 30 a $50 \mathrm{~cm}$, apresentando vegetação rasteira esparsa; c) trecho de areias eólicas sem vegetação e d) trecho de areias úmidas.

Considerando-se o perfil como uma secção de um metro de largura, durante os três primeiros periodos de levantamentos, portanto num intervalo de 14 meses, houve a acresção de $88 \mathrm{~m}^{3}$ de areia (Tab.6.3.1.1), tanto na pós-praia quanto na antepraia.

\begin{tabular}{|c||c|c|c|c||c|}
\hline Período & $\begin{array}{c}\text { (1) set-93 } \\
\text { a dez-93 }\end{array}$ & $\begin{array}{c}\text { (2) dez-93 } \\
\text { a dez-94 }\end{array}$ & $\begin{array}{c}\text { (3) dez-94 } \\
\text { a mai-95 }\end{array}$ & $\begin{array}{c}\text { (4) mai-95 } \\
\text { a mai-96 }\end{array}$ & Total \\
\hline \hline Erosão $\left(\mathrm{m}^{3}\right)$ & - & - & 1,3 & 35,2 & 36,5 \\
\hline Acresção $\left(\mathrm{m}^{3}\right)$ & 8,2 & 43,8 & 37,9 & 1,8 & 91,7 \\
\hline
\end{tabular}

Tabela 6.3.1.1. Saldo final dos volumes de areia erodidos e acrescidos, nos períodos de levantamento dos perfis de direção S65E. para esta análise foi considerado que cada perfil tinha um metro de largura.

Analisando-se a morfologia deste trecho de praia observou-se que, durante todo o periodo de levantamentos, o cordão principal de dunas frontais manteve-se estável, com altura 
em torno de $1,5 \mathrm{~m}$, ocorrendo porém, a formação de dois novos campos de dunas frontais incipientes, em direção ao mar (Fig.6.3.1.1).

A acresção de areia observada na antepraia, durante o $1^{\underline{0}}$ período, pode ter ocorrido devido à reconstrução do perfil de verão, assumindo este uma característica mais intermediária. No $2^{\underline{o}}$ período de levantamentos observa-se a formação de uma berma na pós-praia. No período seguinte começa a se formar o $1^{\varrho}$ campo de dunas frontais (dunas primárias), em cima desta berma, que atinge uma altura aproximada de $1 \mathrm{~m}$. Ainda no $3^{0}$ período há a formação de uma segunda berma, $30 \mathrm{~m}$ à frente do cordão dunar mais jovem, que avança na antepraia. Em cima desta, no $4^{\underline{0}}$ período, forma-se outro campo de dunas primárias incipientes, de aproximadamente $30 \mathrm{~cm}$ de altura, que exibem várias marcas erosivas do tipo falésias (Foto 6.3.1.3-Prancha C). Neste último período de levantamentos há o predomínio de erosão com a retirada de $35,2 \mathrm{~m}^{3}$ de areia, podendo-se observar também, o recuo de aproximadamente $2 \mathrm{~m}$ da vegetação rasteira esparsa.

Pode-se notar, portanto, um período de acresção até aproximadamente maio de 1995 , iniciando-se em seguida um periodo com predomínio de processos erosivos. 


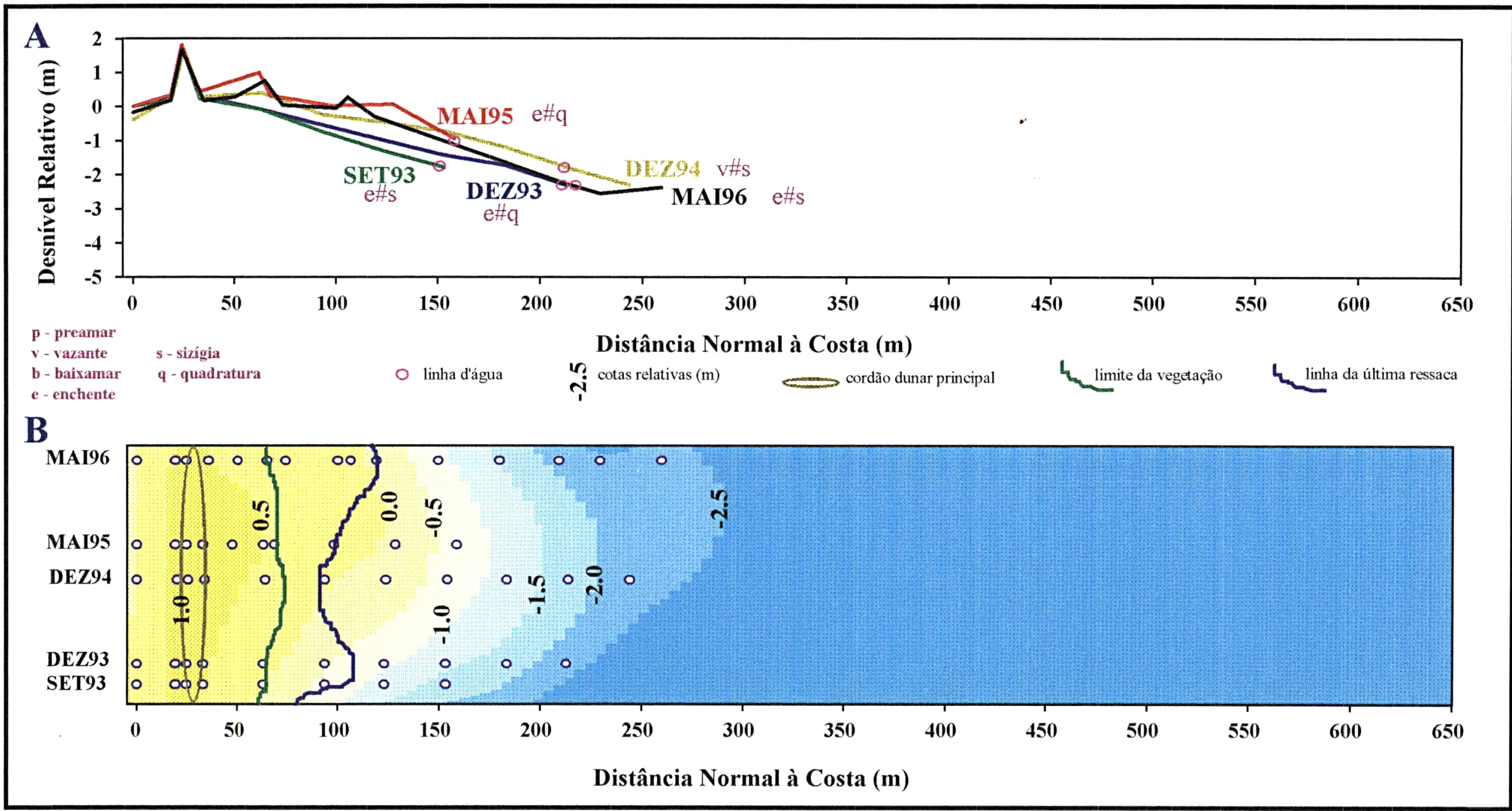

Figura 6.3.1.1. Perfis topográficos levantados na margem Ilha do Superagüi da Barra do Ararapira, com direção S65E, de setembro de 1993 a maio de 1996: (A) distância $x$ cota e (B) distância $x$ tempo $x$ cota. 


\subsubsection{Margem Ilha do Superagüi - Série N45E}

A série de perfis de direção N45E, localizada na margem Ilha do Superagüi da Barra do Ararapira está direcionada para a desembocadura (Fig.6.3.1).

Esta série abrange uma parte da planície costeira, constituída de uma porção intercordões, com vegetação arbustiva de 0,5 a 1 metro de altura, de um cordão dunar principal que acompanha a curvatura do esporão recurvado, recoberto por uma vegetação rasteira incipiente e também de um largo campo de dunas frontais, dômicas e barcanóides, isoladas, com aproximadamente $100 \mathrm{~m}$ de extensão, parcialmente recobertas por vegetação rasteira. Após o campo de dunas frontais, em direção ao mar, ocorre uma superfície plana de areias eólicas seguido de um trecho de areias úmidas da face praial da antepraia.

O $1^{0}$ período de levantamentos não foi efetuado nesta série de perfis. Considerando-se cada perfil como uma secção de um metro de largura, verificou-se, no $2^{\underline{\underline{o}}}$ período, uma acresção de $37,5 \mathrm{~m}^{3}$ de areia seguida de um periodo erosivo. Durante os dois últimos períodos observou-se uma erosão total de $168,8 \mathrm{~m}^{3}$ de areia da planície costeira (Tab.6.3.2.1).

\begin{tabular}{|c||c|c|c|c||c|}
\hline Período & $\begin{array}{c}\text { (1) set-93 } \\
\text { a dez-93 }\end{array}$ & $\begin{array}{c}\text { (2) dez-93 } \\
\text { a dez-94 }\end{array}$ & $\begin{array}{c}\text { (3) dez-94 } \\
\text { a mai-95 }\end{array}$ & $\begin{array}{c}\text { (4) mai-95 } \\
\text { a mai-96 }\end{array}$ & Total \\
\hline \hline Erosão $\left(\mathrm{m}^{3}\right)$ & $* * * * *$ & - & 53,5 & 115,3 & 168,8 \\
\hline Acresção $\left(\mathrm{m}^{3}\right)$ & $* * * * *$ & 37,5 & - & - & 37,5 \\
\hline
\end{tabular}

Tabela 6.3.2.1. Saldo final dos volumes de areia erodidos e acrescidos, nos períodos de levantamento dos perfis de direção N45E. Para esta análise foi considerado que cada perfil tinha um metro de largura.

A dinàmica deste pequeno trecho de praia mostra que o cordão dunar principal, que acompanha a curvatura da margem, manteve-se estável. Durante o $2^{\underline{0}}$ período de levantamentos observou-se a formação, no limite do campo de dunas frontais com a pós-praia, de uma linha de novas dunas primárias, com aproximadamente $0,5 \mathrm{~m}$ de altura (Fig.6.3.2.1). No $3^{\underline{a}}$ período o processo erosivo da planície costeira torna-se evidente na morfologia, através do aparecimento de pequenas falésias na base das novas dunas primárias. No $4^{0}$ período há um recuo da linha de costa, demarcado pelo recuo de $87 \mathrm{~m}$ da vegetação e do campo de dunas, com a completa destruição das dunas primárias mais jovens. Pode-se observar, neste trecho da planície costeira, constituído de dunas frontais, uma série de estruturas de sobrelavagem (Foto 6.3.2.1-Prancha C). 


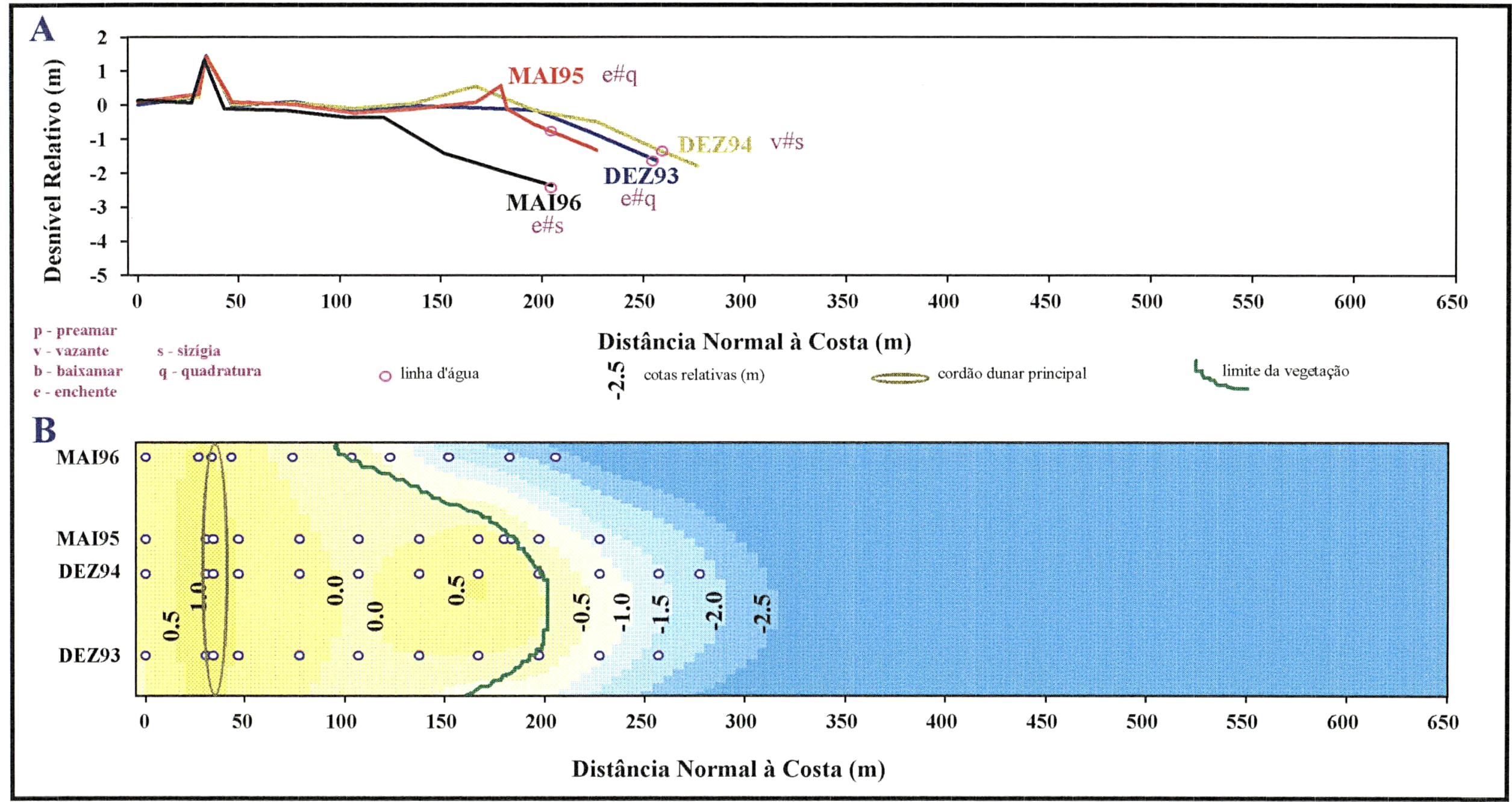

Figura 6.3.2.1. Perfis topográficos levantados na margem Ilha do Superagüi da Barra do Ararapira, com direção N45E, de dezembro de 1993 a maio de 1996: (A) distância $x$ cota e (B) distância $x$ tempo $x$ cota. 


\subsubsection{Margem Ilha do Superagüi - Série N05W}

A série de perfis de direção N05W, localizada na margem Ilha do Superagüi da Barra do Ararapira está voltada para a porção mais interior da desembocadura, próximo à enseada que se forma pelo crescimento do esporão arenoso de direção S62W (Fig.6.3.1).

Esta série de perfis abrange uma parte da planície costeira, constituida por uma área bastante vegetada com pequenas árvores e arbustos, localizada atrás do cordão dunar principal. Vizinho a este cordão, em direção ao mar, existe um campo de dunas frontais de extensão aproximada de $200 \mathrm{~m}$. A vegetação, no campo de dunas, é rasteira e torna-se escassa à medida que se aproxima da pós-praia. O campo de dunas é seguido por um campo de areias eólicas e por um trecho de areias úmidas da face praial da antepraia. $\mathrm{Na}$ pós-praia ocorre um prolongamento, para SW, de um esporão arenoso que encerra, desta maneira, uma pequena enseada.

No $1^{\underline{0}}$ periodo de levantamentos houve o abaixamento dos valores das cotas relativas dos perfis, num trecho da costa e da pós-praia, sem ocorrer alteração da posição da linha de costa. Este fato se deve à erosão de $89,1 \mathrm{~m}^{3}$ de planície costeira (Tab.6.3.3.1), considerando-se cada perfil como sendo uma secção de um metro de largura.

\begin{tabular}{|c||c|c|c|c||c|}
\hline Periodo & $\begin{array}{c}\text { (1) set-93 } \\
\text { a dez-93 }\end{array}$ & $\begin{array}{c}\text { (2) dez-93 } \\
\text { a dez-94 }\end{array}$ & $\begin{array}{c}\text { (3) dez-94 } \\
\text { a mai-95 }\end{array}$ & $\begin{array}{c}\text { (4) mai-95 } \\
\text { a mai-96 }\end{array}$ & Total \\
\hline \hline Erosão $\left(\mathrm{m}^{3}\right)$ & 56,1 & 35,4 & - & 77,4 & 168,9 \\
\hline Acresção $\left(\mathrm{m}^{3}\right)$ & 2,4 & - & 97,6 & 0,8 & 100,8 \\
\hline
\end{tabular}

Tabela 6.3.3.1. Saldo final dos volumes de areia erodidos e acrescidos, nos períodos de levantamento dos perfis de direção N05W. Para esta análise foi considerado que cada perfil tinha um metro de largura.

No $2^{-}$periodo as cotas relativas dos perfis apresentam um abaixamento de aproximadamente $30 \mathrm{~cm}$, devido à erosão de $35,4 \mathrm{~m}^{3}$ de areia na porção da planície costeira que corresponde ao campo de dunas frontais (Fig.6.3.3.1). 


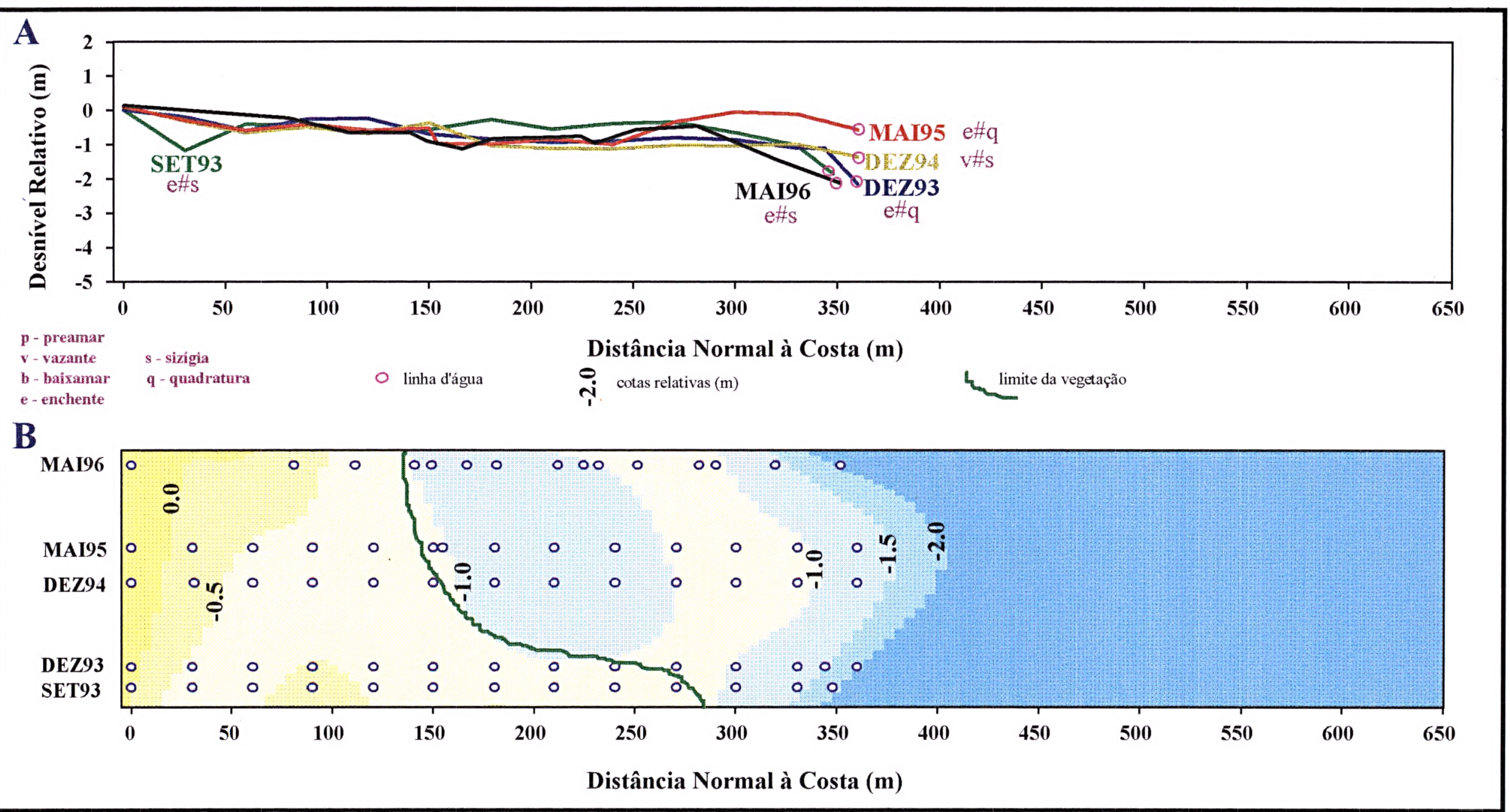

Figura 6.3.3.1. Perfis topográficos levantados na margem Ilha do Superagüi da Barra do Ararapira, com direção N05W, de setembro de 1993 a maio de 1996: (A) distância $x$ cota e (B) distância $x$ tempo $x$ cota. 
No $3^{0}$ período ocorre uma acresção de $97,6 \mathrm{~m}^{3}$ de areia principalmente na pós-praia. $\mathrm{Na}$ região do campo de dunas observa-se uma área erodida evidenciada por reentrâncias causadas pela circulação das águas na enseada, durante a preamar (Foto 6.3.3.1-Prancha C). Vários pontos das margens desta enseada apresentam evidências erosivas, como o que se pode observar na margem oposta à da localização do esporão, próximo à Vila do Ararapira. Nesta porção pôde-se observar, durante todas as etapas de campo, a queda progressiva da mata que margeia a enseada e parte do Mar do Ararapira próximo à desembocadura (Foto 6.3.3.2Prancha C).

No $4^{\circ}$ período ocorre a retomada do processo erosivo com a retirada de $76,6 \mathrm{~m}^{3}$ de areia da pós-praia. Durante este período observam-se, tanto nesta porção da praia quanto ao longo de todo o esporão, várias evidências de estruturas de sobrelavagem, retirando a vegetação e erodindo e retrabalhando o topo das dunas.

\subsubsection{Margem Ilha do Superagüi - Esporão de direção S62W}

O esporão arenoso de direção S62W está localizado no extremo interno da margem Ilha do Superagüi da Barra do Ararapira (Fig.6.3.1), iniciando-se na antepraia do perfil N05W.

Este esporão não apresenta a presença de dunas, ocorrendo apenas tufos de vegetação rasteira esparsa, que se adensou à medida que o esporão se tornou mais longo.

Nos três primeiros períodos de levantamentos foi observado um processo contínuo de aumento dos valores das cotas relativas, caracterizando uma tendência vertical de acresção de areia. O valor acrescido nestes periodos foi de $149,6 \mathrm{~m}^{3}$, considerando-se cada perfil como sendo uma secção de um metro de largura (Tab.6.3.4.1).

\begin{tabular}{|c||c|c|c|c||c|}
\hline Período & $\begin{array}{c}\text { (1) set-93 } \\
\text { a dez-93 }\end{array}$ & $\begin{array}{c}\text { (2) dez-93 } \\
\text { a dez-94 }\end{array}$ & $\begin{array}{c}\text { (3) dez-94 } \\
\text { a mai-95 }\end{array}$ & $\begin{array}{c}\text { (4) mai-95 } \\
\text { a mai-96 }\end{array}$ & Total \\
\hline \hline Erosão $\left(\mathrm{m}^{3}\right)$ & - & 3,1 & - & 64,3 & 67,4 \\
\hline Acresção $\left(\mathrm{m}^{3}\right)$ & 15,4 & 9,3 & 124,9 & - & 149,6 \\
\hline
\end{tabular}

Tabela 6.3.4.1. Saldo final dos volumes de areia erodidos e acrescidos, nos períodos de levantamento dos perfis de direçãoS62W. Para esta análise foi considerado que cada perfil tinha um metro de largura.

No $4^{\underline{0}}$ período observa-se o início de um processo erosivo, indicado através do abaixamento dos valores das cotas relativas, mesmo com o esporão apresentando-se mais longo (Fig.6.3.4.1) 


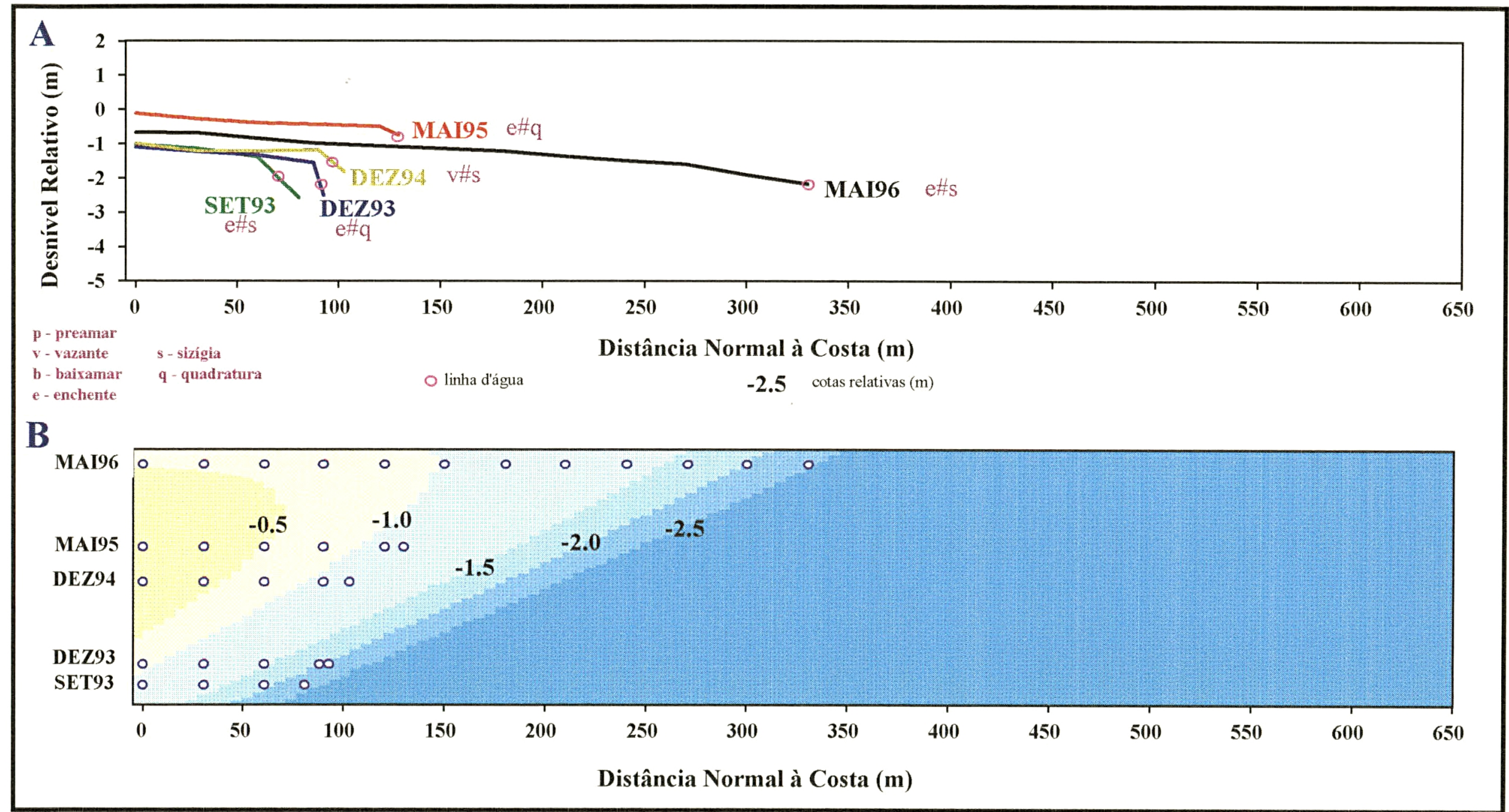

Figura 6.3.4.1. Perfis topográficos levantados na margem Ilha do Superagüi da Barra do Ararapira, com direção S62W, de setembro de 1993 a maio de 1996: (A) distância $x$ cota e (B) distância $x$ tempo $x$ cota. 


\subsubsection{Margem Ilha do Cardoso - Série N32W}

A série de perfis de direção N32W está localizada na margem Ilha do Cardoso da Barra do Ararapira, estando voltada para o interior do canal (Fig.6.3.1).

Esta série abrangeu uma parte da planície costeira, apresentando vegetação arbustiva de aproximadamente $50 \mathrm{~cm}$ de altura. Na porção próxima ao limite entre esta planície e a póspraia existe uma faixa de vegetação mais densa, arbustiva, com altura em torno de 1 a 1,5 metros. Nesta série de perfis não há a presença de cordões dunares ou campos de dunas e a pós-praia e a antepraia apresentam-se como faixas bastante estreitas, em relação às outras séries levantadas.

No $1^{\underline{0}}$ periodo de levantamentos pode-se observar a acresção de material devido à formação de uma sutil berma no limite entre a pós-praia e a antepraia. No $2^{\underline{o}}$ período, a acresção se dá devido ao desenvolvimento da berma formada no $1^{\underline{0}}$ periodo e à formação de uma segunda berma, no limite entre a faixa de vegetação arbustiva, localizada na planície costeira e a pós-praia. Estas duas etapas mostram um periodo acrescional, com aumento de $25,2 \mathrm{~m}^{3}$ no volume de areia da pós-praia, considerando-se cada perfil como uma secção de um metro de largura (Tab.6.3.5.1).

\begin{tabular}{|c||c|c|c|c||c|}
\hline Periodo & $\begin{array}{c}\text { (1) set-93 } \\
\text { a dez-93 }\end{array}$ & $\begin{array}{c}\text { (2) dez-93 } \\
\text { a dez-94 }\end{array}$ & $\begin{array}{c}\text { (3) dez-94 } \\
\text { a mai-95 }\end{array}$ & $\begin{array}{c}\text { (4) mai-95 } \\
\text { a mai-96 }\end{array}$ & Total \\
\hline \hline Erosão $\left(\mathrm{m}^{3}\right)$ & 1,3 & - & 6,5 & 29,8 & 37,6 \\
\hline Acresção $\left(\mathrm{m}^{3}\right)$ & 2,9 & 22,3 & - & 5,7 & 30,9 \\
\hline
\end{tabular}

Tabela 6.3.5.1. Saldo final dos volumes de areia erodidos e acrescidos, nos periodos de levantamento dos perfis de direçãoN32W. Para esta análise foi considerado que cada perfil tinha um metro de largura.

No $3^{\circ}$ período pode-se observar a suavização do perfil praial, com a erosão e retrabalhamento das areias das bermas da pós-praia (Fig.6.3.5.1).

No último periodo de levantamentos foi observada a formação de uma falésia de cerca de $60 \mathrm{~cm}$ de altura, cortando o perfil praial na altura do limite entre a planície costeira e a póspraia, destruindo parte da vegetação arbustiva e causando a retirada de aproximadamente $30 \mathrm{~m}^{3}$ de areia (Foto 6.3.5.1-Prancha C).

Nota-se então, nesta série de perfis, o predomínio do processo de acresção até dezembro de 1994, iniciando-se a partir de então um processo erosivo. 


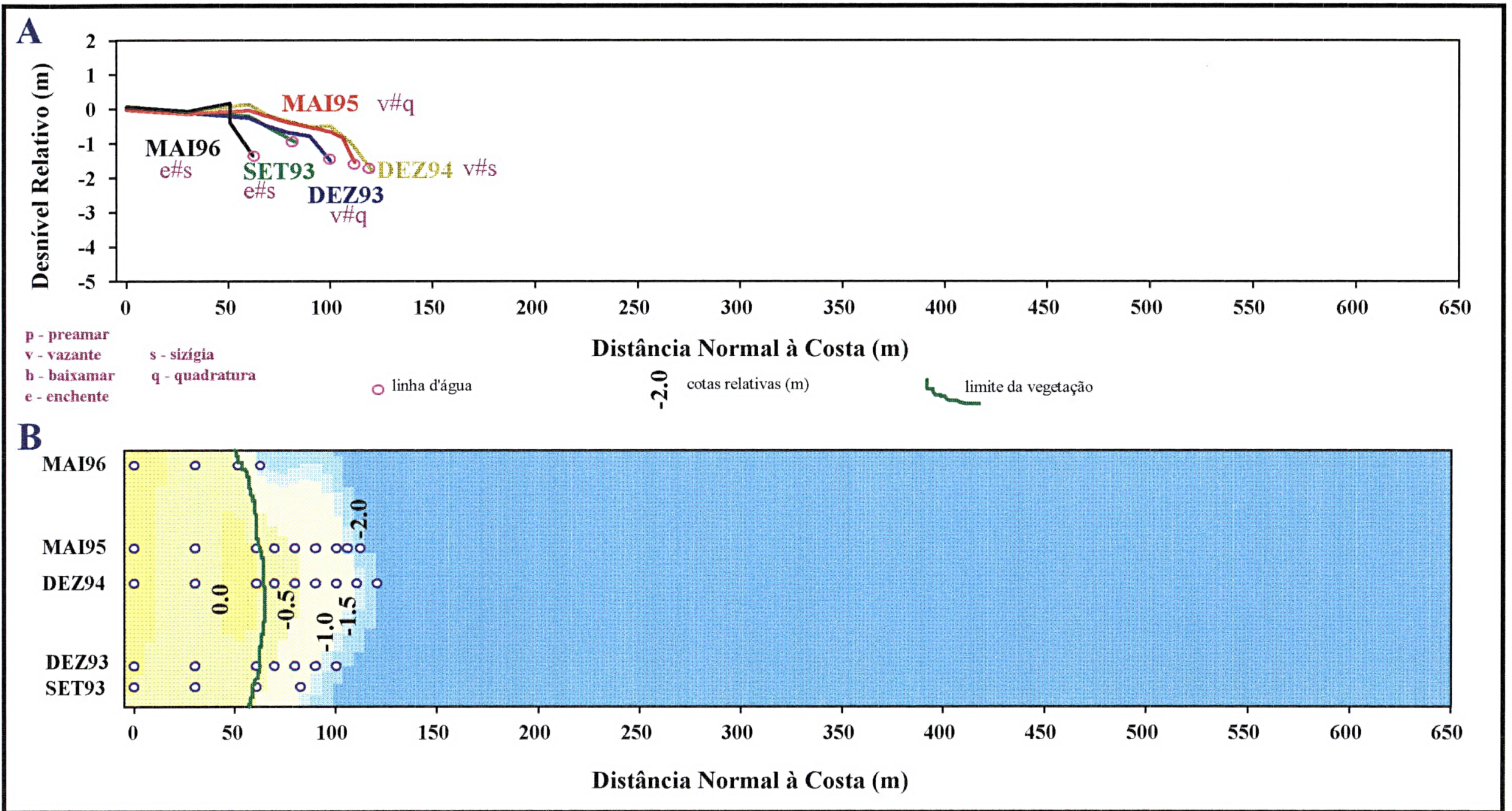

Figura 6.3.5.1. Perfis topográficos levantados na margem Ilha do Cardoso da Barra do Ararapira, com direção N32W, de setembro de 1993 a maio de 1996: (A) distância $x$ cota e (B) distância $x$ tempo $x$ cota. 


\subsubsection{Margem Ilha do Cardoso - Série S52W}

A série de perfis de direção S52W está localizada na margem Ilha do Cardoso da Barra do Ararapira, direcionada para a desembocadura (Fig.6.3.1).

Esta série de perfis abrange parte da planicie costeira, constituida de uma faixa recoberta por vegetação rasteira densa, delimitada por um cordão de dunas frontais. O cordão de dunas frontais é seguido, em direção ao mar, de um trecho de areias eólicas e outro de areias úmidas. Alguns perfis abrangeram também canais e barras de praia do terraço de baixa mar e sequèncias de dunas subaquosas, relacionadas ao delta de maré enchente.

No perfil levantado em setembro de 1993 observou-se a existência de uma microfalésia no limite entre a vegetação rasteira e a pós-praia. Neste mesmo local, em dezembro de 1993, observou-se a formação de um cordão de dunas frontais de aproximadamente $50 \mathrm{~cm}$ de altura, que se manteve presente durante todos os periodos seguintes de levantamentos.

Nos perfis do $2^{\underline{o}}$ período observou-se uma extensa série de feições deposicionais relacionadas, principalmente, com o delta de maré enchente. Por exemplo, no perfil de dezembro de 1993, existe uma sequência de aproximadamente $280 \mathrm{~m}$ de extensão de dunas subaquosas direcionadas para o interior do canal (Foto 6.3.6.1-Prancha C). Já no perfil de dezembro de 1994, esta sequência inicia-se 170m mais adiante (Fig.6.3.6.1), decorrente de uma acresção de $3,5 \mathrm{~m}^{3}$ de areia (Tab.6.3.6.1), considerando-se cada perfil como uma secção de um metro de largura. Nos últimos $40 \mathrm{~m}$ deste perfil as dunas subaquosas estão direcionadas para a desembocadura, no sentido da maré vazante.

\begin{tabular}{|c||c|c|c|c||c|}
\hline Período & $\begin{array}{c}\text { (1) set-93 } \\
\text { a dez-93 }\end{array}$ & $\begin{array}{c}\text { (2) dez-93 } \\
\text { a dez-94 }\end{array}$ & $\begin{array}{c}\text { (3) dez-94 } \\
\text { a mai-95 }\end{array}$ & $\begin{array}{c}\text { (4) mai-95 } \\
\text { a mai-96 }\end{array}$ & Total \\
\hline \hline Erosão $\left(\mathrm{m}^{3}\right)$ & 5,8 & 0,4 & 14,8 & - & 21,0 \\
\hline Acresção $\left(\mathrm{m}^{3}\right)$ & 10,2 & 3,5 & 2,7 & 337,5 & 353,9 \\
\hline
\end{tabular}

Tabela 6.3.6.1. Saldo final dos volumes de areia erodidos e acrescidos, nos períodos de levantamento dos perfis de direçãoS52W. Para esta análise foi considerado que cada perfil tinha um metro de largura.

O $3^{0}$ periodo de levantamentos apresenta um periodo de erosão da antepraia e póspraia, com a retirada de um volume de $14,8 \mathrm{~m}^{3}$ de areia. 


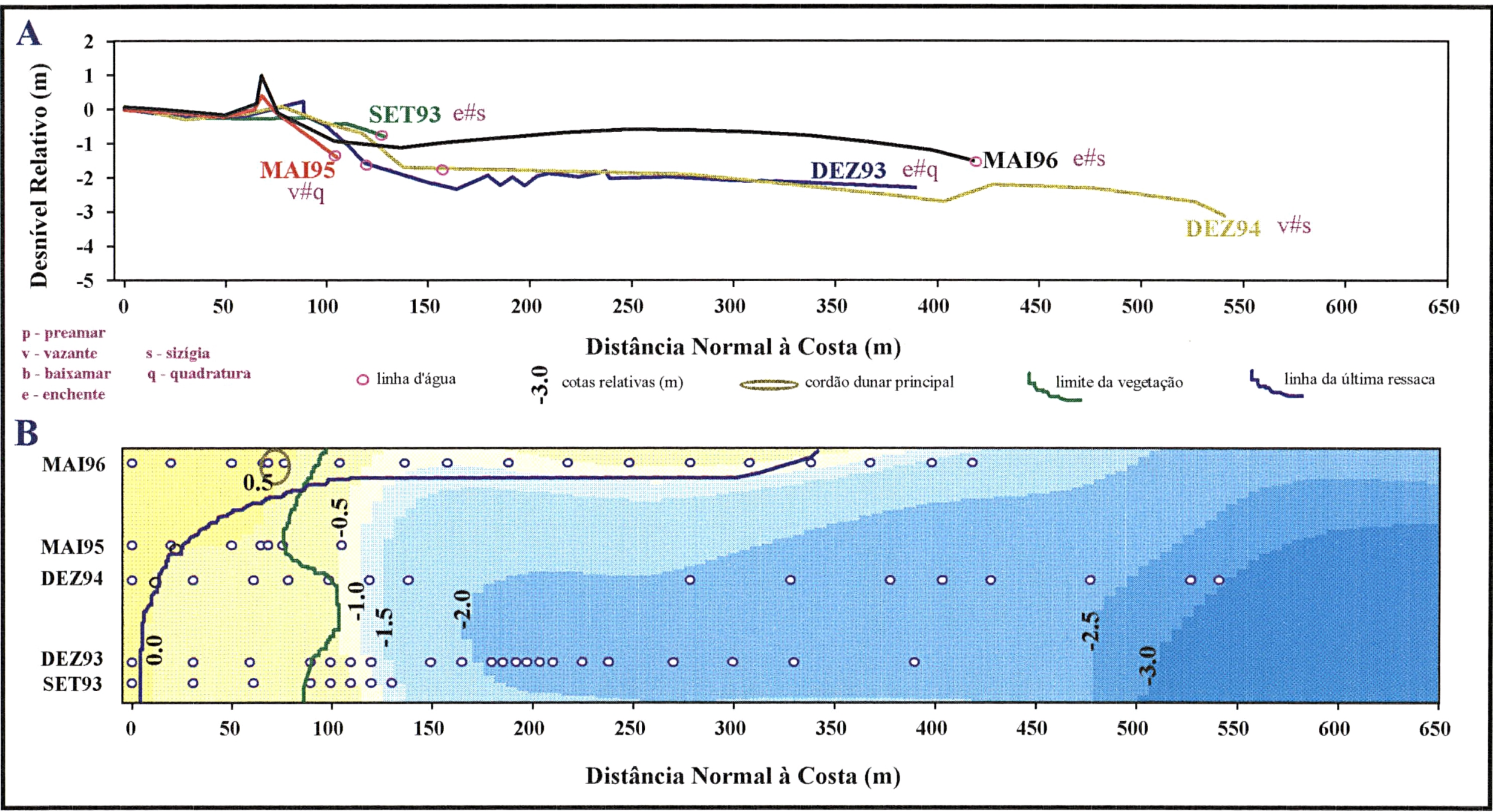

Figura 6.3.6.1. Perfis topográficos levantados na margem Ilha do Cardoso da Barra do Ararapira, com direção S52W, de setembro de 1993 a maio de 1996: (A) distância $x$ cota e (B) distância $x$ tempo $x$ cota. 
Na última etapa pôde-se observar a existência de um canal longitudinal, de escoamento da maré, com marcas onduladas, localizado na antepraia. Observou-se ainda uma acresção de $337,5 \mathrm{~m}^{3}$ de areia na área seguinte a este canal, em direção ao mar, onde antes apareciam marcas onduladas, pertencentes ao terraço de baixa mar da antepraia e agora, começam a aparecer tufos de uma vegetação rasteira. Esta vegetação serve de obstáculo para as areias eólicas, iniciando-se assim, um processo de construção de pequenas dunas, com aproximadamente $10 \mathrm{~cm}$ de altura (Foto 6.3.6.2-Prancha $\mathrm{C}$ ). Este campo de pequenas dunas, escassamente vegetadas, espalha-se por uma faixa de extensão aproximada de $150 \mathrm{~m}$. O perfil levantado em maio de 1996 apresentou também um avanço de aproximadamente $15 \mathrm{~m}$ da vegetação rasteira na pós-praia.

Esta série de perfis, por apresentar a maior taxa de deposição encontrada nesta margem, representaria a direção mais próxima da direção preferencial de avanço da margem NE da Barra do Ararapira.

\subsubsection{Margem Ilha do Cardoso - Série S22W}

A série de perfis de direção S22W está localizada na margem Ilha do Cardoso da Barra do Ararapira. Esta série também está direcionada para a desembocadura, porém para uma porção mais voltada para o mar aberto (Fig.6.3.1).

Os perfis desta série abrangem um cordão dunar principal, de um campo de dunas frontais, de aproximadamente $1 \mathrm{~m}$ de altura que, no início dos levantamentos, apresenta-se recoberto por vegetação esparsa, tornando-se esta mais desenvolvida até o final dos trabalhos de campo. Abrange também a pós-praia e a antepraia, que também apresentam uma evolução, tanto na formação de campos de dunas, inicialmente inexistentes, quanto na vegetação, que se desenvolveu e avançou em direção ao mar. Alguns perfis abrangeram também, terraços de baixa mar com canais de praia, parcialmente emersos. Nesta série de perfis pode-se notar que o processo atuante é o de acresção.

Nos dois perfis do $1^{\underline{0}}$ período de levantamentos, observou-se uma falésia de aproximadamente $70 \mathrm{~cm}$ de altura cortando o cordão dunar principal. Este, nos periodos seguintes, foi reconstruído e manteve-se estável e coberto de vegetação. Nos dois primeiros periodos houve uma acresção de $27,3 \mathrm{~m}^{3}$ de areia na antepraia (Tab.6.3.7.1), considerando-se o perfil como uma secção de um metro de largura. 


\begin{tabular}{|c||c|c|c|c||c|}
\hline Periodo & $\begin{array}{c}\text { (1) set-93 } \\
\text { a dez-93 }\end{array}$ & $\begin{array}{c}\text { (2) dez-93 } \\
\text { a dez-94 }\end{array}$ & $\begin{array}{c}\text { (3) dez-94 } \\
\text { a mai-95 }\end{array}$ & $\begin{array}{c}\text { (4) mai-95 } \\
\text { a mai-96 }\end{array}$ & Total \\
\hline \hline Erosão $\left(\mathrm{m}^{3}\right)$ & - & - & 6,4 & 2,2 & 8,6 \\
\hline Acresção $\left(\mathrm{m}^{3}\right)$ & 9,3 & 18,0 & 73,0 & 156,6 & 256,9 \\
\hline
\end{tabular}

Tabela 6.3.7.1. Saldo final dos volumes de areia erodidos e acrescidos, nos periodos de levantamento dos perfis de direçãoS22W. Para esta análise foi considerado que cada perfil tinha um metro de largura.

O $3^{0}$ periodo foi caracterizado pela acresção de $73 \mathrm{~m}^{3}$ de areia na pós-praia e face praial da antepraia, através do aumento no valor das cotas relativas, caracterizando então, uma tendência vertical de acresção (Fig. 6.3.7.1). Pôde-se observar também a formação de um segundo cordão de dunas frontais (dunas primárias) de aproximadamente $50 \mathrm{~cm}$ de altura, acompanhado de um avanço de $23,2 \mathrm{~m}$ da vegetação arbustiva, com $30 \mathrm{~cm}$ de altura. Do limite deste novo cordão dunar, em direção ao mar, formou-se um campo de dunas primárias recentes, de $30 \mathrm{~cm}$ de altura, parcialmente recoberto por vegetação rasteira. Neste período, pôde-se observar ainda, um avanço de aproximadamente $15 \mathrm{~m}$ do terraço de baixa mar, rico em marcas onduladas produzidas por correntes provenientes de ESE, portanto da corrente de maré enchente.

No último período de levantamentos observou-se a formação de um terceiro cordão de dunas frontais (dunas primárias) de $60 \mathrm{~cm}$ de altura, um pouco além do limite do campo de dunas frontais recentes (Fotos 6.3.7.1 e 6.3.7.2-Prancha C). Houve também um avanço de $40 \mathrm{~m}$ da vegetação arbustiva e de $20 \mathrm{~m}$ da rasteira. O volume total de areia acrescido foi de $156,6 \mathrm{~m}^{3}$, principalmente no terraço de baixa mar, onde marcas onduladas dão lugar a uma planicie de aproximadamente $100 \mathrm{~m}$ recoberta por um tapete de areias eólicas, a $200 \mathrm{~m}$ da origem do perfil levantado em maio de 1996. 


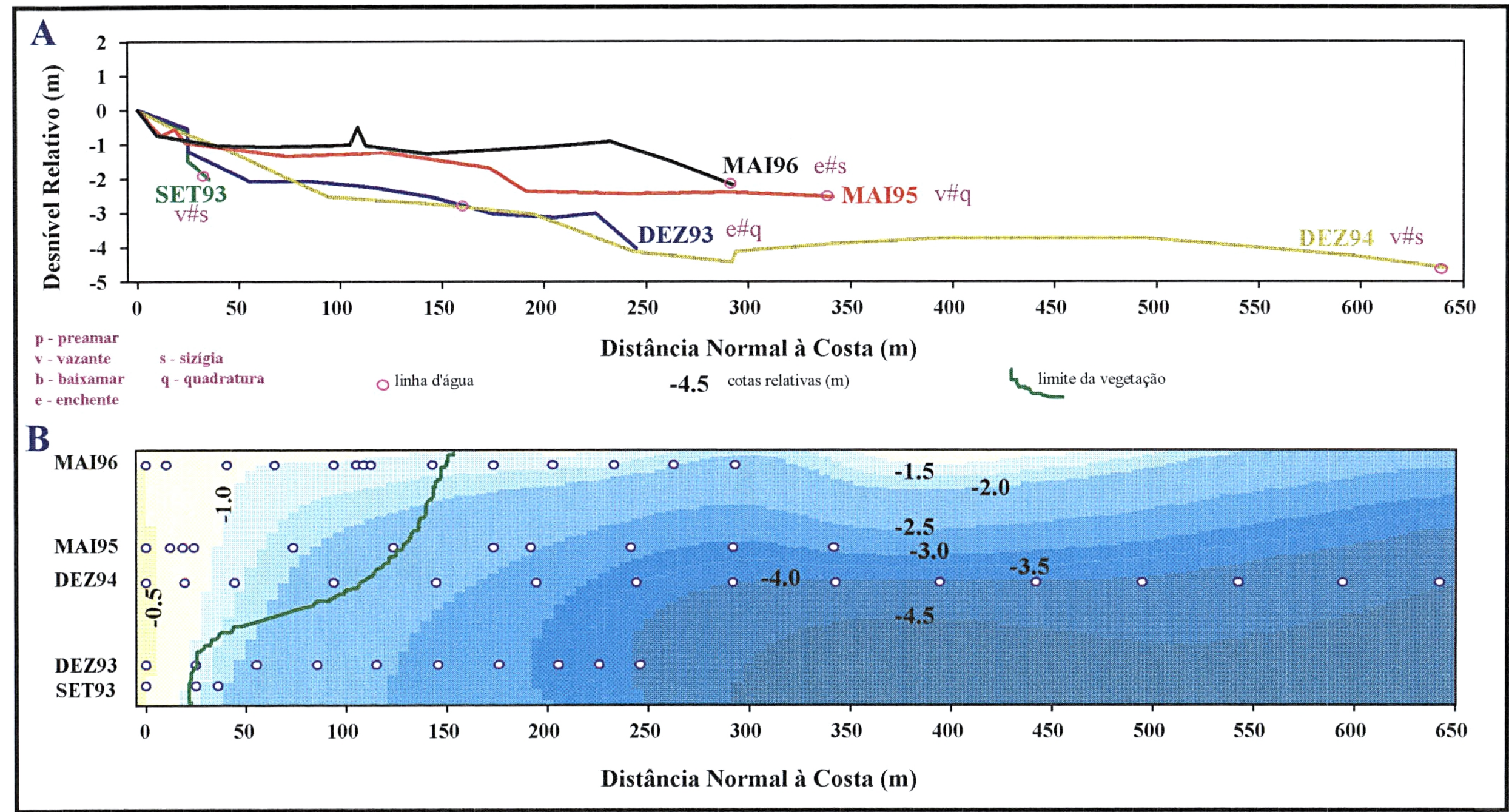

Figura 6.3.7.1. Perfis topográficos levantados na margem Ilha do Cardoso da Barra do Ararapira, com direção S22W, de setembro de 1993 a maio de 1996: (A) distância $x$ cota e (B) distância $x$ tempo $x$ cota 


\subsection{Considerações sobre a variação topográfica das margens da Barra do Ararapira}

Alguns perfis mantiveram, durante todos os períodos analisados, a constância do processo erosivo ou de acresção, enquanto outros demonstraram alternância de processos

Analisando-se, conjuntamente, os perfis da margem Ilha do Superagüi, pode-se observar que o perfil voltado para o lado oceânico (S65E) apresentou, nos três primeiros períodos, acresção de areia e no último, erosão. A acresção ocorre, provavelmente, pelo bloqueio dos sedimentos transportados pela corrente de deriva litorânea longitudinal, causado pela descarga da maré vazante na desembocadura do Ararapira, funcionando como um molhe hidráulico. Ou pode ocorrer simplesmente, devido às variações hidrodinâmicas relacionadas, principalmente, à altura, período e ângulo de ataque das ondas às praias oceânicas expostas ou abrigadas. Enquanto isso, no perfil voltado para a desembocadura (N45E), houve o predomínio do processo erosivo, por estar esta margem, sob ação da corrente de maré vazante, que causa a retirada de sedimentos, como na margem côncava de um meandro.

No perfil mais interno da margem Ilha do Superagüi (N05W), observou-se que os valores de erosão são devido ao avanço da enseada em direção ao esporão recurvado que caracteriza esta margem. Este fato ocorre devido à retirada de areia da porção mediana do perfil. Isto ocorre em periodos de maré alta em conseqüência à circulação das águas dentro da enseada. Por outro lado, a porção mais distal do perfil manteve-se praticamente constante até o $4^{\underline{0}}$ período de medições, quando se observou o início de um período erosivo.

O que se nota então é que, à medida que o perfil voltado para a desembocadura é erodido, há o recuo da linha de costa e o efeito meandro, ou seja, a corrente de maré vazante, começa a atuar também nos dois perfis adjacentes, o voltado para o oceano e o voltado para o interior, pois ocorre a instalação do processo erosivo nestes dois perfis adjacentes, somente durante o $4^{\underline{0}}$ periodo.

O perfil mais interno da margem Ilha do Cardoso $(\mathrm{N} 32 \mathrm{~W})$ apresentou um processo erosivo no último período de levantamentos, devido provavelmente, à proximidade deste a um dos meandros, localizados no esporão do Ararapira, que margeiam o corpo lagunar. Os dois perfis voltados para a desembocadura ( $52 \mathrm{~W}$ e $\mathrm{S} 22 \mathrm{~W}$ ), apresentaram o predomínio de processos acrescionais. Pode-se observar que o avanço desta margem é acelerado pela 
coalescência da sua face praial com o que corresponderia ao delta de maré enchente (Foto 6.4.1-Prancha C).

O delta está localizado próximo à margem e assume uma morfologia semelhante a uma barra em pontal da margem convexa de um sistema meandrante. Neste sistema é típico o padrão de circulação helicoidal (em redemoinho) (Fig.6.4.1) que produz uma componente normal à margem côncava do canal, fazendo erodir esta perto da superficie e depositar próximo ao fundo (Davis, 1983). Na margem convexa, a diminuição da velocidade e profundidade e a componente vertical de velocidade para cima causam um stress tangencial e a superficie funciona como um decantador (Reading, 1978).
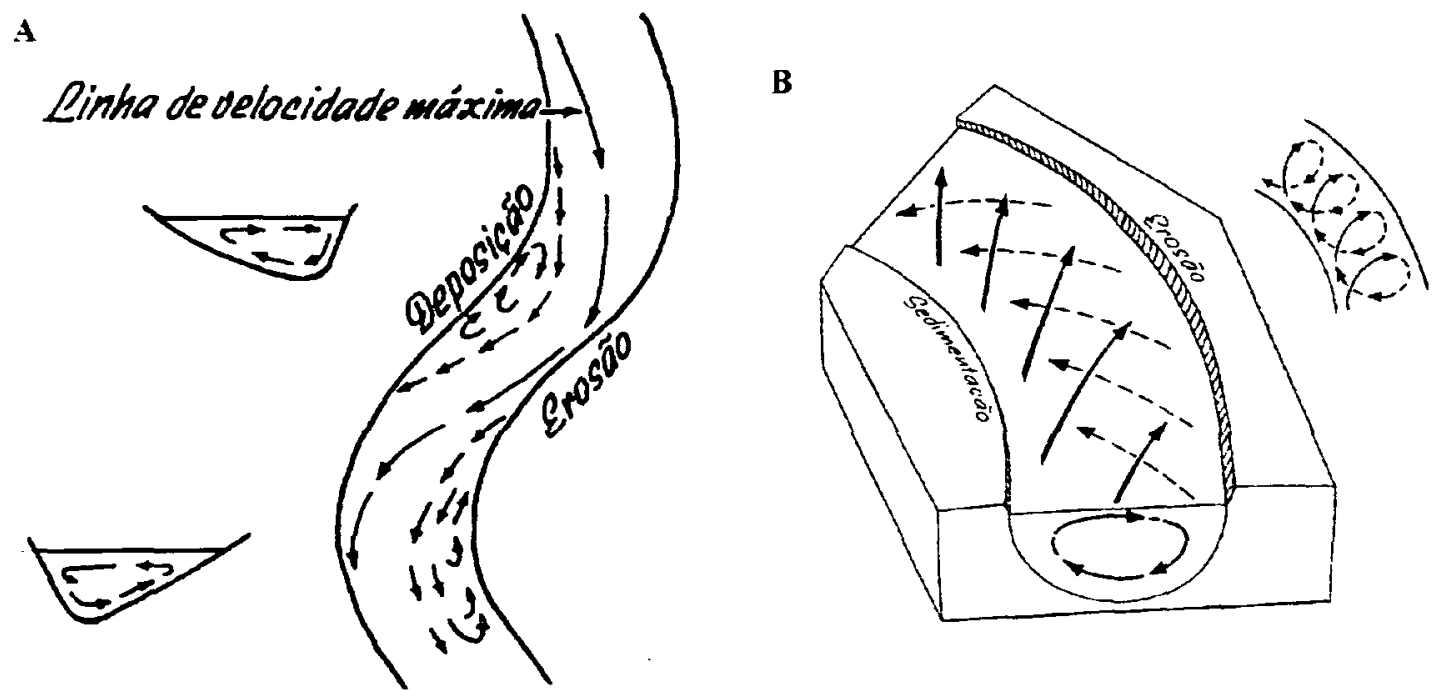

Figura 6.4.1. A. Esquema ilustrativo dos padrões de fluxo em meandros; B. fluxo helicoidal numa curva de meandro; sentido do movimento de água na superficie (seta cheia) e no fundo (seta interrompida) (Suguio \& Bigarella, 1979).

Considerando-se um balanço final dos valores erodidos e acrescidos em cada perfil, de ambas as margens (Tab.6.4.1), o que se nota é que, na margem Ilha do Cardoso há o predominio relativamente contínuo de acresção, em praticamente toda a extensão da margem, durante todos os periodos de acompanhamento. Enquanto que a margem Ilha do Superagüi apresentou, num mesmo perfil, alternância de processos erosivos e de acresção, portanto o processo erosivo não é tão contínuo como na margem oposta. Não há uma erosão uniforme em todos os locais da margem. 


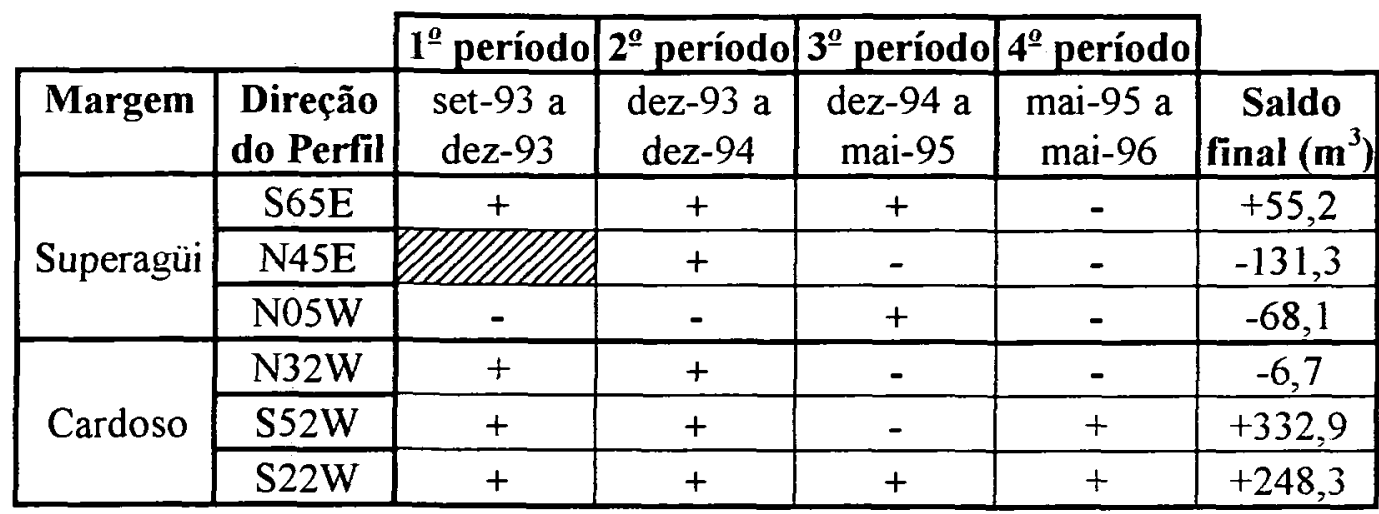

Tabela 6.4.1. Balanço dos volumes erodidos e acrescidos nas margens Ilha do Superagüi e do Cardoso, da Barra do Ararapira. O sinal $(+)$ representa o predomínio de acresção de areia no perfil e o sinal $(-)$, o predomínio de erosão. O saldo final corresponde à somatória dos volumes de areia erodidos e acrescidos no perfil, durante as quatro etapas (período compreendido entre setembro de 1993 e maio de 1996), considerando-se o perfil como uma secção de um metro de largura.

\subsection{Monitoramento dos estreitos no esporão do Ararapira}

O esporão do Ararapira apresenta três estreitamentos, sendo que o recuo de dois deles foi acompanhado durante o período de levantamentos dos perfis nas margens da Barra do Ararapira. Estes estreitamentos estão localizados nas margens côncavas dos suaves meandros que delineiam o corpo lagunar do Ararapira (Foto 6.5.1-Prancha C).

O estreito do Ponto 3 (Fig.4.2.1.1 e Foto 6.5.2-Prancha C), que foi monitorado em três pontos, apresentou uma diminuição significativa em sua largura (Tab.6.5.1), decorrente da erosão da falésia existente na margem do corpo lagunar (Foto 6.5.3-Prancha C).

\begin{tabular}{|c||c|c|c||c|}
\hline $\begin{array}{c}\text { Recuo da } \\
\text { margem }(\mathrm{m})\end{array}$ & $\begin{array}{c}\text { ponto3 } \\
\text { perfil A }\end{array}$ & $\begin{array}{c}\text { ponto 3 } \\
\text { perfil B }\end{array}$ & $\begin{array}{c}\text { ponto 3 } \\
\text { perfil C }\end{array}$ & $\begin{array}{c}\text { estreito do } \\
\text { ponto 4 }\end{array}$ \\
\hline \hline set-93 a dez-93 & $\begin{array}{c}\text { não } \\
\text { erodiu }\end{array}$ & $\begin{array}{c}+0.4 \text { (dunas na } \\
\text { face de praia) }\end{array}$ & $\begin{array}{c}\text { não } \\
\text { erodiu }\end{array}$ & $* * * * *$ \\
\hline dez-93 a dez-94 & 0,9 & 2,9 & 1,3 & 1,3 \\
\hline dez-94 a mai-95 & 6,9 & 2,2 & 2,6 & 1,1 \\
\hline mai-95 a mai-96 & 2,5 & 1,0 & 2,9 & 0,7 \\
\hline erosão total & 10,3 & 5,7 & 6,8 & 3,1 \\
\hline largura inicial & 47 & 43,3 & 41,5 & \\
\hline largura final & 36,7 & 37,6 & 34,7 & \\
\hline
\end{tabular}

Tabela 6.5.1. Valores de recuo da falésia nos pontos 3 e 4 (Fig.3.1.1) dos estreitos do esporão do Ararapira. Obs. Entende-se por largura do estreito a distância entre a falésia da margem do canal e o cordão de dunas frontais junto à linha de costa, no lado oceânico. 
Considerando-se a largura do estreito como sendo a distância entre a falésia que margeia o corpo lagunar e o cordão dunar que limita a linha de costa do lado oceânico, temos uma largura inicial média de $44 \mathrm{~m}$. Sendo assim, este estreito teve sua largura diminuida em $18 \%$, num período de dois anos e oito meses.

O estreito do ponto 4 (Fig.4.2.1.1) possui uma largura superior, porém foi observada sua evolução por se localizar próximo à desembocadura do canal do Varadouro (Foto 6.5.4Prancha $\mathrm{C}$ ), o que poderia ser um fator acelerador de um processo erosivo desta margem. $\mathrm{O}$ recuo total da margem no ponto 4 foi de $3,1 \mathrm{~m}$, num período de dois anos e quatro meses.

Nota-se que, levando em conta os valores de taxas de erosão vs tempo, o maior período erosivo esteve compreendido entre dezembro de 1994 e maio de 1995. 


\section{7 - DISCUSSÃO}

Analisando-se as características do regime de ondas, compilada em dados da literatura (Portobrás, 1983), o que se pode observar de mais interessante para compreender os processos geológicos estudados é a existência clara de dois padrões de onda, que induzem a dois sentidos inversos de correntes de deriva litorânea. Este fenòmeno torna-se mais evidente quando se identifica o padrão de distribuição dos sedimentos praiais e a dinàmica da Barra do Ararapira.

As ondas provenientes de SE, formadas pela ação dos ventos durante a passagem de frentes frias, incluindo o que poderia ser chamado de ondas de tempestade, induzem correntes de deriva litorànea bastante fortes rumo a NE, predominando então, na Barra do Ararapira, a erosão da margem a montante da desembocadura e acresção na margem a jusante. Este fato causa a migração da desembocadura rumo a SW.

Porém, quando ocorrem épocas prolongadas de ausência dos ventos provenientes do quadrante sul, as ondas que se formam provém de ENE, induzidas por ventos associados à Alta do Atlântico Sul. A essas ondas simétricas ou crescentes denominam-se vagas. Este padrão de ondas que se forma não tem tanta energia quanto as ondas provenientes de SE, porém se há o predomínio deste por um tempo prolongado, deve haver uma inversão temporária no sentido da corrente de deriva litorânea. Quando isto ocorre, a migração da barra se dá pela acresção na margem à montante da desembocadura, em relação ao sentido da corrente de deriva litorânea, e erosão da margem à jusante da desembocadura. Este processo também causa a migração da desembocadura rumo a SW.

Durante periodos de passagem de frentes frias, o regime de ondas predominante é o de ondas provenientes do quadrante $\mathrm{SE}$, que induz uma corrente de deriva litorânea longitudinal à costa, no sentido NE. Neste contexto é sugerido o seguinte modelo de circulação das correntes de maré e dinâmica das margens na desembocadura lagunar do Ararapira (Fig.7.1 A):

1) a corrente de maré vazante flui, dentro do corpo lagunar, localizado atrás do esporão do Ararapira, com orientação paralela à linha de costa, na mesma direção da deriva, porém no sentido inverso; a inversão no sentido do fluxo, que ocorre na desembocadura, faz com que o padrão de circulação da corrente de vazante se assemelhe ao fluxo d'água num meandro;

2) os ventos provenientes do quadrante sul, que induzem ondas no sentido $\mathrm{NW}$, com intensidade superior a $6 \mathrm{~m} / \mathrm{s}$ e duração de no mínimo 20 horas (Camargo,R.; IAG-USP, comunicação 
pessoal), tem o papel de aprisionar água dentro do corpo lagunar, tendo então um quadro anòmalo de elevação do nível do mar; se os ventos cessarem num período coincidente com o de marés de sizigia, haverá um incremento no fluxo da corrente de maré vazante (Tessler \& Mahiques, 1993);

3) a corrente de maré vazante, ao se propagar pela desembocadura, atinge o delta de maré vazante e sofre uma inflexão para NE causada, em parte, pela forma do delta de vazante (delta de deriva litorânea segundo Reddering, 1983) (Fig.5.4) e, em parte, pela própria ação da deriva para $\mathrm{NE}$;

4) esta inflexão e a forma côncava da margem Ilha do Superagüi fazem com que a corrente de vazante assuma uma posição preferencial num canal principal, junto à esta margem (Reddering, 1983);

5) neste percurso a corrente de maré vazante exerce um grande poder erosivo na margem Ilha do Superagüi, retirando as areias da margem e depositando ao longo do delta de vazante;

6) a porção mais oceànica da margem Ilha do Superagüi apresenta acresção de areia, devido ao bloqueio dos sedimentos transportados pela deriva por causa do fluxo da corrente de vazante;

7) próximo à margem Ilha do Cardoso circulam as correntes de maré enchente como se pode verificar através das dunas subaquosas direcionadas para WNW (Foto 6.3.6.1-Prancha $\mathrm{C}$ e Fig. 5.4), encontradas nos terraços de baixa-mar;

8) a existència de bancos de areia semi-submersos, posicionados praticamente em continuidade com a margem, por sobre os quais circulam as correntes de enchente, propiciam uma zona de calmaria com propensão à acresção (Foto 6.4.1-Prancha C);

9) a circulação das correntes de maré enchente e vazante na porção localizada atrás do esporão recurvado da margem Ilha do Superagüi causam o crescimento de um esporão arenoso no sentido SW, que encerra uma enseada (Foto 6.3.1-Prancha C);

10)a circulação das correntes, durante os períodos de maré alta, provoca a erosão das margens desta enseada (Foto 6.3.3.1-Prancha $\mathrm{C}$ ), tornando cada vez mais estreita a faixa de planície costeira que separa a enseada, do mar; considerando-se que jả foi observada a existência de leques de sobrelavagem nesta faixa da planície (foto 6.3.1.1-Prancha C), é possível que haja, neste local, uma ruptura, o que ocasionaria uma aceleração brusca no processo erosão da margem e migração da desembocadura; 
11)após esta ruptura o material seria rapidamente erodido pela ação da corrente de vazante, caracterizando então, um processo de recuo da linha de costa determinado por eventos episódicos, além do recuo contínuo causado pela erosão da margem.

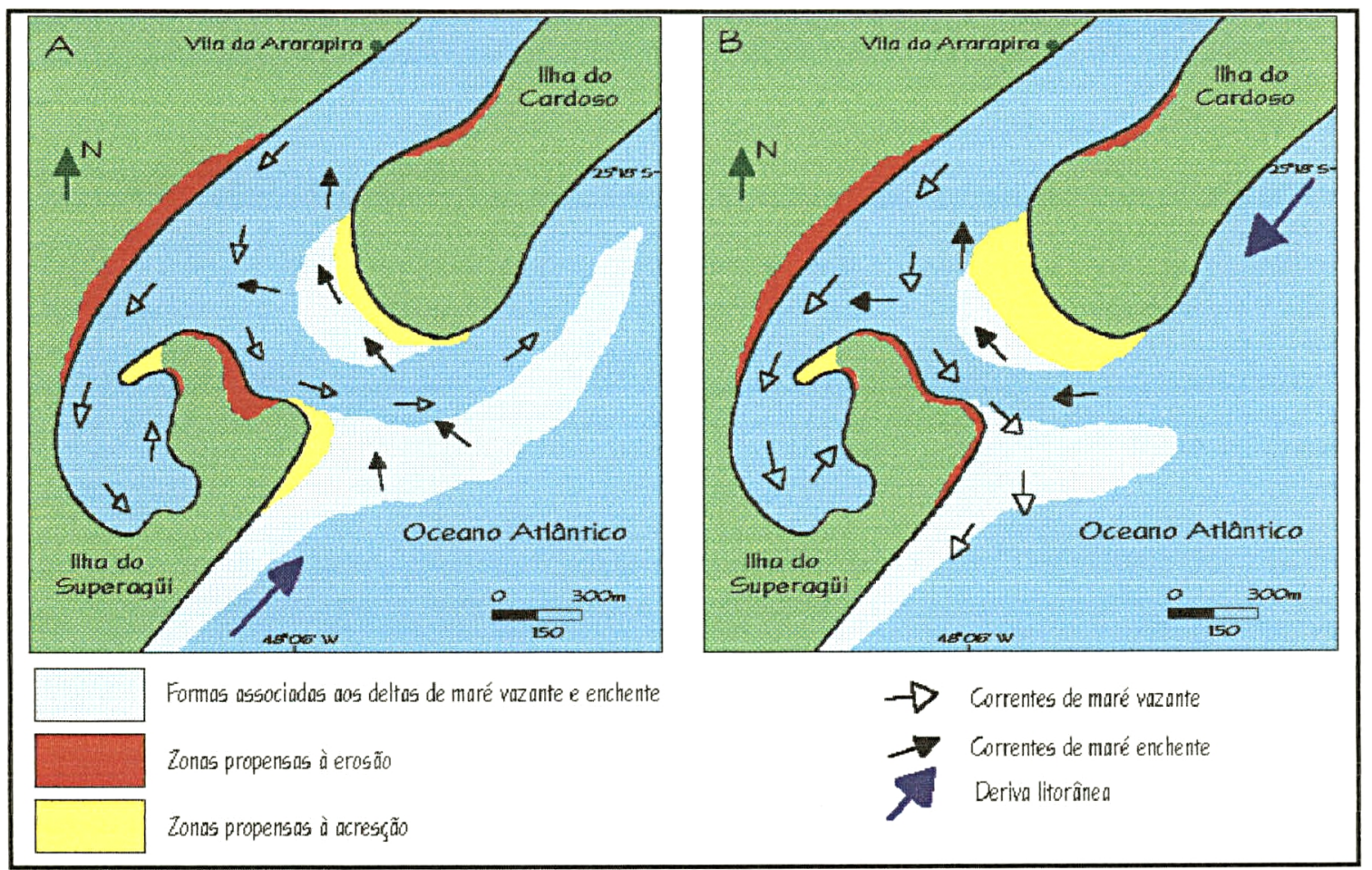

Figura 7.1. Modelos de circulação das correntes de maré e das areias durante a atuação da corrente de deriva litorânea longitudinal rumo a NE (figura $\mathrm{A}$ ) e rumo a SW (figura $\mathrm{B}$ ) na desembocadura lagunar do Ararapira.

Durante os períodos de inversão temporária da deriva, quando ela passa a ter sentido SW, ocorre uma intensificação do processo de acresção na margem Ilha do Cardoso. Dando sequência ao modelo de circulação das correntes de maré e das areias, durante a predominância da deriva rumo a NE, sugere-se aqui um segundo modelo que considera a deriva rumo a $\mathrm{SW}$ :

A) o crescimento da margem Ilha do Cardoso se dá pela acresção de areias transportadas pela corrente de deriva litorânea longitudinal, e bloqueadas pela corrente de maré vazante; este crescimento é acelerado pela coalescência da praia com os bancos de areia relacionados ao delta de maré enchente, localizados próximo à margem (Foto 6.4.1-Prancha $\mathrm{C}$ );

B) a maior parte das areias retidas na margem Ilha do Cardoso provém da erosão do delta de deriva litorânea; este torna-se mais curto, podendo inclusive, romper-se na porção mais 
proximal à margem Ilha do Superagüi, formando um segundo canal de circulação da corrente de maré vazante;

D) na margem Ilha do Superagüi ainda prevalece a erosão, porém não mais causada pelo efeito meandro, e sim pela falta de suprimento de sedimentos; ocorrendo com maior intensidade nas porções mais oceânicas da desembocadura.

Nos dois estreitamentos do esporão, que correspondem às margens côncavas de um corpo lagunar levemente meandrante, verificaram-se processos erosivos com recuo da falésia que margeia o corpo lagunar. No ponto 4 (Fig.4.2.1.1), localizado mais próximo à desembocadura do canal do Varadouro, o recuo foi menor do que no ponto 3 (Fig. 4.2.1.1), localizado mais a SW do primeiro. No ponto 3, que foi monitorado através do levantamento de très perfis paralelos, houve um estreitamento em torno de $20 \%$ da largura inicial num período de dois anos e oito meses. Considerou-se como largura do estreito a distância entre a falésia que margeia o corpo lagunar e a base do cordão dunar no lado oceânico, ou seja, entre as linhas de costa oceânica e lagunar, não se considerando a faixa de praia.

Tomando-se como base estes dados e considerando-se o trabalho sobre taxas de erosão de Godolphim (1983), poderia-se estimar a ruptura do estreito no ponto 3, num período aproximado de 15 anos. Conforme o modelo de FitzGerald (1988), a elongação do esporão do Ararapira causaria a gradativa ineficiência no fluxo da maré vazante no corpo lagunar localizado atrás do esporão; este fato, somado à ruptura do estreito, originaria uma nova desembocadura mais a NE da primeira, que facilitaria a vazão das águas, podendo causar o fechamento da atual desembocadura e o assoreamento da parte do corpo lagunar localizada a SW da nova desembocadura.

A distribuição das características granulométricas dos sedimentos nas praias estudadas vem fortalecer a suposição de inversão na direção da corrente de deriva litorânea, pois a distribuição não obedece a um padrão de tendència. A falta deste padrão poderia ser decorrente dos seguintes fatores: 1) aporte constante de sedimentos, devido à presença de constante descarga fluvial (Stapor \& May, 1983), no caso, os pequenos riachos que cortam a praia da Ilha do Superagüi, o Canal do Superagüi e a desembocadura lagunar do Ararapira; 2) proximidade da área fonte, sugerida pela predominància de formas angulosas nos minerais pesados e relativo estado de conservação dos minerais mais instáveis; 3) pouca influència da corrente de deriva litorânea sobre o transporte de sedimentos, ou por ela ser fraca ou porque a 
direção da costa, nesta região, não propicia uma ação efetiva das ondas e por conseguinte da corrente de deriva litorânea; 4) variação no ângulo de aproximação das ondas (Stapor \& May, 1983) o que acarretaria numa inversão periódica no sentido da deriva e 5) ação conjunta de dois ou mais fatores citados acima.

O terceiro item pode ser descartado, pois, considerando-se a pronunciada migração lateral, no sentido unidirecional, da desembocadura lagunar do Ararapira, pode-se concluir que há uma forte influência da corrente de deriva litorànea longitudinal. Sendo assim, admite-se que as características de distribuição dos sedimentos nestas praias estão condicionadas a um aporte constante de sedimentos, à proximidade da área fonte e à inversão periódica na direção da corrente de deriva litorânea, criando células de deriva. Todos estes fatores sem dúvida, não permitem identificar com clareza uma possivel tendência na distribuição dos sedimentos.

A praia da Ilha do Cardoso foi a única que apresentou um dos padrões conhecidos de distribuição das características granulométricas, segundo os modelos descritos por MacLaren \& Bowles (1985). Esta praia é a única que não apresenta a presença de riachos ao longo de sua extensão, portanto o aporte de sedimentos não seria tão constante quanto nas outras praias. $\mathrm{O}$ aumento no diâmetro médio dos grãos e assimetria mais positiva pode dever-se ao fato de existir na borda $\mathrm{NE}$ da praia, um costão rochoso, que bloqueia a passagem dos sedimentos mais grossos e dos minerais pesados, trasportados pela corrente de deriva litorânea longitudinal à costa, permitindo no entanto, a retirada de sedimentos mais finos. O que ocorre então é uma concentração maior de sedimentos grossos e minerais pesados nesta porção da praia do que em porções mais a SW. 


\section{8 - CONCLUSÕES}

As praias do litoral norte paranaense (praia da Ilha das Peças e Praia Deserta) e extremo sul paulista (Esporão do Ararapira - Ilha do Cardoso) apresentam características granulométricas muito semelhantes. São constituidas de areias finas, muito bem selecionadas e curvas de distribuição granulométrica extremamente leptocúrticas. A praia da Ilha das Peças apresenta areias aproximadamente simétricas, as da Praia Deserta apresentam assimetria negativa e as da praia do Esporão do Ararapira, assimetria positiva.

A distribuição das características granulométricas nas praias estudadas não apresentou nenhuma tendência evidente, tornando dificil a indicação do sentido da corrente de deriva litorânea a partir destes dados. A perturbação na distribuição dos sedimentos estaria relacionada aos seguintes fatores:

- aporte constante de sedimentos provenientes de uma área fonte não muito distante, através dos canais, riachos e desembocaduras existentes na região, que cortam as praias;

- inversões periódicas e temporárias no sentido da corrente de deriva litorânea longitudinal tornando-a bi-direcional;

- variações da hidrodinâmica ao longo da costa como, por exemplo, heterogeneidade na altura das ondas, decorrente de alterações batimétricas (Calliari, L.J.; Lab. Oc. Geol/Dep. Geoc.-FURG, comunicação pessoal) e;

- transporte de sedimentos na direção perpendicular à praia (cross-shore), que resulta em erosão e acresção desta (Masselink, 1992).

A única praia que apresentou um padrão de distribuição das características granulométricas, devido a ação da corrente de deriva litorânea longitudinal à costa, próximo ao "Modelo de McLaren" foi a praia da Ilha do Cardoso, por não apresentar, em toda a sua extensão, o aporte de sedimentos devido à presença de riachos. Esta praia apresentou, no sentido NE, melhoria na seleção, assimetria mais positiva e uma tendência a aumento do tamanho dos grãos (escala $\phi)$, porém ocorrem oscilações nos valores da granulometria, o que faz com que os valores de diâmetro médio não representem amostras sucessivamente mais grossas

As très praias apresentaram, no entanto, no sentido NE, uma melhora na seleção dos grãos e um incremento nos valores do indice ZTR. 
A distribuição dos processos erosivos e acrescionais, nas margens da desembocadura lagunar do Ararapira, estaria condicionada, basicamente, à inversão temporária no sentido da corrente de deriva litorânea longitudinal.

Quando o sentido da deriva é para NE, haveria o predomínio de processos erosivos na margem Ilha do Superagüi, sendo as areias, depositadas no delta de deriva litorânea. O processo de erosão da margem citada é semelhante ao que ocorre na margem côncava de um meandro. Isto, porque a deriva rumo a $\mathrm{NE}$ e o delta de deriva litorânea, condicionam uma inflexão para NE da corrente de maré vazante, tornando o fluxo semelhante ao de um rio meandrante.

Quando ocorre uma inversão no sentido da deriva, as areias que formam o delta de deriva litorânea seriam erodidas pela ação das ondas e depositadas na margem Ilha do Cardoso. Estas areias seriam depositadas nesta margem em decorrência do bloqueio da deriva pelo fluxo de vazante.

Estes dois processos, que ocorrem devido às inversões no sentido da deriva, acarretam na migração lateral da desembocadura lagunar do Ararapira no sentido SW, sentido este, inverso ao da corrente de deriva litorânea longitudinal predominante. A migração, por conseguinte, causa o crescimento lateral do esporão do Ararapira rumo a SW.

O esporão do Ararapira apresenta estreitamentos, nas localidades que correspondem às margens còncavas de suaves meandros do corpo lagunar, localizado atrás do esporão. O ponto mais estreito deste esporão apresenta, atualmente, uma largura de aproximadamente $36 \mathrm{~m}$; esta largura correspode à distância entre as duas linhas de costa, a lagunar e a oceânica. Num periodo de 32 meses houve um estreitamento de 10 metros, ou seja, de aproximadamente $20 \%$ da largura inicial, o que leva a uma estimativa de ruptura do esporão num prazo aproximado de 15 anos. Cabe ressaltar que esta previsão é passível de erro devido à relação entre a ocorrência de eventos episódicos, como passagens de frentes frias, e a aceleração dos eventos erosivos (Tessler \& Mahiques, 1993).

As consequências desta ruptura, juntamente com a elongação do corpo lagunar devido ao crescimento lateral do esporão do Ararapira, levariam à abertura de uma nova desembocadura mais a NE da atual e assoreamento de parte do corpo lagunar, localizado entre as duas desembocaduras, a antiga e a recente. 


\section{REFERÊNCIAS BIBLIOGRÁFICAS}

ANGUlo,R.J. -1992- Geologia da Planície Costeira do estado do Paraná. Tese de Doutoramento. São Paulo, DPE/IG-USP, 334p.

ANGULO,R.J. -1993- A Ocupação Urbana do Litoral Paranaense e as Variações da Linha de Costa. Bolm. Paran. Geoc. 41, p. 52-72.

ANGULO,R.J. -1993- Variações na Configuração da Linha de Costa no Paraná nas Últimas Quatro Décadas. Bolm. Paran. Geoc. 41, p.73-81.

ANGULO,R.J. -1995- Feições Deposicionais associadas às desembocaduras dos complexos estuarinos da costa paranaense. Anais do XI SIMPÓSIO DE SEDIMENTOLOGIA COSTEIRA. UFF, Niterói, RJ. p. 58-64.

ANGULO,R.J. -1996- Problemas na terminologia de ambientes e subambientes litorânaeos clásticos dominados por ondas. Bolm. Paran. Geoc. 44, (no prelo).

ANGULO,R.J. \& LESSA,G. -1996- The Brazilian sea level curves: a critical review with emphasis on the curves from Paranaguá and Cananeia regions. Anais do XXXIX CONGRESSO BRASILEIRO DE GEOLOGIA. Salvador, BA. Simpósios, v.5, p.285288.

ANGULO,R.J. \& SOARES,C.R. -1994- Beach profile variations between 1981 and 1993 in southern coast of Paraná State. Boletim Paranaense de Geocièncias, n.42, p.203-216.

AUBREY,D.G. \& SPEER,P.E. -1983-Clarification of mechanisms for updrift migration of natural unstructured tidal inlets. $I m$ : Sediment Transport in a Tidal Inlet, Technical Report, p.56-57.

BIGARELLA,J.J.; BECKER,R.D.; MATOS,D.I.de; WERNER,A. -1978- A Serra do Mar e a porção oriental do estado do Paraná: um problema de segurança ambiental e nacional Curitiba, Governo Paranaense/SEPL/ADEA. 248p.

BIGARELLA,J.J., FREIRE,S.S., SALAMUNI,R, VIANA,R. -1966- Contribuição ao estudo dos sedimentos praiais recentes, II - Praias de Matinhos e Caiobá. Bol.Univ.Fed.Paraná Geogr.Fís. nº6, 109p.

BITTENCOURT,A.C.S.P.; VILAS BOAS,G.S; FARIAS,F.F. -1992- Variações direcionais nos paràmetros granulométricos: um indicador apropriado para o sentido da deriva litorànea. Revista Brasileira de Geocièncias, v.22, nº 1, p. 100-106. 
BUSSAB,W.O. -1988- Análise de Regressão: uma introdução. 2ª̣ed. Coleção Métodos Quantitativos. São Paulo: Atual, 147p.

CALLIARI,L.J.; TOZZI,H.M.; KLEIN,A.H.da F. -1996- Erosão associada a marés meteorológicas na costa sul-riograndense (COMEMIR/OSNLR). Anais do XXXIX CONGRESSO BRASILEIRO DE GEOLOGIA. Salvador, BA. Simpósios, v.4, p.430434.

CARTER,R.W.G. -1988- Coastal Environments. An Introduction to the Physical, Ecological and Cultural Systems of Coastlines. London, Academic Press, 617p.

CARVER,R.E. -1971- Heavy-Mineral Separation. In: Procedures in Sedimentary Petrology, Carver,R.E. (Ed.), p.427-452.

CLIMANÁLISE - 1994/1995- Boletim de Monitoramento e Análise Climática. MCT/INPE, Cachoeira Paulista, SP. Centro de Previsão do Tempo e Estudos Climáticos - CPTEC. 1983, vol. $8 \mathrm{n}^{\mathrm{os}} 9-12 ; 1994$, vol. $9 \mathrm{n}^{\mathrm{os}} 1-12 ; 1995$, vol. $10 \mathrm{n}^{\mathrm{os}} 1-5$.

COIMBRA,M.C; GÓES,A.M; YAMAMOTO,J.K. -1991- Análise Granulométrica de Sedimentos - Apontamentos de Sedimentologia. São Paulo, DPE IG-USP. (não publicado)

DAVIS Jr.,R.A. -1983- Depositional systems: a genetic approach to sedimentary geology. Englewood Cliffs, New Jersey: Prentice-Hall, Inc, 669p.

DAVIS Jr.,R.A. -1994- Barrier Island System - a Geologic Overview. In: Geology of Holocene Barrier Island System, Davis Jr., R.A. (Ed.), 464p.

DEER,W.A.; HOWIE,R.A.; ZUSSMAN,J. -1966- Minerais constituintes das rochas - uma introdução. 556p.

FITZGERALD,D.M. -1988- Shoreline Erosional-Depositional Process Associated with Tidal Inlets. Lecture Notes on Coastal and Estuarine Studies. In: Hydrodynamics and Sediment Dynamics of Tidal Inlets, D.G. Aubrey, L.Weishar (Eds.), v.29, p. 186-225.

FOLK,R.L. \& WARD,W.C. 1957- Brazos river bar; a study in the significance of grain size parameters. Jour. Sedim. Petrol. 22(3):125-145.

FRIEDMAN,G.M. \& SANDERS,J.E. -1978- Principles of Sedimentology. New York, John Wiley \& Sons, New York, 729p.

GALEHOUSE,J.S. -1971- Point Counting. In: Procedures in Sedimentary Petrology, Carver,R.E. (Ed.), p.385-408. 
GAO,S. \& COLLINS,M. -1991- A critique of the "McLaren method" for defining sediment transport paths - discussion. Journ. Sed. Petr., vol.61, nº1, p. 143-146.

GIANNINI,P.C.F. -1987- Sedimentação quaternária na planície costeira de Peruíbe-Itanhaém (SP). São Paulo, Dissertação de Mestrado DPE/IG-USP. v.1, 116 p.

GIANNINI,P.C.F. -1993- Sistemas Deposicionais no Quaternário Costeiro entre Jaguaruna e Imbituba, SC. São Paulo, Tese de Doutoramento DPE IG-USP. vol.1, 278p.

GIANNINI,P.C.F. \& FERNANDES,H.C. -1984- Aplicação de análise de tendências por regressão múltipla a parâmetros sedimentológicos em duas áreas da costa sudoeste paulista. Anais do XXXIII CONGRESSO BRASILEIRO DE GEOLOGIA, Rio de Janeiro, p. 145-158.

GIESE,G.S. -1988- Cyclical Behavior of the Tidal Inlet at Nauset Beach, Chatham, Massachusetts. In : Hydrodynamics and Sediment Dynamics of Tidal Inlets, D.G. Aubrey, L.Weishar (Eds.), v. 29, p. 269-283

GODOLPHIM,M.F. -1983- Contribuição ao estudo da evolução da Barra do Rio Grande, Brasil. Pesquisas, Porto Alegre, $\mathrm{n}^{\mathrm{0}} 15, \mathrm{p} .22-43$.

HUBERT,J.F. -1962- A zircon-tourmaline-rutile maturity index and the interdependence of the composition of heavy mineral assemblages with the gross composition and texture of sandstones. Journ. Sedim. Petrology, 32(3):440-450.

HUBERT,J.F. -1971- Analysis of Heavy-Mineral Assemblages. In: Procedures in Sedimentary Petrology, Carver,R.E. (Ed.), p.453-478.

ISLA,F.I. -1984- Analisis de Variables que Rigen la Estabilidad y Obstruccion de Canales de Marea: el Caso de Mar Chiquita, Provincia de Buenos Aires. ACTAS DEL NOVENO CONGRESO GEOLOGICO ARGENTINO, S.C. de Bariloche. VI:218-242.

IPARDES - Instituto Paranaense de Desenvolvimento Econòmico e Social. Convênio IBAMA/MINTER - Instituto Brasileiro do Meio Ambiente e dos Recursos Naturais Renováveis - 1990 - Macrozoneamento da APA de Guaraqueçaba. Curitiba, v.1, 257p.

LANDIM,P.M.B. Análise Estatística de Dados Geológicos. Rio Claro, UNESP. Apostila de curso (inéd.), 104p.

LANKFORD,R.R. - 1977- Coastal Lagoons of Mexico. Their origin and classification. p. 182215. In: Wiley,M. (editor). Estuarine Processes. Academy Press Incorporation. New York. $2: 428 \mathrm{p}$. 
MASSELINK,G. -1992- Longshore Variation of Grain Size Distribution along the Coast of the Rhône Delta, Southern France: A Test of the "McLaren Model". Journal of Coastal Research, Florida, 8(2) p.286-291.

McLAREN,P - 1981- An Interpretation of Trends in Grain Size Measures. Journal of Sedimentary Petrology. v.51, no2, p.611-624.

McLAREN,P \& BOWLES,D. -1985- The effects of sediment transport on grain-size distributions. Journal of Sedimentary Petrology, v.55, no4, p.457-470.

MARONE,E. \& CAMARGO,R.de -1994- Marés Meteorológicas no Litoral do Estado do Paraná: o Evento de 18 de Agosto de 1993. Nerítica, Curitiba, PR. v.8(1-2), p.73-85.

MARONE,E.; PAULA PRATA Jr.,V.de; KLINGUENFUSS,M.S.; CAMARGO,R.de -1995Correntes de deriva no litoral paranaense: um caso de estudo. VI CONGRESO LATINOAMERICANO DE CIENCIAS DEL MAR. Item 475, p. 129.

MORTON,A,C, \& SMALE,D. -1990- The effects of transport and weathering on heavy minerals from the Cascade River, New Zealand. Sedimentary Geology, 68, p. 117-123.

MOSLOW,T.F. -1983- Depositional Models of Shelf and Shoreline Sandstones. Continuing Education, Course Note Series \#27, 101p.

MOSLOW,T.F. \& HERON,S.D. -1994- The Outer Banks of North Carolina. In: Geology of Holocene Barrier Island System, Davis Jr.,R.A. (Ed.), 464p.

NICHOLS,M. \& ALLEN,G. -1981- Sedimentary processes in coastal lagoons. Unesco Technical Papers in Marine Science - Coastal lagoon research, present and future, 33, p. 27-80.

OERTEL,G.F. -1985- The barrier island system. Marine Geology, 63 (1/4): 1-18

PETTIJOHN,F.J. - 1975- Sedimentary Rocks. 628p.

PORTOBRÁS - Empresa de Portos do Brasil S.A. -1988- Relatório de apresentação das medições meteorológicas observadas em Pontal do Sul. Paranaguá-PR, período set. 1982 a dez. 1986. Rio de Janeiro, Inst. Pesq. Hidr. (INPH), 189p.

READING,H.G. -1978- Sedimentary environments and facies. Blackwell Scientific Publications, 569p.

REDDERING,J.S.V. -1983- An inlet sequence produced by migration of a small microtidal inlet against longshore drift: the Keurbooms Inlet, South Africa. Sedimentology, 30,201218. 
REINECK,H.E. \& SINGH,I.B. -1975- Depositional Sedimentary Environments - with Reference to Terrigenous Clastics. Springer-Verlag, 349p.

SEPE,J. -1996- A Gestão da APA Cananéia-Iguape-Peruibe e os reflexos na atividade mineral de Iguape (SP). Anais do XXXIX CONGRESSO BRASILEIRO DE GEOLOGIA. Salvador, BA. Simpósios, v.4, p.57-60.

SOARES,C.R.; PARANHOS Filho,A.C.; SOUZA,M.C.de; $\quad$ BRANCO,J.C.; FABIANOVICZ,R.; PRAZERES Filho,H.J.dos; KOGUT,J.S. -1994- Variações da linha de costa no Balneário Pontal do Sul (PR) no período 1953-1993: um balanço sedimentar. Boletim Paranaense de Geocièncias, n.42, p.161-171.

SUGUIO,K. \& BIGARELLA,J.J. -1979- Ambientes de Sedimentação, sua interpretação e importância. Ambiente Fluvial. Ed.Univ.Fed.Paraná, ADEA - Curitiba, 183p.

SUGUIO,K. \& MARTIN,L. -1978- Formações quaternárias marinhas do litoral paulista e sul fluminense. INTERNATIONAL SYMPOSIUM ON COASTAL EVOLUTION IN THE QUATERNARY - Special Publication. 1 - The Brazilian National Working Group for the IGCP, Project 61. IG-USP, 550p.

SUGUIO,K. \& TESSLER,M.G. -1992- Depósitos quaternários da planície costeira de Cananéia-Iguape (SP). Roteiros das Excursões do $37^{\circ}$ CONGRESSO BRASILEIRO DE GEOLOGIA. São Paulo, SP. v.1, 31 p.

STAPOR Jr.,F.W. \& MAY,J.P. -1983- The cellular nature of littoral drift along the Northeast Florida Coast. Marine Geology, 51, p.217-237.

TAGGART,B.E. \& SCHWARTZ,M.L. -1987- Net Shore-Drift Direction Determination: A Systematic Approach. Journ. Shore Line Management 3(4) 285-309

TESSLER,M.G. -1988- Dinâmica Sedimentar Quaternária no Litoral Sul Paulista. Tese de Doutoramento. São Paulo, DPE/IG-USP.277p

TESSLER,M.G. \& FURTADO,V.V. -1983- Dinâmica de Sedimentação das Feições de Assoreamento da Região Lagunar Cananéia-Iguape, Estado de São Paulo. Bolm. Inst. Ocean., São Paulo, 32(2): 117-124.

TESSLER,M.G. \& MAHIQUES,M.M. -1993- Utilization of Coastal Geomorphic Features as indicators of Longshore Transport: Examples of the Southern Coastal Region of the State of São Paulo, Brasil. Journ. of Coastal Research 9(3) 823-830. 
VILAS BOAS,G.S. \& BITTENCOURT,A.C.S.P. -1992- Variação da energia e sua repercussão nas características composicionais e texturais em sedimentos praiais atuais: exemplo da costa leste da Baía de Todos os Santos, Bahia, Brasil. Revista Brasileira de Geociências, 22(3):311-320.

WENTWORTH,C.K. -1922- A scale of grade and class terms for clastic sediments. Journ. Geol., 30:377-392.

WU,F.T. -1981- Minerais Pesados de Sequencias Arenosas do Subgrupo Itararé no Sul do Estado de São Paulo. São Paulo, IG-USP, Dissert. de Mestrado, 78p. 
ANEXO 1. A) Tabela apresentando a porcentagem em volume e grau de arredondamento dos minerais pesados não magnéticos, correspondentes à fração entre 3 e 3,5 $\phi$, das praias das ilhas do Cardoso, do Superagüi e das Peças

\begin{tabular}{|c|c|c|c|c|c|c|c|c|c|c|c|c|c|}
\hline amostra & $\mathrm{CO2}$ & $\mathrm{COS}$ & C09 & C12 & $\mathrm{C} 16$ & S06 & S12 & S18 & S24 & S29 & P02 & P03 & P06 \\
\hline $\begin{array}{c}\text { minerais } \\
\text { opacos }(\%)\end{array}$ & 74 & 63 & 58 & 40 & 47 & 48 & 46 & 47 & 55 & 55 & 44 & 69 & 49 \\
\hline $\begin{array}{l}\text { forma dos } \\
\text { grãos }\end{array}$ & $\begin{array}{l}\text { ang. a } \\
\text { subang. }\end{array}$ & $\begin{array}{l}\text { ang. a } \\
\text { arred. }\end{array}$ & ang. & $\begin{array}{l}\text { ang. a } \\
\text { subang. }\end{array}$ & ang. & ang & $\begin{array}{l}\text { ang. a } \\
\text { arred. }\end{array}$ & $\begin{array}{l}\text { ang. a } \\
\text { arred. }\end{array}$ & $\begin{array}{l}\text { ang. } \mathbf{a} \\
\text { arred. }\end{array}$ & ang. & $\begin{array}{l}\text { ang. a } \\
\text { arred. }\end{array}$ & $\begin{array}{l}\text { ang. a } \\
\text { arred. }\end{array}$ & ang. \\
\hline \multicolumn{14}{|l|}{$\begin{array}{c}\text { minerais } \\
\text { transparentes } \\
(\%) \\
\end{array}$} \\
\hline zircão & arred. & ang. & ang. & ang & ang. & ang & & ang. & $\begin{array}{l}\text { ang. a } \\
\text { arred. }\end{array}$ & ang. & ang. & arred. & ang. \\
\hline \multirow[t]{2}{*}{ turmalina } & 54 & 47 & 48 & 54 & 48 & 51 & 50 & 35 & 47 & 44 & 60 & 30 & 49 \\
\hline & $\begin{array}{l}\text { arred. a } \\
\text { subarr. }\end{array}$ & $\begin{array}{l}\text { ang. a } \\
\text { arred. }\end{array}$ & arred. & $\begin{array}{l}\text { ang. a } \\
\text { arred. }\end{array}$ & $\begin{array}{l}\text { ang. a } \\
\text { arred. }\end{array}$ & $\begin{array}{l}\text { ang. a } \\
\text { arred. }\end{array}$ & arred. & $\begin{array}{l}\text { ang. a } \\
\text { arred. }\end{array}$ & arred. & ang. & $\begin{array}{l}\text { ang. a } \\
\text { arred. }\end{array}$ & $\begin{array}{l}\text { subang. } \\
\text { a arred. }\end{array}$ & $\begin{array}{l}\text { ang. a } \\
\text { arred. }\end{array}$ \\
\hline estaurolita & ang. & ang. & ang. & ang. & ang. & ang. & ang. & ang. & ang. & ang. & ang. & ang. & ang. \\
\hline monazita & - & - & - & - & - & - & - & - & - & - & - & 1 & - \\
\hline \multirow[t]{2}{*}{ granada } & 3 & traço & - & - & - & 2 & - & - & 1 & 2 & 4 & 2 & traço \\
\hline & - & - & - & - & - & - & - & - & - & ang. & $\begin{array}{l}\text { ang. } \mathrm{c} / \\
\text { picote/ }\end{array}$ & $\begin{array}{l}\text { ang. c/ } \\
\text { picote/ }\end{array}$ & - \\
\hline \multirow[t]{2}{*}{ pistachita } & 17 & 15 & 22 & 24 & 18 & 16 & 26 & 31 & 21 & 23 & 13 & 18 & 15 \\
\hline & ang. & ang. & ang. & ang. & ang. & ang. & ang. & ang. & ang. & ang. & ang. & - & ang. \\
\hline
\end{tabular}




\begin{tabular}{|c|c|c|c|c|c|c|c|c|c|c|c|c|c|}
\hline amostra & $\mathrm{CO} 2$ & $\mathrm{CO5}$ & $\mathrm{CO9}$ & $\mathrm{Cl2}$ & $\mathrm{C16}$ & S06 & S12 & S18 & S24 & S29 & P02 & P03 & P06 \\
\hline \multirow[t]{2}{*}{ cianita } & 9 & 7 & 6 & 4 & 6 & 2 & 3 & 6 & 4 & 2 & 2 & - & 2 \\
\hline & ang. & ang. & ang. & ang. & ang. & ang. & - & ang. & ang. & ang. & - & - & ang. \\
\hline \multirow[t]{2}{*}{ sillimanita } & 3 & 3 & - & 3 & 2 & 3 & 7 & 5 & 2 & 3 & 8 & 2 & 5 \\
\hline & ang. & ang. & - & ang. & ang. & ang. & ang. & ang. & ang. & ang. & - & ang. & ang. \\
\hline \multirow[t]{2}{*}{ barita } & - & traço & - & - & - & - & - & - & - & - & traço & - & traço \\
\hline & - & - & - & - & - & - & - & - & - & - & ang. & - & - \\
\hline \multirow[t]{2}{*}{ hornblenda } & 4 & 6 & 10 & 5 & 13 & 11 & 5 & 9 & 7 & 11 & 5 & traço & 9 \\
\hline & ang. & ang. & ang. & ang. & ang. & ang. & ang. & ang. & ang. & ang. & ang. & - & ang. \\
\hline diopsídio & - & - & - & traço & - & - & - & - & - & - & - & - & - \\
\hline \multirow[t]{2}{*}{ hiperstênio } & traço & 1 & 2 & 1 & 2 & 2 & 3 & 5 & 2 & 6 & - & 3 & 5 \\
\hline & $\begin{array}{l}\text { ang. } \mathrm{c} / \\
\text { dentea/ }\end{array}$ & - & ang. & ang. & $\begin{array}{l}\text { ang. } c / \\
\text { dentea/ }\end{array}$ & $\begin{array}{l}\text { ang. } \mathrm{c} / \\
\text { dentea/ }\end{array}$ & ang. & $\begin{array}{l}\text { ang. c/ } \\
\text { dentea/ }\end{array}$ & $\begin{array}{l}\text { ang. c/ } \\
\text { dentea/ }\end{array}$ & $\begin{array}{l}\text { ang. c/ } \\
\text { dentea/ }\end{array}$ & - & $\begin{array}{l}\text { ang. c/ } \\
\text { dentea/ }\end{array}$ & $\begin{array}{l}\text { ang. } c / \\
\text { dentea/ }\end{array}$ \\
\hline \multirow[t]{2}{*}{ andaluzita } & traço & 3 & - & 3 & 2 & 2 & 2 & 2 & 1 & 2 & 3 & traço & 3 \\
\hline & - & ang. & - & ang. & ang. & ang. & ang. & ang. & ang. & ang. & - & ang. & ang. \\
\hline scheelita & - & - & - & - & - & - & - & - & traço & traço & - & - & - \\
\hline clorita & - & - & - & - & - & - & - & - & - & traço & - & - & - \\
\hline alteritos & traço & - & traço & - & traço & traço & traço & - & - & - & traço & traço & traço \\
\hline $\begin{array}{c}\text { massa da } \\
\text { fração } \\
\text { pesada }(\%)\end{array}$ & 43,28 & 17,26 & 4,91 & 4,58 & 36,37 & 30,38 & 0,34 & 5,77 & 6,94 & 25,04 & 1,41 & 1,37 & 4,10 \\
\hline
\end{tabular}


Anexo 1. B) Mapa de localização das amostras (grifadas incluem minerais pesados).

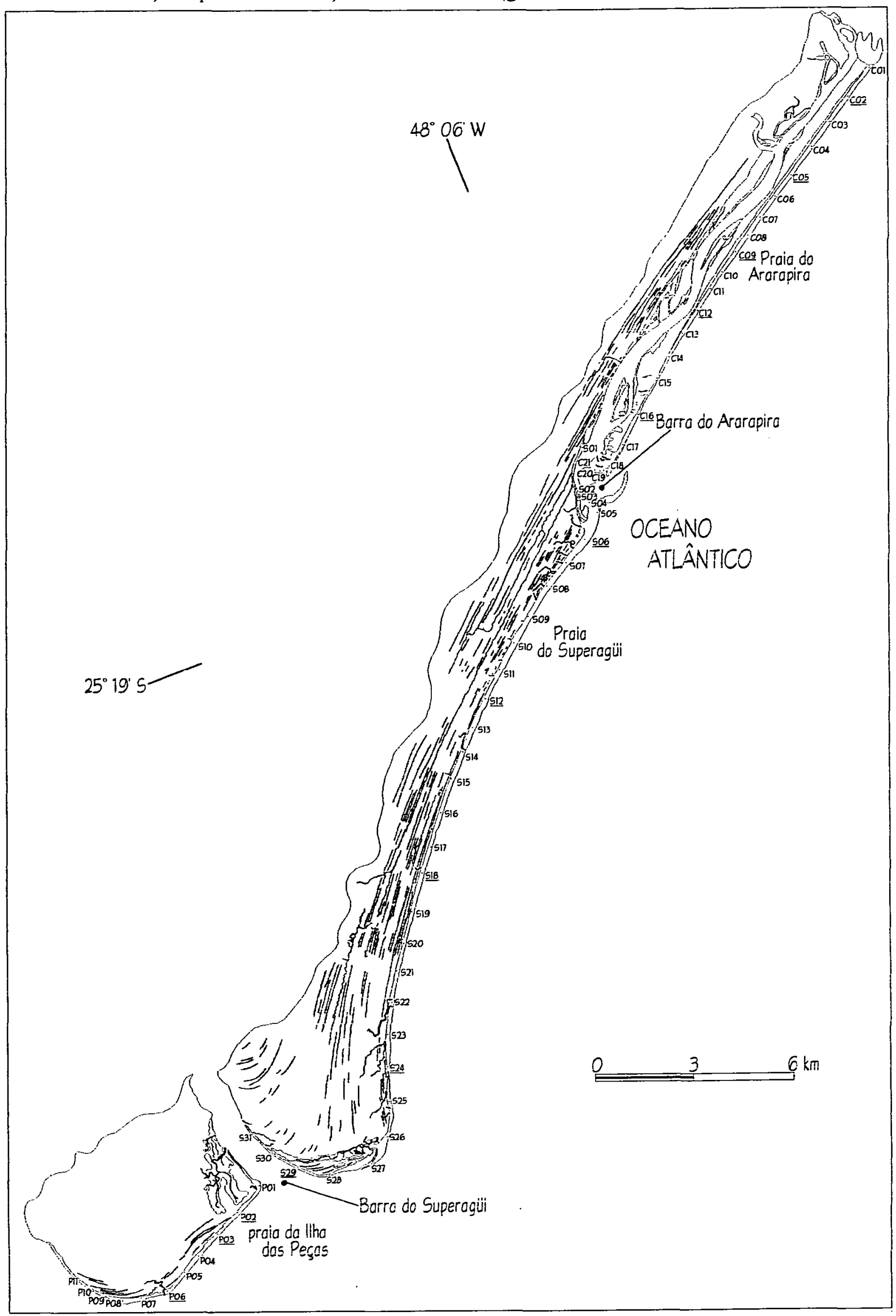


ANEXO 2. Tabelas dos Parâmetros Estatísticos da distribuição granulométrica segundo Técnica Analitica dos Momentos

Os códigos das amostras foram elaborados da seguinte maneira: a primeira letra se refere à identificação da praia, então $C$ para a praia na

Ilha do Cardoso, $\mathrm{S}$ para o Superagüi e $\mathrm{P}$ para a Ilha das Peças. O número se refere à localização ao longo da praia, todos iniciando na porção mais a NE, contadas em sua maioria, de um em um quilômetro. A letra seguinte se refere à localização na direção normal à praia, ou seja, B para a amostra coletada na linha de maré baixa relativa, A para a de maré alta relativa e D para a base do cordão dunar.

Praia do Ararapira (Ilha do Cardoso)

\begin{tabular}{|c|c|c|c|c|c|c|c|c|c|c|}
\hline $\begin{array}{l}\text { código da } \\
\text { amostra }\end{array}$ & $\begin{array}{l}\text { diâmetro } \\
\text { médio }(\phi)\end{array}$ & $\begin{array}{l}\text { desvióo } \\
\text { padrão }\end{array}$ & assimetría & curtose & $\begin{array}{l}\text { areia muito } \\
\text { grossa (g) }\end{array}$ & $\begin{array}{l}\text { arela grossa } \\
\text { (g) }\end{array}$ & \begin{tabular}{|c|} 
arefa media \\
$(\mathrm{g})$
\end{tabular} & areia lina (g) & $\begin{array}{c}\text { areia muito } \\
\text { fina }(\mathrm{g})\end{array}$ & $\begin{array}{l}\text { areia total } \\
(\mathrm{g})\end{array}$ \\
\hline C01B & 2.80 & 0.20 & 0.68 & 7.22 & 0.00 & 0.00 & 0.26 & 86.30 & 13.44 & 100.00 \\
\hline Co1A & 2.87 & 0.24 & 1.49 & 4.88 & 0.00 & 0.00 & 0.05 & 76.69 & 23.26 & 100.00 \\
\hline $\mathrm{CO} 2 \mathrm{~B}$ & 2.78 & 0.22 & -0.04 & 7.96 & 0.00 & 0.00 & 0.64 & 87.16 & 12.20 & 100.00 \\
\hline $\mathrm{CO} 2 \mathrm{~A}$ & 2.86 & 0.22 & 1.36 & 4.90 & 0.00 & 0.00 & 0.09 & 78.88 & 21.03 & 100.00 \\
\hline $\mathrm{C}(12 \mathrm{D}$ & 2.86 & 0.23 & 1.58 & 5.70 & 0.00 & 0.00 & 0.06 & 79.52 & 20.43 & 100.00 \\
\hline $\mathrm{C} 03 \mathrm{~B}$ & 2.75 & 0.22 & -0.40 & 8.09 & 0.00 & 0.02 & 0.40 & 90.41 & 9.17 & 100.00 \\
\hline $\mathrm{CO3A}$ & 2.86 & 0.23 & 0.98 & 4.43 & 0.00 & 0.00 & 0.12 & 77.61 & 22.27 & 100.00 \\
\hline CO3D & 2.89 & 0.25 & 0.98 & 3.59 & 0.00 & 0.00 & 0.06 & 72.53 & 27.41 & 100.00 \\
\hline $\mathrm{C}(0+\mathrm{B}$ & 2.78 & 0.25 & -0.33 & 6.48 & 0.00 & 0.00 & 0.94 & 84.42 & 14.63 & 100.00 \\
\hline $\mathrm{CO}+\mathrm{A}$ & 2.85 & 0.24 & 1.14 & 6.00 & 0.00 & 0.00 & 0.18 & 78.79 & 21.03 & 100.00 \\
\hline$C 0+D$ & 2.85 & 0.23 & 1.35 & 5.63 & 0.00 & 0.00 & 0.07 & 80.50 & 19.42 & 100.00 \\
\hline C05B & 2.80 & 0.24 & 0.27 & 6.20 & 0.00 & 0.00 & 0.45 & 84.28 & 15.27 & 100.00 \\
\hline C05A & 2.89 & 0.27 & 1.36 & 4.56 & 0.00 & 0.00 & 0.03 & 73.83 & 26.14 & 100.00 \\
\hline CO5D & 2.89 & 0.25 & 1.05 & 3.90 & 0.00 & 0.00 & 0.03 & 73.09 & 26.88 & 100.00 \\
\hline C06B & 2.81 & 0.22 & 0.72 & 6.78 & 0.00 & 0.00 & 0.23 & 85.38 & 14.39 & 100.00 \\
\hline C06A & 2.86 & 0.26 & 1.02 & 5.15 & 0.00 & 0.00 & 0.15 & 76.88 & 22.97 & 100.00 \\
\hline C06D & 2.89 & 0.25 & 0.89 & 3.47 & 0.00 & 0.00 & 0.05 & 71.39 & 28.56 & 100.00 \\
\hline C(17B & 2.85 & 0.24 & 0.70 & 4.63 & 0.00 & 0.00 & 0.15 & 78.24 & 21.61 & 100.00 \\
\hline C07A & 2.81 & 0.23 & 0.32 & 6.61 & 0.00 & 0.00 & 0.52 & 83.55 & 15.93 & 100.00 \\
\hline CO7D & 2.83 & 0.28 & 1.05 & 6.09 & 0.00 & 0.00 & 0.31 & 81.10 & 18.59 & 100.00 \\
\hline C08B & 2.83 & 0.25 & 0.23 & 5.30 & 0.00 & 0.01 & 0.36 & 78.51 & 21.12 & 100.00 \\
\hline C08A & 2.83 & 0.25 & 0.20 & 5.61 & 0.00 & 0.01 & 0.44 & 79.18 & 20.37 & 100.00 \\
\hline C08D & 2.92 & 0.25 & 0.33 & 6.16 & 0.01 & 0.01 & 0.04 & 66.59 & 33.35 & 100.00 \\
\hline C09B & 2.82 & 0.26 & 0.04 & 5.17 & 0.00 & 0.00 & 0.60 & 79.89 & 19.51 & 100.00 \\
\hline C(19A & 2.90 & 0.26 & 0.74 & 3.14 & 0.00 & 0.00 & 0.06 & 69.07 & 30.87 & 100.00 \\
\hline
\end{tabular}




\begin{tabular}{|c|c|c|c|c|c|c|c|c|c|c|}
\hline $\begin{array}{c}\text { codigo da } \\
\text { amostra }\end{array}$ & $\begin{array}{l}\text { diametro } \\
\text { médio }(\phi)\end{array}$ & $\begin{array}{l}\text { desvio } \\
\text { padrã̃o }\end{array}$ & assimetria & curtose & $\begin{array}{c}\text { arela milito } \\
\text { grossa }(g)\end{array}$ & $\begin{array}{c}\text { areia grossa } \\
(\mathrm{g})\end{array}$ & $\begin{array}{c}\text { areia media } \\
(\mathrm{g})\end{array}$ & areia Tina ( $\mathrm{g}$ & $\begin{array}{c}\text { arela mulito } \\
\text { lina }(\mathrm{g})\end{array}$ & $\begin{array}{c}\text { arela total } \\
\text { (g) }\end{array}$ \\
\hline Co9D & 3.00 & 0.27 & -0.17 & 5.01 & 0.00 & 0.04 & 0.04 & 50.39 & 49.53 & 100.00 \\
\hline C10B & 2.78 & 0.32 & -0.57 & 4.71 & 0.00 & 0.00 & 2.43 & 77.09 & 20.47 & 100.00 \\
\hline C10A & 2.85 & 0.26 & 0.43 & 4.56 & 0.00 & 0.00 & 0.29 & 75.96 & 23.75 & 100.00 \\
\hline C10D & 2.96 & 0.26 & 0.37 & 2.37 & 0.00 & 0.00 & 0.05 & 59.03 & 40.92 & 100.00 \\
\hline C11B & 2.82 & 0.23 & 0.45 & 6.08 & 0.00 & 0.00 & 0.39 & 81.89 & 17.72 & 100.00 \\
\hline C11A & 2.80 & 0.23 & 0.12 & 7.44 & 0.00 & 0.00 & 0.64 & 84.95 & 14.41 & 100.00 \\
\hline C11D & 2.88 & 0.23 & 1.30 & 4.05 & 0.00 & 0.00 & 0.03 & 75.37 & 24.60 & 100.00 \\
\hline C12B & 2.81 & 0.27 & -0.23 & 5.45 & 0.00 & 0.00 & 1.04 & 79.61 & 19.35 & 100.00 \\
\hline $\mathrm{C} 12 \mathrm{~A}$ & 2.84 & 0.29 & -0.10 & 4.61 & 0.00 & 0.00 & 0.88 & 74.28 & 24.84 & 100.00 \\
\hline C12D & 2.90 & 0.27 & 0.25 & 3.51 & 0.00 & 0.00 & 0.27 & 67.00 & 32.73 & 100.00 \\
\hline C13B & 2.83 & 0.28 & -0.16 & 5.23 & 0.00 & 0.00 & 1.01 & 75.99 & 23.00 & 100.00 \\
\hline C13A & 2.88 & 0.26 & 0.28 & 3.79 & 0.00 & 0.00 & 0.33 & 70.45 & 29.22 & 100.00 \\
\hline C13D & 3.00 & 0.26 & 0.17 & 1.63 & 0.00 & 0.00 & 0.02 & 51.52 & 48.46 & 100.00 \\
\hline $\mathrm{C} 1+\mathrm{B}$ & 2.84 & 0.25 & 0.07 & 5.71 & 0.00 & 0.00 & 0.69 & 77.38 & 21.93 & 100.00 \\
\hline $\mathrm{C} 14 \mathrm{~A}$ & 2.86 & 0.24 & 0.65 & 4.30 & 0.00 & 0.00 & 0.22 & 75.68 & 24.10 & 100.00 \\
\hline $\mathrm{C} 1+\mathrm{D}$ & 2.87 & 0.24 & 1.00 & 4.43 & 0.00 & 0.00 & 0.11 & 75.62 & 24.27 & 100.00 \\
\hline C15A & 2.84 & 0.24 & 0.23 & 5.44 & 0.00 & 0.00 & 0.51 & 78.18 & 21.31 & 100.00 \\
\hline C15D & 2.83 & 0.21 & 1.49 & 8.00 & 0.00 & 0.01 & 0.09 & 83.12 & 16.78 & 100.00 \\
\hline $\mathrm{C16B}$ & 2.83 & 0.24 & 0.32 & 5.56 & 0.00 & 0.00 & 0.41 & 79.70 & 19.89 & 100.00 \\
\hline $\mathrm{C16A}$ & 2.89 & 0.25 & 1.00 & 3.59 & 0.00 & 0.00 & 0.06 & 71.65 & 28.29 & 100.00 \\
\hline C16D & 2.89 & 0.24 & 0.85 & 3.44 & 0.00 & 0.00 & 0.11 & 72.19 & 27.70 & 100.00 \\
\hline C17B & 2.80 & 0.25 & -0.21 & 6.55 & 0.00 & 0.00 & 1.00 & 82.19 & 16.81 & 100.00 \\
\hline C17A & 2.89 & 0.24 & 0.90 & 3.27 & 0.00 & 0.00 & 0.06 & 71.47 & 28.47 & 100.00 \\
\hline C17D & 2.99 & 0.27 & 0.29 & 1.93 & 0.00 & 0.00 & 0.03 & 52.84 & +7.13 & 100.00 \\
\hline C18B & 2.80 & 0.27 & -0.65 & 7.74 & 0.00 & 0.02 & 1.56 & 80.42 & .18 .00 & 100.00 \\
\hline C18A & 2.87 & 0.27 & 0.02 & 5.07 & 0.00 & 0.00 & 0.73 & 72.65 & 26.62 & 100.00 \\
\hline C18D & 2.86 & 0.23 & 0.77 & 5.42 & 0.00 & 0.00 & 0.27 & 77.12 & 22.61 & 100.00 \\
\hline C19B & 2.81 & 0.24 & 0.16 & 5.69 & 0.00 & 0.00 & 0.50 & 81.77 & 17.73 & 100.00 \\
\hline C19A & 2.86 & 0.25 & 1.41 & 5.51 & 0.00 & 0.00 & 0.06 & 77.99 & 21.95 & 100.00 \\
\hline C20B & 2.85 & 0.22 & 1.59 & 5.68 & 0.00 & 0.00 & 0.03 & 80.92 & 19.05 & 100.00 \\
\hline C20A & 2.89 & 0.25 & 1.35 & 4.30 & 0.00 & 0.00 & 0.02 & 73.81 & 26.17 & 100.00 \\
\hline C21B & 2.80 & 0.21 & 0.44 & 7.90 & 0.00 & 0.01 & 0.27 & 85.47 & 14.25 & 100.00 \\
\hline $\mathrm{C} 21 \mathrm{~A}$ & 2.98 & 0.27 & 0.52 & 2.12 & 0.00 & 0.00 & 0.01 & 55.84 & 44.15 & 100.00 \\
\hline
\end{tabular}


Praia Deserta (Ilha do Superagüi)

\begin{tabular}{|c|c|c|c|c|c|c|c|c|c|c|}
\hline $\begin{array}{l}\text { cidigo da } \\
\text { amostra }\end{array}$ & $\begin{array}{l}\text { diâmetro } \\
\text { médio }(\phi)\end{array}$ & $\begin{array}{l}\text { desvio } \\
\text { padrão }\end{array}$ & assimetria & curtose & $\begin{array}{l}\text { arcia muito } \\
\text { grossa }(\mathrm{g})\end{array}$ & \begin{tabular}{|c|}
$\begin{array}{c}\text { arcia grossa } \\
(\mathrm{g})\end{array}$ \\
\end{tabular} & $\begin{array}{c}\text { areia média } \\
\text { (g) }\end{array}$ & arcia fina $(\mathrm{g})$ & $\begin{array}{c}\text { areia muito } \\
\text { lina }(\mathrm{g})\end{array}$ & $\begin{array}{l}\text { areia tolal } \\
\text { (g) }\end{array}$ \\
\hline S01B & 2.38 & 0.49 & -0.11 & 2.41 & 0.00 & 0.14 & 24.88 & 66.84 & 8.14 & 100.00 \\
\hline S01A & 2.82 & 0.32 & 0.09 & 4.75 & 0.00 & 0.01 & 0.90 & 76.17 & 22.92 & 100.00 \\
\hline $\begin{array}{c}\mathrm{S}(12 \\
\text { fundo de } \\
\text { canal } \\
\end{array}$ & 3.08 & 0.30 & -1.94 & 18.88 & 0.06 & 0.04 & 0.32 & 33.58 & 66.00 & 100.00 \\
\hline $\begin{array}{c}\text { S03 } \\
\text { fundo de } \\
\text { canal }\end{array}$ & 2.90 & 0.25 & 0.61 & 3.80 & 0.00 & 0.01 & 0.11 & 69.64 & 30.24 & 100.00 \\
\hline S04B & 2.83 & 0.24 & 0.67 & 6.86 & 0.00 & 0.01 & 0.30 & 81.67 & 18.02 & 100.00 \\
\hline$S 04 A$ & 2.85 & 0.24 & 1.28 & 6.73 & 0.00 & 0.01 & 0.12 & 80.43 & 19.44 & 100.00 \\
\hline S05B & 2.89 & 0.26 & 0.52 & 3.55 & 0.00 & 0.00 & 0.18 & 69.90 & 29.92 & 100.00 \\
\hline S05A & 2.92 & 0.25 & 0.72 & 2.86 & 0.00 & 0.00 & 0.06 & 66.77 & 33.17 & 100.00 \\
\hline S05D & 2.92 & 0.26 & 1.04 & 3.41 & 0.00 & 0.00 & 0.03 & 67.76 & 32.21 & 100.00 \\
\hline S106B & 2.81 & 0.24 & 0.07 & 6.41 & 0.00 & 0.01 & 0.55 & 82.35 & 17.09 & 100.00 \\
\hline S1)6A & 2.80 & 0.22 & 0.41 & 6.82 & 0.00 & 0.00 & 0.37 & 84.89 & 14.74 & 100.00 \\
\hline S060 & 2.89 & 0.24 & 1.00 & 4.00 & 0.00 & 0.01 & 0.04 & 72.40 & 27.55 & 100.00 \\
\hline S07B & 2.80 & 0.25 & -0.08 & 6.33 & 0.00 & 0.00 & 0.77 & 82.93 & 16.30 & 100.00 \\
\hline $\mathrm{S} 07 \mathrm{~A}$ & 2.81 & 0.23 & 0.30 & 7.06 & 0.00 & 0.01 & 0.40 & 84.28 & 15.31 & 100.00 \\
\hline S07D & 2.85 & 0.23 & 1.57 & 6.48 & 0.00 & 0.01 & 0.04 & 80.34 & 19.61 & 100.00 \\
\hline S1)8B & 2.89 & 0.34 & -0.64 & 3.61 & 0.00 & 0,00 & 1,48 & 60.25 & 38.27 & 100.00 \\
\hline S08A & 3.04 & 0.30 & -1.09 & 3.83 & 0.00 & 0.00 & 0.32 & 36.78 & 62.90 & 100.00 \\
\hline S08D & 3.16 & 0.22 & -2.12 & 8.04 & 0.00 & 0.00 & 0.10 & 17.00 & 82.90 & 100.00 \\
\hline S09B & 2.84 & 0.38 & -0.69 & 3.35 & 0.00 & 0.00 & 2.92 & 61.41 & 35.67 & 100.00 \\
\hline S09A & 2.97 & 0.31 & -0.72 & 3.20 & 0.00 & 0.00 & 0.45 & 48.71 & 50.84 & 100.00 \\
\hline S109D & 2.89 & 0.29 & 0.26 & 3.86 & 0.00 & 0.00 & 0.31 & 68.15 & 31.54 & 100.00 \\
\hline S10B & 2.75 & 0.32 & -0.63 & 4.64 & 0.00 & 0.00 & 2.72 & 79.52 & 17.76 & 100.00 \\
\hline S10A & 2.89 & 0.26 & 0.34 & 3.22 & 0.00 & 0.00 & 0.15 & 70.07 & 29.78 & 100.00 \\
\hline S10D & 2.93 & 0.26 & 0.16 & 2.90 & 0.00 & 0.00 & 0.20 & 63.11 & 36.69 & 100.00 \\
\hline S11B & 2.83 & 0.31 & -0.37 & 3.99 & 0.00 & 0.00 & 1.24 & 71.73 & 27.03 & 100.00 \\
\hline S11A & 2.89 & 0.28 & 0.08 & 3.36 & 0.00 & 0.00 & 0.30 & 67.32 & 32.38 & 100.00 \\
\hline S11D & 2.97 & 0.28 & -0.32 & 3.68 & 0.00 & 0.02 & 0.13 & 53.61 & 46.24 & 100.00 \\
\hline S12B & 2.67 & 0.41 & -0.74 & 3.66 & 0.00 & 0.06 & 8.40 & 73.58 & 17.96 & 100.00 \\
\hline
\end{tabular}




\begin{tabular}{|c|c|c|c|c|c|c|c|c|c|c|}
\hline $\begin{array}{l}\text { código da } \\
\text { amostra }\end{array}$ & $\begin{array}{l}\text { diametro } \\
\text { medio }(\phi)\end{array}$ & $\begin{array}{l}\text { desvio } \\
\text { padrũo }\end{array}$ & assimetria & curtose & $\begin{array}{c}\text { arela mulito } \\
\text { grossa }(\mathrm{g})\end{array}$ & $\begin{array}{c}\text { areia grossa } \\
(\mathrm{g})\end{array}$ & $\begin{array}{c}\text { areia media } \\
\text { (g) }\end{array}$ & arcia tina (g) & $\begin{array}{c}\text { areia muito } \\
\operatorname{lina}(g)\end{array}$ & $\begin{array}{l}\text { areat total } \\
\text { (B) }\end{array}$ \\
\hline S12A & 2.91 & 0.26 & 0.29 & 2.92 & 0.00 & 0.00 & 0.15 & 65.73 & 34.12 & 100.00 \\
\hline S12D & 2.96 & 0.27 & -0.12 & 2.33 & 0.00 & 0.00 & 0.12 & 55.27 & 44.61 & 100.00 \\
\hline S13B & 2.72 & 0.38 & -0.78 & 3.99 & 0.00 & 0.00 & 5.89 & 73.90 & 20.21 & 100.00 \\
\hline S13A & 2.94 & 0.27 & 0.31 & 2.61 & 0.00 & 0.00 & 0.07 & 60.65 & 39.28 & 100.00 \\
\hline S13D & 3.05 & 0.26 & -0.27 & 2.08 & 0.00 & 0.00 & 0.03 & $40 . \overline{78}$ & 59.19 & 100.00 \\
\hline S14B & 2.73 & 0.36 & -0.75 & 4.16 & 0.00 & 0.00 & 4.97 & 75.54 & 19.49 & 100.00 \\
\hline$S 14 A$ & 2.91 & 0.28 & 0.10 & 3.17 & 0.00 & 0.00 & 0.27 & 64.38 & 35.35 & 100.00 \\
\hline S14D & 2.99 & 0.27 & 0.16 & 1.95 & 0.00 & 0.00 & 0.03 & 52.99 & 46.98 & 100.00 \\
\hline S15B & 2.80 & 0.28 & -0.33 & 5.00 & 0.00 & 0.00 & 1.13 & 79.36 & 19.51 & 100.00 \\
\hline S15A & 2.95 & 0.27 & 0.03 & 2.49 & 0.00 & 0.00 & 0.14 & 58.95 & 40.91 & 100.00 \\
\hline S15D & 2.85 & 0.34 & -0.60 & 3.98 & 0.00 & 0.00 & 2.06 & 65.28 & 32.66 & 100.00 \\
\hline S16B & 2.71 & 0.39 & -0.71 & 4.12 & 0.00 & 0.02 & 6.12 & 75.58 & 18.28 & 100.00 \\
\hline S16A & 2.93 & 0.29 & 0.40 & 3.30 & 0.00 & 0.00 & 0.18 & 63.19 & 36.63 & 100.00 \\
\hline S16D & 3.00 & 0.26 & -0.04 & 1.71 & 0.00 & 0.00 & 0.00 & 49.73 & 50.27 & 100.00 \\
\hline S17B & 2.80 & 0.34 & -0.68 & 4.38 & 0.00 & 0.00 & 2.76 & 72.50 & 24.74 & 100.00 \\
\hline $\mathrm{S} 17 \mathrm{~A}$ & 2.95 & 0.27 & -0.04 & 2.48 & 0.00 & 0.00 & 0.17 & 58.58 & 41.25 & 100.00 \\
\hline S17D & 2.99 & 0.26 & 0.08 & 1.62 & 0.00 & 0.00 & 0.00 & 51.25 & 48.75 & 100.00 \\
\hline S18B & 2.82 & 0.31 & -0.53 & 4.58 & 0.00 & 0.00 & 1.46 & 72.84 & 25.70 & 100.00 \\
\hline S18A & 2.93 & 0.26 & 0.24 & 2.34 & 0.00 & 0.00 & 0.07 & 61.82 & 38.11 & 100.00 \\
\hline S18D & 2.95 & 0.31 & -1.41 & 9.59 & 0.00 & 0.00 & 1.07 & 55.78 & 43.15 & 100.00 \\
\hline S19B & 2.84 & 0.30 & -0.38 & 4.44 & 0.00 & 0.00 & 1.09 & 71.87 & 27.04 & 100.00 \\
\hline S19A & 2.89 & 0.27 & 0.01 & 3.38 & 0.00 & 0.00 & 0.35 & 68.08 & 31.57 & 100.00 \\
\hline S19D & 3.03 & 0.26 & -0.15 & 1.63 & 0.00 & 0.00 & 0.00 & 44.87 & 55.13 & 100.00 \\
\hline S20B & 2.78 & 0.32 & -0.52 & 4.39 & 0.00 & 0.00 & 2.17 & 76.89 & 20.94 & 100.00 \\
\hline S20A & 2.90 & 0.27 & 0.28 & 2.94 & 0.00 & 0.00 & 0.12 & 67.00 & 32.88 & 100.00 \\
\hline S20D & 2.96 & 0.27 & 0.25 & 2.27 & 0.00 & 0.00 & 0.06 & 58.54 & 41.40 & 100.00 \\
\hline S21B & 2.76 & 0.34 & -0.85 & 5.08 & 0.00 & 0.03 & 3.64 & 76.53 & 19.80 & 100.00 \\
\hline S21A & 2.84 & 0.28 & 0.05 & 4.26 & 0.00 & 0.00 & 0.54 & 74.64 & 24.82 & 100.00 \\
\hline S21D & 2.96 & 0.28 & -0.75 & 10.79 & 0.03 & 0.06 & 0.08 & 56.22 & 43.61 & 100.00 \\
\hline S22B & 2.40 & 0.60 & -0.86 & 3.38 & 0.03 & 2.45 & 22.69 & 64.66 & 10.16 & 100.00 \\
\hline S22A & 2.80 & 0.27 & -0.19 & 4.59 & 0.00 & 0.00 & 0.77 & 79.77 & 19.46 & 100.00 \\
\hline S22D & 2.97 & 0.26 & 0.19 & 1.89 & 0.00 & 0.00 & 0.03 & 55.76 & 44.21 & 100.00 \\
\hline S23B & 2.68 & 0.39 & -1.02 & 4.87 & 0.00 & 0.09 & 7.22 & 77.76 & 14.93 & 100.00 \\
\hline
\end{tabular}




\begin{tabular}{|c|c|c|c|c|c|c|c|c|c|c|}
\hline $\begin{array}{c}\text { coldigo dai } \\
\text { amostra }\end{array}$ & $\begin{array}{l}\text { Thametro } \\
\text { médios }(\phi)\end{array}$ & $\begin{array}{l}\text { dessió } \\
\text { padirino }\end{array}$ & assimetria & curtose & $\begin{array}{c}\text { aresa mulito } \\
\text { grossa }(g)\end{array}$ & \begin{tabular}{|c|} 
areia grossa \\
$(\mathrm{g})$
\end{tabular} & $\begin{array}{c}\text { arela media } \\
(\mathrm{g})\end{array}$ & areia fina (g) & $\begin{array}{c}\text { arelia milito } \\
\text { fina }(g)\end{array}$ & $\begin{array}{c}\text { arela total } \\
(g)\end{array}$ \\
\hline S23A & 2.90 & 0.27 & 0.12 & 3.03 & 0.00 & 0.00 & 0.18 & 66.92 & 32.90 & 100.00 \\
\hline S23D & 3.02 & 0.27 & -0.06 & 1.92 & 0.00 & 0.00 & 0.03 & 47.25 & 52.72 & 100.00 \\
\hline S24B & 2.85 & 0.31 & -0.41 & 4.70 & 0.00 & 0.00 & 1.42 & 70.37 & 28.21 & 100.00 \\
\hline$S 24 A$ & 2.97 & 0.27 & 0.34 & 2.33 & 0.00 & 0.00 & 0.06 & 56.49 & 43.45 & 100.00 \\
\hline S24D & 2.98 & 0.27 & 0.16 & 2.29 & 0.00 & 0.00 & 0.08 & 54.86 & 45.06 & 100.00 \\
\hline S25B & 2.78 & 0.29 & -0.34 & 5.13 & 0.00 & 0.00 & 1.45 & 80.71 & 17.84 & 100.00 \\
\hline S25A & 2.89 & 0.27 & 0.64 & 3.68 & 0.00 & 0.00 & 0.13 & 70.47 & 29.40 & 100.00 \\
\hline S25D & 3.00 & 0.27 & 0.11 & 2.38 & 0.00 & 0.00 & 0.06 & 50.41 & 49.53 & 100.00 \\
\hline S26B & 2.78 & 0.31 & -0.58 & 4.83 & 0.00 & 0.00 & 2.29 & 77.79 & 19.92 & 100.00 \\
\hline S26A & 2.75 & 0.27 & -0.59 & 6.08 & 0.00 & 0.00 & 1.51 & 86.63 & 11.86 & 100.00 \\
\hline S26D & 2.96 & 0.28 & -0.23 & 7.83 & 0.00 & 0.08 & 0.15 & 58.92 & 40.85 & 100.00 \\
\hline S27B & 2.73 & 0.32 & -0.83 & 5.17 & 0.00 & 0.00 & 3.77 & 81.89 & 14.35 & 100.00 \\
\hline S27A & 2.91 & 0.25 & 0.40 & 2.54 & 0.00 & 0.00 & 0.13 & 67.47 & 32.40 & 100.00 \\
\hline S27D & 2.95 & 0.26 & 0.46 & 2.55 & 0.00 & 0.00 & 0.10 & 60.98 & 38.92 & 100.00 \\
\hline S28B & 2.73 & 0.31 & -0.74 & 5.22 & 0.00 & 0.00 & 2.85 & 83.37 & 13.77 & 100.00 \\
\hline S28A & 2.71 & 0.29 & -0.73 & 5.30 & 0.00 & 0.00 & 2.53 & 86.90 & 10.57 & 100.00 \\
\hline S28D & 2.81 & 0.27 & 0.08 & 4.86 & 0.00 & 0.00 & 0.54 & 80.30 & 19.16 & 100.00 \\
\hline S29B & 2.82 & 0.26 & 0.01 & 4.59 & 0.00 & 0.00 & 0.54 & 78.11 & 21.35 & 100.00 \\
\hline S29A & 2.86 & 0.26 & 0.59 & 3.78 & 0.00 & 0.00 & 0.06 & 74.50 & 25.44 & 100.00 \\
\hline S29D & 2.85 & 0.25 & 0.39 & 4.09 & 0.00 & 0.00 & 0.20 & 76.36 & 23.44 & 100.00 \\
\hline S30B & 2.80 & 0.29 & -0.76 & 8.08 & 0.00 & 0.11 & 1.01 & 79.33 & 19.55 & 100.00 \\
\hline S30A & 2.73 & 0.33 & -0.82 & 5.18 & 0.00 & 0.00 & 3.71 & 80.58 & 15.70 & 100.00 \\
\hline S30D & 2.80 & 0.26 & -0.03 & 4.80 & 0.00 & 0.00 & 0.52 & 81.58 & 17.90 & 100.00 \\
\hline S31B & 2.69 & 0.40 & -0.91 & 4.38 & 0.00 & 0.08 & 7.39 & 74.87 & 17.67 & 100.00 \\
\hline S31A & 2.82 & 0.25 & 0.18 & 4.23 & 0.00 & 0.00 & 0.24 & 79.52 & 20.24 & 100.00 \\
\hline S31D & 2.92 & 0.28 & 0.38 & 4.56 & 0.00 & 0.03 & 0.18 & 65.87 & 33.92 & 100.00 \\
\hline S32B & 2.82 & 0.30 & -0.44 & 4.42 & 0.00 & 0.00 & 1.24 & 74.76 & 24.00 & 100.00 \\
\hline S32A & 2.79 & 0.23 & 0.25 & 5.27 & 0.00 & 0.00 & 0.20 & 84.92 & 14.88 & 100.00 \\
\hline S32D & 2.78 & 0.26 & -0.23 & 4.94 & 0.07 & 0.09 & 0.74 & 83.08 & 16.18 & 100.00 \\
\hline
\end{tabular}


Praia da Ilha das Peças

\begin{tabular}{|c|c|c|c|c|c|c|c|c|c|c|}
\hline $\begin{array}{l}\text { código da } \\
\text { amostra }\end{array}$ & $\begin{array}{l}\text { diâmetro } \\
\text { médio }(\phi)\end{array}$ & $\begin{array}{l}\text { desvio } \\
\text { padrão }\end{array}$ & assimetria & curtose & \begin{tabular}{|c|} 
areia muito \\
grossa $(\mathrm{g})$ \\
\end{tabular} & \begin{tabular}{|c|} 
areia grossa \\
(g)
\end{tabular} & $\begin{array}{c}\text { areia média } \\
(\mathrm{g})\end{array}$ & areia lina (g) & $\begin{array}{c}\text { areia muito } \\
\text { lina }(\mathrm{g})\end{array}$ & $\begin{array}{l}\text { areia total } \\
\text { (g) }\end{array}$ \\
\hline P01 B & 2.77 & 0.26 & -0.54 & 6.98 & 0.00 & 0.00 & 1.42 & 84.72 & 13.86 & 100.00 \\
\hline P01A & 2.86 & 0.27 & 0.73 & 4.75 & 0.00 & 0.00 & 0.21 & 76.20 & 23.59 & 100.00 \\
\hline P01D & 2.77 & 0.26 & -0.54 & 6.98 & 0.00 & 0.00 & 1.42 & 84.72 & 13.86 & 100.00 \\
\hline P02B & 2.72 & 0.29 & -1.02 & 8.12 & 0.00 & 0.05 & 2.84 & 86.71 & 10.40 & 100.00 \\
\hline P02A & 2.82 & 0.26 & 0.28 & 6.58 & 0.00 & 0.01 & 0.58 & 81.34 & 18.07 & 100.00 \\
\hline P02D & 2.82 & 0.24 & 0.57 & 6.32 & 0.00 & 0.00 & 0.28 & 81.92 & 17.80 & 100.00 \\
\hline P(1)3B & 2.77 & 0.25 & -0.16 & 6.40 & 0.00 & 0.00 & 0.77 & 86.74 & 12.49 & 100.00 \\
\hline P03A & 2.90 & 0.30 & 0.69 & 4.08 & 0.00 & 0.00 & 0.24 & 69.94 & 29.82 & 100.00 \\
\hline P03D & 2.94 & 0.29 & 0.80 & 3.29 & 0.00 & 0.00 & 0.05 & 63.90 & 36.05 & 100.00 \\
\hline P04B & 2.70 & 0.37 & -0.98 & 4.61 & 0.00 & 0.01 & 6.73 & 77.36 & 15.90 & 100.00 \\
\hline P(14A & 2.88 & 0.23 & 1.17 & 3.33 & 0.00 & 0.00 & 0.00 & 74.05 & 25.95 & 100.00 \\
\hline$P(14 D$ & 2.85 & 0.24 & 0.70 & 3.97 & 0.00 & 0.00 & 0.06 & 76.57 & 23.37 & 100.00 \\
\hline P05B & 2.87 & 0.24 & 0.85 & 3.35 & 0.00 & 0.00 & 0.03 & 74.58 & 25.39 & 100.00 \\
\hline P05A & 2.75 & 0.27 & -0.66 & 6.25 & 0.00 & 0.00 & 1.56 & 85.36 & 13.08 & 100.00 \\
\hline P05D & 2.75 & 0.26 & -0.41 & 5.93 & 0.00 & 0.00 & 1.04 & 86.61 & 12.35 & 100.00 \\
\hline P06B & 2.85 & 0.24 & 0.55 & 3.78 & 0.00 & 0.00 & 0.11 & 77.12 & 22.77 & 100.00 \\
\hline P06A & 2.86 & 0.25 & 0.40 & 3.52 & 0.00 & 0.00 & 0.15 & 74.37 & 25.48 & 100.00 \\
\hline P07B & 2.90 & 0.26 & 0.03 & 3.97 & 0.00 & 0.02 & 0.17 & 66.47 & 33.34 & 100.00 \\
\hline P07A & 2.89 & 0.25 & 0.46 & 3.52 & 0.00 & 0.00 & 0.11 & 70.94 & 28.95 & 100.00 \\
\hline P(18B & 2.70 & 0.31 & -1.08 & 6.60 & 0.00 & 0.06 & 3.49 & 85.80 & 10.66 & 100.00 \\
\hline P(18A & 2.76 & 0.24 & -0.15 & 6.01 & 0.00 & 0.00 & 0.41 & 88.55 & 11.04 & 100.00 \\
\hline P(0)B & 2.91 & 0.28 & 0.09 & 3.14 & 0.00 & 0.00 & 0.24 & 65.47 & 34.29 & 100.00 \\
\hline P09A & 2.83 & 0.25 & 0.19 & 4.61 & 0.00 & 0.00 & 0.38 & 78.58 & 21.04 & 100.00 \\
\hline P10B & 2.71 & 0.32 & -0.82 & 5.18 & 0.00 & 0.01 & 3.54 & 84.44 & 12.02 & 100.00 \\
\hline P10A & 2.90 & 0.26 & 0.53 & 2.92 & 0.00 & 0.00 & 0.05 & 68.19 & 31.76 & 100.00 \\
\hline P10D & 2.83 & 0.24 & 0.71 & 4.60 & 0.00 & 0.00 & 0.07 & 80.15 & 19.78 & 100.00 \\
\hline P11B & 2.80 & 0.31 & -0.45 & 4.61 & 0.00 & 0.00 & 1.57 & 76.04 & 22.39 & 100.00 \\
\hline P11A & 2.86 & 0.26 & 0.14 & 3.84 & 0.00 & 0.00 & 0.35 & 73.00 & 26.65 & 100.00 \\
\hline P11D & 2.86 & 0.27 & -0.08 & 5.14 & 0.00 & 0.03 & 0.34 & 72.23 & 27.40 & 100.00 \\
\hline
\end{tabular}


Anexo 3. Análise de Correlação Linear dos parâmetros granulométricos

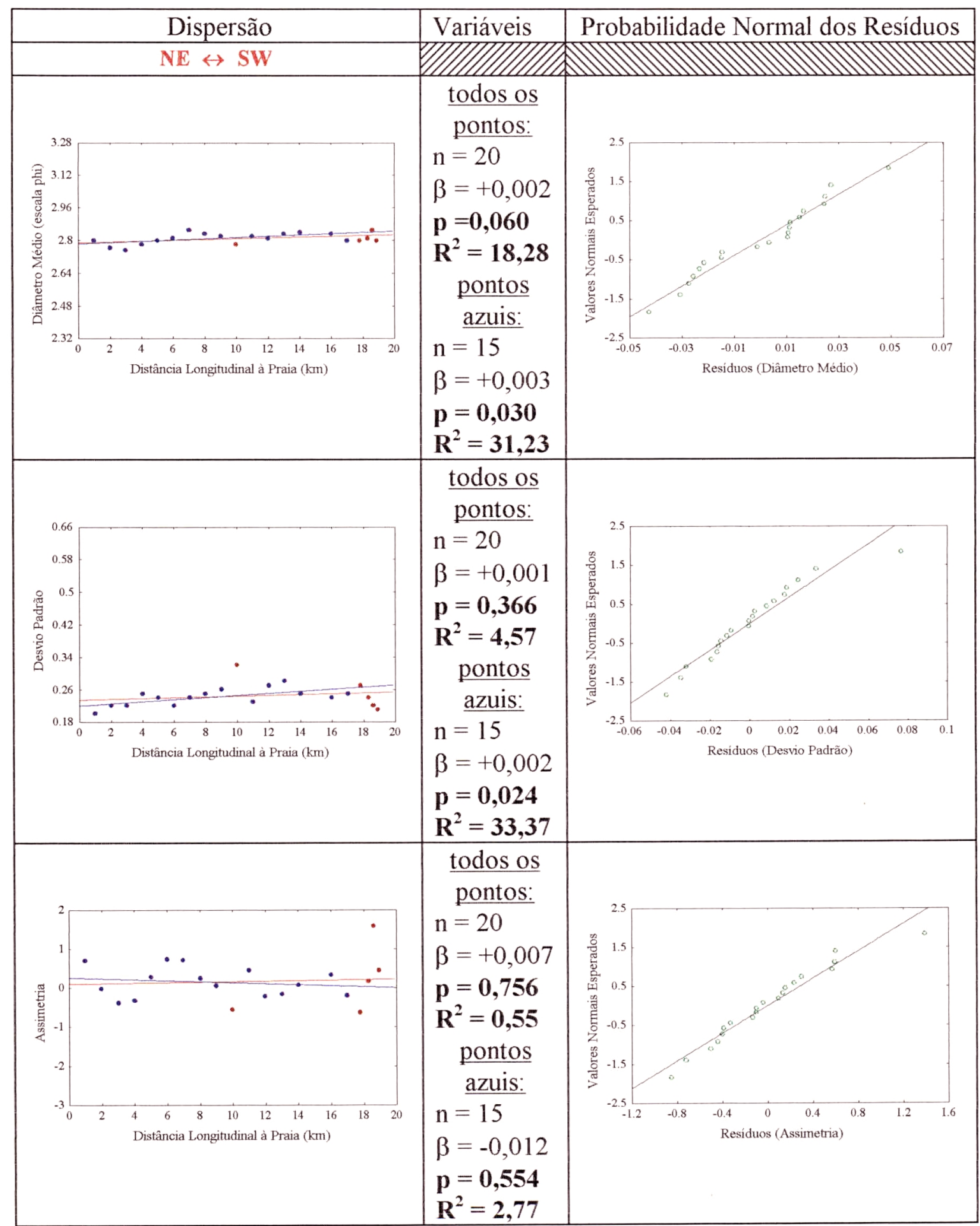

Tabela 3.1. Análise de Regressão Linear para as amostras coletadas na linha de maré baixa da Praia do Ararapira. As variáveis apresentadas são: $n=n^{0}$ de pontos; $\beta=$ inclinação da reta de equação $\mathrm{y}=\mathrm{a}+\beta \mathrm{x}$ do gráfico de dispersão dos valores; $\mathrm{R}^{2}=$ fator de correlação dos pontos $\left(0 \%<\mathrm{R}^{2}<100 \%\right) ; \mathrm{p}=$ probabilidade de que a hipótese da inclinação da reta seja igual a zero $(0<p<1$, sendo que somente são considerados satisfatórios valores de $p<0,05)$. Os pontos vermelhos representam os valores anômalos. 


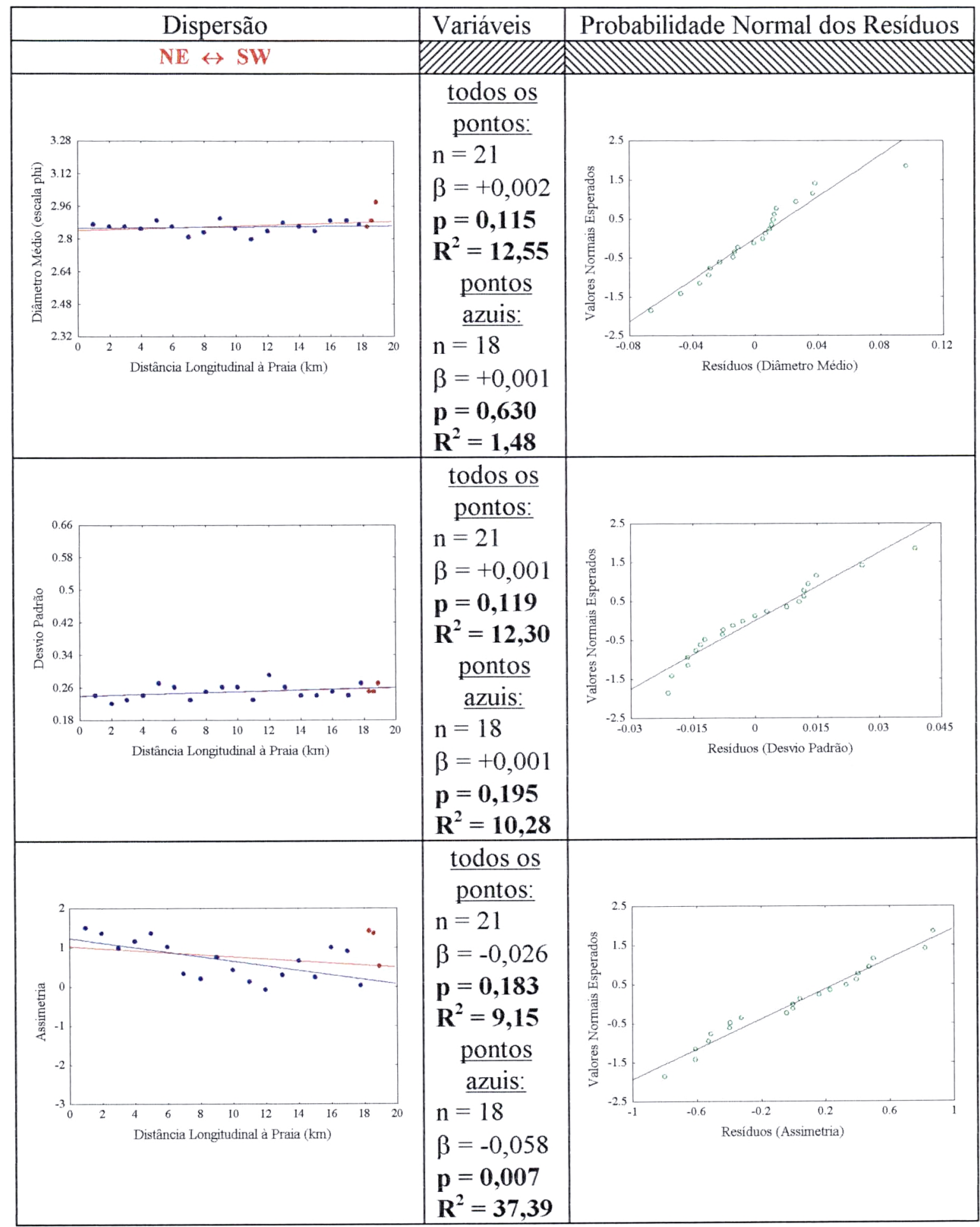

Tabela 3.2. Análise de Regressão Linear para alguns parâmetros granulométricos (diâmetro médio, desvio padrão e assimetria) das amostras coletadas na linha de maré alta relativa da Praia do Ararapira. As variáveis apresentadas são: $n=n^{\circ}$ de pontos; $\beta=$ inclinação da reta de equação $\mathrm{y}=\mathrm{a}+\beta \mathrm{x}$ do gráfico de dispersão dos valores; $\mathrm{R}^{2}=$ fator de correlação dos pontos $\left(0 \%<\mathrm{R}^{2}<100 \%\right) ; \mathrm{p}=$ probabilidade de que a hipótese da inclinação da reta seja igual a zero $(0<p<1$, sendo que somente são considerados satisfatórios valores de $p<0,05)$. Os pontos vermelhos representam os valores anômalos. 


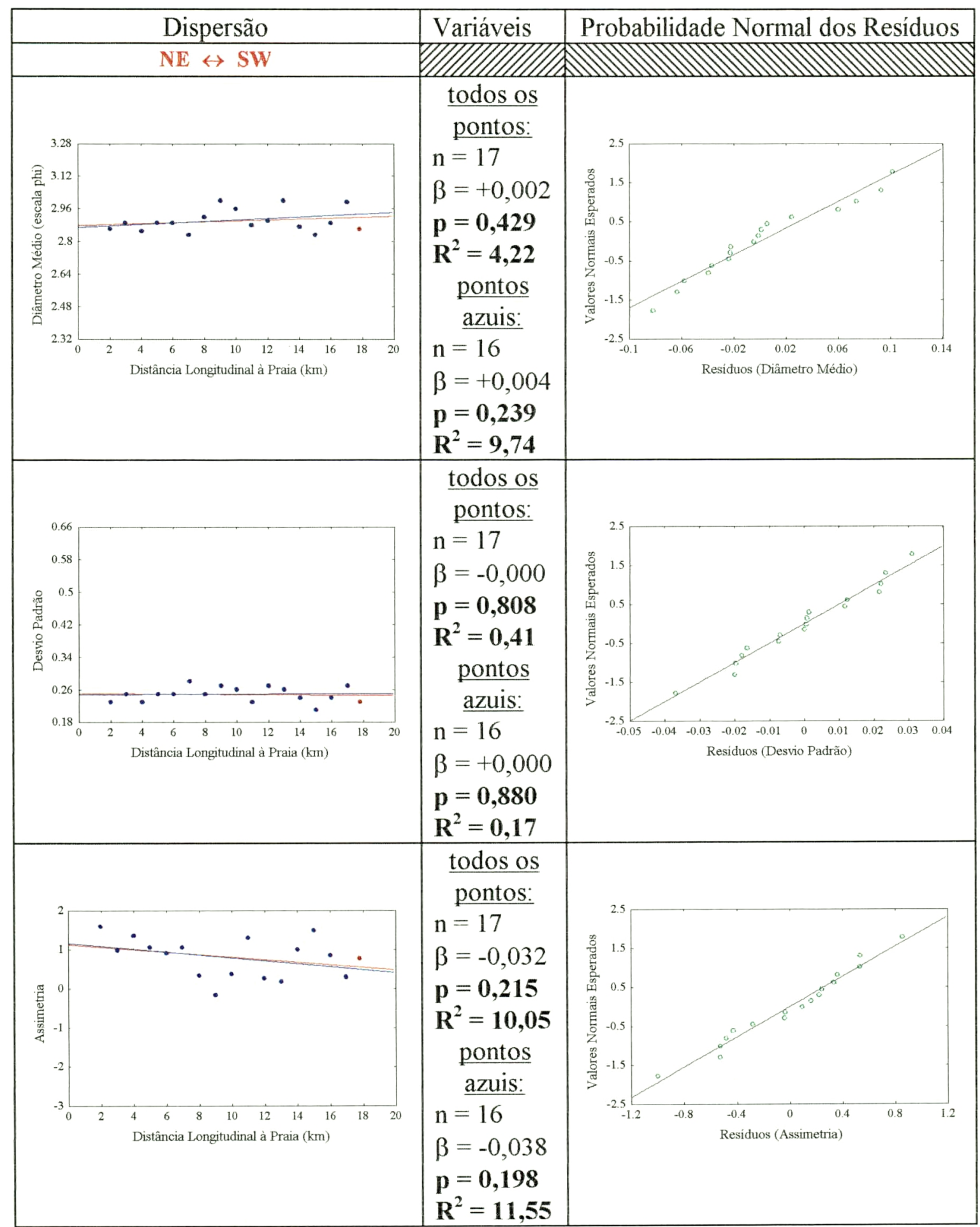

Tabela 3.3. Análise de Regressão Linear para alguns parâmetros granulométricos (diâmetro médio, desvio padrão e assimetria) das amostras coletadas na base do cordão de dunas frontais da Praia do Ararapira. As variáveis apresentadas são: $n=n^{0}$ de pontos; $\beta=$ inclinação da reta de equação $y=a+\beta x$ do gráfico de dispersão dos valores; $R^{2}=$ fator de correlação dos pontos $\left(0 \%<\mathrm{R}^{2}<100 \%\right) ; \mathrm{p}=$ probabilidade de que a hipótese da inclinação da reta seja igual a zero $(0<\mathrm{p}<1$, sendo que somente são considerados satisfatórios valores de $\mathrm{p}<0,05)$. Os pontos vermelhos representam os valores anômalos. 


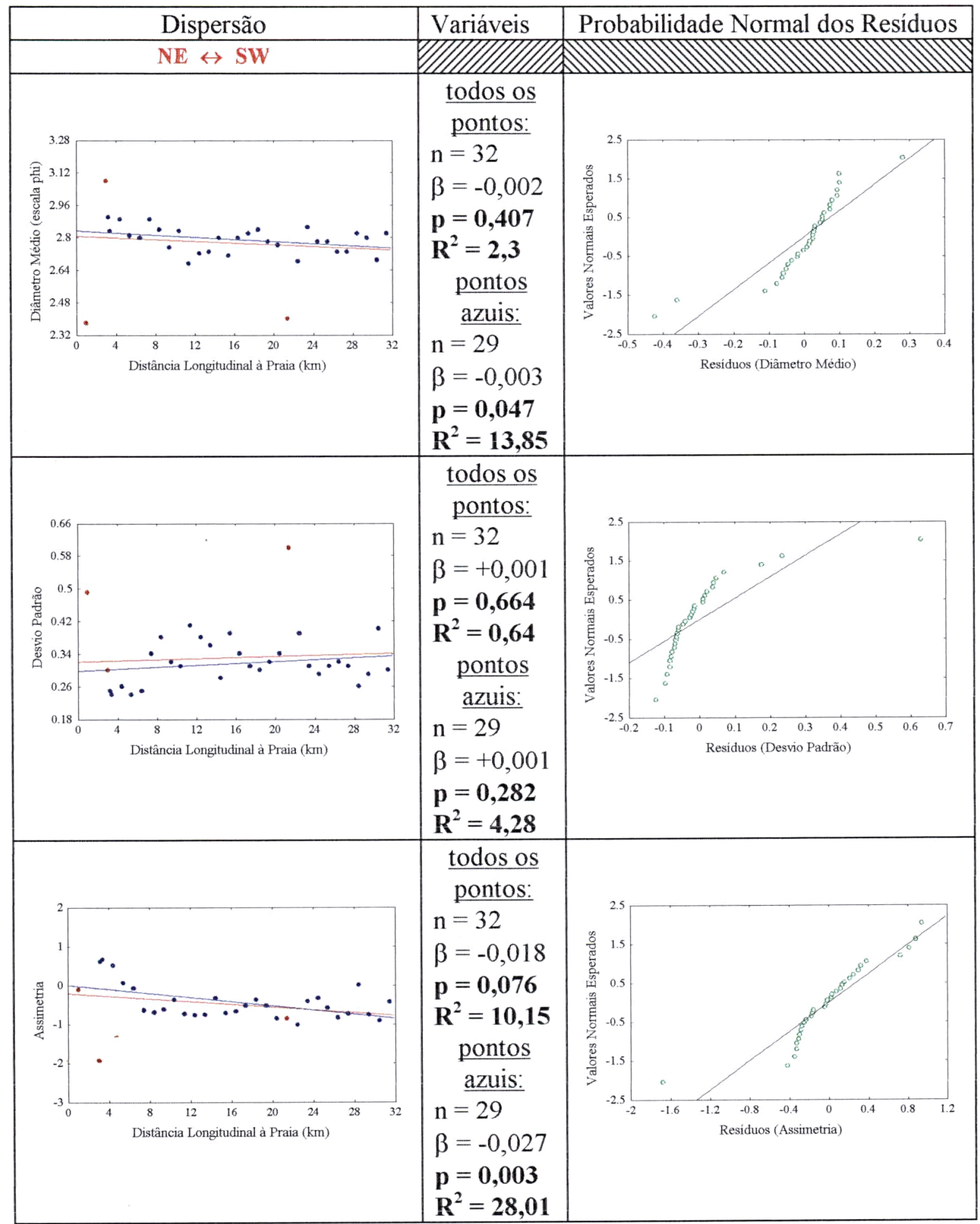

Tabela 3.4. Análise de Regressão Linear para alguns parâmetros granulométricos (diâmetro médio,desvio padrão e assimetria) das amostras coletadas na linha de maré baixa da praia da Ilha do Superaguii. As variáveis apresentadas são: $n=n^{\circ}$ de pontos; $\beta=$ inclinação da reta de equação $\mathrm{y}=\mathrm{a}+\beta \mathrm{x}$ do gráfico de dispersão dos valores; $\mathrm{R}^{2}=$ fator de correlação dos pontos $\left(0 \%<\mathrm{R}^{2}<100 \%\right) ; \mathrm{p}=$ probabilidade de que a hipótese da inclinação da reta seja igual a zero $(0<\mathrm{p}<1$, sendo que somente são considerados satisfatórios valores de $\mathrm{p}<0,05)$. Os pontos vermelhos representam os valores anômalos. 


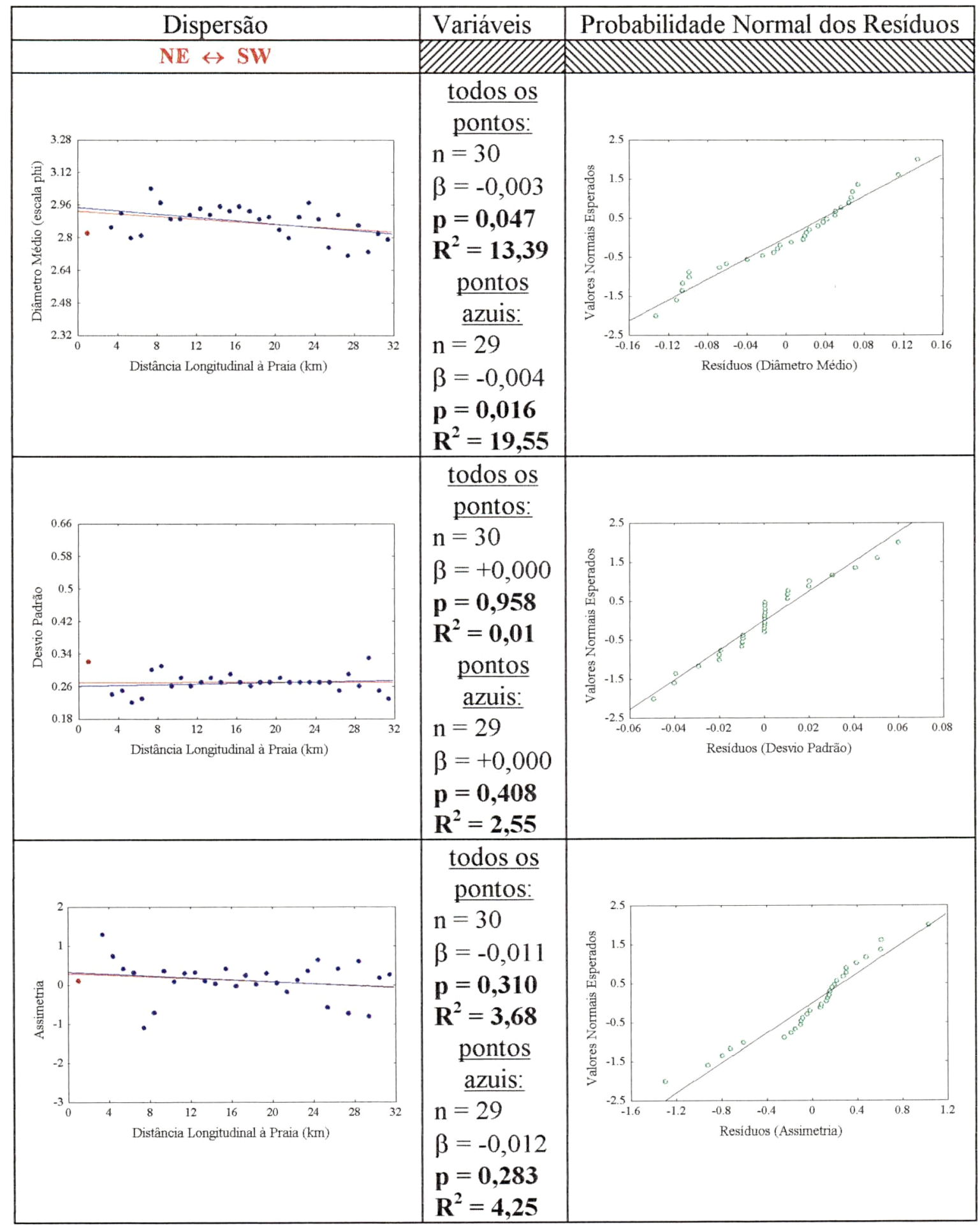

Tabela 3.5. Análise de Regressão Linear para alguns parâmetros granulométricos (diâmetro médio,desvio padrão e assimetria) das amostras coletadas na linha de maré alta relativa da praia da Ilha do Superagüi. As variáveis apresentadas são: $n=n^{\circ}$ de pontos; $\beta=$ inclinação da reta de equação $\mathrm{y}=\mathrm{a}+\beta \mathrm{x}$ do gráfico de dispersão dos valores; $\mathrm{R}^{2}=$ fator de correlação dos pontos $\left(0 \%<\mathrm{R}^{2}<100 \%\right) ; \mathrm{p}=$ probabilidade de que a hipótese da inclinação da reta seja igual a zero $(0<p<1$, sendo que somente são considerados satisfatórios valores de $p<0,05)$. Os pontos vermelhos representam os valores anômalos. 


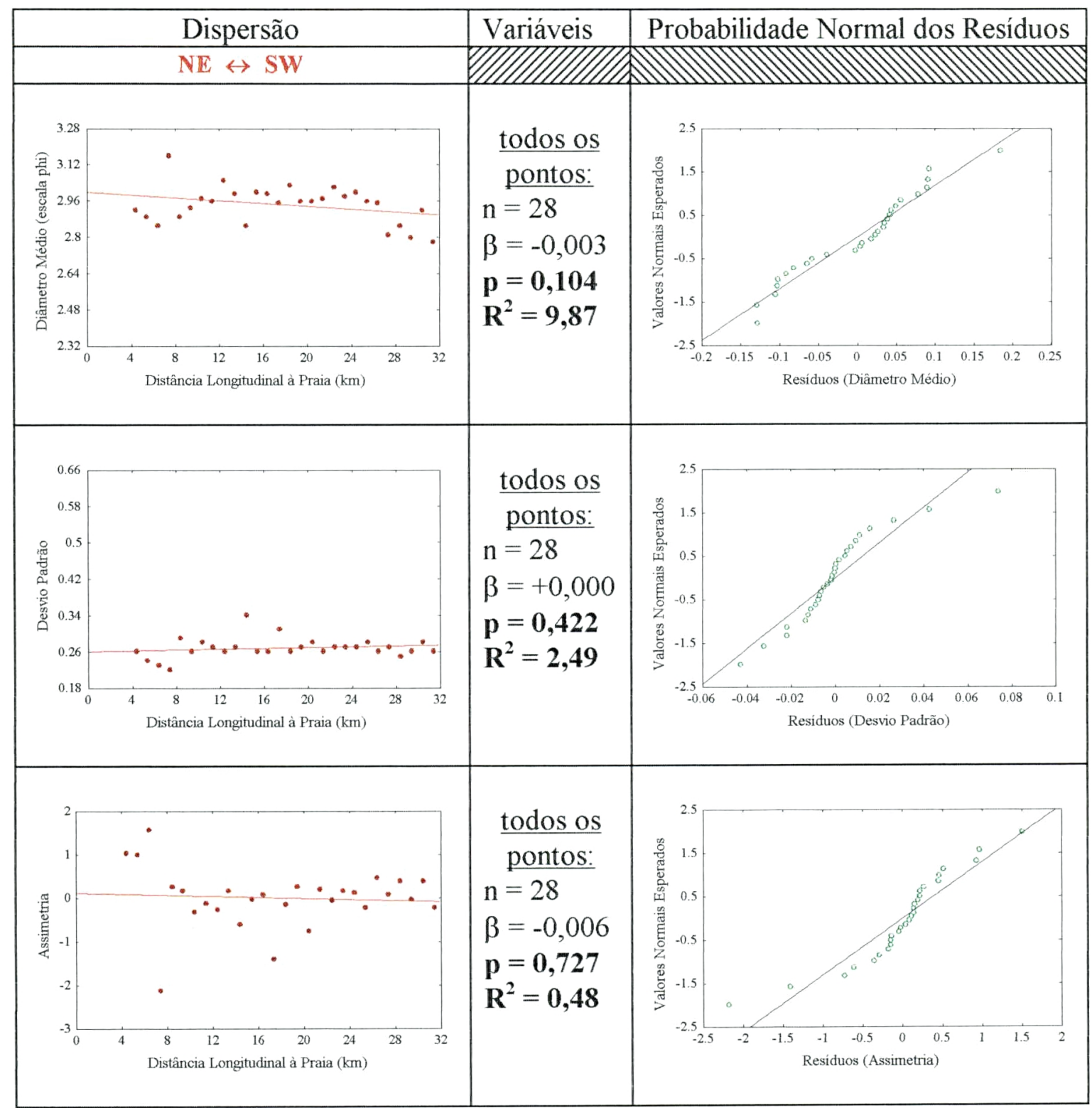

Tabela 3.6. Análise de Regressão Linear para alguns parâmetros granulométricos (diâmetro médio,desvio padrão e assimetria) das amostras coletadas na base do cordão de dunas frontais da praia da Ilha do Superagüi. As variáveis apresentadas são: $\mathrm{n}=\mathrm{n}^{\mathrm{o}}$ de pontos; $\beta=$ inclinação da reta de equação $y=a+\beta x$ do gráfico de dispersão dos valores; $\mathrm{R}^{2}=$ fator de correlação dos pontos $\left(0 \%<\mathrm{R}^{2}<100 \%\right) ; \mathrm{p}=$ probabilidade de que a hipótese da inclinação da reta seja igual a zero $(0<\mathrm{p}<1$, sendo que somente são considerados satisfatórios valores de $\mathrm{p}<0,05)$. 


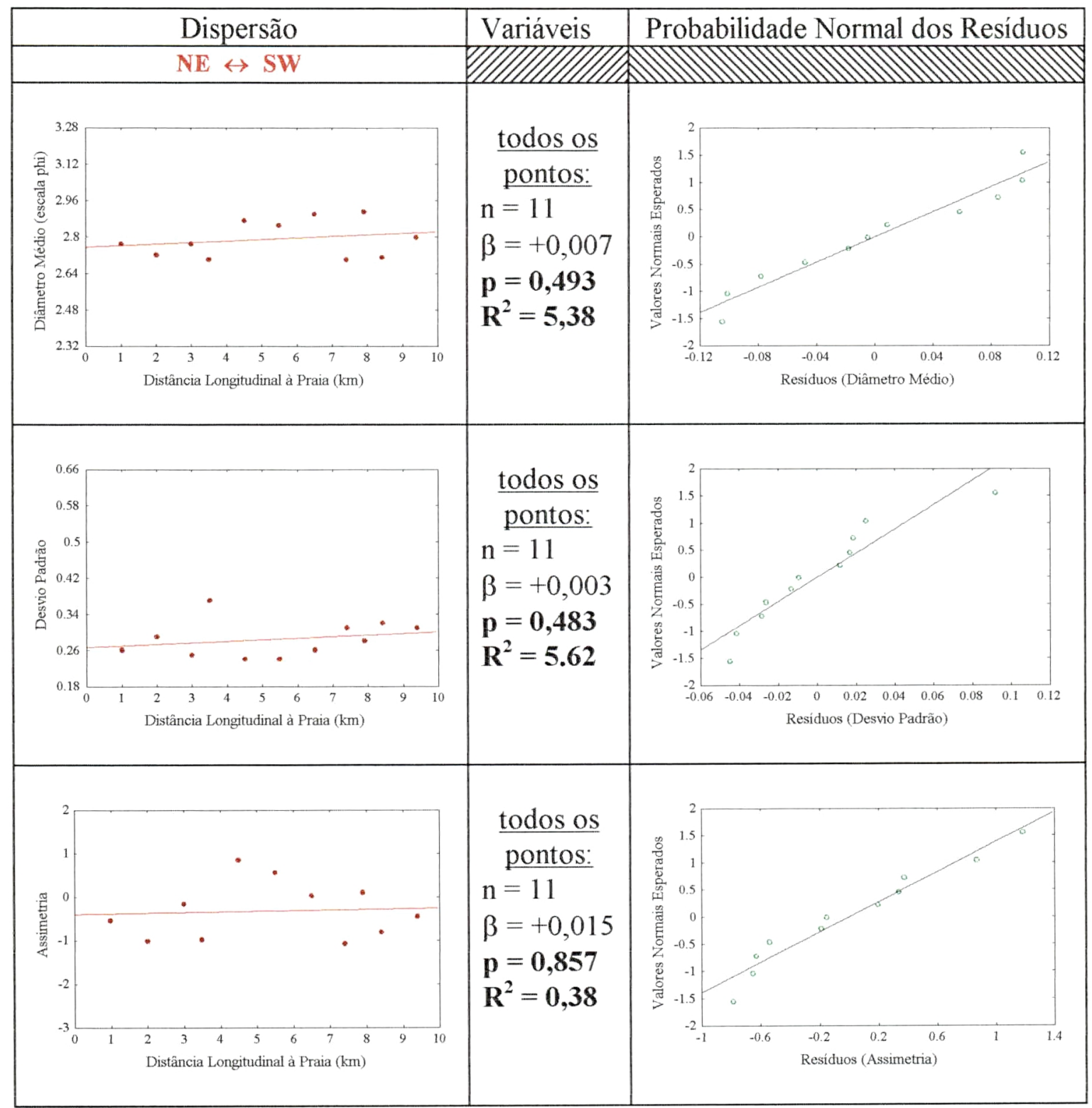

Tabela 3.7. Análise de Regressão Linear para alguns parâmetros granulométricos (diâmetro médio,desvio padrão e assimetria) das amostras coletadas na linha de maré baixa da praia da Ilha das Peças. As variáveis apresentadas são: $n=n^{0}$ de pontos; $\beta=$ inclinação da reta de equação $\mathrm{y}=\mathrm{a}+\beta \mathrm{x}$ do gráfico de dispersão dos valores; $\mathrm{R}^{2}=$ fator de correlação dos pontos $\left(0 \%<\mathrm{R}^{2}<100 \%\right) ; \mathrm{p}=$ probabilidade de que a hipótese da inclinação da reta seja igual a zero $(0<p<1$, sendo que somente são considerados satisfatórios valores de $p<0,05)$. 


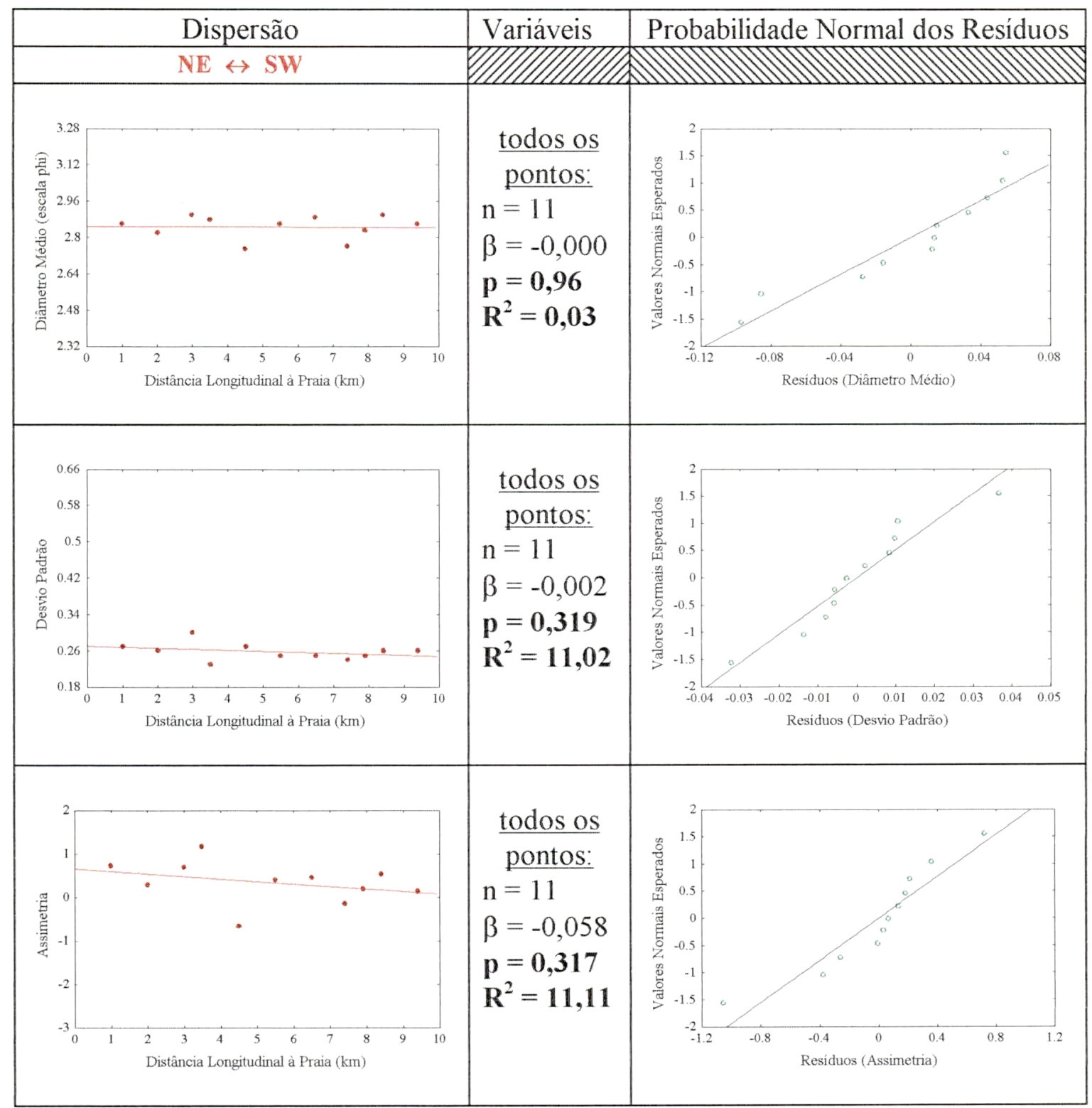

Tabela 3.8. Análise de Regressão Linear para alguns parâmetros granulométricos (diâmetro médio,desvio padrão e assimetria) das amostras coletadas na linha de maré alta relativa da praia da Ilha das Peças. As variáveis apresentadas são: $n=n^{\circ}$ de pontos; $\beta=$ inclinação da reta de equação $\mathrm{y}=\mathrm{a}+\beta \mathrm{x}$ do gráfico de dispersão dos valores; $\mathrm{R}^{2}=$ fator de correlação dos pontos $\left(0 \%<\mathrm{R}^{2}<100 \%\right) ; \mathrm{p}=$ probabilidade de que a hipótese da inclinação da reta seja igual a zero $(0<p<1$, sendo que somente são considerados satisfatórios valores de $p<0,05)$. 


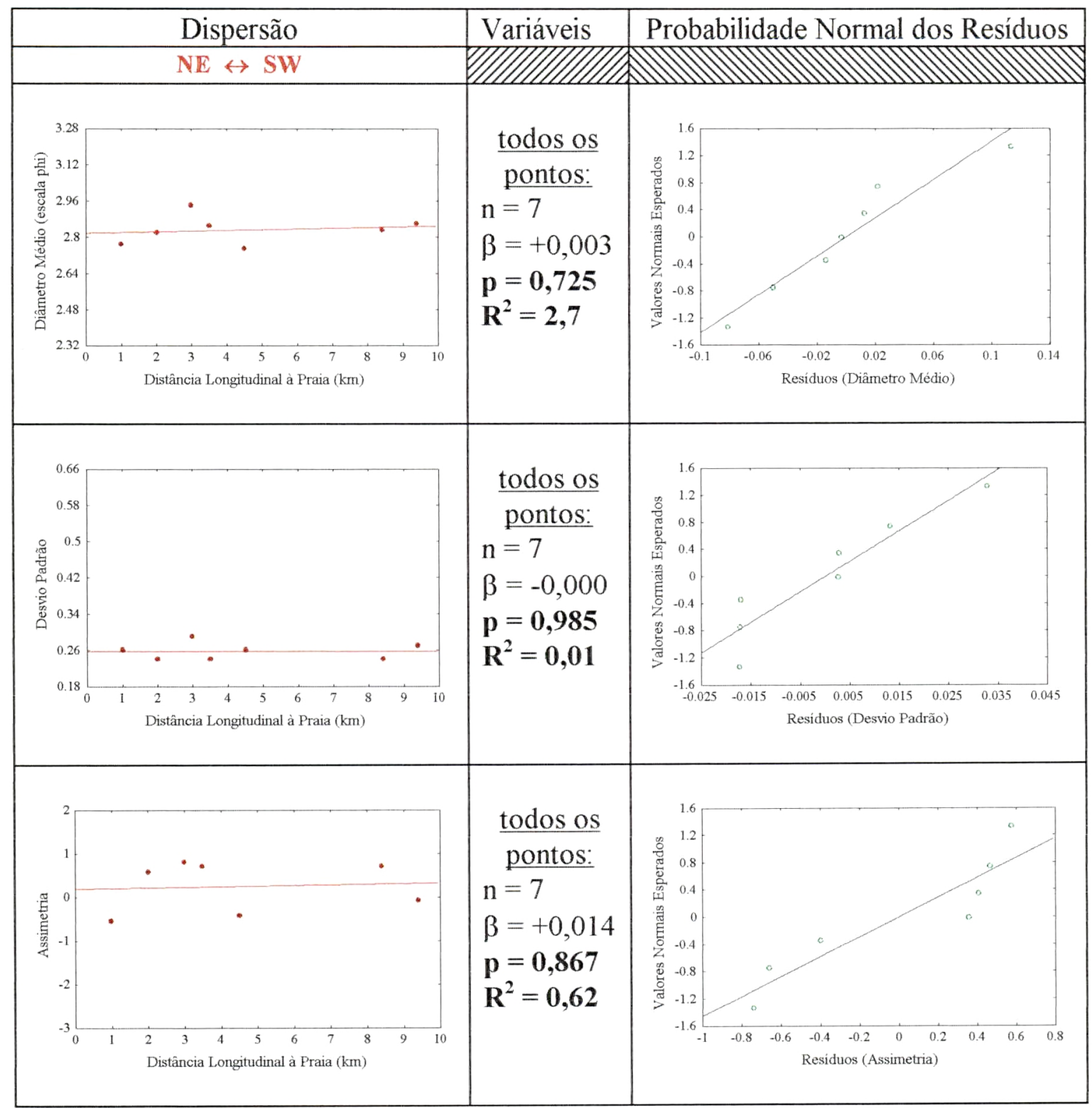

Tabela 3.9. Análise de Regressão Linear para alguns parâmetros granulométricos (diâmetro médio,desvio padrão e assimetria) das amostras coletadas na base do cordão de dunas frontais da praia da Ilha das Peças. As variáveis apresentadas são: $n=n^{\circ}$ de pontos; $\beta=$ inclinação da reta de equação $y=a+\beta x$ do gráfico de dispersão dos valores; $R^{2}=$ fator de correlação dos pontos $\left(0 \%<\mathrm{R}^{2}<100 \%\right) ; \mathrm{p}=$ probabilidade de que a hipótese da inclinação da reta seja igual a zero $(0<\mathrm{p}<1$, sendo que somente são considerados satisfatórios valores de $\mathrm{p}<0,05)$. 


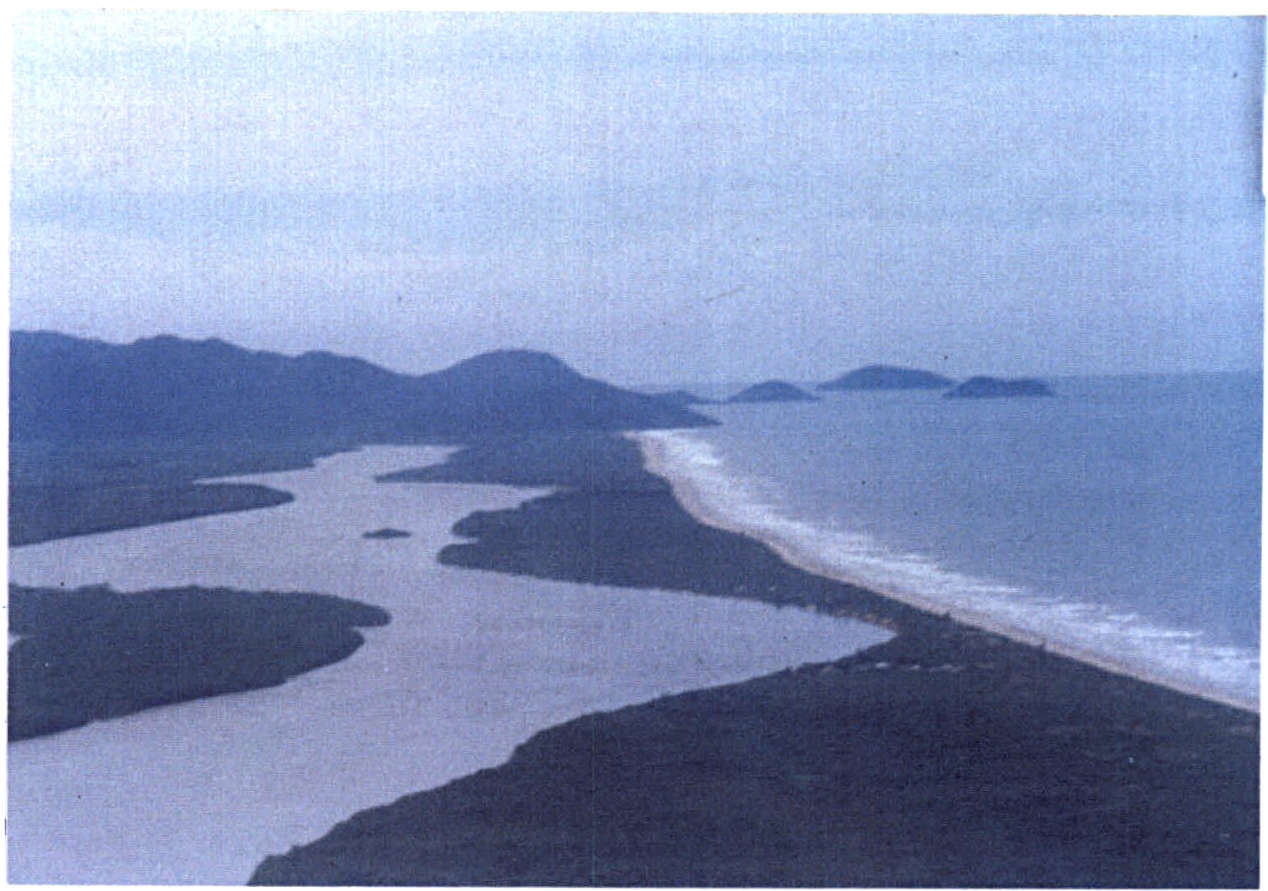

Foto 3.1.1. Vista aérea do Mar do Ararapira em abril de 1992 (Angulo,R.J.; DEGEO-UFPR)

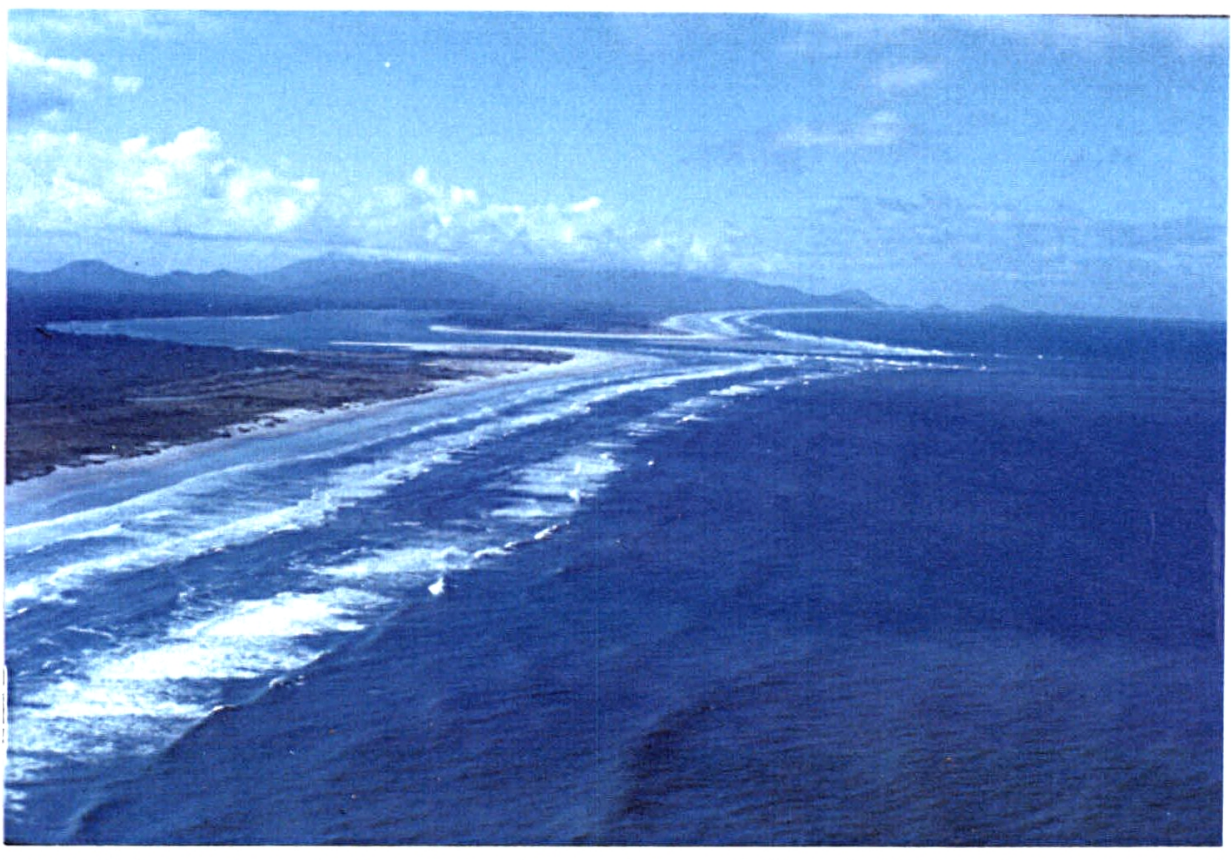

Foto 3.1.2. Vista aérea da Barra do Ararapira em julho de 1994. A margem inferior corresponde à Ilha do Superagüi e a superior, à Ilha do Cardoso (Angulo, R.J.; DEGEOUFPR) 


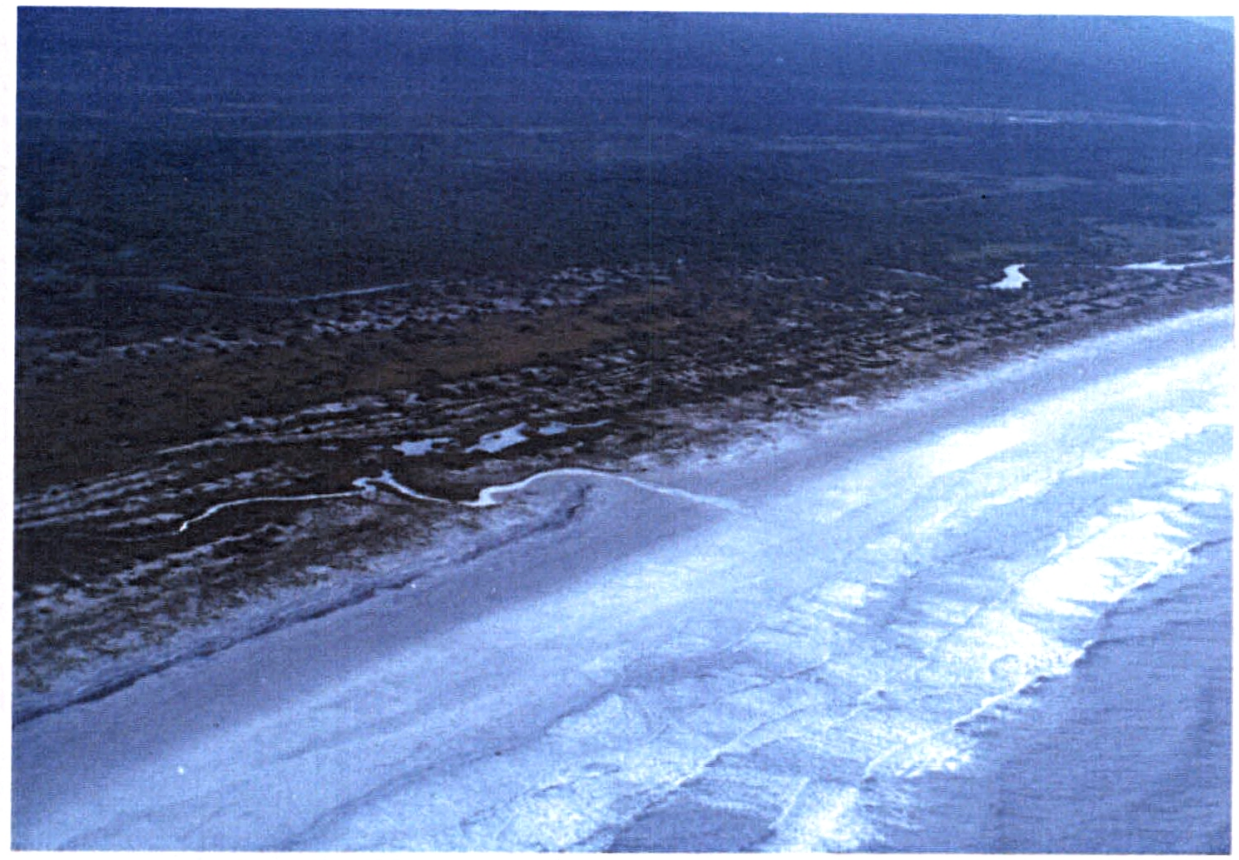

Foto 3.3.1. Vista acrea de parte da Praia Deserta, na Ilha do Superagüi, em jullho de 1994 Notar a presença de riachos desaguando na praia. (Angulo,R.J.; DEGEO-UFPR)

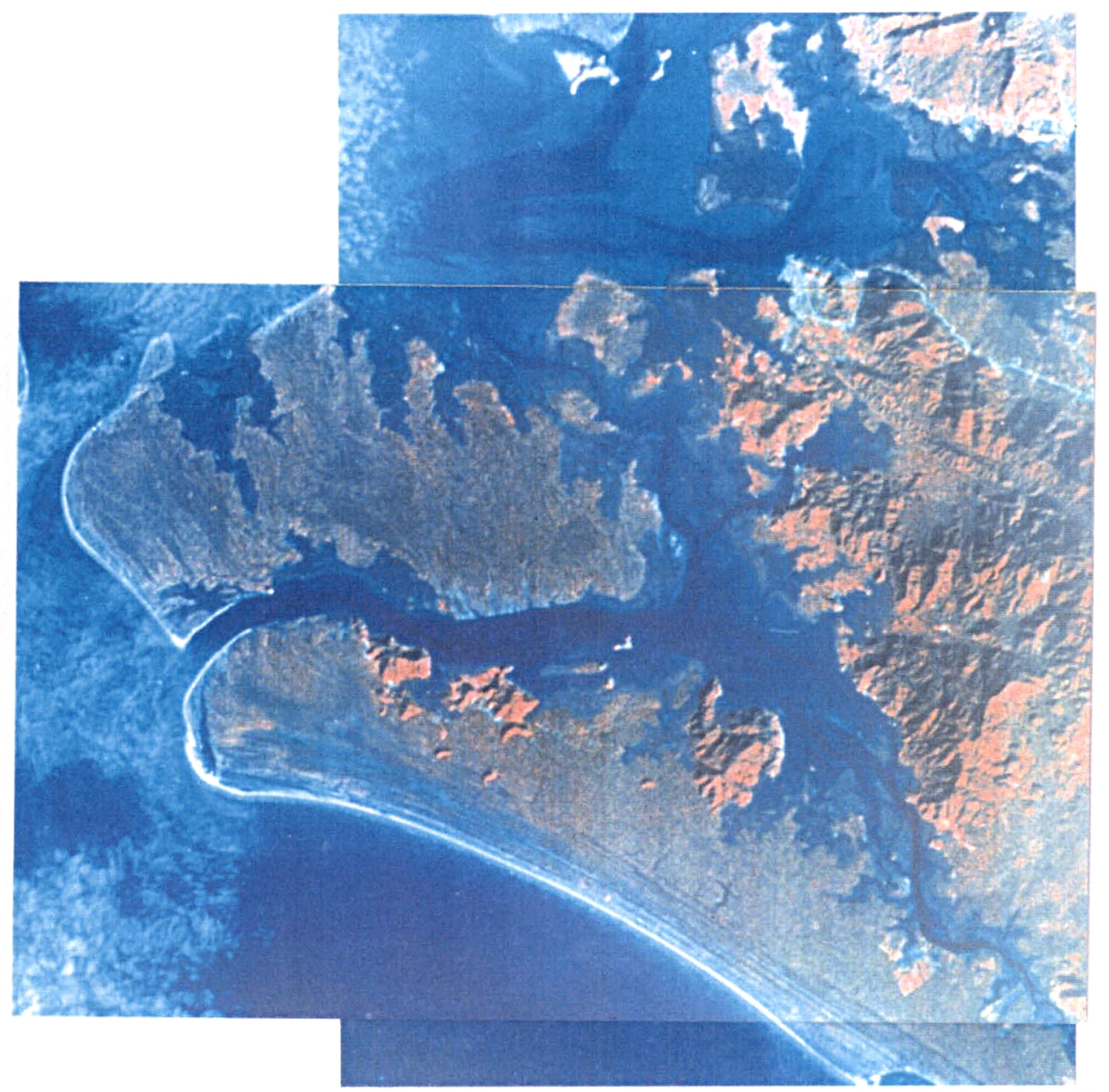

Foto 3.4.1. Cordões litorâneos da porção norte da planície costeira do Paraná. Foto tirada a partir de imagens de satélite de outubro de 1987. (Lessa,G.; IG-UFBA) 


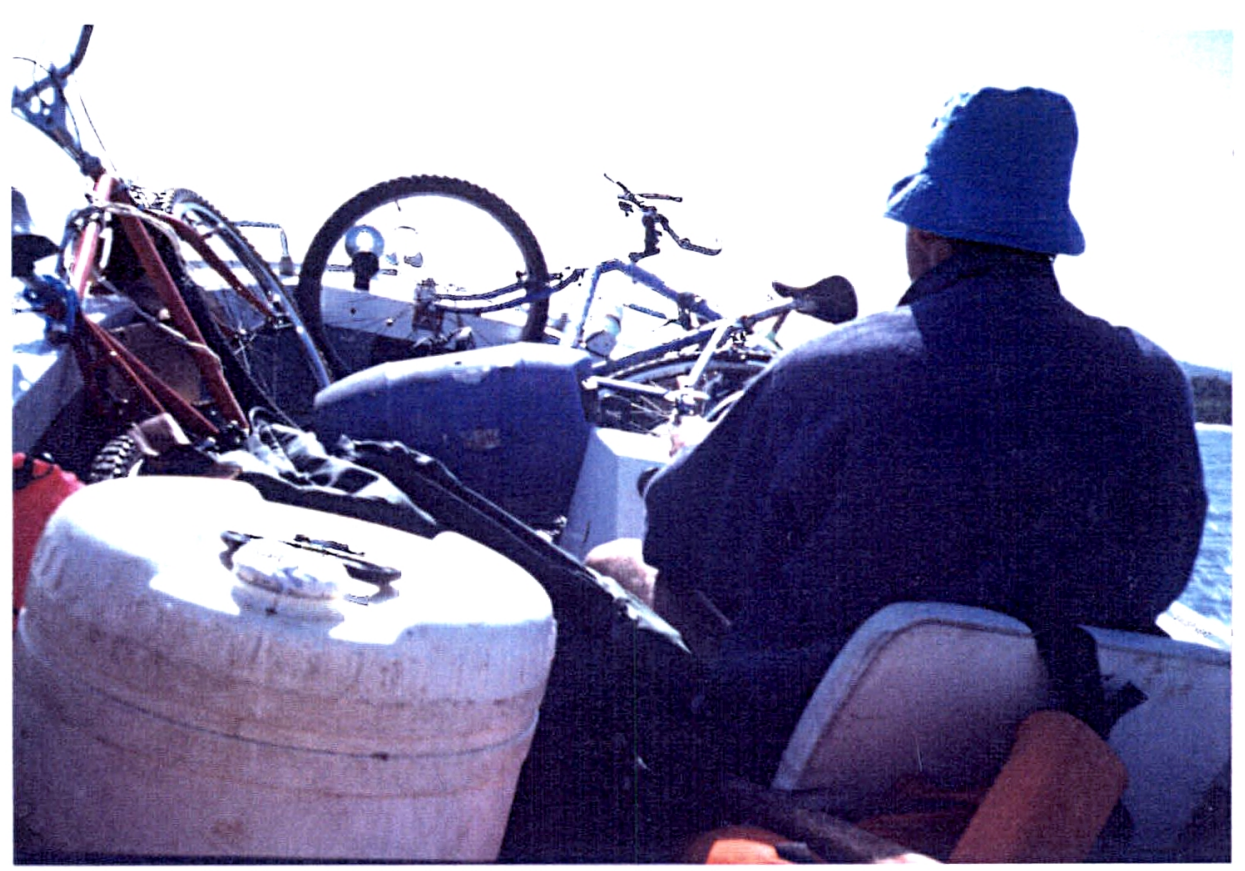

Foto 4.1.1.1. Meios de transporte pata os trabalhos de campo.

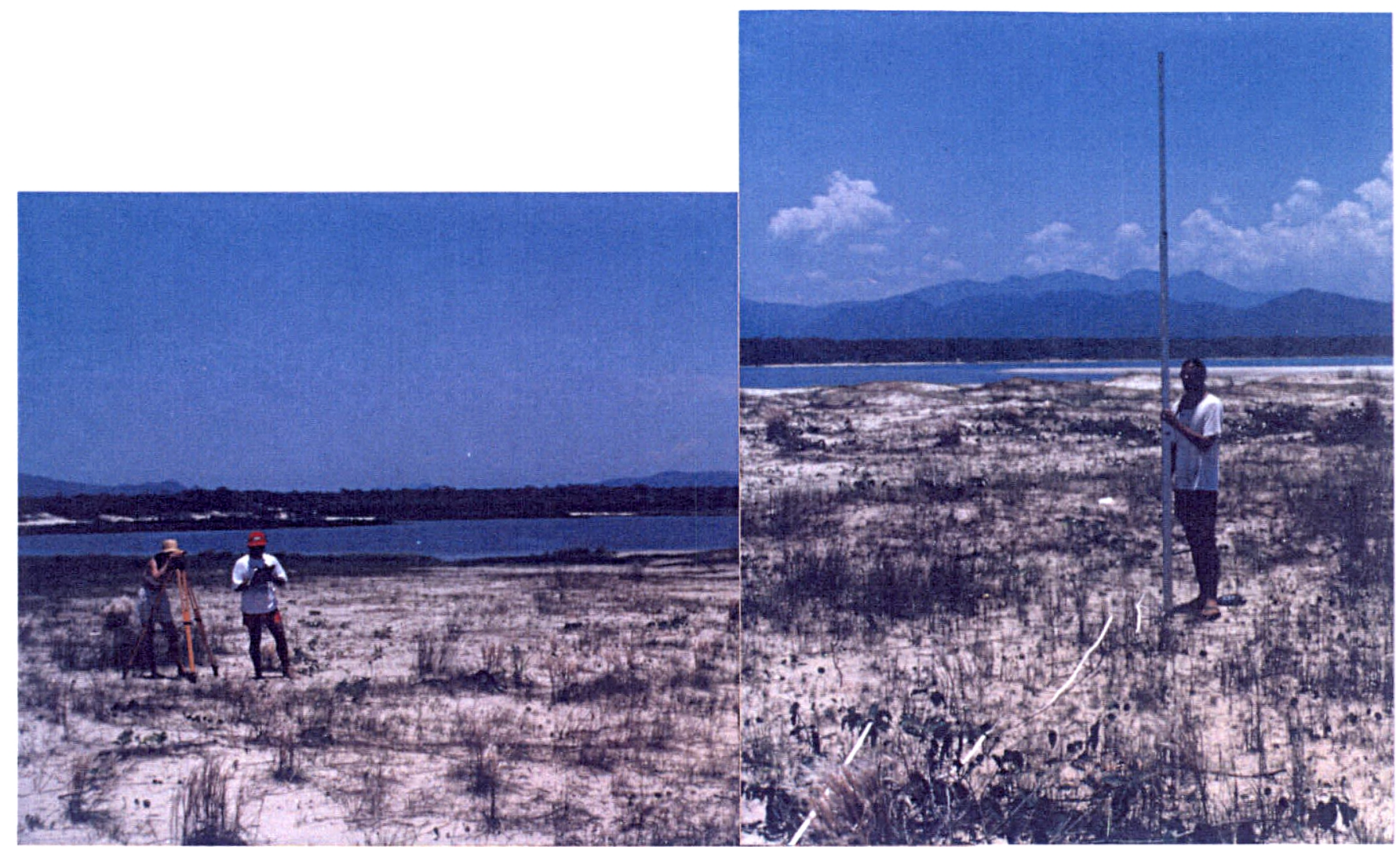

Foto 4.2.1.1. Procedimento dos levantamentos topográficos nas margens da desembocadura lagunar do Ararapira. Utilização de Nivel de Precisão (à esquerda) e Mira e Trena (à direita). (Angulo,R.J.; DEGEO-UFPR). 


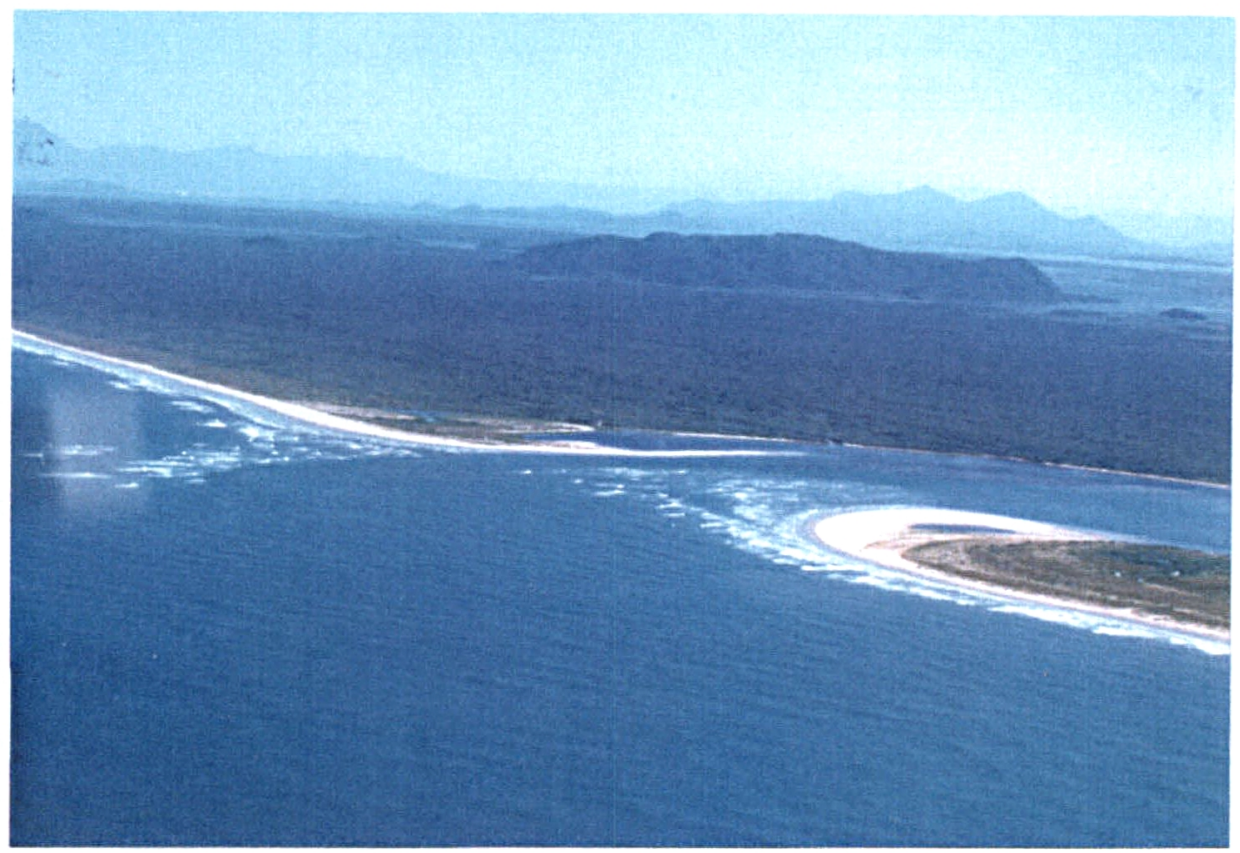

Foto 6.3.1. Vista aerea da Barra do Ararapira em 1996. A direita observa-se, a margem Ilha do Cardoso e à esquerda, observa-se a margem Ilha do Superagüi com o crescimento de um esporão arenoso que encerra uma pequena enseada. (Lessa, G.; IG-UFBA)

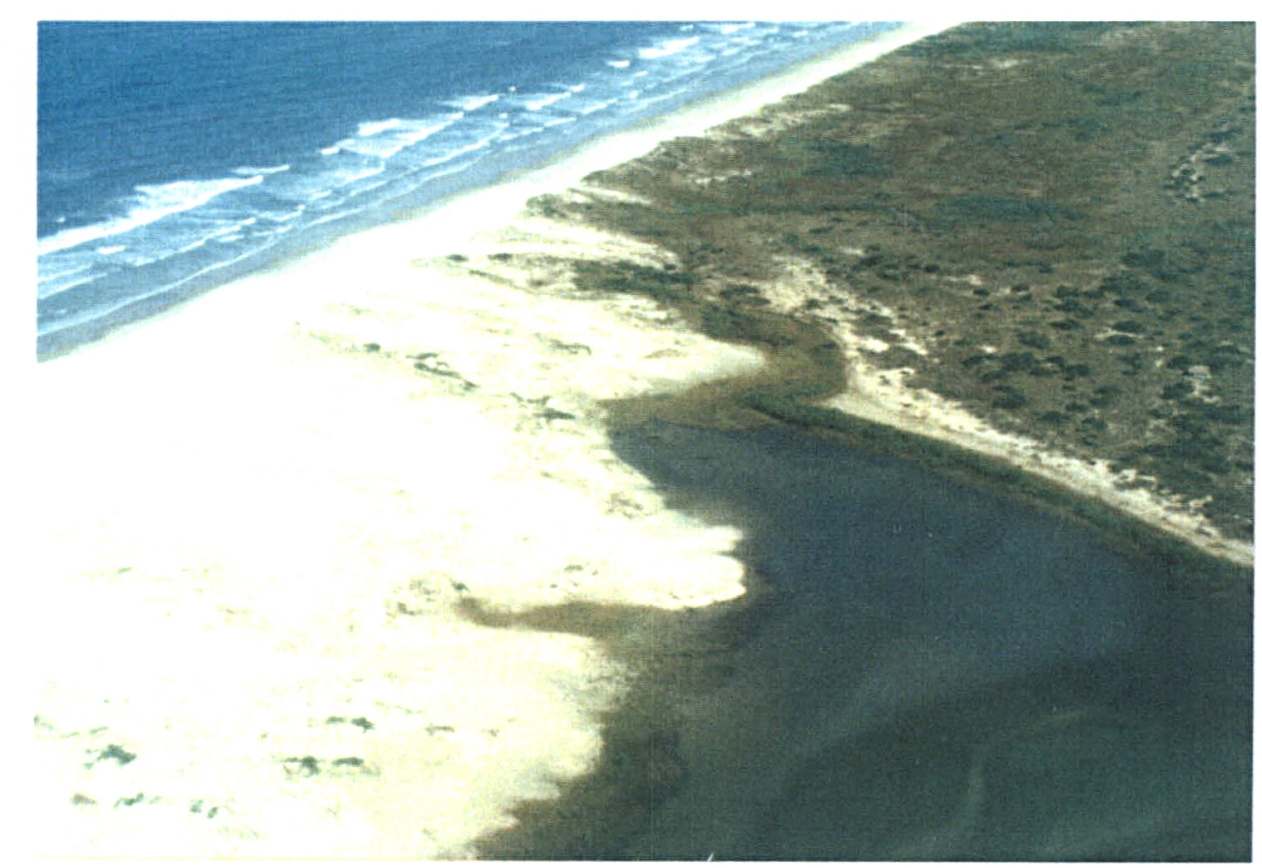

Foto 6.3.1.1. Vista aérea dos leques de sobrelavagem, em abril de 1992, na margem Itha do Superagüi (autor: Angulo, DEGEO-UFPR). 
Foto 6.3.1.2. Em primeiro plano observa-se o cordão dunar frontal e ao fundo, o campo de dunas frontais, dômicas e isoladas na margem Ilha do Superagüi.

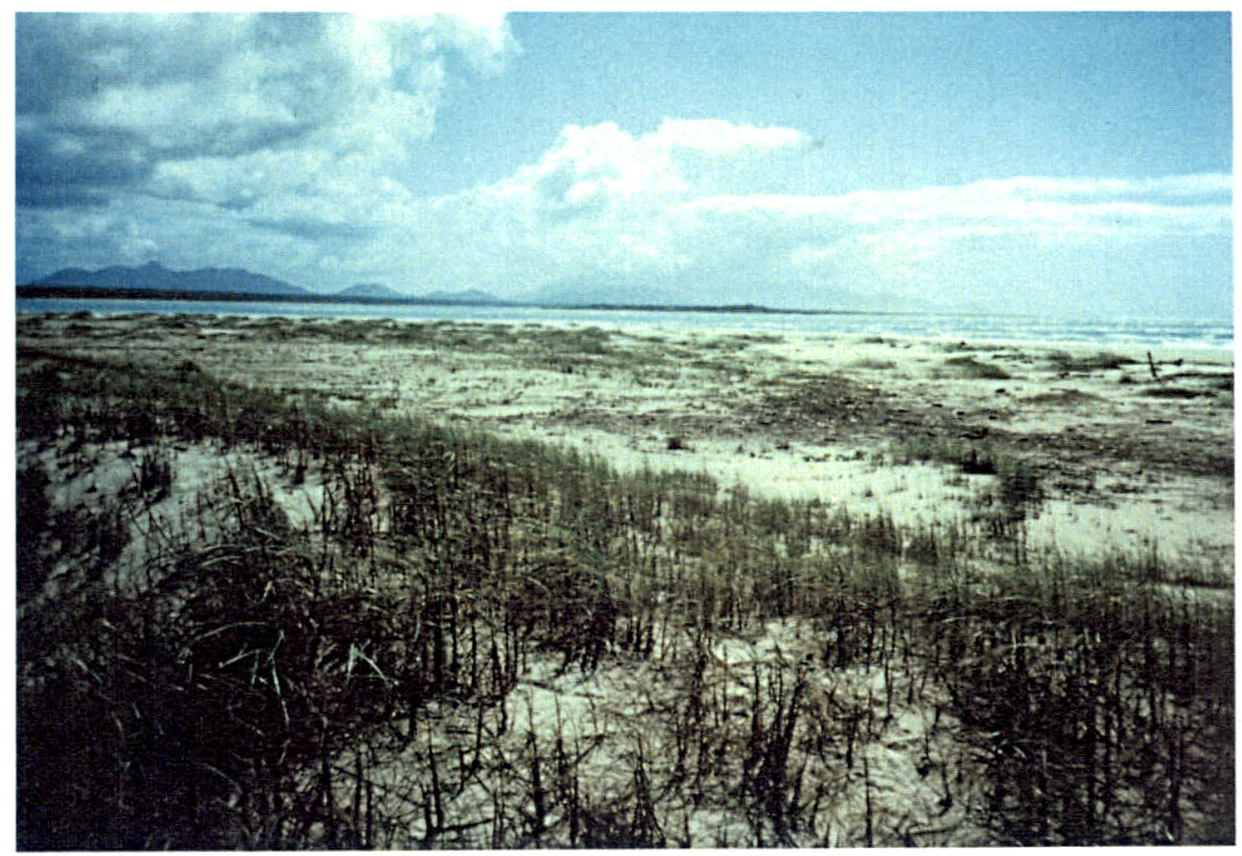

Foto 6.3.1.3.

Marcas erosivas do tipo falésias, com aproximadamente $50 \mathrm{~cm}$, na margem Ilha do Superagüi.

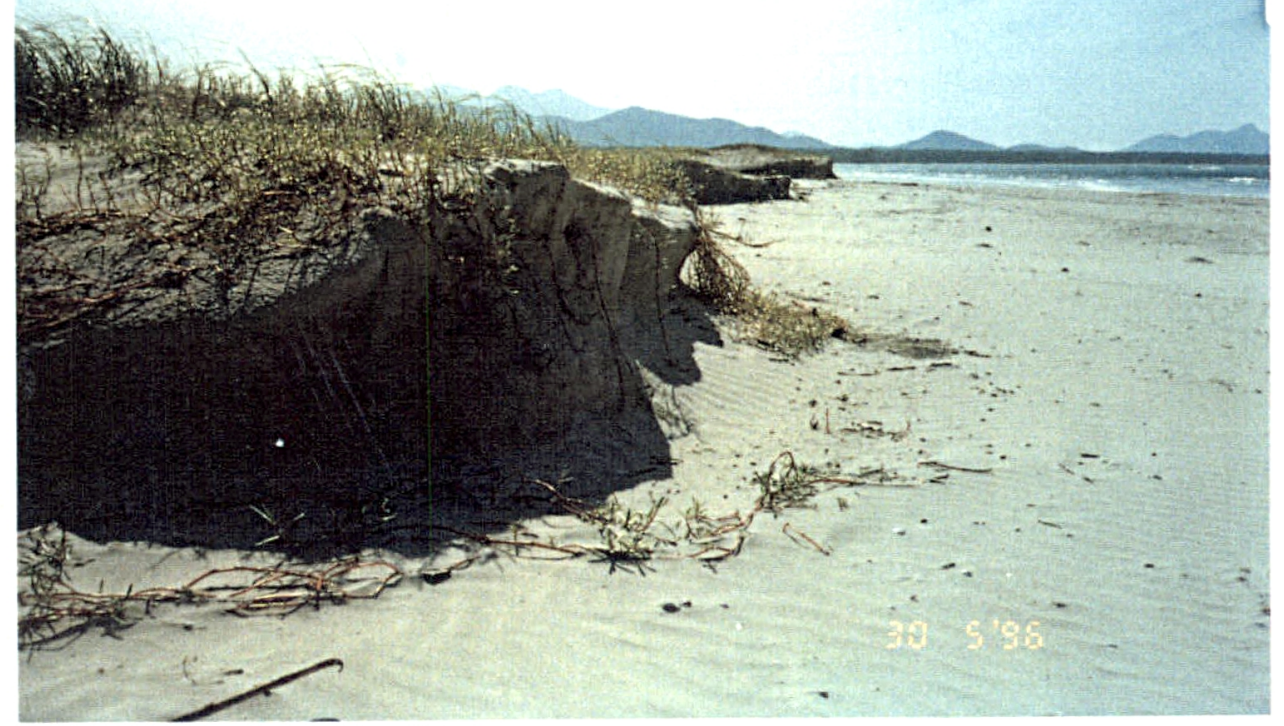

Foto 6.3.2.1

Presença de feições de sobrelavagem na margem

Ilha do Superagüii.

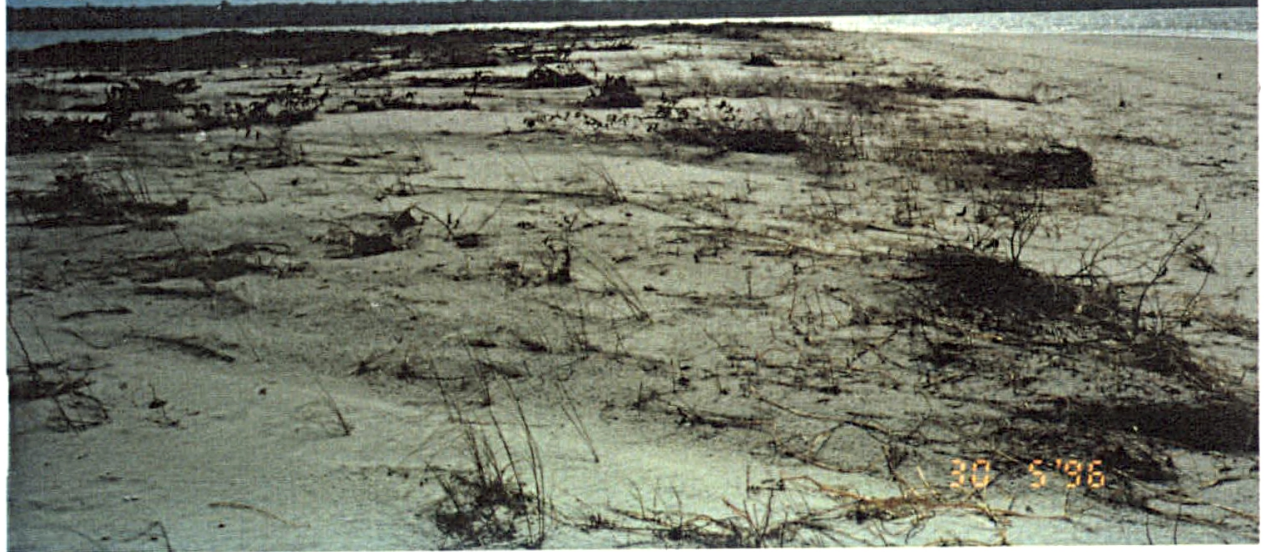




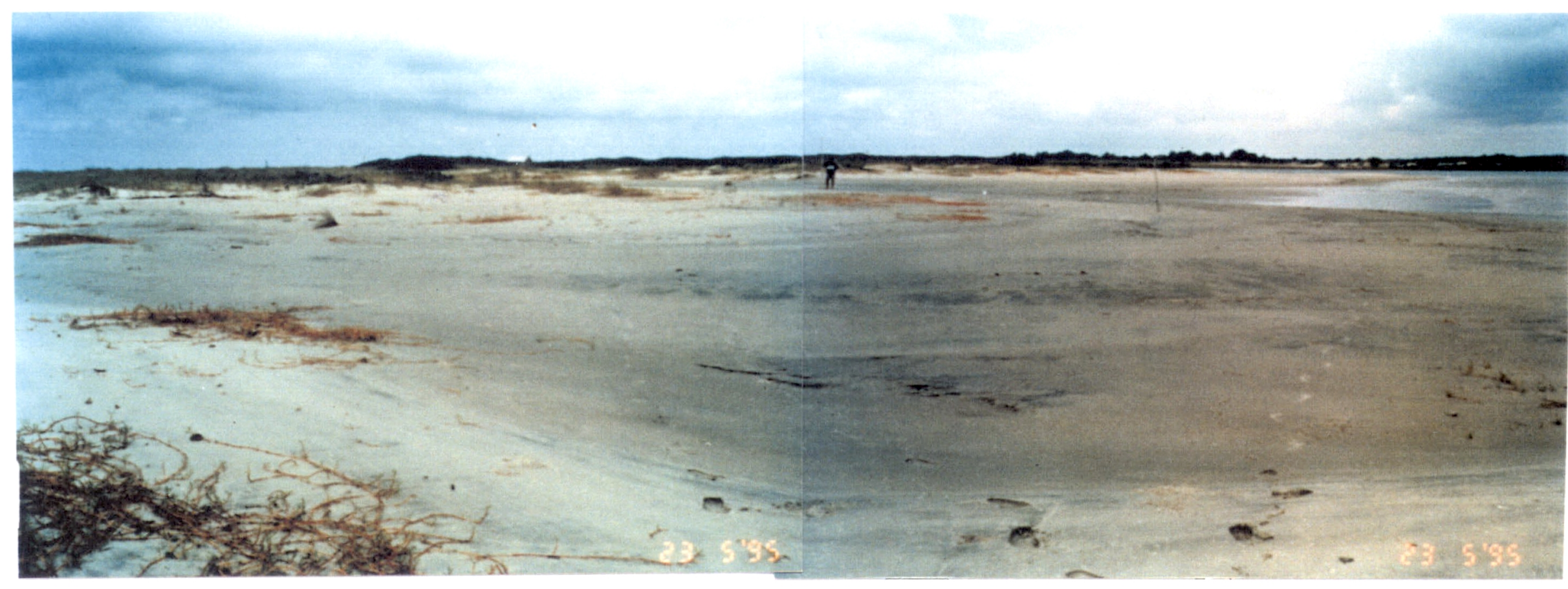

Foto 6.3.3.1. Erosão provocada pela circulação das correntes de maré durante períodos de preamar, na margem Ilha do Superagüi. 


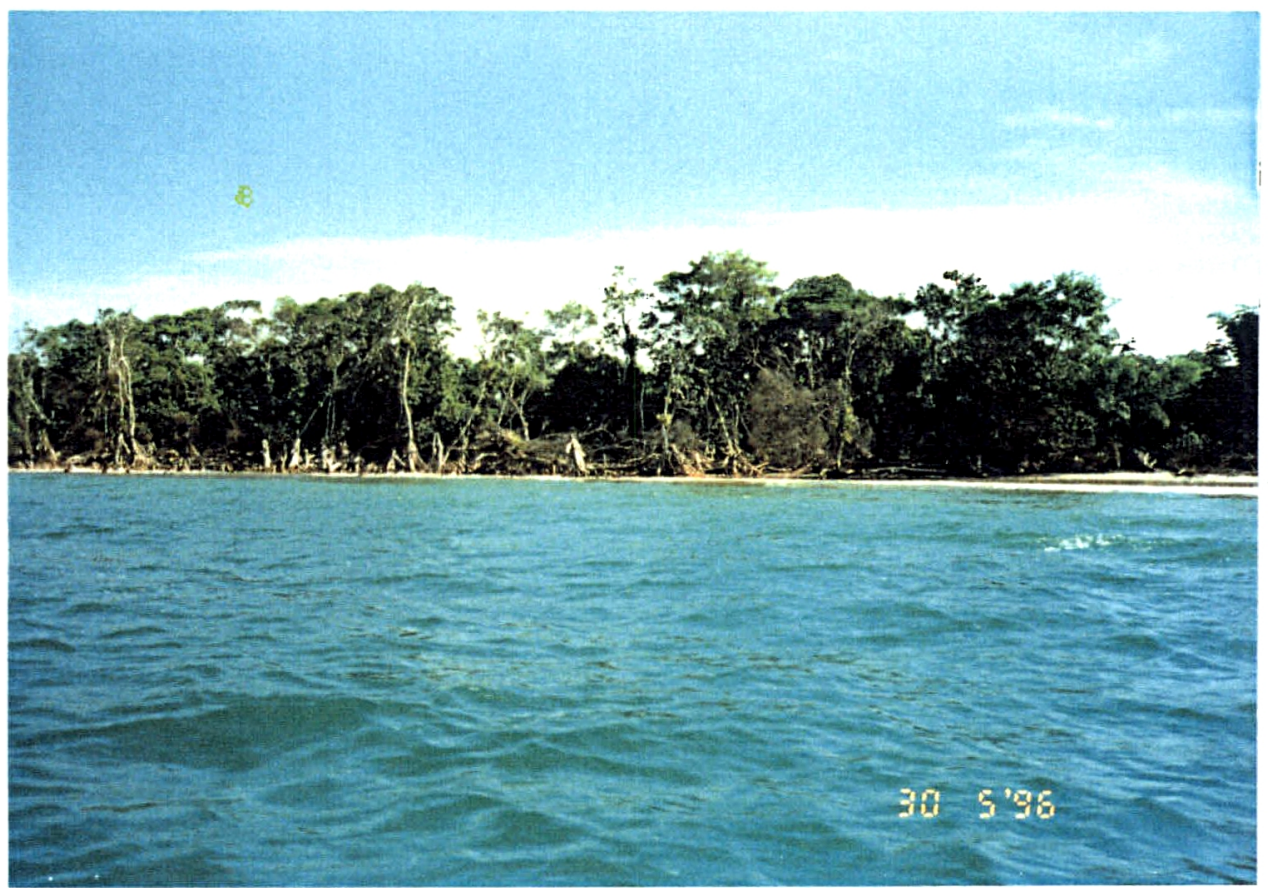

Foto 6.3.3.2. Queda da mata localizada na margem da enseada, oposta à margem onde estão localizados os perfis, indicando a ocorrência de processos erosivos.

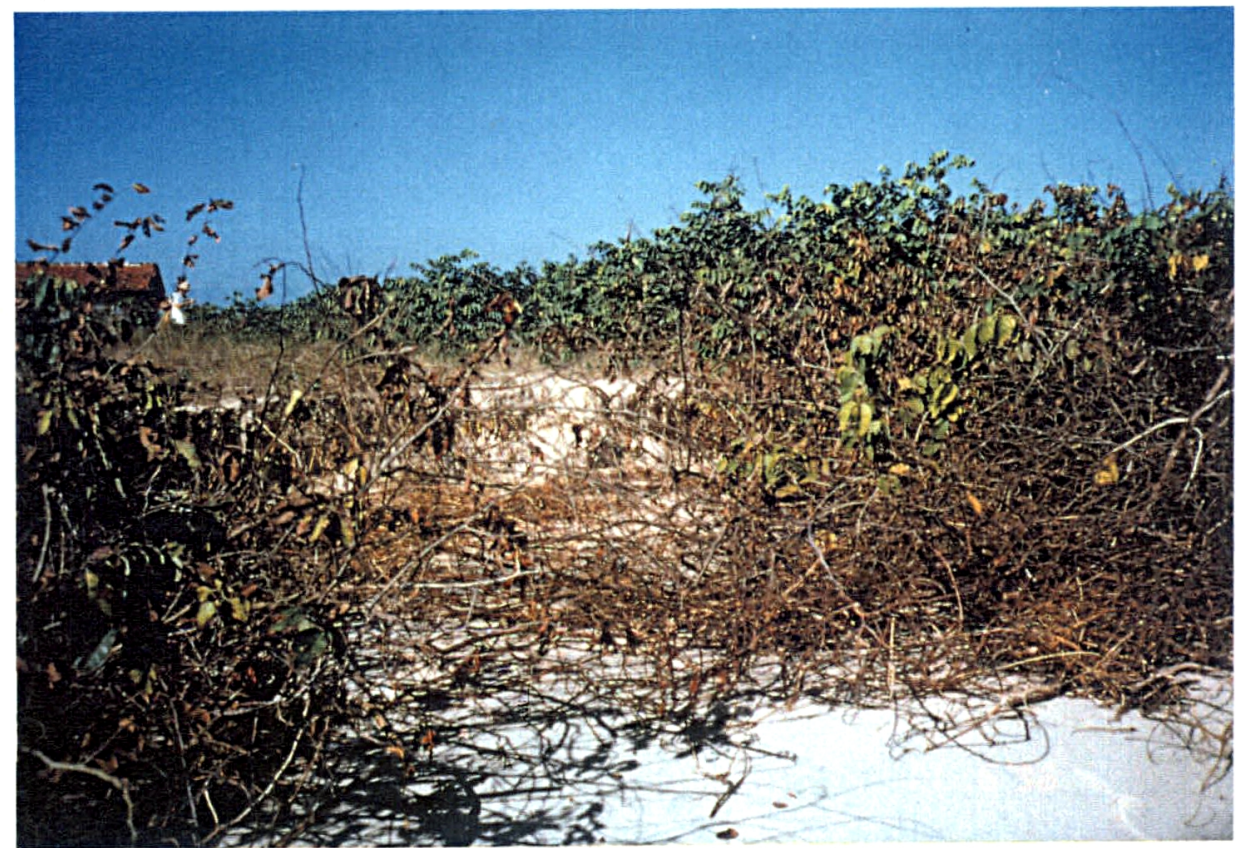

Foto 6.3.5.1. Marcas de erosão do tipo falésias (com aproximadamente $60 \mathrm{~cm}$ de altura) e destruição de parte da vegetação. 


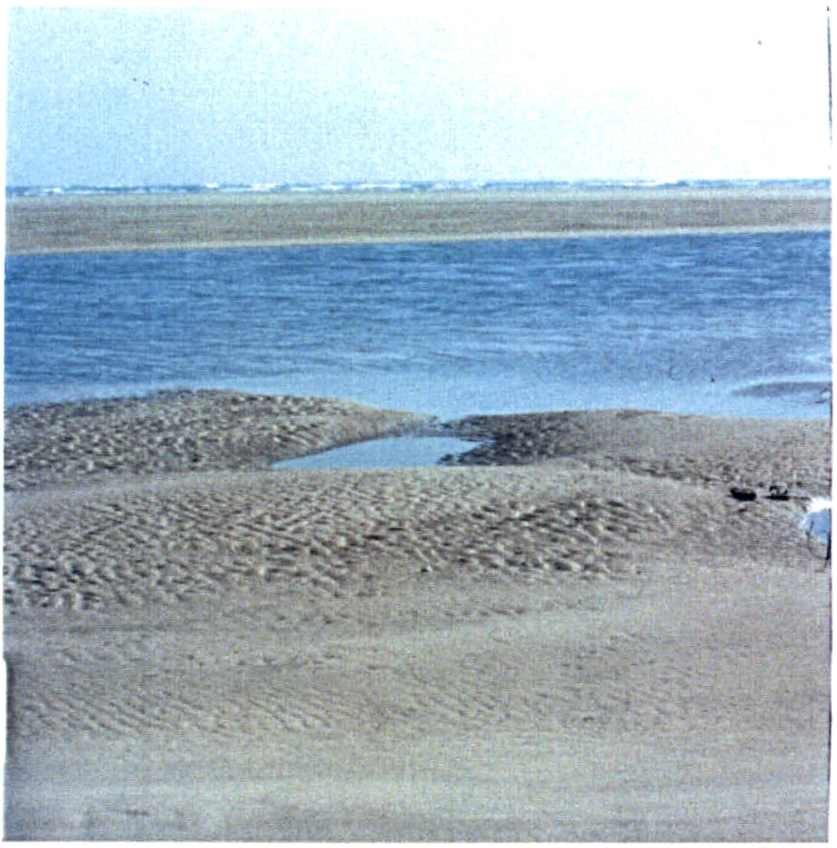

Foto 6.3.6.1. Dunas subaquosas na margem Ilha do Cardoso (Angulo,R.J.; DEGEO-UFPR).

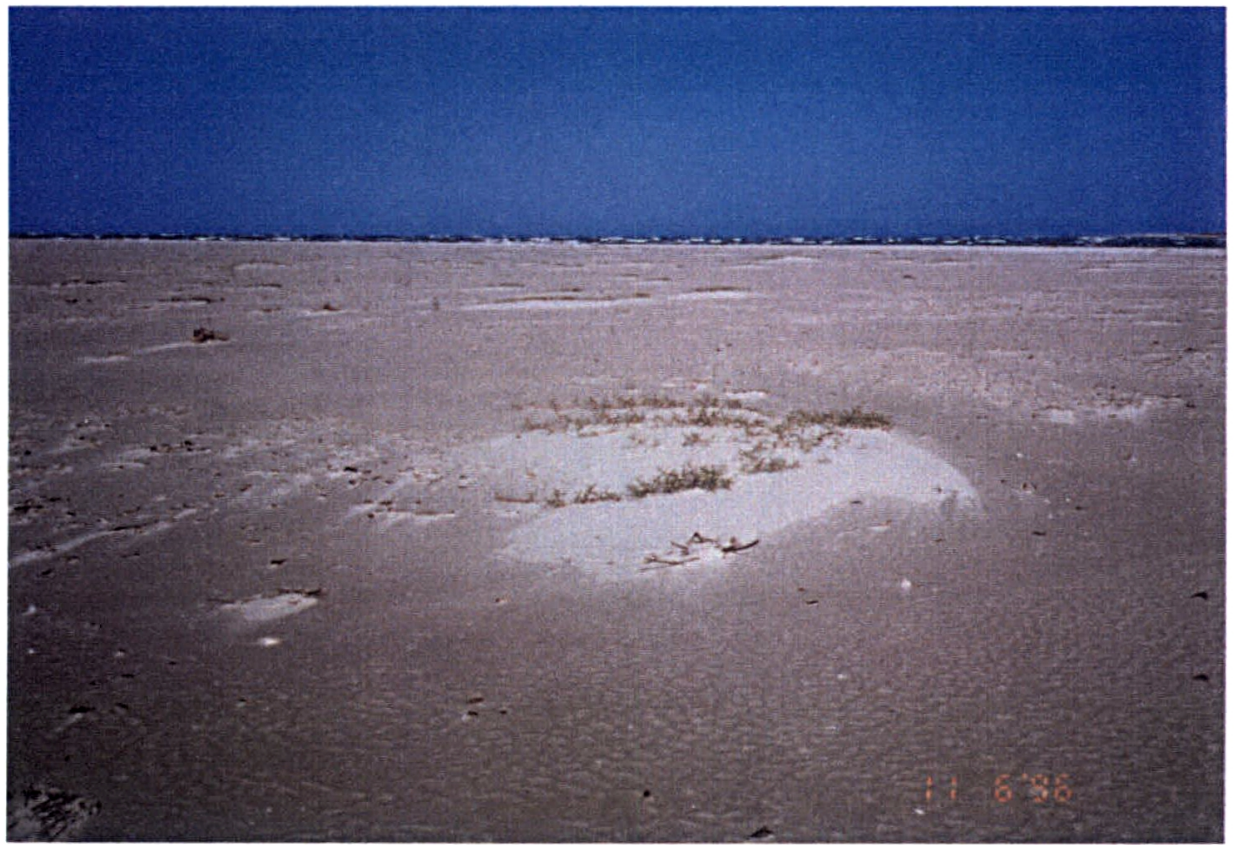

Foto 6.3.6.2. Desenvolvimento de dunas embrionárias (com aproximadamente $10 \mathrm{~cm}$ de altura), a partir de tufos de vegetação esparsa. 


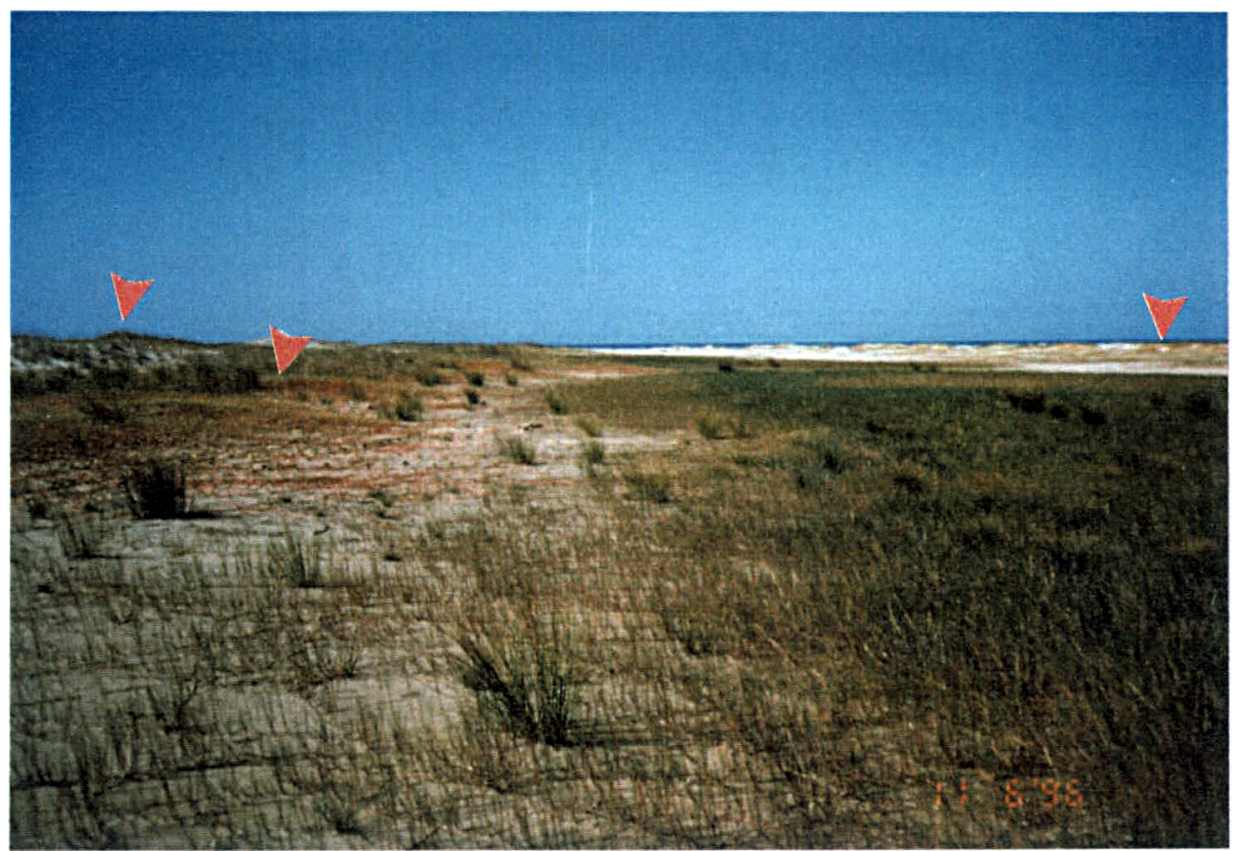

Foto 6.3.7.1. Sequéncia de cordões dunares na margem Ilha do Cardoso; do primeiro ao terceiro, da esquerda para a direita.

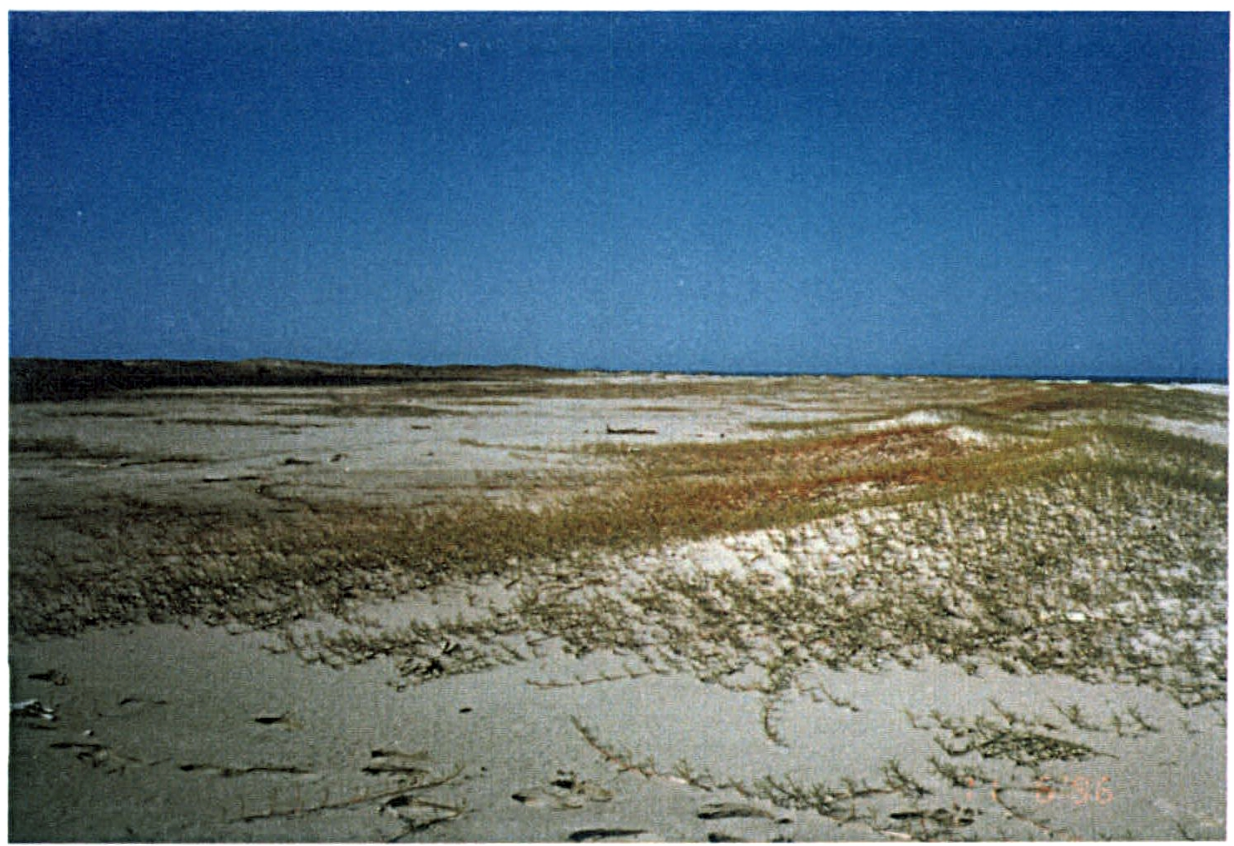

Foto 6.3.7.2. Detalhe do terceiro cordão dunar, na margem Ilha do Superagüi. 


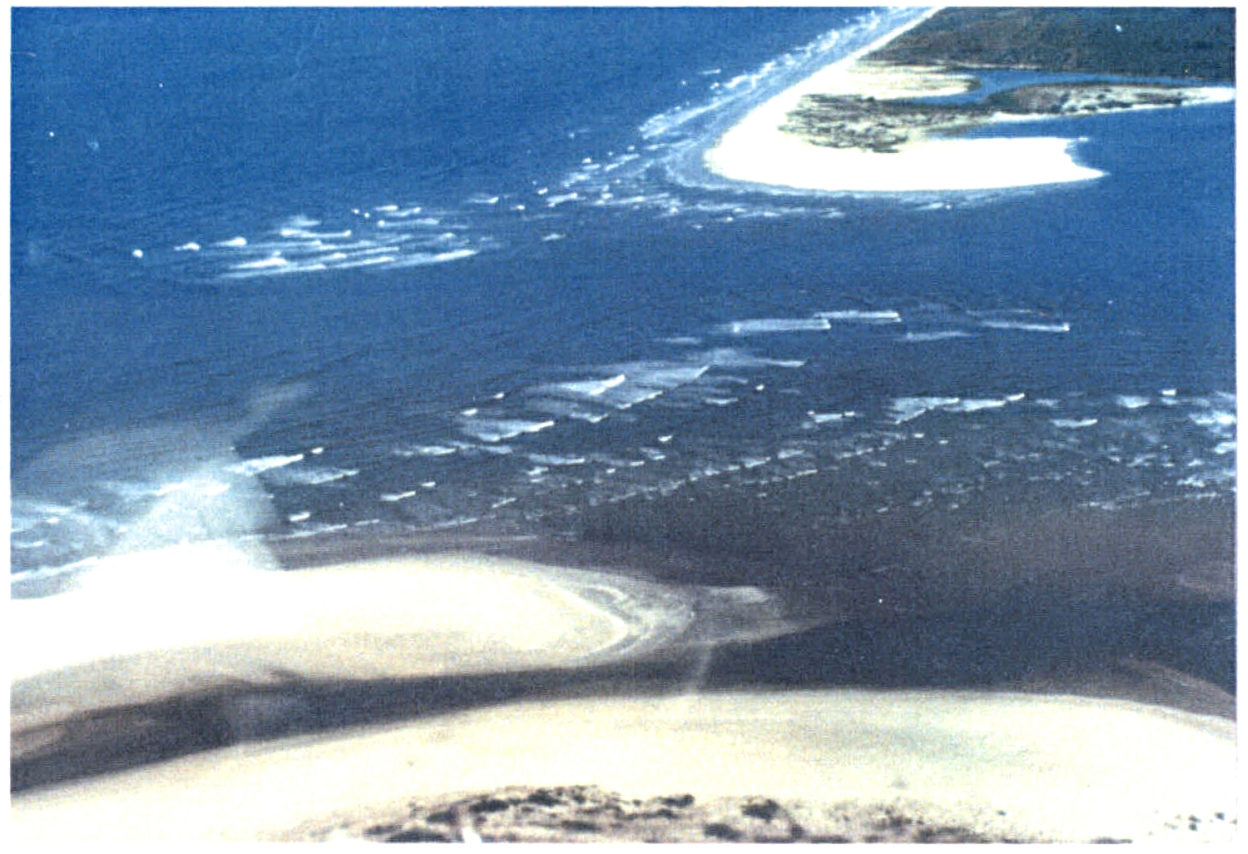

Foto 6.4.1. Vista aérea da Barra do Ararapira em abril de 1992. Acima, observa-se a margem Ilha do Superagüi e, embaixo, a margem Ilha do Cardoso. Notar nesta margem, a presença de bancos arenosos submersos, visíveis pelo padrão de arrebentação das ondas, relacionados com o delta de maré enchente. (Angulo, R.J.; DEGEO-UFPR)

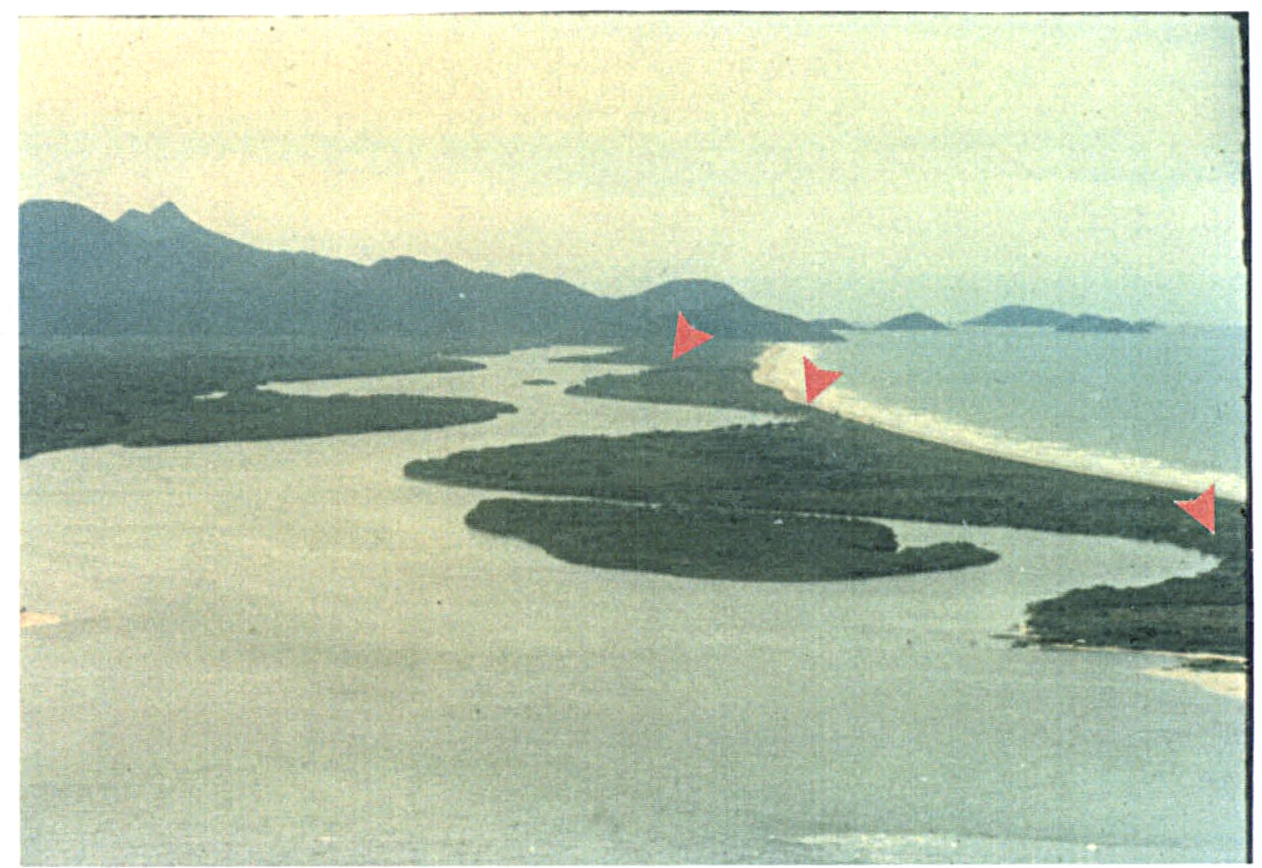

Foto 6.5.1. Vista aérea dos três estreitos no esporão do Ararapira em abril de 1992 (Angulo,R.J; DEGEO-UFPR) 
Foto 6.5.2. Vista aérea da porção mais estreita do esporão do

Ararapira, em julho de 1994

(Angulo,R.J.; DEGEO-UFPR).

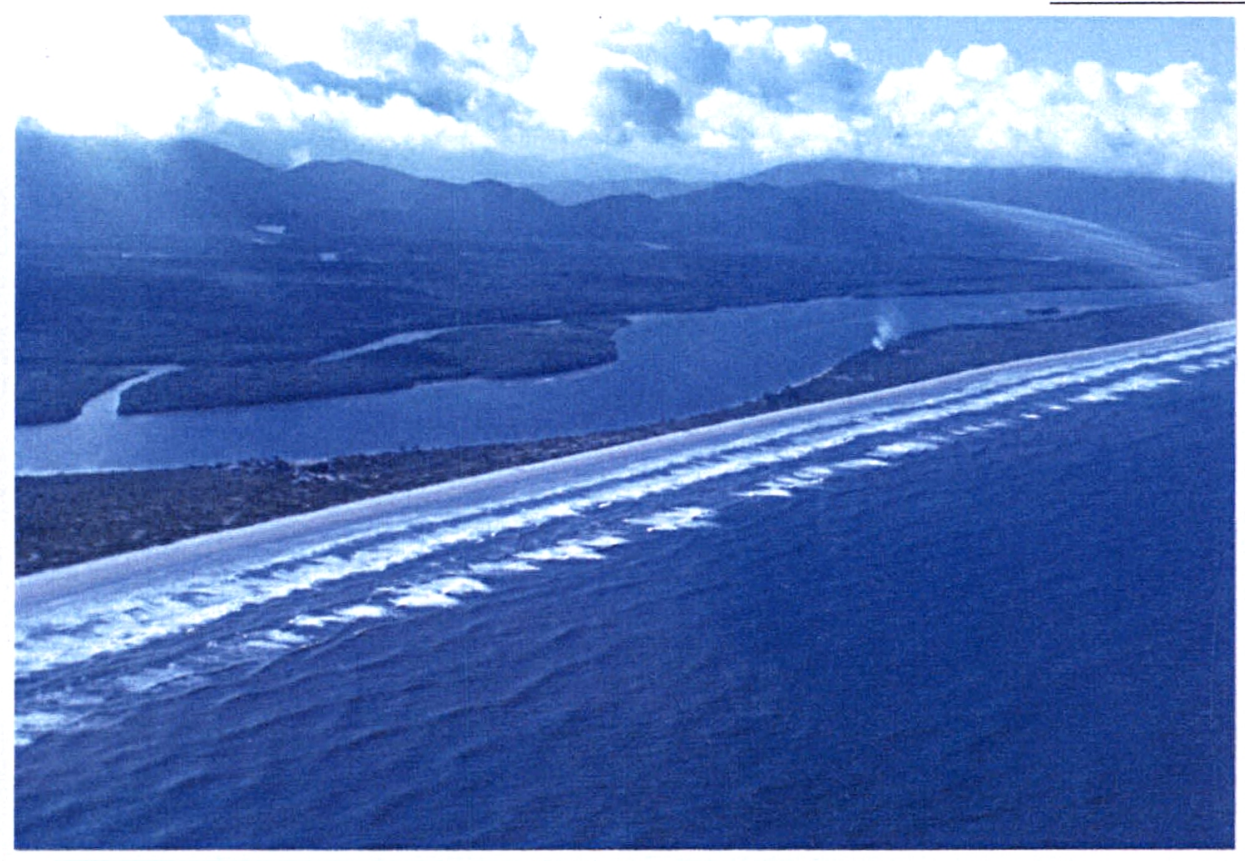

Foto 6.5.3. Falésia existente na margem do corpo lagunar do Ararapira.

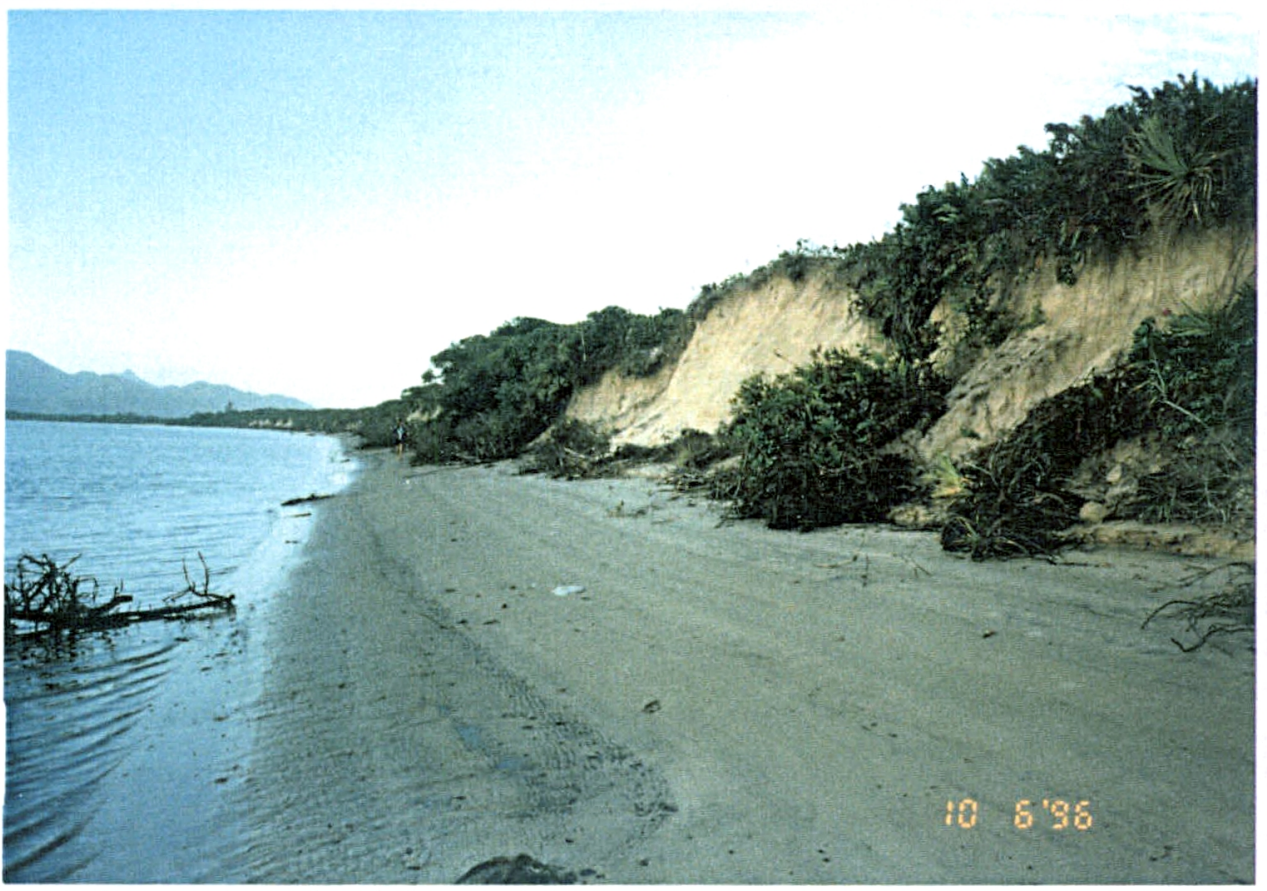

Foto 6.5.4

Desembocadura do canal do Varadouro no corpo lagunar do Ararapira, próximo ao estreito do ponto 4

(Fig.6.3.1), em julho de 1994 (Angulo,R.J.; DEGEOUFPR).

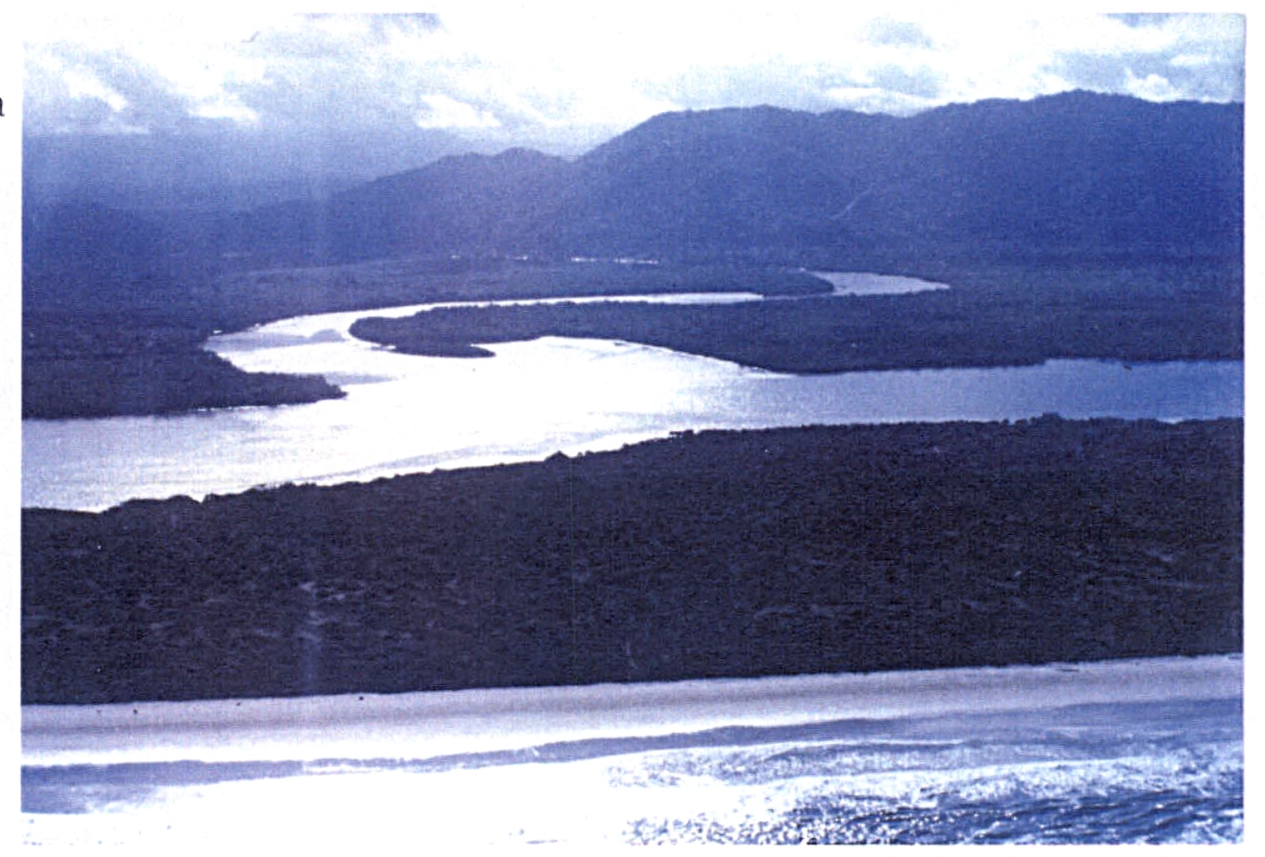

